\title{
Bridging the Gulf, Taking the Risk: An Exploration of "Relationships" in Katherine Mansfield's 'Juliet', 'Brave Love', and 'Prelude'
}

\author{
Jeannie Beauchamp
}

A thesis submitted to Victoria University of Wellington in 2007 in fulfilment of the requirements for the degree of Master of Arts in English.

"But if the Flood, the sky, the rainbow, or what Blake beautifully calls the bounding outline, be removed and if, further, no one thing is to be related to another thing, we do not see what is to prevent the whole of mankind turning author [...] It is not difficult. There is no gulf to be bridged, no risk to be taken."

Katherine Mansfield, June 20 1919, Novels and Novelists, page 40 


\section{Contents}

$\begin{array}{ll}\text { Acknowledgments } & \text { iii }\end{array}$

$\begin{array}{ll}\text { Abstract } & 1\end{array}$

Introduction $\quad 2$

Chapter One: 'Juliet' and 'Brave Love'

$\begin{array}{ll}\text { 'In the Botanical Gardens' } & 17\end{array}$

'Juliet' 21

The irony of unreliable perceptions 25

Setting-derived images $\quad 28$

Parallel scenes $\quad 30$

Allusions 33

'Brave Love' 39

Ironies of impossible choice and unreliable identity 42

Allusions $\quad 45$

Setting-derived images $\quad 59$

Parallels in the final sections $\quad 63$

$\begin{array}{ll}\text { Chapter Two: 'Prelude’ } & 68\end{array}$

$\begin{array}{ll}\text { Perceptions and questions } & 74\end{array}$

Sections I to VII: Subversions of status $\quad 76$

$\begin{array}{ll}\text { Section I } & 77\end{array}$

$\begin{array}{ll}\text { Section II } & 78\end{array}$

$\begin{array}{ll}\text { Section III } & 80\end{array}$

Section IV $\quad 82$

Section V $\quad 84$

Section VI $\quad 86$

$\begin{array}{ll}\text { Section VII } & 96\end{array}$

Sections VIII to XI: “This whole process of becoming the duck” 95

Section VIII 96

Section IX 100

$\begin{array}{ll}\text { Section X } & 105\end{array}$

$\begin{array}{ll}\text { Section XI } & 107\end{array}$

Section XI continued: “One mysterious movement” 108

Section VII: The buried self 116

$\begin{array}{ll}\text { Conclusion } & 125\end{array}$

$\begin{array}{ll}\text { Bibliography } & 126\end{array}$

Appendices: Texts of 'In the Botanical Gardens', 'Juliet', and 'Brave Love' 


\section{Acknowledgments}

I would like to thank my supervisor, Harry Ricketts, for his help, patience, and encouragement during the long labour of this delivery; my husband, Warwick Beauchamp, for his complete and caring support throughout; and everyone else who has asked and listened about this work.

I would also like to thank Margaret Scott, who by introducing me to the Journal of Katherine Mansfield in 1969 started me on this adventure; and whose scholarship via her publications has been continually appreciated en route.

The inclusion of the three texts in the appendices, which was requested by the examiners, is by permission of Oxford University Press, publishers of Katherine Mansfield: New Zealand Stories (for 'In the Botanical Gardens') and Dunmore Press, current publishers of The Katherine Mansfield Notebooks (for 'Juliet' and 'Brave Love').

This thesis is copyright (C) Jeannie Beauchamp 2007 except for the primary and secondary material quoted in and/or accompanying it. 


\section{Abstract}

The introduction of this thesis examines Katherine Mansfield's belief that elements of a fictional work should be "related". ${ }^{1}$ Passages in her literary reviews, journals, and letters state or imply her conviction that such related elements demonstrate the thinking, exploring author's control of the text and express the author's ideas and vision. The introduction also suggests that Mansfield's actual "relationship” methods (as shown in the examined texts) are typical of modernist practice.

The thesis then explores such methods in three of Mansfield's earlier episodic fictions: 'Juliet’ (written 1906-1907), 'Brave Love’ (completed early 1915); and 'Prelude' (written 1915 to 1917). Chapter one introduces the "relationship” methods by a reading of the 1907 vignette 'In the Botanical Gardens'; it then explores the techniques used in 'Juliet' and 'Brave Love', finding some similarity in the approaches. Chapter two is a section-by-section reading of 'Prelude', based on developments of some techniques established in chapter one.

The thesis's primary focus on each work's ways of relating textual elements continues an approach begun by the New Critics but without their tendency to single out a main character, central symbol, and fixed meaning. Here, the argument recognises critical discussions highlighting the binary and the fluid in Mansfield's works and the works' alignment with both expressionism and impressionism.

The resulting readings of the three works demonstrate Mansfield's increasingly skilful techniques of "bridging the gulf” between disparate aspects of experience to achieve the modernist aim of variety and unity. The texts set up standard oppositions (such as conventionality/unconventionality, naivety/cynicism, master/servant, adult/child) and subvert them ironically. Characters on either side are associated with symbols and myths of vulnerability and power to depict how those characters both exercise and are shaped by forces, which may be social, biological, creative, or others more mysterious. These three stories of Mansfield's adolescence and early adulthood implicitly question (given the pervasiveness of such forces) whether free choice and clear vision are possible, which potentials of identity can be realised, and what is the nature of existence itself. These readings demonstrate the achievement of Mansfield's own requirements that fiction should be exploratory: the texts appear in the last resort to be philosophical in intent, "adventures of the soul".

\footnotetext{
${ }^{1}$ References to quotations in this abstract will be provided in the introduction.
} 


\section{Introduction}

This thesis examines 'Juliet', 'Brave Love', and 'Prelude' to demonstrate Katherine Mansfield's developing techniques, through stages of juvenilia, experimentation, and early maturity as a writer, for interrelating the elements of a fictional text. In her nonfiction writing, Mansfield now and again expresses a decided preference for judging fiction by the extent to which its parts are "related". ${ }^{2}$ Her literary criticism gives strongly argued reasons for doing so; the letters and journals give no such complete statements but refer in passing to similar and associated concepts. This introduction explores Mansfield's views about the "related” in fiction and visual art, sketches a possible philosophical background to them, examines recent critical reaction to those views, and outlines the extent to which commentators have used those views in analysing Mansfield's work.

As Alpers has mentioned in connection with the one reference by Mansfield that he knew of to her use of symbols, Mansfield was secretive about the details of her technique in fiction writing ("She had an almost Polynesian reluctance to refer directly to the penetralium of mystery”). ${ }^{3}$ In the period in which she created the three works listed above (1906 to 1917), her writing includes no obvious specific references to the concept of “relationships" in fiction. Mansfield's nearest approach to expressing such a concept during that period is in an often-quoted letter to Ottoline Morrell (15 August 1917), in which Mansfield suggests an approach to writing a fiction based on the garden at Garsington. (Alpers has convincingly argued that a similar letter to Virginia Woolf formed the inspiration for Woolf's sketch 'Kew Gardens’. ${ }^{4}$ ) Typically ambiguously for Mansfield when discussing technique, her use of the word "related" in the following extract could refer both to the personal relationships of the characters and to the technique of linking them to the background:

There would be people walking in the garden - several pairs of people - their conversation their slow pacing - their glances as they pass one another - the pauses as the flowers "come in" as it were - as a bright dazzle, an exquisite haunting scent, a shape so formal and fine, so much a "flower of the mind" that he who looks at it is really is tempted for one bewildering moment to stoop \& touch and make sure. The "pairs" of people must be very different and there must be a slight touch of enchantment - some of them seeming so

${ }^{2}$ As shown below, Mansfield tended to use the participle "related" in such comments; she used the noun "relationships" only once in extant texts, but significantly. The phrase "in relation", also used by Mansfield, is not demonstrated here.

${ }^{3}$ Antony Alpers, The Life of Katherine Mansfield (London: Jonathan Cape, 1980), p. 354.

${ }^{4}$ Alpers, pp. 250-252. 
extraordinarily "odd" and separate from the flowers, but others quite related and at ease. A kind of, musically speaking - conversation set to flowers. ${ }^{5}$

The characters are related to each other in that all are in sets of pairs, and they differ in their degree of separation from or relatedness to the background of flowers as well as in their degree of relationship with one another. The "flower of the mind" could mean the writer's vision and/or that of the owners of the garden; and "he who looks at it” could be the reader and/or a character in the fiction. Finally the flowers are to act as a frame for the whole or as a musical accompaniment to which the conversation is "set".

Mansfield was more explicit about the concept of "relationships" in the post'Prelude' years, in which she used it as a standard of quality in literary and visual works. That she used the concept visually is clear from responses to artworks by J.D. Fergusson, Dorothy Brett, and Richard Murry: here, positive and negative reactions were expressed in terms of relatedness, reflection, and recurrence. For example, writing to Brett on 12 September 1921, Mansfield criticises a painting by Brett of three children:

I don't think it comes off as a composition chiefly because of the big child. She seems to me too big, too pale (even tho' I realise you want to get her fairness over) too broad, too much an expanse. She [is] in a different world to the other child and therefore they can't be really related. ${ }^{6}$

A positive response to a painting by J.D. Fergusson, recalled in a letter to him of 24 January 1918 several years after Mansfield saw it, praises the painting's merging of human and non-human elements, as expressed in a commentary by Smith. Mansfield recollects as follows:

I have a vase of roses and buds before me on the table. I had a good look at them last night and your rose picture was vivid before me - I saw it in every curve of these beauties - the blouse like a great petal, the round brooch, the rings of hair like shavings of light. I thought how supremely you had "brought it off". 7

\footnotetext{
${ }^{5}$ Vincent O'Sullivan and Margaret Scott, eds, The Collected Letters of Katherine Mansfield, vol.1 (Oxford: Clarendon Press, 1984), p. 325. Hereafter cited as KM Letters (O and S), vol. 1, 2 (1987), 3 (1993), or 4 (1996). Note that in quotations from Mansfield, all ellipses not Mansfield's own will be bracketed.

${ }^{6}$ KM Letters (O and S), vol. 4, p. 277.

${ }^{7}$ KM Letters (O and S), vol.2, p. 35.
} 
Angela Smith's comment on Mansfield's reaction brings out the painting's repetitions and its merging of flowers and subject and links that reaction to the philosophy of Bergson (briefly referred to later in this introduction):

The repeated heart shapes in the painting, the patterned suggestion that the subject is flowering and that the flowers are feminine ... have elicited the intuitive recognition in Mansfield that Bergson requires of dynamic art. ${ }^{8}$

A final example is a diary entry dated 25.IV.1918, which describes how recurring accents of colour in Fergusson's studio produce a synaesthetic appreciation:

[I]n the white bookcases the books fly up and down in scales of colour, with pink and lilac notes recurring until nothing remains but them, sounding over and over. ${ }^{9}$

This response is similar to the process of repetition described by Bateson and Shahevitch with reference to techniques used in Mansfield's 'The Fly' (1962):

The repetition of any phrase or construction will give it, if repeated often enough, a new semantic dimension. A similar process occurs if some parallelism establishes itself between the separate episodes in a narrative or drama. Gradually an unstated generality superimposes itself on the sequence of particulars. A narrative pattern emerges. ${ }^{10}$

Comments by Mansfield about "related” elements in literary works become more explicit in some of her reviews (from April 1919 to December 1920) of newly published novels. The fact that she reviewed novels does not mean that her standards should not relate to her own short stories. At least once in her reviews, Mansfield explicitly widened their terms of reference to include other kinds of writing than novels: "Can we of this age go on being content with stories and sketches and impressions and novels which are less than adventures of the soul?" 11

In Mansfield's reviews, the two passages that discuss the concept of relatedness with most reference to other aspects of her aesthetic are in items dated 30 May and 20 June 1919. The first of these finds Vita Sackville-West's novel Heritage lacking a "central point of significance" to which, it is implied, the "endeavours and ${ }^{8}$ Angela Smith, Katherine Mansfield: A Literary Life (Hampshire, UK and New York: Palgrave, 2000), p. 14. Hereafter cited as Smith, A Literary Life.

${ }^{9}$ Margaret Scott, ed., The Katherine Mansfield Notebooks, vol. 2 (Canterbury: Lincoln University Press; and Wellington: Daphne Brasell Associates, 1997), p. 133. Hereafter cited as KM Notebooks, vol. 1 or 2.

${ }^{10}$ F.W. Bateson and B. Shahevitch, 'Katherine Mansfield's “The Fly”: A Critical Exercise’, Essays in Criticism, vol. 12 (January 1962), pp. 39-53, rpt in Jan Pilditch, ed., The Critical Response to Katherine Mansfield (Westport, Connecticut; London: Greenwood Press, 1996), p. 86.

${ }^{11} \mathrm{~J}$. Middleton Murry, ed., Novels and Novelists by Katherine Mansfield (London: Constable, 1930), p. 50. Hereafter cited as Novels and Novelists. 
emotions" of the characters should have been connected. The passage suggests (in the negative terms of this novel's failure) that the related parts of a fictional work should support a sense of the characters' exploration, progression, and discovery (a search in which author and readers are involved) as well as a sense of the author's control:

If we are not to look for facts and events in a novel - and why should we? we must be very sure of finding those central points of significance transferred to the endeavours and emotions of the human beings portrayed [...] There must be the same setting out upon a voyage of discovery [...] There must be given the crisis when the great final attempt is made which succeeds - or does not succeed. Who shall say?

This crisis, then, is the chief of our "central points of significance" and the endeavours and the emotions are stages on our journey towards or away from it. For without it, the form of the novel, as we see it, is lost. Without it, how are we to appreciate the importance of one "spiritual event" rather than another? What is to prevent each being unrelated - complete in itself - if the gradual unfolding in growing, gaining light is not to be followed by one blazing moment?

We may look in vain for such a moment in 'Heritage'. It abounds in points of significance, but there is no central point. After an excellent first chapter - an excellent approach - we almost immediately [begin?] to feel that the author, in dividing her story as she does between two tellers, has let it escape from her control. And as one reads on the feeling becomes more urgent: there is nobody in control. Her fine deliberate style is, as it were, wilfully abused by the two tellers [...] until finally, between them they break the book into pieces [...] each one, if we examine closely, a complete little design in itself. $^{12}$

This example of the "unrelated" in a text suggests that there is no sense of progression or unity in Heritage because the "spiritual events" (possibly the characters' "emotions and endeavours”) have no relative importance, with no culminating “blazing moment” in which the light (of author's, characters', and readers' vision) that has grown from one event to another fully emerges.

The second review passage, this time in regard to Mary Olivier - A Life by May Sinclair, also uses a standard of what should be "related" to assess the novel under review. Against an ideal of characters' relatedness to one another and to a background of mythical inevitability, Mansfield contrasts Sinclair's novel, in which she considers that the elements are separate from one another and from any meaningful background. Mansfield sees the aim of May Sinclair's story as merely to describe each element's effect on an experiencing subject, whereas the aim of the

\footnotetext{
${ }^{12}$ Novels and Novelists, pp. 29-30.
} 
exploring, thinking writer is to "reveal a little of the mystery of life" to the exploring, thinking reader by bridging a gulf and taking a risk:

[T] he difference between the new [i.e., Sinclair's] way of writing and the old way is not a degree of difference but of kind. [Sinclair's] aim, as we understand it, is to represent things and persons as separate, as distinct, as apart as possible. Here, if you like, are the animals set up on the floor, the dove so different from the camel, the sheep so much bigger than the tiger. But where is the Ark? And where, even at the back of the mind, is the Flood, that dark mass of tumbling water which must sooner or later receive them, and float them or drown them? The Ark and the Flood belong to the old order, they are gone. In their place we have the author asking with indefatigable curiosity: "What is the effect of this animal upon me, or this or the other one?"

But if the Flood, the sky, the rainbow, or what Blake beautifully calls the bounding outline, be removed and if, further, no one thing is to be related to another thing, we do not see what is to prevent the whole of mankind turning author. Why should writers exist any longer as a class apart if their task ends with a minute description of a big or a little thing? If this is the beall and end-all of literature why should not every man, woman and child write an autobiography and so provide reading matter for the ages? It is not difficult. There is no gulf to be bridged, no risk to be taken. If you do not throw your Papa and your Mama against the heavens before beginning to write about them, his whiskers and her funny little nose will be quite important enough to write about [...]

But the great writers of the past [...] have been seekers, explorers, thinkers. It has been their aim to reveal a little of the mystery of life. Can one think for one moment of the mystery of life when one is at the mercy of surface impressions? [...] Is it not the great abiding satisfaction of a work of art that the writer was master of the situation when he wrote it and at the mercy of nothing less mysterious than a greater work of art? ${ }^{13}$

The unspecified gulf and the risk to the author of failing to bridge it can be read here as the gap between characters and background, between "your Papa and your Mama” and "the heavens"; but whether these "heavens" are to suggest a mythical or natural background is left unsaid. (However, Mansfield's many references to the myth of Noah's ark above suggest that a mythical background is not excluded.)

Mansfield's characteristic equivocation has led to such passages on relationship being interpreted differently by the few commentators who have engaged directly with them. Eileen Baldeshwiler interprets a similar statement of Mansfield's about "linking [the character's] mind to the larger whole"14 (quoted more fully below)

\footnotetext{
${ }^{13}$ Novels and Novelists, pp. 41-42

${ }_{14}$ Novels and Novelists, p. 52.
} 
as being about "detail ... responsible to a larger structure or a deeper significance”, 15 so that the "larger whole" could mean either the work itself or a meaning suggested by that work. In his chapter The Artist as Critic, Marvin Magalaner interprets such statements by Mansfield to mean that fictional characters should be related to "the broader spectrum, this continuity, the universe, history, in short, to whatever appropriate universal applies”. ${ }^{16}$ Finally, Clare Hanson gives the passage from pages 41-42 quoted above an ethical and aesthetic emphasis, as follows:

... KM uses Blake's image of the "bounding line" [sic] to suggest that widest possible ethical and aesthetic perspective which, she felt, should distinguish the great novel ... The suggestion that the world of art and the world of "fact" are analogous and conterminous ... reflects KM's very modernist feeling for the unreality and insubstantiality of any external world conceived of as existing outside the (involuntarily) creative mind of man. ${ }^{17}$

Here Hanson implies (possibly with reference to the sentence about the writer "at the mercy of ... a greater work of art") that the "gulf to be bridged” is crossed by locating both characters and background in aesthetic and ethical dimensions of the mind. Hanson's statement that Mansfield did not recognise the external world beyond its realisation by the human mind appears to overlook Mansfield's always deeply felt commitment to the external world and possibly reflects Hanson's claim that as a symbolist, Mansfield was using concrete images to express "abstract states of mind or feeling” (page 9). The answer, instead, could be that Mansfield's drive as a writer was, in "bridging the gulf", to add to, not detract from, her subject. For example, in her often-quoted letter to Brett about the technique used in 'Prelude' (11 October 1917), Mansfield half-jokingly expresses bridging the gap between art and world in terms of the artist's first becoming the objects or characters to be depicted and then metaphorically rebirthing them (possibly in ways expressing the artist's vision):

When I pass the apple stalls I cannot help stopping and staring until I feel that I, myself, am changing into an apple, too - and that at any moment I may produce an apple, miraculously, out of my own being like the conjurer produces the egg [...] When I write about ducks I swear that I am a white duck with a round eye, floating in a pond fringed with yellow blobs and taking an occasional dart at the other duck with the round eye, which floats upside down beneath me. In fact this whole process of becoming the duck (what Lawrence would, perhaps, call this "consummation with the duck or the

${ }^{15}$ Eileen Baldeshwiler, 'Katherine Mansfield’s Theory of Fiction', Studies in Short Fiction, vol.7 no.3 (Summer 1970), p. 426.

${ }^{16}$ Marvin Magalaner, The Fiction of Katherine Mansfield (Carbondale and Edwardsville: Southern Illinois University Press; Feffer and Simons, 1971), p. 12.

${ }^{17}$ Clare Hanson, ed., The Critical Writings of Katherine Mansfield (New York: St Martin's Press, 1987), pp. 14-15. 
apple”) is so thrilling that I can hardly breathe, only to think about it. For although that is as far as most people can get, it is really only the 'prelude'. There follows the moment when you are more duck, more apple or more Natasha than any of these objects could ever possibly be, and so you create them anew [...] But that is why I believe in technique, too (you asked me if I did). I do, just because I don't see how art is going to make that divine spring into the bounding outlines of things if it hasn't passed through the process of trying to become these things before recreating them. ${ }^{18}$

Specifically using the central duck image in 'Prelude', this passage suggests how the author rebirths the depicted world so that its objects are "more ... than any of these objects could ever possibly be", that is, perhaps, recreated with significance specific to the particular work. So (in terms from the following quotation), the objects of nature can be "passionately realized” to suggest the mind's awareness of larger realities - that is, to link it, as Baldeshwiler has it, to "a larger structure or a deeper significance": ${ }^{19}$

Then, indeed, as in the stories of Tchehov, we should become aware of the rain pattering on the roof all night long, of the languid, feverish wind, of the moonlit orchard or the first snow, passionately realized, not indeed as analogous to a state of mind, but as linking that mind to the larger whole. ${ }^{20}$

Outside of her reviews, Mansfield seldom referred to the concept of fictional relationships in writing. Her sole use of the word "relationships" in notes about her own writing, in a diary entry of 23 July 1921, is ambiguous, since it could refer to (and has been read by others as meaning) the personal relationships of the characters:

I worked at ['An Ideal Family'] hard enough, God knows \& yet I feel I didn't get the deepest truth out of the idea, even once. What is this feeling? I feel again that this kind of knowledge is too easy for me; it's even a kind of trickery [...] Once I have written 2 more I shall tackle something different - a long story - At the Bay with more difficult relationships. That's the whole problem.

From this diary entry, it looks as if Mansfield's dissatisfaction with 'An Ideal Family' involved a problem with "relationships" - a problem she intended to address in "At the Bay' (which followed in August-September 1921); and as if using “relationships” in this sense involved "getting the deepest truth out of the idea". Implying this

${ }^{18}$ KM Letters (O and S), vol.1, p. 330.

19 Baldeshwiler, p. 426.

${ }^{20}$ from a review of The Escape of Sir William Heans by William Hay (July 18 1919), Novels and Novelists, p. 51.

${ }^{21}$ KM Notebooks, vol. 2, p. 279 
“deepest truth" in her work could be a similar aim to the "larger whole”22 suggested in Mansfield's review above. Mansfield's underlining of "relationships" in this passage suggests the central significance the term had for her.

Mansfield’s opinions about “relationships” in fiction appear to involve artistic vision as well as ideas. For example, a diary entry immediately following one dated 15 December 1919 describes how, in fever, Mansfield could “call up” people and scenes from her past. The extract below suggests that seeing Doctor Sorapure "in relation” made him appear "marvellously beautiful” by connecting his visual appearance with the image of his needle and syringe, which perhaps suggested the scientific viewpoint, and wider dimensions of life and death, to Mansfield:

But when I so summon [Doctor Sorapure] and see him “in relation” he is marvellously beautiful. There again he comes to every tiny detail to the shape of his thumbs, to looking over his glasses, his lips as he writes \& particularly in all connected with putting the needle into a syringe - I relive all this at will. $^{23}$

In the diary extract above, Mansfield was probably quoting her own phrase "in relation” from a review, published a few days before on December 12 1919, in which she stated that the "living" fictional characters of Louis Couperus "are seen ever, and always in relation to life - not to a part of life, not to a set of society, but to the bounding horizon, life”. ${ }^{24}$ She possibly felt that her vision of Doctor Sorapure as "marvellously beautiful" was equally "in relation to life".

Similarly, her conflicting reactions to James Joyce’s Ulysses include the statement to Dorothy Brett (1 May 1922) that techniques associating the characters with different dimensions transmit how the characters are "seen”, presumably by the author:

... ([A]lthough I don't approve of what he's done) I do think Marian Bloom and Bloom are superbly seen at times. Marian is the complete complete female. There's no denying it. But one has to remember she's also Penelope, she is also the night and the day, she is also an image of the teeming earth, rolling round and round. And so on and so on. ${ }^{25}$

The multidimensional characterisation described here has a surprising similarity to that used in Mansfield’s early experiment 'Brave Love'.

\footnotetext{
${ }^{22}$ Novels and Novelists, p. 51.

${ }^{23}$ KM Notebooks, vol. 2, p. 181-182.

${ }_{24}$ Novels and Novelists, p. 126.

25 J. Middleton Murry, ed., The Letters of Katherine Mansfield, vol. 2 (London: Constable, 1928), p.

208. Hereafter cited as KM Letters (Murry).
} 
Many commentators have made links between Mansfield's techniques and a philosophical/cultural background. If it is applied to her own work, Mansfield's emphasis on "linking [the fictional character's] mind to the larger whole" might contradict commentaries such as those based on literary impressionism, which state, for example, that:

Mansfield avoided figures that would draw on spiritual or supernatural planes for their meaning. No outward systems of mythology, or supernatural or Symbolist planes are referred to. Mansfield's images momentarily refer inward to meanings established by a fragmentary context, to a 'Stimmung' evoked by nature, colour, and objects, to the personal values underlying the thoughts and feelings of the major characters. ${ }^{26}$

On the other hand, the reference to "a larger whole" is more likely to align with [?] the post-impressionist approach to Mansfield's fiction taken by Angela Smith, who contrasts impressionist and post-impressionist works as follows:

Impressionism privileges surface appearances and the viewer's eye, whereas Post-Impressionism, and literary modernism in at least some of its manifestations, are concerned with the profound self, and with deep structures. $^{27}$

Smith links post-impressionist art, and Mansfield's work, to the philosophy of Bergson ("a major intellectual influence on Fergusson and Murry at the time that they met in Paris in $191{ }^{» 28}$ ). According to Smith, Bergson suggested that we have two selves, one that is mechanistic and lives for and on the surface, and the other that "leads us to grasp our inner states as living things, constantly becoming, as states not amenable to measure, which permeate one another”. ${ }^{29}$ In fact, Smith seems to imply a combination of impressionist and post-impressionist approaches in her view of Mansfield's work using repetition to show deep structures as well as a surface:

Mansfield's intensification ... penetrates beneath the outward surface and rhythmically disengages strange, sometimes recurrent, images such as the bleached landscape and the figures whitened by pumice dust in 'The Woman at the Store', or the reiterated Fauvist insistence on the colour red in 'Ole Underwood' ...

\footnotetext{
${ }^{26}$ Julia van Gunsteren, Katherine Mansfield and Literary Impressionism (Amsterdam-Atlanta: Editions Rodopi, 1991), p. 182

${ }^{27}$ Smith, A Literary Life, p.11.

${ }^{28}$ Smith, A Literary Life, p.10.

${ }^{29}$ Henri Bergson, Time and Free Will (1889, first English version 1910), quoted in Smith, A Literary Life, p. 10.

${ }^{30}$ Angela Smith, 'Katherine Mansfield and Rhythm', Journal of New Zealand Literature, vol. 21 (2003), p. 105.
} 
Ken Arvidson supports Smith’s connection between Bergson’s philosophy and Mansfield’s “relationship” technique:

[Mansfield] also practised one of the most central principles intended by Bergson's concept of "rhythm”, the repetition from part to part, almost from paragraph to paragraph, of a central idea or motif, allowing it to pervade an entire work. ${ }^{31}$

Bergson's view of the “deep self”, “constantly becoming”, is similar to Walter Pater's relativistic view of the self as expressed in his essay 'Coleridge's Writings':

Modern thought is distinguished from ancient by its cultivation of the "relative" spirit in place of the "absolute" ... To the modern spirit nothing is or can be rightly known except relatively under conditions ... So the idea of "the relative" has been fecundated in modern times by the influences of the sciences of observation. These sciences reveal types of life evanescing into each other by inexpressible refinements of change. Things pass into their opposites by accumulation of indefinable quantities ... [T]he relative spirit has invaded moral philosophy from the ground of the inductive sciences. There it has started a new analysis of the relations of body and mind, good and evil, freedom and necessity ... It seems as if the most opposite statements about [man] were alike true; he is so receptive, all the influences of the world and of society ceaselessly playing upon him, so that every hour in his life is unique, changed altogether by a stray word, or glance, or touch. The truth of these relations experience gives us ... ${ }^{32}$

So Pater (long accepted as an early main influence on Mansfield's thinking) promotes "a new analysis of the relations" between opposites: "body and mind, good and evil, freedom and necessity”. The resulting view of the self as an interplay of opposites is confirmed by O’Sullivan's quotation from Pater about “that strange weaving and unweaving of ourselves” 33 mentioned later in this thesis. The philosophical backgrounds of Pater and Bergson support Mansfield’s major “relationship” techniques of merging opposites and of repeating images that reveal contrasting yet linked aspects of experience or the self. This thesis, however, argues less for Mansfield's being influenced by Bergson and Pater in particular than for her questioning outlook being philosophical in general. Mansfield's interest in philosophy appears to have been ongoing, as her references to various philosophers in

\footnotetext{
${ }^{31}$ Ken Arvidson, 'Katherine Mansfield and a Way of Seeing', in Katherine Mansfield - Stories and Pictures, Department of English, The University of Waikato Occasional Paper no. 2, 2003, p. 13.

${ }^{32}$ Walter Pater, 'Coleridge’s Writings', Westminster Review (1866), rpt. in Walter Pater: Essays in Literature and Art, ed. Jennifer Uglow (London: Dent; Totowa, N.J.: Rowman and Littlefield, 1973), pp. 1-2.

${ }^{33}$ Walter Pater, The Renaissance, Studies in Art and Poetry (Fontana, 1961), quoted in Vincent O’Sullivan, 'The Magnetic Chain: Notes and Approaches to K.M.', Landfall, vol. 29 no. 2, rpt. in Pilditch, p. 139.
} 
her notebooks (Nietzsche, Kant, Hegel, Vaihinger) and to philosophy itself suggest. For example, recognising the contrasting mocking and philosophic sides of her nature, Mansfield half-jokingly writes to Murry (8 November 1920):

Alone I'm no end of a fillaseafer [philosopher] but once you join me in the middle of my seriousness - my deadly seriousness I see the piece of pink wool I have put on your hair (\& that you don't know is there). ${ }^{34}$

Although commentators have often either acknowledged or used Mansfield's fictional interrelationship techniques in their analyses of her work, no study so far has concentrated entirely on those techniques. The very rich commentaries about Mansfield's fiction that have emerged over recent decades have approached it in various ways, as discussed in more detail at the beginning of chapters one and two of this thesis. When analysing Mansfield's early work, commentators have tended to recognise the binary (emphasis on opposing aspects) and the recurrent but not to consider them in combination; a way of combining the two aspects is demonstrated in this thesis's brief introductory analysis of the vignette 'In the Botanical Gardens' (1908). With reference to Mansfield's mature work as exemplified in 'Prelude' (one of the most discussed items of her fiction), previous commentary has moved through phases relating to romanticism, new criticism, symbolism, psychology, feminism, literary impressionism, post-colonialism, and post-structuralism (or combinations of these). In recent decades, Mansfield criticism can be approximated as dividing into two groups: that in which technique is the more important consideration, and that which uses examination of the text "as ... endorsement for a view that often existed before the reading began”. ${ }^{35}$ In both groups, the choice and interpretation of “relationship” techniques, though resulting in much useful insight, can appear to depend on whether the "relationship" is read as supporting the particular technical approach or ideology involved. In both groups, angles of approach, whether technical or ideological, affect the choice and interpretation of "relationships". So, for example, New Critical commentaries tended to single out a particular symbol and/or character as central and to see associative patterns as leading to fixed meanings. The tendency to arrive at fixed meanings, and the resulting approval or disapproval of characters depending on the commentator's viewpoint, continued ${ }^{34}$ KM Letters (O and S), vol. 4, p. 104.

${ }^{35}$ Vincent O'Sullivan, 'What We Mostly Don't Say about Katherine Mansfield', in Katherine Mansfield's Men: Perspectives from the 2004 Katherine Mansfield Birthplace Lecture Series, ed. Charles Ferrall and Jane Stafford (Wellington: Katherine Mansfield Birthplace Society in association with Steele Roberts Publishers, 2004), p. 98. 
through many successive approaches through the decades. Most recent commentary, though moving away from fixed meanings in its awareness of the binary, of states of becoming or of the liminal, and of the exploratory in Mansfield's work, still tends to overlook possibilities of meaning that would contradict whatever ideology the commentary promotes. So, for example, Angela Smith discusses Mansfield's theme of identity in terms of the 'Prelude' characters' 'wrestling with their gender identities”. ${ }^{36}$ Whatever their angle of approach to Mansfield's work, however, commentators have generally arrived at the consensus that that work is modernist, although they may differ in how they interpret the term.

In this thesis, the "relationships" (within a modernist context) are the primary focus and are used as a net for possibilities of meaning, which often result in matching those arrived at previously by others. However, “possibilities” are the operative word, since a study of "relationships” first and foremost in Mansfield's work demonstrates her commitment to the exploratory, to "reveal[ing] a little of the mystery of life". ${ }^{37}$ Since potentials for "relationship" are endless, attention in this thesis has been limited to those that are most credible in terms of methods such as those possibly first recognised (with regard to Mansfield's fiction) by the New Critics: “narrative pattern[s]" that emerge from "repetition of any phrase or construction" and "parallelism establishe[d] ... between ... separate episodes"; 38 or "sometimes subtle, sometimes blatant patterns of association: ... repetitions of images and symbols in diverse contexts" ${ }^{39}$ Such techniques, as well as allusion to myths and literary texts (also used by Mansfield, as this thesis demonstrates) are characteristic of modernism:

By way of compensation for the weakening of narrative structure and unity, other modes of aesthetic ordering became more prominent [in modern fiction] - such as allusion to or imitation of literary models, or mythical archetypes; or repetition-with-variation of motifs, images, symbols, a technique often called 'rhythm', 'leitmotif', or 'spatial form'. ${ }^{40}$

In his discussion of literary modernism, Abrams describes how T.S. Eliot, in The Waste Land:

\footnotetext{
${ }^{36}$ Angela Smith, Katherine Mansfield and Virginia Woolf: A Public of Two (Oxford: Clarendon Press, 1999), p. 107. Hereafter cited as Smith, KM and VW.

${ }^{37}$ Novels and Novelists, pp. 41-42.

38 Bateson and Shahevitch, p .86.

${ }^{39}$ Magalaner, p. 29.

40 David Lodge, 'The Language of Modernist Fiction: Metaphor and Metonymy', in Modernism 18901930, ed. Malcolm Bradbury and James McFarlane (Harvester Press, 1978), p. 481.
} 
substituted for the traditional coherence of poetic structure a deliberate dislocation of parts, in which very diverse components are related by connections that are left to the reader to discover, or invent. ${ }^{41}$

In this thesis, motifs, together with parallelism, allusion, and echo, are all demonstrated as, in Mansfield's fictions, being used to relate "very diverse components”, resulting in different structures to those on the surface or in a multidimensional view of experience and identity. The fact that some of these structures, especially in Mansfield's early work, involve ancient and modern myths is also characteristic of modernism, as expressed in T.S. Eliot's famous statement in 1923, when discussing James Joyce’s Ulysses, that “Instead of narrative method we may now use the mythical method." 42

Where possible, the "complex of relationships" 43 arrived at will be backed up by Mansfield's own comments. But as Mansfield herself wrote in her diary when reading Shakespeare (January 3 1922): “The Tempest seems to me astonishing this time. When one reads the same play again it never is the same play."44

\footnotetext{
${ }^{41}$ Abrams, p. 167.

${ }^{42}$ T.S. Eliot, quoted in The Oxford Illustrated History of English Literature, ed. Pat Rogers (Oxford and New York: Oxford University Press, 1987), p. 425.

43 "[Modernist] [a]rtists, poets and writers ... saw [the world] as a complex of relationships individual to them and of which their own perception was the co-ordinator.” Roy Strong, The Spirit of Britain: A Narrative History of the Arts (London: Pimlico, 2000), p. 605.

${ }^{44}$ KM Notebooks, vol. 2, p. 313.
} 


\section{Chapter One: 'Juliet' and 'Brave Love'}

The introduction to this thesis has discussed Mansfield's conviction, demonstrated most clearly in her literary criticism, that textual interrelationships are an essential component of fiction. The introduction has also suggested that Mansfield's use of such “relationships” (as she appears to have called them - her ambiguous and qualified language makes a more definite statement impossible) was an integral part of her modernist approach to fiction. This chapter will examine two pre-'Prelude' attempts at the episodic story to identify typical "relationship" techniques used in them and suggest resulting interpretations. The intention is to use the more obvious textual relationships identified in this chapter as a basis for examining the more subtle interconnections in 'Prelude’.

'Juliet' (written June 1906 to January 1907) and 'Brave Love' (completed February 1915) have been chosen for this investigation because they were written at the beginning and end of the time span preceding Mansfield's first published episodic story, 'Prelude', which marked her entrance into maturity as a writer. 'Juliet', started while Mansfield was still at school and consisting of fragments, can be considered as the rudiments of an episodic story; and 'Brave Love' is her last attempt at this longer form of fiction before, shortly after completing it, she began work on 'The Aloe'. Both stories were unpublished in Mansfield's lifetime and have attracted relatively little critical attention. In spite of the span of over seven years between them, they demonstrate a number of similar "relationship” techniques. However, to briefly look at others' views of Mansfield's early work and suggest the approach of this chapter, it is first useful to explore an early Mansfield text that, unlike 'Juliet' and 'Brave Love', has been much commented on: the vignette 'In the Botanical Gardens', first published in the Australian Native Companion in December 1907.

Studies of Mansfield's early work have tended to concentrate on pieces that she successfully submitted for publication. Prose poems ${ }^{45}$ were one of Mansfield's favourite forms in her early writing: several of these were published in 1907-8. Commentators on Mansfield's use of this genre have approached them from a variety of angles. Hanson and Gurr, for example, in accord with their symbolist approach to her work, state that Mansfield's prose poems published during these years were "all in the symbolist mode - the prose poems titled 'Vignettes', 'Silhouettes', ... 'In the Botanical

45 Clare Hanson and Andrew Gurr, Katherine Mansfield (London: Macmillan, 1981), p. 28. 
Gardens', [and] 'Death of a Rose’”. ${ }^{46}$ They point out that "[t]he structure of the vignettes resembles that of a Symbolist poem”, with only a nominal narrative framework and with the main focus on a series of images, which cohere and combine to create a mood. ${ }^{47}$

Later commentators have begun to recognise aspects of relativism in Mansfield's work, including the prose poems. For example, Angela Smith mentions "the relativism that Mansfield was already [by 1910] exploring in her writing, for instance in her comparison of Maori and Pakeha cultures”. ${ }^{48}$ As noted in the introduction, Pater's view of relativism involved the idea of interrelated opposites, merging and changing into one another. Thus a relativistic text intending to merge oppositions might include not only a sense of the binary but also ways of interrelating them, such as related or recurring phrases, concepts, and motifs. Though some Mansfield commentators have noted both the binary and the recurrent in Mansfield's early work, they have seldom explored them in combination. Saralyn Daly mentions the use of "repeated image[s], the usual unifying trick" 49 in Mansfield's early work - a practice that Daly considers Mansfield soon abandoned with increasing maturity as a writer. Angela Smith suggests that the ending of 'In the Botanical Gardens' "juxtaposes the two elements of [the narrator's] cultural being”, which she sees as an example of Mansfield's “developing awareness of divisions in the self” 50 and as an example of her exploration of relativism. ${ }^{51}$ In her discussion of the slightly later (probably 1908) unpublished story 'His Sister’s Keeper’, Smith also shows how Mansfield’s writing can set up and undermine apparent oppositions by bringing out similarities between them. ${ }^{52}$ W.H. New's recent study of Mansfield's use of conventional language forms in her fiction recognises, at different times, the binary and the recurrence of phrasing in these early sketches (as he terms them). In 'In the Botanical Gardens', New reads “a distinction between centre and margin" that is "binary", allowing "no other options" and involving two kinds of conventional narrative; ${ }^{53}$ but New does not explore recurring patterns in this piece. In 'Vignettes', New identifies recurrent phrasing that

\footnotetext{
${ }^{46}$ Hanson and Gurr, p. 28.

${ }^{47}$ Hanson and Gurr, p. 27.

${ }^{48}$ Smith, A Literary Life, p. 59.

49 Saralyn Daly, Katherine Mansfield (New York: Twayne Publishers, 1965), p. 49.

${ }^{50}$ Smith, A Literary Life, p. 27.

${ }^{51}$ Smith, A Literary Life, p. 59.

${ }^{52}$ Smith, A Literary Life, p. 57.

${ }^{53}$ W. H. New, Reading Mansfield and Metaphors of Form (Montreal: McGill-Queen’s University Press, 1999), p. 47.
} 
links the three-part structure and that he reads as suggesting the illusory nature of change. ${ }^{54}$

\section{'In the Botanical Gardens'}

Because of the interest taken in it by recent critics, 'In the Botanical Gardens' is a useful basis for summing up their viewpoints and going on to preview the approaches to be followed in this chapter. As New and Smith each point out, this two-page sketch contrasts the way in which the narrator experiences the sunny, brightly flowering, crowded public walks of the gardens and their shadowy, silent bush area. Smith reads the piece as "a sympathetic engagement with Maori dispossession" that ends by "juxtapos[ing] the two elements of [the narrator's] cultural being”. ${ }^{55} \mathrm{New}^{56}$ sees the two aspects of the gardens as representing unworkable options (both of which are conventional) for the narrator. A third commentator, Sydney Janet Kaplan, suggests that the explicit contrast of the "civilised" with the "ancient powers of the wilderness" (Kaplan's terms) gains meaning from the "strength of female imagery” in the bushrelated passage, which however is "already mannered, stylistically akin to the arranged gardens, containing within it the impurities of nostalgia”. ${ }^{57}$ As all three commentators have sensed in recognising the artificial or stereotypical language in both parts of the text, the two contrasted sides of the gardens are linked, but this linkage can be read as deliberate. The interconnections of the two sides, by means of allusions and repeated concepts, offer wider possibilities for reading the piece, which provide a satisfying sense of the multidimensional and explorational.

A fourth study, the most recent of those mentioned here, has dispensed with the idea of the binary, reading the piece as "conveying a particular kind of sensibility: that of a young woman ... driven by impulses she does not fully understand and cannot control", with the implication that "sexual energy is the source of uncontrol". ${ }^{58}$ This sense of being uncontrollably driven is indeed conveyed by the piece, but its “relationships” suggest more complex forces than the sexual alone. Williams' comment that a loss of control is a typical experience expressed in the vignettes is supported by similar experiences in 'Juliet' (to be discussed below).

${ }^{54}$ New, p. 48.

${ }^{55}$ Smith, A Literary Life, pp. 25-27.

${ }^{56}$ New, p. 46.

${ }^{57}$ Sydney Janet Kaplan, Katherine Mansfield and the Origins of Modernist Fiction (Ithaca and London: Cornell University Press, 1991), pp. 56-57.

${ }^{58}$ Jane Stafford and Mark Williams, Maoriland: New Zealand Literature 1872-1914 (Wellington:

Victoria University Press, 2006), p. 150. 
'In the Botanical Gardens, ${ }^{59}$ can be read as ironically contrasting the narrator's sense of control, certainty, and individuality with a background of vast impersonal forces. The narrator's phrasing in terms of subjective responses and questioning suggests her unreliability. The contrast between the narrator's repudiation of the "artificial" side of the gardens and choice of the "natural" side is subverted by images that underlie them both.

A drama of the narrator's personal choices is conveyed by perceptions expressed as invitations. So the scent of cowslips is "like hay and new milk and the kisses of children"; a magnolia flower is a "pearl rose loving-cup"; anemones seem "a trifle dangerous, sinister, seductive, but poisonous”. The impression that the narrator refuses these options (mostly offered in terms of food or drink) is conveyed by her continuing past them and by her disparaging value judgments preceding them, such as "the orthodox banality of carpet bedding" and people who "seem as meaningless, as lacking in individuality, as the little figures in an impressionist landscape”. Once the narrator has made the conscious choice to "turn from the smooth swept paths", the value judgments and subjective statements become rapturous and identifying: "there is bush, silent and splendid"; "I am old with the age of centuries, strong with the strength of savagery”; “this is the Lotus Land”; “An inexplicable, persistent feeling seizes me that I must become one with it all”. A further conscious choice to drink water from the stream is followed by a series of questions that are not answered: "Oh! is it magic? Shall I [...] see vague forms lurking in the shadow [...]? Shall I [...] see a great company $[\ldots]$ moving towards me $[\ldots]$ ?" These questions become the focus of the reader's own questioning about the nature of the narrator's experience and what "the bush [that] lies hidden in the shadow” (the vignette’s final words) means for the narrator's future. The ironic background offers possible answers to the mystery of the narrator's experience.

The ironic background is conveyed by another set of concepts that links the two groups and the narrator. The noisy present-time visitors to the gardens and the visionary past inhabitants of the bush are both contrasted and shown as similar. The visitors to the gardens "stroll” "[f]rom the entrance gate down the broad central walk"; the noisy presence of “a great many children” among them suggests this group’s burgeoning population. The Maori people that the narrator attempts to visualise in the

${ }^{59}$ Julian Mark (pseud.), 'In the Botanical Gardens', Native Companion (2 December 1907), rpt. Katherine Mansfield: New Zealand Stories, selected by Vincent O’Sullivan (Oxford University Press New Zealand), pp. 18-20. All quotations from 'In the Botanical Gardens' are from this publication. 
bush, on the other hand, are in mourning (wearing garlands of green leaves was a sign of mourning at the 2006 funeral of the Maori Queen), silent, and travelling seawards: "moving towards me, their faces averted, wreathed with green garlands, passing, passing, following the little stream in silence until it is sucked into the wide sea ...”. Smith argues:

[t]he phrase "passing, passing" from the shore to the wide sea suggests annihilation, hinting at social Darwinism, the contemporary white belief that 'inferior' races would eventually become extinct". ${ }^{60}$

Simultaneously, however, the difference between the two groups is counteracted by the fact that both are part of a wider and inevitable downward movement of peoples, which includes the narrator. The first group moves "down the broad central walk"; the second follows the stream's downward movement to the sea. The narrator's initial climb "up a steep track" on entering the bush also gives way to an emphasis on downward movement: "I follow the path down and down”, "I fling myself down, and put my hands in the water”, "Bending down, I drink a little of the water”, "Shall I, down the hillside, through the bush, ever in the shadow, see a great company moving towards me”. In the last example, the placement of "down” is ambiguous, referring either to "I" or the "great company". The narrator's return to the gardens' entrance ("I pass down the central walk towards the entrance gates") connects her more obviously with both groups - in her physical presence among the crowd of visitors and in the verb "pass down”, which echoes the second group's "passing, passing” and their downward movement towards the sea in the bush passage. The narrator's downward movement can be read as part of a wider drift of peoples from growth to diminishment - a concept reinforced by the reference to fragments of lost cultures (in "the Latin names of the flowers" and "the Lotus Land”). She is also part of a personal movement between birth and death, origin and displacement, suggested by her identification with the imagined passing inhabitants of the bush: Smith suggests that if the narrator “'becomes one' with the great company with averted faces, she is aligning herself with death". 61 The imagined weeping of the trees that follows the narrator's vision continues the sense of mourning, for individuals as well as peoples. The author's pseudonym, Julian Mark, suggests similar contrasts of individual fate (in the word “Mark” read as "stigma”) as well as the historical and cultural changes affecting

\footnotetext{
${ }^{60}$ Smith, A Literary Life, p. 27.

${ }^{61}$ Smith, A Literary Life, p. 27.
} 
peoples (in the connotations of the apostle Mark and the Roman emperor Julian the Apostate).

Another cultural reference also supports the above implications. The narrator's perception in the bush that "Remembrance has gone - this is the Lotus Land" recalls Tennyson’s poem ‘The Lotos-Eaters'. That poem’s image of eating the lotus results in forgetfulness of origin: ${ }^{62}$ as the poem states,

Then some one said, "We will return no more;"

And all at once they sang, "Our island home

Is far beyond the wave; we will no longer roam." 63

The allusion to the edible lotus continues the images of invitation expressed through flowers in the first half of 'In the Botanical Gardens'; and the fact that the stream is “idly, dreamily floating past” reinforces the lotus association with the idle, dreaming mariners of the poem:

Somewhere I hear the soft rhythmic flowing of water, and I follow the path down and down until I come to a little stream idly, dreamily floating past. I fling myself down, and put my hands in the water. An inexplicable feeling seizes me that I must become one with it all. Remembrance has gone - this is the Lotus Land - the green trees stir languorously, sleepily - there is the silver sound of a bird's call. Bending down, I drink a little of the water, Oh! is it magic? Shall I, looking intently, see vague forms lurking in the shadow staring at me malevolently, wildly, the thief of their birthright? Shall I, down the hillside, ever in the shadow, see a great company moving towards me, their faces averted, wreathed with green garlands, passing, passing, following the little stream in silence until it is sucked into the wide sea ...

There is a sudden, restless movement, a pressure of the trees - they sway against one another - it is like the sound of weeping ...

The narrator's immediately following choice, after thinking of the bush as "the Lotus Land”, to drink from the stream continues the lotus association with forgetfulness and with the drift away from origin. The narrator's bypassing the earlier symbolic options offered by the cultivated gardens has been followed by a choice that seems to identify with departure: by this reading, the narrator does "become one with it all” in the ironic sense of symbolically participating in a movement that carries her away from her environment. But the phrase "become one with it all" is ambiguous: "it" could mean both contrasting sides of the gardens, so that Smith can state: “The impetus of the

\footnotetext{
62 Smith sees 'The Lotos-Eaters' as “itself a poem about the colonial process, and the sailors' temptation to forget links with the 'Fatherland'” (A Literary Life, p. 27).

63 Alfred Tennyson, 'The Lotos-Eaters', Poems of Tennyson (London: Thomas Nelson and Sons, n.d.), p. 83.
} 
passage is the speaker's need to identify with this bifurcating experience”. ${ }^{64}$ The piece ends with exactly that juxtaposition of the bright and shadowy sides of the garden, a technique that is also characteristic of Mansfield's episodic stories, which tend to conclude by juxtaposing two characters and/or viewpoints: "Here is laughter and movement and bright sunlight - but behind me - is it near, or miles and miles away? the bush lies hidden in the shadow." The restatement of the contrasting sides, combined with questioning, invites the reader to recall the text's multi-levelled implications of movement, decision, and departure. In Mansfield's work, images of being driven are to recur as late as in 'At the Bay’ (1921), for example, in the shepherd and sheep images of its first section.

An investigation of the way, then, in which different elements relate to each other in a Mansfield text can greatly deepen the ways in which the reader perceives and questions it. This vignette's movement up to and away from the narrator's drink of water from the stream throws the text's emphasis on that moment and on the questions that follow it. The moment also points backwards and forwards in time. However, the ambiguity of the crucial moment, and different readers' perception of what evidence is available to construct a meaning, allows always for different possibilities. The text is modernist by its "deliberate dislocation of parts, in which very diverse components are related by connections that are left to the reader to discover, or invent". ${ }^{65}$ This text's deliberately contrasted oppositions are also connected, and wider forces qualify the narrator's supposed control and choice of her destiny.

\section{'Juliet'}

Mansfield's shorter texts tend to explore a brief time span (of a day or part of a day), very few characters, and a single setting. Her longer, “episodic” stories, on the other hand, allow for longer time spans with a greater contrast of settings and characters and a deeper, more complex exploration of theme. The "episodic story" is my term for Mansfield's longer kind of short story, or novella, that includes 'Prelude' and 'At the Bay'. The basic criterion for grouping these stories together is their length (around thirty to fifty pages) and their division into separate, numbered sections. Including 'Juliet' in this group could appear arbitrary because it was originally intended to be a novel; but Mansfield also used the term "novel” when referring to what turned out to be

\footnotetext{
64 Smith, A Literary Life, p. 26.

${ }^{65}$ Abrams, p. 167.
} 
another episodic story, The Aloe ("I fell into the open arms of my first novel" 66 - letter to Murry, 25 March 1915). Although incomplete, 'Juliet' is about the same length as 'Brave Love' (about twenty pages of the The Katherine Mansfield Notebooks), although some passages could be alternative versions signalling different treatment or plot directions. The passages, which are not written in plot sequence, vary widely in length, from several pages to a few lines; many are obviously only fragments of projected larger sections. The "relationship" techniques used in this text show similarities to those in her later episodic stories. A comparison of 'Juliet' and 'Brave Love' shows some "relationship" techniques in common.

Most commentators, when mentioning 'Juliet' at all, have emphasised its immaturity and lack of interest for critical purposes. Of the few who have discussed this text in any depth, none have paid its "relationships" more than passing attention. In her introduction to the Katherine Mansfield Notebooks, Margaret Scott describes 'Juliet' as Mansfield’s

first piece of sustained (albeit autobiographical) fiction ... KM was still at school in London, aged 17, when she began 'Juliet', and eight or nine months later she abandoned it. It could fairly be described as "Notes towards a novel" as it consists of a series of disconnected episodes ... and these are not written in the order that the chronology of the final narrative would demand. Nevertheless it is possible to piece together the main outline of a story, and to perceive the weaving in of themes which were to remain central to her for the rest of her life. $^{67}$

Elsewhere, Scott notes these themes as

early death, unrequited love, art $v$ commerce, London $v$ New Zealand, experience $v$ conventional behaviour. And all through Juliet and many other of the unpublished pieces of this period, is the recurring crisis of falling. ${ }^{68}$

Two other commentators who have shown more than passing interest in 'Juliet' are Cherry Hankin and Sydney Janet Kaplan. Hankin enlarges on the motif of falling in 'Juliet' by connecting it with the finality of death; ${ }^{69}$ she also, in her psychology-related approach to the text, identifies that Juliet is torn between the oppositions of conventionality and unconventionality. ${ }^{70}$ However, Hankin states that "[Mansfield]

${ }^{66}$ KM Letters (O and S), vol. 1, p. 167.

${ }^{67}$ KM Notebooks, vol. 1, p. 48.

${ }_{68}$ Margaret Scott, “The Unpublished Manuscripts of Katherine Mansfield”, The Turnbull Library Record (March 1970), p. 5.

${ }^{69}$ Cherry Hankin, 'Fantasy and the Sense of an Ending in the Work of Katherine Mansfield', Modern Fiction Studies, vol. 24 no. 3 (autumn 1978), p. 470.

${ }^{70}$ Cherry A. Hankin, Katherine Mansfield and Her Confessional Stories (London: Macmillan, 1983), p. ? 
was not able to impart any coherence to the disconnected episodes". ${ }^{71}$ In fact, the fragments can be shown to cohere (some more than others) by "relationship" techniques.

Kaplan's extended discussion of 'Juliet' approaches it in terms of a female artist's life in the city ${ }^{72}$ and the text's demonstration of progress towards modernist techniques, such as stream-of-consciousness fiction and the artificial arrangement of details, including foreshadowing, to "convey the nature/culture conflict". ${ }^{73}$ Like Hankin, Kaplan senses conceptual oppositions built into the text. She also contrasts two scenes in which Juliet is lastingly affected by music played to her by two different male artists, David and Rudolf; ${ }^{74}$ these two scenes are in fact parallels, with the second intended to echo the first as part of the ironic structure.

Although, in terms of "relationships”, 'Juliet' offers a rewarding reading, the fragments contain a variety of these techniques, from simple to complex and scattered randomly throughout. Picking up these "relationships" depends on identifying an intended sequence to the fragments, as suggested below, although that sequence does contain disparities between versions of the plot. The most reliable transcription of 'Juliet' is that by Margaret Scott. ${ }^{75}$ The letters of the alphabet listed with the sections are reference marks used by Scott. Asterisks mark the sections that most clearly display “relationships” as discussed in this chapter.

Suggested sequence:

A*: introduction and Juliet's first two meetings with David (pp. 48-53)

H, I, R: fragments of her childhood (pp. 56-57, 66)

T: Her dream of climbing and falling (pp. 68-69)

B: Juliet's and David's parting in New Zealand (p. 53)

C: Her arrival at school in London (p. 53)

Q: Her first impressions of school life and meeting with Pearl (pp. 65-66)

S: Juliet's decision to stay in London with Pearl (pp. 66-68)

H: Juliet's visit to “The Man” to thank him for advising her to put an end to “complications" - probably her relationship to David since in the following section, Juliet considers herself emotionally free of David (pp. 55-56)

\footnotetext{
${ }^{71}$ Hankin, Confessional Stories, p. 25.

${ }^{72}$ Kaplan, Origins of Modernist Fiction, p. 73.

${ }^{73}$ Kaplan, pp. 91-92.

${ }^{74}$ Kaplan, p. 95.

${ }^{75}$ KM Notebooks, ed. Margaret Scott, vol. 1, pp. 48-69. All quotations from 'Juliet' are from this version.
} 
$\mathrm{J}^{*}$ : Juliet and Pearl living together in London in winter, ending with the hansom accident (pp. 57-59)

$\mathrm{E}$ and $\mathrm{F}^{*}$ : Juliet's finding of a flat, her sense of isolation in London, and her discovery by David (pp. 54-55). These sections could be alternatives of plot to section J.

L*: Juliet's seduction by Rudolf (pp. 59-62)

$\mathrm{D}^{*}$ : Her return, after the episode with Rudolf, to the flat that she shares with Pearl (p. 53). The placing of this key fragment is made likely by the fact that in the course of it, Juliet falls twice in her sitting room, the second time presumably onto her sofa, where David (in M) says he has seen her asleep when he took Pearl home.

$\mathrm{M}^{*}$ : Rudolf and David discussing Pearl and Juliet later on the same evening as the seduction (pp. 62-63)

No letter*: dinner party of Rudolf, “Caesar” (David), and two friends (p. 53)

$\mathrm{N}^{*}$ : Juliet's first suspicion that she is pregnant (pp. 63-64)

O*: Her approaching illness (pp. 64-65)

$\mathrm{P}^{*}$ : death of Juliet (p. 65)

$\mathrm{K}^{*}$ : epilogue (p. 59).

'Juliet' is the story of an aspiring writer who breaks away from her conventional family to live and work in London, is betrayed by her friends, is seduced, and dies as a result of the ensuing pregnancy. The story is built on the contrast between Juliet's expectations and her actual experience. Similarly to 'In the Botanical Gardens', the ironic background to 'Juliet' qualifies the characters' perceptions, and the text's ironic structure involves the synthesis of apparent opposites.

Commentators on 'Juliet' have recognised the story's basic opposition of the conventional and unconventional. As well as identifying a theme of being torn between the two, Hankin has noted that during the course of the story, the apparently exciting, unconventional friends, David and Pearl, take on the characteristics of conventional parental figures replacing Juliet's own parents. ${ }^{76}$ Kaplan, in her feminist approach to the text, also recognises the irony that David and Pearl have become conventional by the story's end, in line with Rudolf's conventional response to Juliet's death in positioning her as "woman as muse, woman as inspiration". ${ }^{77}$ In fact, an ironic plot unfolds: not only the people in Juliet’s new life but also its events and

\footnotetext{
${ }^{76}$ Hankin, Confessional Stories, p. ?.

${ }^{77}$ Kaplan, p. 94.
} 
characteristics resemble what she feared in her previous lifestyle, with the final result that she is literally killed by its crushing and stifling effects. The plot is built on this contradiction. The following sections of this chapter will explore techniques that imply a background in common to the conventional/unconventional polarities: these techniques are setting-derived images, parallel scenes, myths, and the irony of unreliable perceptions.

\section{The irony of unreliable perceptions}

Like that of 'In the Botanical Gardens', the foreground of 'Juliet' conveys the drama of a character's personal choice and sense of individuality and self-control. In both texts, the character chooses between two clearly presented options by disparaging one and rapturously welcoming the other, but ironic techniques are used to suggest the unreliability of the character's perceptions. In 'Juliet', the characters' comments, perceptions, and responses reflect the author's ironic undermining of their sense of personal destiny.

In section S, deciding whether to live in London with Pearl, Juliet contrasts the apparent freedom of bohemian life with the stifling, constraining, market-driven qualities of the conventional world:

On one hand lay the mode boheme - alluring, knowledge-bringing, full of work and sensation, full of impulse [...] On the other hand lay the Suitable Appropriate Existence. The days full of perpetual Society functions, the hours full of clothes discussions - the waste of life. The days - weeks - months years of it all. The stifling atmosphere would kill me, she thought. Her father, with his successful characteristic respectable face, crying "Now is the time. What have I got for my money. Come along - deck yourself out, show the world that you are expensive [...] You must learn to realise that the silken cords of parental authority are very tight ropes indeed. I want no erratic spasmodic daughter. I demand a sane healthy-minded girl - It is quite time for you to put up the shutters upon this period.” In the darkness Juliet smiled at the last expression. It was so exactly like him - an undeniable trade atmosphere. ${ }^{78}$

However, Juliet's perceptions in the above passage are ironically qualified by echoing phrases and similar concepts that connect the two worlds of the conventional and the unconventional, suggesting that they are not as dissimilar as Juliet supposes. For example, Juliet's mother's “ 'Do be careful of your clothes, child [...] and don't be late”,79 is recalled later in Pearl's “ 'Well run along or you'll be late dear'”, ${ }^{80}$ Phrases

${ }^{78}$ KM Notebooks, p. 67. The punctuation accurately reflects Mansfield's own as transcribed in the Notebooks. The bracketed ellipses are mine.

${ }^{79}$ Ibid., p. 50. 
from section S (quoted above), in which Juliet contrasts the conventional and bohemian lifestyles, are later echoed (with ironic effect) in mundane or disillusioning circumstances. "Taking the plunge", ${ }^{81}$ about making the change to the new life, recurs when Juliet is living with Pearl in " 'I shall take the plunge dear, and bring you back a brown loaf for supper", ${ }^{82}$ (section J). Also in section J, the "stifling atmosphere” that Juliet fears in her conventional life is recalled as "the rain [...] seemed to be suffocating her". ${ }^{83}$ Following Juliet's initial excitement at her "gloriously unconventional" " visit to "The Man" in section G is her perception of his "fearful paternal conceit”. ${ }^{85}$ To seduce Juliet (section L), Rudolf ridicules her lack of the very qualities she thought she had chosen, calling her “ 'conventional”, “ 'afraid””, and with “ 'no core of sensation'”. 86 “' 'I am suffocated”, ${ }^{87}$ Juliet exclaims in protest against Rudolf's domination. David later tells her, “ '[...] you are wasting your life”,,88 (echoing “ 'the waste of life”" from section S) as he tries to persuade her to return to the conventional world. The finality of "Death put his hand over her mouth" ${ }^{89}$ again recalls Juliet's fear of suffocation. Again in section S, Juliet's moment of decision for life in London was signalled by “ 'Yes, yes - I have the Key in my hands. Shall I unlock the door and get through \& then shut it again, bang it again with all the old Life outside - and Pearl and I alone at last." ${ }^{90}$ This moment is ironically recalled when Juliet enters her empty flat in a state of shock after the Rudolf episode: “Juliet stumbled up the stairs - somehow she reached the door and let herself in and locked it again”. 91 These echoing phrases both emphasise and undermine the plot's juxtaposition of the conventional and unconventional, since they interconnect the two worlds with experiences that are similar (such as feeling stifled) and can contrast with its enthusiastic anticipations (such as "taking the plunge”). They also imply unreliability in the characters' viewpoints.

The characters' use of the word "change” supports the background of irresistible forces implied by the irony of suffocating qualities in both worlds. In several of the

${ }^{80}$ Ibid., p. 59.

${ }^{81}$ Ibid., p. 67.

${ }^{82}$ Ibid., p. 58.

${ }^{83}$ Ibid., p. 57.

${ }^{84}$ Ibid., p. 55.

${ }^{85}$ Ibid., p. 56.

${ }^{86}$ Ibid., p. 61.

${ }^{87}$ Ibid., p. 62.

${ }^{88}$ Ibid., p. 64.

${ }^{89}$ Ibid., p. 65.

${ }^{90}$ Ibid., p. 67.

${ }^{91}$ Ibid., p. 53. 
fragments, this word is used in assertions that change has or has not occurred in desired or undesired ways. All convey the irony of expected versus actual change (or its lack). Juliet's joyous affirmation that "the whole world had changed"92 after her meeting with David (section A) is contradicted by her recognition in F that "it was hopeless to attempt to change” her character - to become “ 'masculine”, “ “ 'independent””, and “ 'complete”,. 93 Conversely, Walter's comment “ "You have changed'” in a “curiously altered” voice conveys his surprise and admiration at Juliet's unexpected selfpossession as "she sat very still \& suddenly smiled slightly"94 (section G). The word is most repeated in $\mathrm{O}$ as David contrasts his and Juliet's youthful aspirations with what he and she have since become:

"You are so changed - it is not right - you are wasting your life [...] How we change, Juliet. When we first knew each other, both so young, so full of quaint romantic impossibilities - but those two children are dead now \& we are man and woman - all is different. You made a mistake - for the sake of your old view, Juliet, try \& go back." 95

Other passages express characters' recognition that they should be behaving differently but that they cannot help themselves. So Juliet in section F (p. 54-5):

"How weak I am. How I ought to be full of strength, \& rejoicing all the day" [...] She shook from head to foot with pain and anger with herself [...] Try as she would she knew that it was hopeless to attempt to change. ${ }^{96}$

Similar is David (section M): “ 'I feel as though I ought to love [Juliet] ... but I do not.” 'Instead, “ 'I cannot help myself. I am madly in love with Pearl [...] The Lord only knows how this will end." 97 This inability of the characters to prevent themselves from being swept away by events and emotions is particularly emphasised by the ironic contrast between Juliet's care in making the right decision and what those decisions lead to. Juliet's final decision to live with Pearl (who ends by betraying her) is made after much hesitation because this matter " 'is rather immense \& requires consideration'”98 (section S). In section L, Juliet dresses with great care to meet, as she thinks, David, whereas she will confront Rudolf instead, who mocks the details of her outfit. ${ }^{99}$ This contrast between decision making and inevitable capitulation to

${ }^{92}$ Ibid., p. 51.

${ }^{93}$ Ibid., p. 55.

${ }^{94}$ Ibid., p. 56.

${ }^{95}$ Ibid., p. 64.

${ }^{96}$ Ibid., pp. 54-55.

${ }^{97}$ Ibid., p. 63.

${ }^{98}$ Ibid., p. 67.

${ }^{99}$ Ibid., pp. 59 and 61. 
events is similar to the contrast, in 'In the Botanical Gardens', between the drama of the narrator's personal choice and her joining the inevitable downward drift of peoples.

The characters' interpretations and questions about the story's events serve to arouse the reader's own questioning and encourage him or her to dig deeper in the text for answers.

\section{Setting-derived images}

Other elements that connect the conventional and unconventional worlds are settingderived images of rose, wheel, wind, and water together with oppositional motifs of climbing and descending or falling; moving to and fro ("up and down”"100), lightness and heaviness, strength and weakness, and light and darkness. Some motifs and images are associated with Juliet only, bridging both worlds; and others with the remaining characters in either world or as they move between them. Some associated with Juliet only are her sense of lightness, strength, and motion at the beginning of the story, and heaviness, weakness, and immobility at the end of it. Only some of these motifs and images can be examined here.

Most obviously, the rose image, associated only with Juliet, recurs in changing forms at pivotal stages of her story. In section A, “a vase of red roses stood on the dressing table”, ${ }^{101}$ and David gives Juliet a rose at their first meeting. ${ }^{102}$ “O, the late roses below them - thousands there seemed to Juliet”"103 suggests the magnificent potential of life to her at that moment. On her way to discuss her play with David, half expecting to be “ 'crushed to death"” ${ }^{104}$ by his criticism, Juliet tucks two pink roses into her belt, which are crushed when Rudolf seduces her. ${ }^{105}$ David later unknowingly emphasises the link between the damaged roses and the seduction by mentioning that he has seen Juliet sleeping on the sofa in her flat, wearing " 'the remains of these blossoms "”. ${ }^{106}$ In section D, on Juliet's return to her flat after the episode with Rudolf, " $[\mathrm{t}]$ he wind had blown over the roses on the table, and they lay in a crushed heap on the carpet”. ${ }^{107}$ So the destruction of roses is doubly emphasised in sections L, D, and M. The life and death of roses becomes a symbol for Juliet's life, hope, or potential: taken

\footnotetext{
${ }^{100}$ For example, ibid., p. 57.

101 Ibid., p. 49.

102 Ibid., p. 51.

103 Ibid., p. 51.

${ }^{104}$ Ibid., p. 59.

105 Ibid., p. 63.

${ }^{106}$ Ibid., p. 63.

107 Ibid., p. 53.
} 
together, the rose images add up to one of process. This symbol supports an explicitly expressed theme of change.

The fallen roses in section $\mathrm{D}$ are associated with being crushed and with the irresistible force of the wind (as in "the fierce wind that beat upon her face she could hardly stand against” ${ }^{108}$ in Juliet’s dream of climbing and falling, section T). As noted above, commentators have remarked on the recurrence of the motif of falling in 'Juliet', but this is only one of the interrelated images superimposed on the two opposed worlds. The image of the turning wheel, possibly derived from the wheel of fortune or the Buddhist image of the wheel of life, is of importance in Mansfield's work. In section D of 'Juliet', this image suggests that Juliet's falling (like the fallen roses that "lay in a crushed heap on the carpet”) is caused by an inexorable force of blind circumstance:

She shivered incessantly from head to foot, and a wheel began to go round \& round \& round in her head. "Down \& down \& down \& down \& down" said the wheel as it whirred [...] Then it assumed gigantic proportions, and she clung to it and it dragged her round. Round \& round \& round \& round \& round in a great pit of darkness - and she fell. ${ }^{109}$

However, the wheel image, particularly as visible only in Juliet's mind, can also be read as a hallucination expressing the extremity of her state of mind at that moment - her sense (perhaps a conventional one) of degradation and loss of control. This image is also derived from the setting: it is implied in the hansom accident in which a man is killed in the London streets ${ }^{110}$ (section J). This event, concluding the section depicting Juliet's sexual frustration and loss of control, could have been intended to directly precede section L, in which she is seduced. This is an early example of the Mansfield technique (often used in 'Prelude') of concluding a section with an image that points towards the next section.

The possibility that the wheel image in D expresses a wider reality than just Juliet's state of mind is suggested by echoes of its turning "round" and "down" in other sections and in relation to both Juliet and other characters. The wheel image has both psychological and philosophical meaning. In the conventional world, Juliet's father is shown "pacing up \& down, up and down"111 in his annoyance with Juliet (section I). Juliet (suffering from “a mood”) in the unconventional world walks “round \& round

\footnotetext{
${ }^{108}$ Ibid., p. 69.

${ }^{109}$ Ibid., p. 53.

${ }^{110}$ Ibid., pp. 58-59.

${ }^{111}$ Ibid., p. 57.
} 
this room” until Pearl's pen "describ[es] a hopeless and idiotic circle”112 (section J). In the aftermath of the seduction (section N), Juliet listens to Pearl's footsteps “going down down down, then along the corridor \& then lost”"113 as Pearl moves out of Juliet's orbit, drawn to a different life from the one she and Juliet had planned. All these situations are those of loss of control. (A less obviously emphasised repetition of “down” was also pointed out in 'In the Botanical Gardens', there associating the stream image with individuals’ and peoples’ movement away from origin.) The wheel image in 'Juliet' and its associations with a range of characters is an early example of Mansfield's use of this technique, later employed in a more developed way in 'Prelude'; the wheel image itself recurs with similar meaning in 'Brave Love'.

\section{Parallel scenes}

This technique aligns the imagery of two scenes so that the second has overtones of ironic commentary on the first. The passages in which Juliet first meets David and then hears him play (section A) are juxtaposed with section L, in which she encounters Rudolf. Similar elements of the first meeting in $\mathrm{A}^{114}$ and the one in $\mathrm{L}^{115}$ are: Juliet's care in dressing; her entering a room and meeting someone unexpected; her standing by a table in the centre of the room; and the motif of wearing a rose in her dress. The imagery of roses, music, stars, sea, nights, and first love in the idealistic two meetings of section A recurs in altered form in the disillusioning encounter with Rudolf. In section $\mathrm{L}$, the roses are crushed, the music is used to dominate and drown the protesting voice, and the earlier experience of rapturous first love is contrasted with sexual exploitation. A further irony that underlies section L is that David's unexpected absence (which allows the seduction to take place) is the result of his and Pearl's mutual attraction, so that all three of Juliet's friends betray her simultaneously. Kaplan responds to juxtaposed elements in these two scenes as follows:

Juliet's seduction by Rudolf is played out in a scene where the power of music is destructive, not like its effect earlier in the novel when David's playing evokes in Juliet intense aspiration, a striving after her own creativity, which, like the sexuality implicit behind it, would flower in fullness and purpose. With Rudolf, it is a sexuality controlled, manipulated by the male intrusion of power. ${ }^{116}$

\footnotetext{
112 Ibid., p. 57.

113 Ibid., p. 64.

${ }^{114}$ Ibid., pp. 48-53.

115 Ibid., pp. 59-62.

${ }^{116}$ Kaplan, p. 95.
} 
Although Rudolf's manipulation of Juliet is undeniable, the events of the seduction scene are qualified by an implied concert scene, simultaneous to the seduction but only mentioned afterwards by David. The element common to the concert and the seduction scenes is the music of Wagner, which is hinted at as simultaneously deepening all four characters' sexual and emotional responses to one another, so that all are carried away in unexpected directions. When David returns to his and Rudolf's apartment after the seduction, David comments that:

"I'm still full of Wagner, \& behold I find he is here incarnate in my room." "Yes, yes" said Rudolf [...] "I am Wagner - I'm at the top of the whole world, and it is rather strange."117

David then explains that he has just returned from attending a promenade concert with Pearl and admits: "I cannot help myself. I am madly in love with Pearl."118 It is implied that the music of Wagner has swept away both couples at the same time. In a journal beginning at the date October 1908, Mansfield has noted what could be quotations from Arthur Symons: "In the music of Wagner there is that breadth \& universality by which emotion ceases to be personal and becomes elemental”. ${ }^{119}$ On the same page, she jots down elements associated with different Wagner operas (“Parsifal - light; Tristan - sea; Ring - fire”). So in 'Juliet' (which however predates the Wagner jottings by nearly two years), the music of Wagner could be read as symbolising elemental, universal forces that are irresistible. The function of the plot of Tannhäuser, referred to by Rudolf during the seduction, will be referred to later.

Another pair of ironically linked scenes in 'Juliet' consists of section S, in which Juliet makes her decision to live with Pearl in London, ${ }^{120}$ and section P, the scene of Juliet's death. ${ }^{121}$ They are linked by the situations of Juliet's lying in darkness through the day with the blinds or shutters drawn and by the presence of Pearl, so that the earlier situation foreshadows the later one. Both signal momentous change. In section S, Juliet's decision (achieved only after much soul-searching during the night) to live in London brings on a nervous headache next morning, so that she has to stay in bed; but the whole section, culminating in Pearl's visit, is pervaded by the excitement of the new life that lies ahead. Section P, in which Juliet lies "straight \& still” in her darkened room and is observed by Pearl and David, expresses Juliet's sense of

${ }^{117}$ KM Notebooks, p. 62.

118 Ibid., p. 63.

${ }^{119}$ Ibid., p. 214.

${ }^{120}$ Ibid., pp. 66-68.

${ }^{121}$ Ibid., p. 65. 
hopelessness and betrayal and has the imminence of death. Though some motifs in common are obvious, such as Juliet’s lying "still” in both cases and her suddenly sitting up or raising herself at the end, the "relationships" between these two scenes are not as densely worked out as in sections A and L, discussed above, since Juliet's deathbed scene is only a sketch. Juliet's headache connects with a further theme of characters’ physical reactions after periods of excitement - for example, Juliet's feeling “tired \& depressed”"122 after climbing the hill (section A) and David’s “infernal headache” after taking Pearl to the concert (section M). ${ }^{123}$ These reactions relate to the wider background of change, in which all experience exhausts and finally overcomes: so Juliet's sister Margaret comments that the babies are "used up” (section A); ${ }^{124}$ and Juliet in London, months after the seduction, comments that "somehow that last play seemed to have stolen so much of my vitality”125 (section N). Juliet's collapse immediately after the seduction is the most emphasised example of this theme (section D). ${ }^{126}$

\section{Allusions}

Allusion is a "relationship" technique characteristic of Mansfield's fiction, especially in her earlier work. For example, the reference to "the Lotus Land" in 'In the Botanical Gardens’ invites the reader to consider how a well-known poem helps to illuminate the text. In that case, the allusion is via a phrase used in the poem ("the Lotos-land”). Another example of allusion, also via a phrase, is the ending of Mansfield’s poem 'To L.H.B.', written probably in 1915, which ends with the three lines:

By the remembered stream my brother stands Waiting for me with berries in his hands "These are my body. Sister, take and eat." 127

The biblical reference, altered to a personal meaning, brings the two texts (and the personages of Christ and Mansfield's brother) into a conjunction that the reader is invited to explore. In Mansfield's fiction, allusion can have the double function of suggesting the romantic or ideal while ironically contrasting with it. This use of allusion conforms to the following definition of modernist allusion:

${ }^{122}$ Ibid., p. 52.

123 Ibid., p. 63.

124 Ibid., p. 51.

125 Ibid., p. 64.

126 Ibid., p. 53.

${ }^{127}$ KM Notebooks, vol. 2, p. 29. 
The influence of literary modernism on academic research gave allusiveness another kind of credential power. It became in Eliot, in Pound, and in the way in which they in turn read Joyce, a mode of ironic distancing from the romanticism they spurned and craved ... Harold Rosenberg, in a little book on Arshile Gorky, makes this plain ... Of particular interest are his remarks on allusion, parody, and quotation, the first of these being "the most profound, the true ghostly principle of historical revival, since by allusion the thing alluded to is both there and not there." 128

In 'Juliet', this ironic distancing effect is enhanced by including allusions that do not embody the ideal: the works in question are Romeo and Juliet, Tannhäuser, and The Picture of Dorian Gray. All of these have some degree of explicit reference in the text. Allusions to them function as parallels to Juliet's experience that can be read ironically or to signify potential selves or aspects of the self.

The work with the least degree of explicit allusion is Romeo and Juliet, which is suggested merely by Juliet's name and by the fact that she is fourteen when the story opens (Shakespeare's Juliet is almost fourteen). The context ${ }^{129}$ of an unexpected first meeting between Juliet and a boy "of very much her own age”, ${ }^{130}$ who are instantly attracted to one another, strengthens the allusiveness to the background of the Shakespeare play and sets up the reader's expectations for a similar outcome of mutual, though doomed, devotion. However, the events of the story ironically diverge from those of the play. Shakespeare's Juliet has two suitors, Romeo and Paris; she remains staunchly faithful to the first and evades marriage with the other. (The mention of “Zola’s Paris”131 in section L, could perhaps be read as an oblique allusion to Juliet’s second suitor.) On the other hand, Mansfield's Juliet loves both David and Rudolf; and although both Romeo and Paris die for their love of Juliet Montague, neither Rudolf nor David is able to care long-term for Juliet Wilberforce. The play's ideals of mutual faithfulness and devotion are ironically undermined. Like her namesake in the play, Mansfield's Juliet dies at the conclusion of the work, but the two men she loved do not accompany her in death: one is abroad, and the other (together with his fiancée, Juliet's best friend Pearl) watches and even agrees to her death.

\footnotetext{
${ }^{128}$ John Hollander, The Figure of Echo: A Mode of Allusion in Milton and After (University of California Press, 1981), p. 72.

${ }^{129}$ Hollander, on p. 65, quoted later in this thesis, states the importance of context for recognising allusion.

${ }^{130}$ KM Notebooks, vol. 1, p. 50.

${ }^{131} \underline{\text { KM Notebooks, p. } 59 .}$
} 
Wagner’s opera Tannhäuser $\underline{132}$ is specifically referred to by a character. During the seduction scene (section L), in which he plays the opera's overture on the piano, Rudolf casts himself as Tannhäuser and Juliet as Venus (one of the two main female characters of the opera): "He repeated the wonderful Venus call. 'Ah, it is divine' he said. 'That is what you should be, Juliet. What - how am I for Tannhäuser.'”133 The idea that Juliet and Rudolf could indeed resemble characters from the opera is not explicitly reinforced until the final events of the story, in section $\mathrm{K}$, in which another allusion to the opera extends the parallels between the two works beyond a mere character viewpoint in the seduction scene. The allusion is the word "Thring": "Mr Thring, the porter at No. 65, gave [Rudolf] a most full, true, and particular account”"134 of Juliet’s death. “Thring” recalls Thuringia, the locality in which Tannhäuser is set, and the main female character's father, Count Hermann of Thuringia. The word alerts the reader to a further parallel in the final fragment (section $\mathrm{K}$ ), which relates that Rudolf toured Italy, Spain, and Portugal after Juliet's seduction and did not hear of her death until his return ${ }^{135}$ - linking Rudolf's journey to Tannhäuser’s pilgrimage to Rome, from which Elisabeth (the opera's main female character, who is in love with Tannhäuser) waits in vain for him to return before her death. These overtones of the opera's ending - in which the death of the saintly Elisabeth redeems the singer Tannhäuser and saves him from the Venusberg - both suggest and ironically qualify a potential ideal relationship between Juliet and the libertine artist Rudolf. Rudolf's tears on the manuscript of the "very charming little morceau" ${ }^{136}$ [sic] he composes in Juliet's memory hint at the possibility of his remorse and even repentance, but his earlier treatment of Juliet as well as the "biting irony" 137 in which these final events are related qualify such a possibility. So the possibility of a potential aspect, or self, of Rudolf is implied; its presence at the end of the story is a particular emphasis.

The third set of allusions is to Oscar Wilde's novel The Picture of Dorian Gray, which Mansfield is well known to have admired in her youth. In 'Juliet', Wilde’s writing is mentioned twice - once by Juliet and once by Pearl, who each use a quotation from it to strengthen themselves when taking unconventional steps. In section G, "The Man”, Juliet's visit to an older man who has been advising her starts with: “As she

${ }^{132}$ References to the opera's events are from Kobbé's Complete Opera Book, ed. and rev. the Earl of Harewood (London: Putnam), 1969, pp. 167-175.

${ }^{133}$ Ibid., p. 61.

${ }^{134}$ Ibid., p. 59.

${ }^{135}$ Ibid., p. 59.

${ }^{136}$ Ibid., p. 59.

${ }^{137}$ Kaplan, p. 94. 
neared the house she stopped \& repeated the Dorian Grey [sic] [...] 'This is gloriously unconventional' said Juliet, 'but I wish I was less frightened.”’138 At the end of section S, Pearl's and Juliet's decision to live together is also strengthened by recourse to Wilde: “ 'To the Devil with our Past Life' said Pearl. 'All the way here I have been quoting Oscar's "Relations are a very tedious set of people”. You know, it has been like a charm." "139 The irony of Juliet's devotion to art ironically conflicts with the fact that she is most meaningful to the men in her life not as a person or artist but briefly as inspiration for their own art. This role, as in Dorian Gray's case, ends up by destroying Juliet, since she is discarded (as Dorian fears to be) once her importance as art object is over. So Juliet is romantically and artistically important to David only in the early days of their relationship: when David is invited to perform at Juliet's house, "David was conscious of [Juliet's charm], conscious too that he had never played before as he was playing" 140 (section A). So this set of allusions functions as part of the ironic qualification rather than the ideal.

The section “The Triumph of Rudolf” recalls Wilde’s novel both in allusions and symbolism. This section, in which Rudolf wears down Juliet's resistance, has several echoes of the novel's early passage in which, between them, the artist Basil Hallward and the socialite Lord Henry Wotton, through valuing Dorian primarily as objet d'art, influence him into wishing for the portrait's unchanging youth. For example, “' 'Stop, stop’, [Juliet] said, feeling as if some spell was being cast over her” ${ }^{141}$ recalls “ 'Stop!' faltered Dorian Gray [to Wotton], 'stop! you bewilder me. I don't know what to say'”. ${ }^{142}$ Rudolf's flattering words " 'You are the most beautiful girl I have ever seen - no don’t interrupt - I shall never speak like this again [...] But you are, Juliet”’143 recalls Wotton's “ 'You have a wonderfully beautiful face, Mr Gray. Don't frown. You have.",144 Rudolf's triumphant composition after the seduction, with the repeated cry that the music inspired by the episode is his "masterpiece", 145 alludes to Basil Hallward's similar, repeated comment about his painting of Dorian (“This is going to be my masterpiece ... It is my masterpiece as it stands”"146). All of

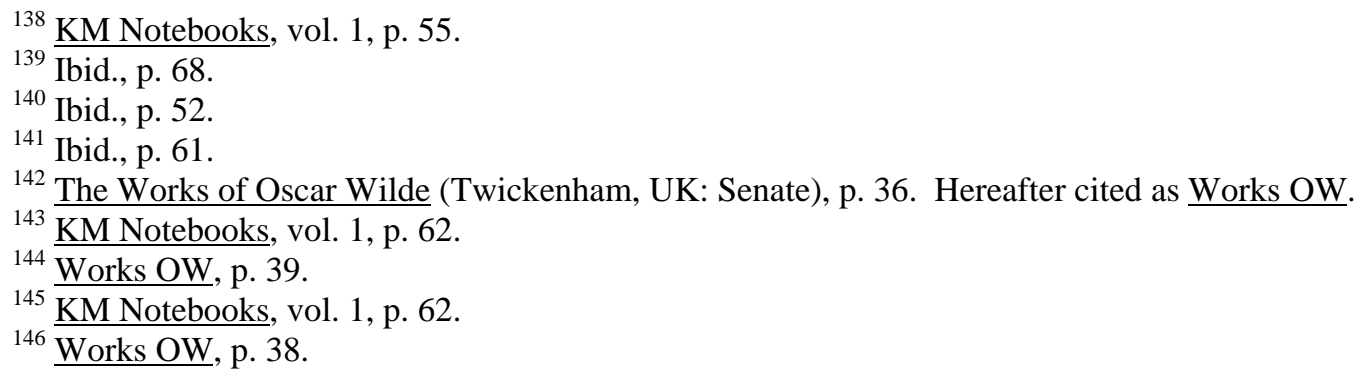


these explore "the commodification of sexual object as art object"147 or as inspiration for artistic achievement.

A key event in The Picture of Dorian Gray is Dorian's emotional destruction of a young actress, Sibyl Vane, who plays the role of Juliet in the Shakespeare play and who kills herself after Dorian leaves her when she can no longer act convincingly. The central imagery of the roses that "lay in a crushed heap on the carpet” after Juliet's seduction by Rudolf, and associated with Juliet's own fall "heavily on to the floor"148 (section D), recalls the description of Sibyl Vane lying on the floor "like a trampled flower" 149 when Dorian renounces her. This imagery of rejection contrasts with the ideals of faithful devotion and self-sacrifice suggested by Romeo and Juliet and Tannhäuser.

Like Sybil Vane, Juliet is discarded once her role is at an end. And as both Hallward and Wotton make use of Dorian, one as artist and the other as experimenter and spectator, so Rudolf exploits his experience with Juliet as artistic inspiration. Juliet's worship of art and artists leads to her being discarded like a dead flower once her exploitation for the purpose of art is over: "[The rose leaves] were once a buttonhole" said Rudolf [to David], "but it died and I threw it out of the window"150 (section M). After Rudolf's episode with Juliet, only the resulting art is important to him - an importance expressed in the clear echo of Wilde mentioned above:

Rudolf played madly, wildly, fiercely - the Music that was coursing through his veins seemed to intoxicate him. "It is my masterpiece" he shouted, closing the piano \& falling onto David's neck.

"It was my masterpiece." 151

However, this change in tense and the participle "falling" suggests that even the artist is subject to the turning wheel of change - a symbol implied by Rudolf's comment to David "I'm at the top of the whole world, \& it is rather strange." 152 His comment also links to the imagery of hill climbing (sections A and T), one of which has overtones of a fourth work.

In the key section L, melodramatically entitled "The Triumph of Rudolf”, this character’s exultant “[Y]ou shall not go now” 153 as Juliet succumbs to him itself echoes

\footnotetext{
${ }^{147}$ Kaplan, p. 31, in her discussion of Mansfield's interest in The Picture of Dorian Gray.

${ }^{148}$ KM Notebooks, vol. 1, p. 53.

${ }^{149}$ Works OW, p. 111.

${ }^{150}$ KM Notebooks, vol. 1, p. 63.

151 Ibid., p. 62.

152 Ibid., p. 62.

153 Ibid., p. 62.
} 
the words “ 'You will stay with me a little longer'”, whispered by an unnamed presence in section F:

How could she expect to keep art with her in the ugliness of her rooms, in the sordidness of her surroundings. Listlessly she raised her head \& looked round. But the room was full of cool emptiness - nothing was apparent, everything suggestive and full of charm. "You will stay with me a little longer, while I can offer you this Magic hour" whispered - ${ }^{154}$

If "life" is what whispers these words to Juliet, then Rudolf's similar expression "you shall not go now” turns “The Triumph of Rudolf” into 'The Triumph of Life', which is also the title of an unfinished poem by Shelley, ${ }^{155}$ describing life's triumphal chariot destroying and deforming the masses of human beings surrounding it. Most reminiscent of the poem is a passage in section A of 'Juliet', in which the protagonist, in a southerly gale, climbs a hill behind her house - following a dusty road or track ${ }^{156}$ that recalls the "public way/thick strewn with summer dust" ${ }^{\text {"157 }}$ with which the poet's vision of life's triumphal procession begins. The lines in 'Juliet' that most particularly recall the poem are as follows, when Juliet climbs the hills behind her house on the day after first meeting David (section A):

Down in a hollow where the gorse spread like a thick green mantle she paused to recover breath. The utter loneliness of it filled her with pleasure. She stood perfectly still, letting the wind blow cold \& strong in her face and loosen her hair. The sky was dull \& grey, and vague thoughts swept through her - of the Future, of her leaving this little island \& going so far away, of all that she knew and loved, all that she wished to be. "O I wish I was a poet" she cried, spreading out her arms. "I wish I could interpret this atmosphere, this influence." 158

The wind and Juliet's opened arms and loosened hair have overtones of the poem's description of those who lead the "wild dance” around life's triumphal chariot:

... They, tortured by their agonizing pleasure, Convulsed and on the rapid whirlwinds spun

Of that fierce Spirit, whose unholy leisure Was soothed by mischief since the world begun, Throw back their heads and loose their streaming hair; And in their dance round her who dims the sun, Maidens and youths fling their wild arms in air

154 Ibid., p. 54.

${ }^{155}$ For evidence of Mansfield's later enthusiasm for the poems of Shelley, see letter to Murry, 4 and 5 March 1918, KM Letters (O and S), vol. 2, pp. 107-108, in which she includes Shelley in "our 'special' set". ${ }^{156}$ KM Notebooks, vol. 1, p. 52.

157 P. B. Shelley, 'The Triumph of Life', in The Selected Poetry and Prose of Shelley, ed. Harold Bloom (New York and Toronto: The New American Library), p. 363, ll. 43-44.

${ }^{158}$ KM Notebooks, vol. 1, p. 52. 
As their feet twinkle; they recede, and now

Bending within each other's atmosphere,

Kindle invisibly - and as they glow,

Like moths by light attracted and repelled,

Oft to their bright destruction come and go, ... ${ }^{159}$

The overtones of these lines, which relate to sexual attraction and its destructiveness, serve as an ironic background to Juliet's excitement and awakening artistic hopes.

Section T, the last-written fragment of 'Juliet', describes Juliet's night-dream of climbing a hill; this allegory, in which Juliet's determined following of aspirations ends with disillusionment and falling, complements this early hill climb, described in A. Section T's suggestion that life is an irresistible force - a "fierce wind ... she could hardly stand against" 160 - underlies the fates of the characters in the story, who are all, even Rudolf, subject to change and sorrow: the dew on the roses that the young Juliet saw as "heavy with tears" 161 in section A anticipates Rudolf's tears on his manuscript with which the story ends.

So, in spite of their incompleteness, the fragments of 'Juliet' turn out to interrelate and to offer a reading that is satisfyingly complex. The personal drama of Juliet's aspirations, decisions, and defeat is complemented by an ironic structure and background.

The structure uses ironically paralleled scenes and unreliable character perceptions to demonstrate the destructive force of experience. In the early scenes, Juliet welcomes and celebrates that force; in a later scene, she glimpses that the world could be "diabolical”. 162 “The Triumph of Rudolf” is the structural point at which Juliet loses control; from this point on, biology and social conditioning take over, and all the characters in their different ways capitulate to them: the text is non-committal on whether even Rudolf is a true artist.

The background consists partly of the two settings to the story (Wellington and London) and partly of literary and cultural allusion. The setting-derived images of rose, wind, waves, and wheel are singled out to symbolise, respectively, Juliet's vulnerability and the forces that threaten it. Allusions to well-known works of art suggest both ideals and oppositions to them. So the potentials of self-sacrifice, devotion, and redemption (Romeo and Juliet, $\underline{\text { Tannhäuser) }}$ contrast with the forces of social, biological, and

\footnotetext{
${ }^{159}$ Shelley, p. 366, ll. 143-154.

${ }^{160}$ KM Notebooks, vol. 1, p. 69.

161 Ibid., p. 51.

162 Ibid., p. 64.
} 
artistic exploitation and consumption ('The Triumph of Life', The Picture of Dorian Gray). Tannhäuser, in particular, is used to suggest opposing selves for Rudolf (as the libertine and penitent aspects of Tannhäuser) and for Juliet (as Venus and Elisabeth); yet change qualifies all such oppositions. This modernist diversity yet unity is characteristic of Mansfield's fiction.

\section{'Brave Love'}

The episodic story 'Brave Love' was written eight years later than 'Juliet' (abandoned in January 1907); the later story was completed in January 1915, just before Mansfield went to briefly join Francis Carco in France. A diary extract for 12 January reads:

“Actually finished the story Brave Love and I don't know what to think of it even now. Read it to Jack who was also puzzled. Violent headache but rather happy”. ${ }^{163}$ A few days later, a diary extract for 17 January reads: "Yesterday I read Gordon [Campbell] Brave Love. He gave me an enormous kick about my work”. ${ }^{164}$ The story is not mentioned again in any of Mansfield's writing and was never published in her lifetime. Completed only a few weeks before The Aloe was begun (in March 1915), it provides an interesting bridge to the relationships in that story. The Katherine Mansfield Notebooks contains the most reliable transcription of 'Brave Love', which takes up twenty pages (about the same length as 'Juliet') and consists of nine sections, numbered I to IX.

Like 'Juliet', 'Brave Love' has a plot built around a love story, but it differs in giving equal emphasis to two protagonists, who have opposing viewpoints and characteristics. A brief synopsis of the plot is as follows:

I - A sailor, Mitka, on leave from his ship, arrives at the London boarding house where his brother lives with his partner, Mildred. He meets Valerie Brandon, one of the boarders, and is invited to spend the five days of his leave at the house.

II - In his first conversation alone with Valerie, Mitka agrees to be her "secret friend”.

III - Valerie and Mildred discuss Valerie’s intention to “draw [Mitka] on” as an amusement. During an excursion to a garden in the country, Mitka vows to Valerie that he will free her from Evershed, her partner.

\footnotetext{
${ }^{163}$ KM Notebooks, vol. 2, p. 4.

164 Ibid., p. 5.
} 
IV - Mitka and his brother, Paddy, discuss their contrasting views of life. Mitka's childlike rage at its simultaneous oppositions is countered by Paddy's advice that Mitka grow a "shell”.

$\mathrm{V}$ - Mitka continues to alternate elation and despair at his situation with Valerie.

VI - Mitka intends to end the friendship with Valerie but instead admits his love for her; she tries but fails to seduce him; proposing a plan to rescue and marry her after procuring money in Marseilles, Mitka fails to see Valerie’s disappointment.

VII - Mildred delivers to Valerie a letter from Mitka, who is ill in Marseilles; they discuss Valerie’s lack of interest in him, but Valerie secretly intends to visit him “just for a time”.

VIII - Still seriously ill, Mitka finally receives a letter from Valerie and experiences a sense of spiritual transfiguration before a sleep that could lead to recovery or death. Valerie enters, recoils from the sleeping Mitka and his surroundings, takes her unopened letter to him, and leaves.

IX - Valerie returns to Evershed at a nearby hotel and for the first time professes love for him.

This outline of the plot, though reminiscent of other Mansfield texts in which a woman returns to an uninteresting partner from an attempt to join someone else, gives no idea of its densely woven, multidimensional texture.

No commentators appear to have paid this story much attention, and those that have mentioned it are dismissive. Alpers (1980) considers ‘Brave Love’ as “almost a parody of her manner". ${ }^{165}$ Hankin sees Valerie's play-acting as pointing forward to that of other Mansfield characters, such as Beryl in 'Prelude', and comments that Mansfield appears to be “in league with” Valerie, never again “so self-indulgently suspend[ing] moral judgement" 166 in a story. (A closer reading allows for arguing that this is not the case.) Claire Tomalin comments that the story, "about a heartless and fascinating woman kept by a rich man, who breaks the heart of an innocent Russian sailor”, is "both artificial and melodramatic, one of her real failures”. ${ }^{167}$ Margaret Scott is slightly more positive: "It can hardly be denied that the story is, on the surface, tedious and confusing, but it nevertheless has its own importance and should be studied.”168

\footnotetext{
165 Antony Alpers, The Life of Katherine Mansfield (London: Jonathan Cape, 1980), p. 174.

${ }^{166}$ Cherry A. Hankin, Katherine Mansfield and Her Confessional Stories (London: Macmillan, 1983), p. 96.

${ }^{167}$ Claire Tomalin, Katherine Mansfield: A Secret Life (London: Viking, 1987), p. 133.

${ }^{168}$ KM Notebooks, vol. 2, p. 35.
} 
The story's basic opposition is between the naïve, inexperienced, idealistic Mitka and the various kinds of compromise with necessity, entrapment, and artifice portrayed by the other characters, especially Valerie. Using allusions to different myths (those of the archangel Michael, Circe, Parsifal, and Dorian Gray), the story suggests the characters' contrasting outlooks, motivations, and potentials, including contrasts in the same person. As in 'Juliet', the plot is ironic, since neither Mitka nor Valerie achieves their aim. The decisions made by all the characters are futile, since the background forces that have the last word drive each of them, and all their perspectives are unreliable.

As well as seeing in different ways, each of the main characters in 'Brave Love' represents a pair of concepts. Mitka represents naivety combined with a religious predisposition, and Valerie artifice combined with the forces of nature. Mitka's naivety is emphasised by the many terms used to describe his youthfulness, foolishness, and vulnerability and is supported by his extensive use of Christianity-related terms, which suggest his capacity for belief, trust, and worship. Examples of other characters’ references to Mitka’s youthfulness and vulnerability are Paddy's comment “ 'You're like a naked baby on a battlefield”,"169 and Mrs Farmer's “ 'He’ll learn soon enough. He's young'”. ${ }^{170}$ The narrator's descriptions of Mitka's appearance and behaviour often give the impression of a small boy. For example, when Mitka confesses his love for Valerie, "His eyes were full of tears and his mouth was set hard. He could not speak only nod his head; his breath came in shaking sobs". ${ }^{171}$ Similarly obvious and frequent are the religious terms Mitka uses. For example, talking to or about Valerie, Mitka three times begins with the expletive "My God", ${ }^{172}$ as if Valerie were his god. Mitka's frequent expression of his most profound experiences in terms of Christianity is probably also intended to reflect his Slavonic background (which commentators, like Tomalin quoted above, generally take to be Russian).

The opposing pair of concepts, artifice and nature, is associated with Mildred and Valerie, but of this pair the only obvious concept is that of artifice. The two women are particularly described in terms of acting, costume, and make-up: for example, the first view of Mildred shows “[h]er red lips and her beautiful painted

\footnotetext{
${ }^{169}$ Ibid., p. 46.

170 Ibid., p. 37.

${ }^{171}$ Ibid., p. 50.

172 Ibid., pp. 45, 47, 48.
} 
eyes”173 (section I), and Valerie is “wrapped in a gauze scarf and her neck and hair [...] steeped in candlelight”. ${ }^{174}$ Similarly, Mildred is aware of Valerie’s duplicitous nature and laughs at " 'you troubling to play for me”,175 as Valerie tries to disguise her reasons for manipulating Mitka’s feelings (section VII). However, Mildred is also shown as a kind of double of Valerie, first helping and then ignoring Valerie's predation of Mitka. The women's less obvious association with nature becomes clear through "relationships": Valerie, aided by and confiding in Mildred, is depicted as using artifice for predation's sake, aligned with the destructive yet attractive force of the sun.

These two pairs of concepts (naivety/religion and nature/artifice) are interconnected. The gap between the two pairs is bridged through allusions to the myths mentioned above, which as well as suggesting the characters' opposing viewpoints are associated unexpectedly and ironically with both characters; through other images, derived from the setting, that relate to both characters; and through parallel scenes suggesting forces that also affect both. These techniques invite the reader to question the nature of the two characters' identities and of the forces that drive them.

\section{Ironies of impossible choice and unreliable identity}

As in 'Juliet' and 'In the Botanical Gardens', 'Brave Love' has a drama of personal choice, but instead of making a choice between two possibilities, the two main characters of 'Brave Love' come to doubt their ability to choose; and forces that decide differently for them qualify any choices they do make. In section II, Valerie and Mitka disagree on whether choice is possible, with Mitka taking the view that “ 'If you really look yourself in the open face and say what you want to do you can do it’”, ${ }^{176}$ But by section IV, his outlook has changed to one of powerlessness: “ 'It's so impossible,' he said, 'to be torn by your head and your feet at the same time - you can't move either way.'”177 In section VI (pages 49-50), his independent choice to give up Valerie's friendship is overridden: the words “He turned” ${ }^{178}$ recall Valerie's perception of the force that rules her life: “ 'You get caught in a wheel \& round \&

${ }^{173}$ Ibid., p. 36

${ }^{174}$ Ibid., p. 37.

${ }^{175}$ Ibid., p. 52.

${ }^{176}$ Ibid., p. 41

177 Ibid., p. 46

${ }^{178}$ Ibid., p. 50. 
round you go", ${ }^{179}$ (section II). Similarly, Valerie’s choice to “ 'draw [Mitka] on”,,180 (section III) does not result in the "romantic passion" she wants, since Mitka sees their relationship in terms of the spiritual and conventional (section VI). ${ }^{181}$ At the end of section VII, Valerie decides to visit Mitka "Not really, but just for a time” because, as she tells herself, “you couldn't live up to [it]”. ${ }^{182}$ Choice is impossible for both characters, and nobody wins. ${ }^{183}$

At the same time, the possibility of choice is complicated by the contradictory, varying natures of the main characters, which is commented on explicitly. (This concept of change differs from that in 'Juliet' since the characters of 'Brave Love' embody opposing tendencies almost simultaneously rather than being gradually changed by time.) For example, in section III, Mitka sees Valerie as "Quite quite different to the girl of the morning" 184 as she joins with Mildred in teasing him; shortly before, he has seen himself as "not at all the same" as "the ... man who came here last night”185 because he now has a friend. Much of Mitka’s anguish throughout the story comes from his uncertainty as to whether Valerie has "changed" 186 towards him (section V), and Valerie points out that " 'When you think I am changed \& cold you must realize that I have to be like that"”187 (section III). The arbitrary nature of choice between different aspects of a person is suggested when Valerie, considering whether to visit Mitka in Marseilles, tries to work out the reasons for her actions: “ 'You're a perfect little thing being loving to this boy, she scolded herself, or you're degenerating - choose which one you like the better. I am sure he has'”[...]. ${ }^{188}$ Choice is arbitrary when either viewpoint is valid.

Similarly to the word "change", the word "really" is often used when identity is questioned. For example, Paddy tells Mildred, “'You're horrid tonight””; Mildred answers, “ ‘Am I? ... Am I really, Paddy?’” His answer is, “ 'Well - no - not really,' and Mitka heard the strange laugh of content that Paddy had for his woman" (section ${ }^{179}$ Ibid., p. 41.

180 Ibid., p. 43.

181 Ibid., pp. 60-61.

182 Ibid., p. 53 - the brackets are in the published text, signifying an uncertain word.

183 Other commentators have discussed Mansfield's tendency to present opposing or contradictory roles or choices in her fiction, which can be read as equally problematic and/or as ironically qualifying each other. See the articles by Kate Fullbrook and Irène Simon in The Fine Instrument: Essays on Katherine Mansfield, ed. Paulette Michel and Michel Dupuis (Sydney: Dangeroo Press, 1989), especially pp. 56 and 98.

${ }^{184}$ KM Notebooks, vol. 2, p. 44.

185 Ibid., p. 43.

${ }^{186}$ Ibid., p. 48.

${ }^{187}$ Ibid., p. 45.

${ }^{188}$ Ibid., p. 53. 
I). ${ }^{189}$ Or Mitka insists to Valerie “ ‘and you really are my friend”, 190 (section III); she confirms, “'Really””. This theme of uncertain identity is supported by imagery of oppositions in character, such as in Paddy and Valerie wearing black and white ${ }^{191}$ and Valerie being called "cold and passionate". ${ }^{192}$ The theme is also found in questioning about the nature of existence. Mitka explicitly mentions this implied doublesidedness of experience as he complains to Paddy that " 'the sweet and the bitter are such an awful mixture in Life'”. ${ }^{193}$ The title of the story derives, perhaps, from the consciousness that commitment of any kind is a risk given the instability of existence and personality.

Changes and oppositions of perspective match those of personality.

Unreliable perspective is suggested from the very start of 'Brave Love' when Mitka arrives on the scene at the beginning of section I, viewing Wyndham Square as dreamlike and unreal and then entering a house like a stage set. ${ }^{194}$ It is confirmed when Mitka's rapture over the beauty of his new surroundings is greeted with derision by members of the household, ${ }^{195}$ in the imagery of dirt and dust (for example, "the dirty bowels of the house”, ${ }^{196}$ section I), in the continuing contrast of his viewpoint with that of others, ${ }^{197}$ and by his own anguished questioning and doubting. ${ }^{198}$ Mitka's feelings alternate between bliss and despair (for example, section $\mathrm{V}^{199}$ ), and Valerie's attempts to justify her actions, even to herself, vary wildly. ${ }^{200}$ In the last resort, all the characters are either being duped or carried away by forces out of their control. Mitka's quality of faith becomes increasingly hallucinatory as the plot moves to its ending, with his statements of faith ${ }^{201}$ always qualified by his illness and Valerie's indifference. Mitka's final actions in the story ${ }^{202}$ are ambiguous, because it is uncertain why he forgets his longed-for letter from Valerie, what causes his sense of transfiguration, and whether he lives or dies (emotionally or physically). It is up to the reader to decide.

${ }^{189}$ Ibid., p. 39.

${ }^{190}$ Ibid., p. 45.

${ }^{191}$ Ibid., pp. 36 and 40.

${ }^{192}$ Ibid., p. 52.

${ }^{193}$ Ibid., p. 46.

${ }^{194}$ Ibid., pp. 35-36.

195 Ibid., pp. 37 and 41.

${ }^{196}$ Ibid., p. 36.

${ }^{197}$ Ibid., pp. 41and 46.

${ }^{198}$ Ibid., pp. 46, 48, and 49.

${ }^{199}$ Ibid., pp. 47-49.

${ }^{200}$ Ibid., pp. 41, 43, and 53.

${ }^{201}$ For example, ibid., p. 53.

${ }^{202}$ KM Notebooks, vol. 2, pp. 54-55. 


\section{Allusions}

In 'Juliet', allusions suggesting a literary and mythical background to the story were all supported by various kinds of references to titles. In 'Brave Love', there are no references to or suggestions of titles, either by the narrator or the characters. Instead, allusion relies on the more covert means of character names, phrasal echoes, and literary events and motifs. This usage corresponds to Abrams' definition of allusion as “a passing reference, without explicit identification, to a literary or historical person, place, or event, or to another literary work or passage”. ${ }^{203}$

Allusion to different texts in 'Brave Love' associates the characters with different possibilities. This adds to the fragmented nature of the text as well as allowing exploration of the characters in a short space of time. Associating the characters with contrasting mythical figures reinforces the characters' sense of the binary. All the characters' contrasting and varying views, and the dimensions that the characters are related to, are allowed to coexist, with none given precedence over the other. In the final analysis, the choice of viewpoint is left up to both reader and character.

(Mansfield's tendency to see identity in terms of opposing potentials is expressed in a letter of 10 February 1920 from Mansfield to John Middleton Murry, in which she explains that she sees him in terms of a "bright burning angel" hidden behind a "dark self":

But I always felt that behind all that talk - "I am very tired" a quoi bonisme there hid - what I can't help calling a bright burning angel - loving, turned to the light ... But the war came - your dark self pulled over, and finally at the Casetta you said you did not even want the angel to triumph ... I adore you as you are - your deepest self, but yes it is the "angel" I adore and believe in for ever. $^{204}$ )

\section{The Archangel Michael}

Mitka's naivety and religious outlook are expressed and qualified by allusions to the myth of the archangel Michael in Revelations 12 (verses 1-17), ${ }^{205}$ suggested by Mitka's name (as diminutive of Michael) and his momentary perception of himself as

\footnotetext{
${ }^{203}$ Abrams, p. 9.

${ }^{204}$ KM Letters, vol. 3, p. 215.

205 Since Mansfield would most probably have used an Authorized Version of the Bible, biblical quotations are taken from a mid- $20^{\text {th }}$ century Authorized Version, although it might differ slightly from Mansfield's due to later revisions.
} 
a saint. $^{206}$ (In the Christian church, Saint Michael is derived from this figure.) Revelations 12 is a mythical account of a war in heaven between the archangel Michael and his angels against the dragon, Satan, who threatens to devour, as soon as it is born, the baby of a pregnant woman "clothed with the sun". The woman gives birth, the baby is "caught up to God", the woman escapes to "a place prepared of God”, 207 and Michael casts the dragon out of heaven. In 'Brave Love', elements of this myth are associated with Mitka's perspective of himself as hero (corresponding to the archangel), Valerie as radiant being in need of rescue (the woman clothed with the sun), and Evershed as villain (the dragon/Satan). At the same time, an ironic use of those same elements associates Mitka with the newborn baby and the dragon/Satan, and Valerie also with the dragon. This varying use of association both suggests Mitka's elevated (and melodramatic) view of the circumstances and ironically conveys his naivety, vulnerability, and anger as well as Valerie's different nature from Mitka's view of her. Yet the different ways in which the characters see each other suggests opposite potentials.

The main allusions to Revelations 12 are as follows. In section I, when Mitka first sees Valerie, she is “all wrapped up in a gold net of quivering candle light” ${ }^{208}$ - a diminishment of being “clothed with the sun”. In section III, hearing Valerie's version of her relationship with Evershed, Mitka says to her, “ 'But surely, surely ... there's some place that you can get away’”, 209 suggesting the woman's flight “into the wilderness, where she hath a place prepared of God”. ${ }^{210}$ Referring to Evershed, Mitka says melodramatically, “ 'To hold you in his power like that. My God! ... What a devil this man must be.”” He also asks (casting himself as hero), “ 'How am I going to free you?'”

Contrasting ironically with Mitka's melodramatic view of himself as hero are the text's frequent references to him as baby or boy, which suggests the newborn baby that the dragon waits to devour in Revelations 12, for example, Paddy's “ 'You're like a naked baby on a battlefield'",211 (section IV). Similarly, Mitka in his moments of despondency is associated with aspects describing the devil in Revelations 12: having no "place ... in heaven”, "having great wrath”, and knowing “that he hath but a short

${ }^{206}$ KM Notebooks, vol. 2, p. 54.

207 These quotations are from verses 1,5 , and 6.

${ }^{208}$ KM Notebooks, vol. 2, p. 37.

209 Ibid., p. 45.

210 Verse 6.

${ }^{211}$ KM Notebooks, vol. 2, p. 46. 
time”. ${ }^{212}$ So “There is no place for me, thought Mitka”"13 (section V); “ 'I have been crying with rage!'”214 (section IV); and "That is like a clock in me - five days, five days, \& then I am gone”,"215 (section III). Similarly, “ “This is no place for me”,216 says Valerie (section II), who more strikingly suggests the dragon in her propensity to devour the child sacrifice of Mitka. ${ }^{217}$ This association ironically contrasts with Mitka’s view in section VI of Valerie as radiant and saintly. ${ }^{218}$

Throughout the story, Mitka attempts to drive his relationship with Valerie in a way that suggests the biblical myth, which is ironically devalued by Valerie. The situation of the woman's fleeing "into the wilderness, where she hath a place prepared of God”219 is suggested by Mitka's preparation of a place for Valerie to escape to in Marseilles. Valerie does consider going to Marseilles “just for a time”220 (section VI), which recalls the words "for a time" in verse 14: "And to the woman were given the wings of a great eagle, that she might fly into the wilderness, into her place, where she is nourished for a time ...”. (The wings are seen on Mildred's "blue silk kimono embroidered in white wings"221 [section I].) The concept of the "place” is ironically devalued in Valerie's disgusted comment in section VIII: "So this was where he expected her to come - it was to this place."222 The ironic diminishments of this myth reflect Mitka's inability to realise his ideal outcome. Yet at the same time a foreshadowing of Mitka’s fate jokingly validates Mitka’s terms of reference: the imagery his brother Paddy uses in closing his discussion with Mitka in section IV suggests that God will return Mitka to the state of his previous life, perhaps through death:

“Oh Mitka," laughed Paddy, "if I sit here any longer with you a long white beard will flow over my chest. You make me feel hundreds of years old. I think I'd better shut you up in a box \& take you back to your ship again., 223

\footnotetext{
${ }^{212}$ Verses 9, 8, and 12.

${ }^{213}$ KM Notebooks, vol. 2, p. 47.

214 Ibid., p. 46.

${ }^{215}$ Ibid., p. 44.

${ }^{216}$ Ibid., p. 40.

${ }^{217}$ Ibid., p. 43.

${ }^{218}$ Ibid., p. 50.

${ }^{219}$ Verse 6.

${ }^{220}$ KM Notebooks, vol. 2, p. 53.

${ }^{221}$ Ibid., p. 39.

${ }^{222}$ Ibid., p. 55.

${ }^{223}$ Ibid., p. 47.
} 


\section{Circe}

Valerie's and Mildred's artifice and predation are suggested through references to the classical myth (related in Ovid's Metamorphoses and Homer's Odyssey) in which the enchantress Circe transforms Odysseus' sailors into pigs. Possibly because of the many different translations of these works, the allusions to this myth rely on event and associated motif rather than direct phrasal echo. An opening passage of 'Brave Love' echoes the beginning of the Circe story. In section I of 'Brave Love':

As [Mitka] came to number "34" he heard the sound of a piano and then Mildred West's voice floated to him [...] Ah, thought Mitka, she is singing to my brother [...] And he ran up the steps and gave the bell a pull that sent the German waiter rushing up from the dirty bowels of the house. Before Mitka had time to ask for his brother he heard Mildred's voice from the drawing room landing. "Who is there? Hans, who is it?" Mitka ran into the hall past the German waiter and shouted gaily, "It is I, Mitka."

"Mitka!" Mildred sounded very pleased. She came rustling down the stairs [...] and into the hall [...] "Come up to the drawing room," she said, laughing at him. ${ }^{224}$

In the Odyssey:

And now, before the Goddess' gates arrived, They heard the voice of Circe singing sweet [...]

Thus then Polites ... the rest bespake.

Ye hear the voice, comrades, of one who weaves

An ample web within, and at her task

So sweetly chaunts that all the marble floor

Re-echoes; human be she or divine

I doubt, but let us call, that we may learn.

He ceased; they call'd; soon issuing at the sound,

The Goddess opened wide her splendid gates,

And bade them in; they, heedless, all complied [...]

She, introducing them, conducted each

To a bright throne, then gave them Pramnian wine, With grated cheese, pure meal, and honey new, But medicated with her poisonous drugs [...]

She gave them, and they drank, -

When, smiting each with her enchanting wand, She shut them in her sties. ${ }^{225}$

Common to the two texts are the motifs of the sailor(s) outdoors hearing a woman singing inside the house and his or their calling out to her; she emerges and invites her visitor(s) in.

${ }^{224}$ Ibid., p. 36.

${ }^{225}$ The Odyssey of Homer, trans. William Cowper (London: Dent), first published in this edition 1910, pp. 146-147 (Book X, ll. 271-295). 
The Mansfield text further alludes to motifs from the story of Circe above. At the end of section I, ${ }^{226}$ Mitka accepts wine first suggested by Mildred. ${ }^{227}$ The wine is associated with Mitka’s elation, especially with regard to Valerie. Mrs Farmer, Mildred's mother, points out the suspect nature of such a drink (before it is offered): “' 'You just wait a bit before you're so pleased with the outside of the glass.",228 The honey that Circe offered the sailors is alluded to in section III, also relating to intoxication, as Mitka, by now in love with Valerie, takes part in an excursion into the country: "The scent of [hay] was in the air like honey. I feel a little drunk, thought Mitka. I wonder is this country really what I see? If so it is the most beautiful -” 229

The pig motif has a strong presence in the Mansfield text, associated with Mitka’s recurring disillusionment and with Valerie’s intention to “sacrifice” him. For example, in the Sunday dinner scene in section V, which Mitka finds "all so ugly",230 Mildred tells her mother off for making "a piggy mess” of herself. The pig image recurs in section VII (p. 52) as Mildred and Valerie discuss Mitka’s letter:

There were pages \& pages of fine careful writing. "Like to hear?” [Valerie] said, making a face at Mildred. But Mildred moved away from the bed. "No, no. I loathe hearing things being killed $-\&$ babies cry worse than pigs. Bon appetit, you little witch.” 231

The implication is that “ 'Mitka's to be sacrificed”"232 (section VII) and eaten by the "little witch" (various sources describe Circe as a sorceress and a goddess). The concept of child sacrifice qualifies Mitka's religious adoration of Valerie. The pig motif also acts as a commentary on Valerie herself, implying that she sees Mitka only in terms of flesh.

The pig motif is suggested again close to the end of the story (section VII), when Valerie finds and then abandons the sleeping Mitka; here, the image of the slop pail strengthens the possible association with pigs (conveyed, along with the impression of childishness, by Mitka’s pink lips and ears); the slop pail also implies her repugnance:

That was how she found him. An African servant with a slop pail had met her at the bottom of the stairs, had struggled in front of her up the five flights, the stinking pail still in her hand. Valerie opened the door and came in - quite

${ }^{226}$ KM Notebooks, vol. 2, p. 39.

227 Ibid., p. 38.

${ }^{228}$ Ibid., p. 38.

${ }^{229}$ Ibid., p. 44

${ }^{230}$ Ibid., p. 47.

${ }^{231}$ Ibid., p. 52.

${ }^{232}$ Ibid., p. 43. 
quietly. But when she saw Mitka lying on the bed she ran over to him - terribly frightened for a moment. No - nothing like that had happened. He was only sound asleep, his face covered with beads of sweat, lying on his back, his lips and his ears very pink. Had she dreamed this. But not this disgusting dreadful room, not this vile house, that awful African woman, the smells. ${ }^{233}$

The pig implications in Valerie's view of the situation, combined with the carnations she carries in this scene ("carnation" is derived from the Latin word caro, meaning flesh $^{234}$ ), strengthen the merely physical implications of her outlook. This perspective contrasts with Mitka's transfigured view earlier in the same section - a treatment that qualifies both views.

\section{$\underline{\text { Parsifal }}$}

Allusions to another myth, that of Parsifal in the opera of that name by Wagner, supports Mitka’s self-assigned role of spiritual rescuer (as in Revelations 12) and Valerie's of seductress with magical powers of artifice (as in the Circe myth). These allusions relate to the ideal of spiritual redemption. 'Brave Love' has many echoes of the opera, recalling either elements of the stage directions or phrases sung by the characters. Only the most obvious can be mentioned here.

Mansfield's enthusiasm for Wagner can be inferred from various notebook jottings from her early years, such as the possible quotations from Symons, around 1908, noted on page 31 of this thesis, and the following extract from a letter to Mansfield's sister Vera (19 June 1908):

There is a fascination almost unequalled in collecting all the details of a man's life - studying his portrait - his work [...] I have R.L.S. and Dante Gabriel Richard Wagner \& Jimmy Whistler - all the Brontes - countless others haven't you? ? $^{235}$

A jotting of Mansfield's intention, late in1921, to write a story involving Wagner's music is "Aunt Anne. Her life with the Tannhäuser Overture." 236 The explicit references to Tannhäuser and Wagner in 'Juliet' also demonstrate Mansfield's interest in Wagner.

\footnotetext{
${ }^{233}$ Ibid., p. 53.

${ }^{234}$ The association of carnations with flesh (this time Valerie's own) is reinforced by an earlier passage (section VII, p. 53) in which Valerie imagines buying them in Marseilles: "But Marseilles. Well - and maybe I can buy white carnations from a dark musky-smelling flower seller who could not keep his eyes off her whiteness.” This association could also imply that Valerie's flesh is for sale.

${ }^{235}$ KM Letters, vol. 1, p. 51.

${ }^{236}$ KM Notebooks, vol. 2, p. 297.
} 
There is no evidence that Mansfield ever attended a performance of Parsifal, or indeed of any work by Wagner, but of the three operas mentioned in her notebook around 1908 ("Parsifal - light; Tristan - sea; Ring - fire"237), it is interesting that Parsifal is the first-mentioned and is related to the element of light, since a possible allusion to the opera in 'Brave Love' uses imagery of light. A further reason for Parsifal allusions in 'Brave Love' could be that the time of the story's completion (12 January 1915) approximately coincides with much public interest about the opera, since 1914 was the first year in which it could be performed anywhere in Europe except Bayreuth; during 1914 it was performed “in virtually every major European capital from St. Petersburg to Madrid.”238 Although the opera’s performance was restricted before 1914, the music publisher Schott of Mainz, which had branches in London, Paris, and Brussels, issued a piano version of the score, with text in German and English and a copyright date of 1902. Mansfield had studied German at school and had lived in Germany, so she knew the language well and would not have relied on the ornate English translation of, say, the Schott translation of the libretto; for this reason I am using a modern translation below, which reproduces the German more faithfully.

As Hollander states in The Figure of Echo, context is important for recognising allusion:

The reader of texts, in order to overhear echoes, must have some kind of access to an earlier voice, and to its cave of resonant signification, analogous to that of the author of the later text. When such access is lost in a community of reading, what may have been an allusion may fade in prominence; and yet a scholarly recovery of the context would restore the allusion, by revealing an intent as well as by showing means. ${ }^{239}$

Allusions to Parsifal are possible because they link similar situations in the opera and the story. The echo that might first alert the reader to such allusions is the phrase "a Mother's blessing”, used by Mildred as she farewells Mitka from Wyndham Square (section VI):

"Oh well,” said Mildred, “a Mother’s blessing. Run along. I must dress. I shan't see you again, shall I?” She had been having breakfast in bed \& she had called to Mitka to come \& say goodbye. "No, I suppose not.”

${ }^{237}$ KM Notebooks, vol. 1, p. 214. These could be jottings from Arthur Symons.

${ }^{238}$ Robert Gibson, 'Guardians of the Grail: Keeping Parsifal for Bayreuth' in Parsifal programme for 17 and 19 March 2006, Michael Fowler Centre, Wellington, p. 23.

${ }^{239}$ Hollander, pp. 65-66. 
“Run along and say goodbye to your little sweetheart,” said Mildred. ${ }^{240}$

Since Mildred has been jokingly playing the role of Mitka's mother, is farewelling him possibly for the last time, and is directing him to Valerie (who will try to seduce him), the phrase "a Mother's blessing” and the situation recall the phrase's use in Act II of Parsifal. There, in the garden of the enchanter by whom she is controlled, Kundry attempts to seduce Parsifal with a kiss that she says is the last blessing sent by his dead mother:

"Die Leib und Leben einst dir gegeben, [...] sie beut dir heut, als Muttersegens letzten Gruss, der Liebe - ersten Kuss."241 / "She who gave you life offers you today this last greeting of a mother's blessing, the first kiss of love!”242

The kiss follows in the opera's stage directions: "Sie ... heftet nun ihre Lippen zu einem langen Kusse auf seinen Mund.”243 / "She ... presses her lips to his in a long kiss.”244 Shortly after Mildred has sent him to her, Mitka capitulates to Valerie in another long kiss that, like that of Parsifal and Kundry, remains the only one: "In that long kiss Mitka gave himself and his brave love and his hopes and all his being into the keeping of Valerie.”245 The reader, in comparing Mitka's emotional but not physical capitulation to Valerie with Parsifal's resistance to Kundry, is invited to question the nature of Mitka’s surrender.

There are other echoes of the garden scene in the opera. For example, Kundry’s calling Parsifal by his name ("Riefest du mich Namenlosen?”246/ "Did you call me, the nameless one?" ${ }^{247}$ ) is alluded to during the garden scene (section III) of 'Brave Love': "His heart gave a great thud when she spoke his name. 'First time you ever call me by my name is under this tree,' he said.”248 Also, Mildred and Valerie both wear veils on the excursion to the garden (section III): Mildred has a "blue veil”, ${ }^{249}$ and in the car, “the faint breeze flutter[s] [Valerie’s] long purple veil”250. This recalls the flower maidens, who are “mit flüchtig übergeworfenen, zartfarbigen

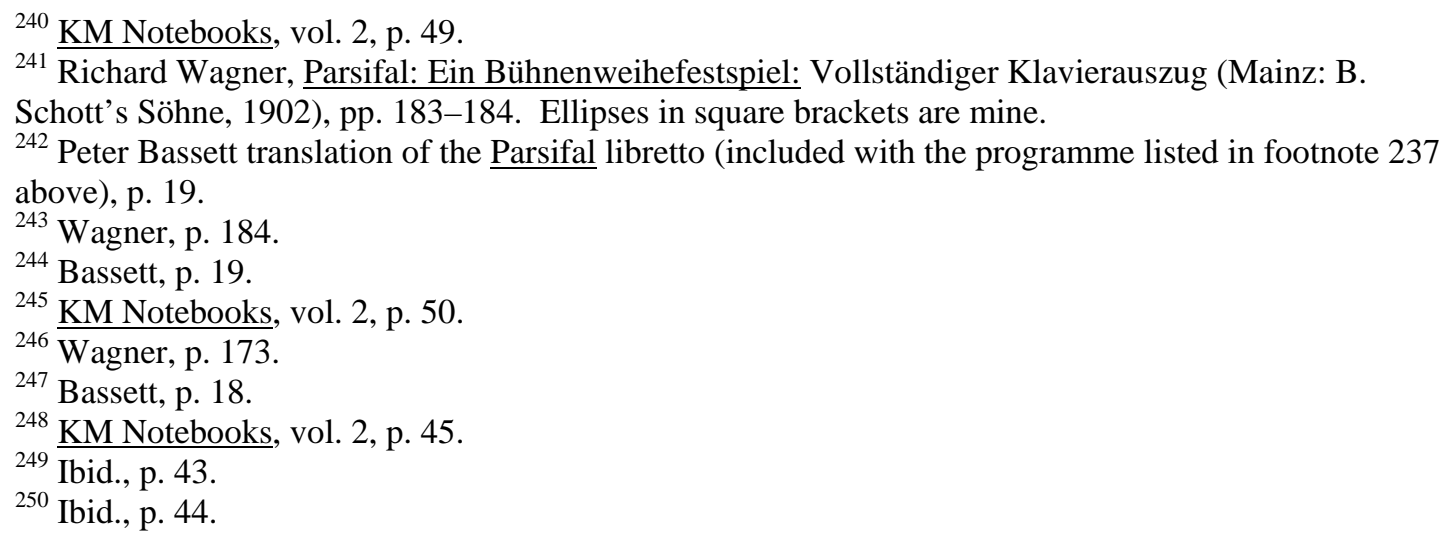


Schleiern verhüllt" 251 / "draped in veils of soft colours”. ${ }^{252}$ These links between the enchanter's garden and the one in section III, where Mitka pledges himself to rescue Valerie from Evershed, deepen the mythical suggestiveness of the situation, since Valerie apparently in Evershed's power recalls Kundry as tool of the wicked enchanter, Klingsor, and leads to questions about the forces that control Valerie.

The penultimate section VIII, in which Mitka appears for the last time, also has possible allusions to $\underline{\text { Parsifal, }}$ which strengthen the suggestion of spiritual forces visible to the seriously ill Mitka. These resemblances are to stage directions in Act I of the opera, in which Parsifal first views the Holy Grail. Parsifal's physical reactions to seeing the grail and empathising with the pain of the wounded king, Amfortas, are those of standing motionless and silent for a long time, much of that time with his hand on his heart. So "Parsifal bleibt aber, starr und stumm, wie ganzlich entruckt, zur Seite stehen.”253 / "Parsifal remains standing, motionless and silent, as if completely transported."254 Also:

Parsifal hatte bei dem vorangehenden stärksten Klagerufe des Amfortas eine heftige Bewegung nach dem Herzen gemacht, welches er kramphaft eine Zeitlang gefasst hielt. ${ }^{255}$ / Parsifal, on hearing Amfortas's loud cry of agony, had made a violent movement towards his heart, which he clutched convulsively for a long time. ${ }^{256}$

The motifs of standing in a spiritual transport and of pressing hand to heart are combined in VIII:

[Mitka ...] shut the door, leant against it, the letter pressed to his heart. There was a piece of mirror on the wall opposite the door. As he raised his eyes he saw himself reflected in it, so transfigured, so mysteriously joyful. Mitka is dead, he thought. Mitka is a saint. For a long time he stood there. And a strange thing happened. He forgot all about the letter that lay on his heart. With wondering eyes he looked at his little room $[\ldots]^{257}$

Another motif, of a ray of light illuminating the grail, is as follows, and this is what Parsifal has seen as he stands "completely transported":

Hier dringt ein blendender Lichtstrahl von oben auf die Krystallschale herab; diese erglüht sodann immer stärker in leuchtender Purpurfarbe, alles sanft bestrahlend. $^{258}$ / Here a dazzling ray of light falls from above on the crystal

${ }^{251}$ Wagner, p. 126.

252 Bassett, p. 14.

${ }^{253}$ Wagner, p. 92.

${ }^{254}$ Bassett, p. 10.

${ }^{255}$ Wagner, p. 100.

${ }^{256}$ Bassett, p. 11.

${ }^{257}$ KM Notebooks, vol. 2, p. 54.

258 Wagner, p. 90. 
chalice which now glows a brilliant purple, shedding a soft light on everything. $^{259}$

This is reflected in section VIII: "On a shelf by the bed there were bottles - bottles of all colours. A pencil ray of sun shining on these bottles made them wonderfully beautiful."260 The importance of the bottles as part of Mitka's ecstatic vision is stressed at its end: "He felt very peaceful, almost as if he were at sea again. Yes, his little room with the spots of sun and beautiful bottles floated in the sea [...]"261

The effect of these echoes of this opera (which celebrates the triumph of spiritual power) is to validate Mitka's sense of transfiguration at the same time as his vision is qualified by the context of illness, dream, and Valerie's contrasting perspective. Similarly to the way in which 'Juliet' concludes by contrasting the references to Tannhäuser with the narrator's cynical tone, here Mitka's sense of transfiguration (with resemblances to Parsifal's seeing the grail) is juxtaposed with Valerie's view of the same scene as ugly: "She saw the red \& blue bottles, the ugly blobs of sun spilling through the broken blind." ${ }^{262}$ Mitka's religious viewpoint (with overtones of Parsifal as the fool) is contrasted with Valerie's carnal one (with overtones of Kundry as seductress). At the same time, the opera's portrayal of Parsifal and Kundry as each a combination of opposites (fool/redeemer and seductress/servant or penitent) supports the fragmented portrayal of the foolish Mitka and deceitful Valerie, implying an ideal other self that each character might possibly have achieved (those of redeemer and redeemed). The final set of allusions deepens the contrasting implications of corruption in Valerie’s actual, most dominant self.

\section{Dorian Gray}

Allusions to The Picture of Dorian Gray support the concepts of artifice and nature and so mainly give significance to the characteristics of Valerie. In the opening section of 'Brave Love', Valerie's playing "soft muffled chords”263 on the piano and then playing with a "red and grey parrot”264 recall the penultimate chapter of Wilde’s novel (shortly before Dorian's death), in which Lord Henry strokes a pink and grey parrot, and

\footnotetext{
${ }^{259}$ Bassett, p. 10.

${ }^{260}$ KM Notebooks, vol. 2, p. 54.

261 Ibid., p. 54.

${ }^{262}$ KM Notebooks, vol. 2, p. 55.

263 Ibid., p. 37.

${ }^{264}$ Ibid., p. 38.
} 
Dorian plays "some soft chords on the piano". ${ }^{265}$ These allusions associate Valerie with the depraved Dorian Gray and the detached, cynical Henry Wotton, suggesting Valerie's resemblance to the two characters - a resemblance borne out during the story in the contrast between Valerie's youthful appearance and her actual nature (as with Dorian) and in Valerie's exploitation of others for her own amusement (like Wotton's).

In section VII of 'Brave Love’:

One morning a few weeks later Mildred walked into Valerie's room. The young girl was in bed and asleep. Mildred stood looking down upon her and wondering in a vague way how or why Valerie kept her childishness of appearance [...] Yes, she's lovely! thought Mildred. Good Lord how innocent she looks. I expect she's as passionate a little devil as they make them [...] She's so certain of herself and so utterly careless, and yet she keeps her secret. $^{266}$

As she observes the sleeping Valerie, Mildred's contrast between Valerie's childlike, innocent appearance and her “secret” recalls Dorian Gray’s beautiful yet deceptive youthfulness. Later in the same section, Valerie left alone implies what the secret is:

[Mitka would] be an awfully charming lover [...] But you couldn't live up to [it], my child, she said, staring at herself in the glass. Because, you see, my lady, that's what's the matter with you. Her lips smiled gaily, but her eyes said Yes, that is true - you're too clever to be found out, but you'd kill him, you know you would - and oh what complications! You're a perfect little thing being loving to this boy, she scolded herself, or you're degenerating - choose which one you like the better. I am sure he has $[\ldots]^{267}$

Valerie's thoughts here suggest that if she were to stay with Mitka, she could not keep up her role for long. Whether that problem or some other "secret" is what would "kill" Mitka is left to the reader to imagine. This lack of clarity is in line with the characters' repeated questioning about what is "really" the case (discussed on page 44). The above quotation is also an example of Valerie's fascination with mirrors. In this example, her awareness of the contrast between her appearance and her inner self resembles Dorian Gray’s similar awareness:

[Dorian] would ... stand, with a mirror, in front of the portrait that Basil Hallward had painted of him, looking now at the evil and ageing face on the canvas, and now at the fair young face that laughed back at him from the polished glass. The very sharpness of the contrast used to quicken his sense of pleasure. ${ }^{268}$

\footnotetext{
${ }^{265}$ Works OW, pp. 248-249.

${ }^{266}$ KM Notebooks, vol. 2, p. 51-52.

267 Ibid., p. 53.

${ }^{268}$ Works OW, p. 155.
} 
Like the two sides of himself that Dorian confronts, the two sides of herself that Valerie sees in the first quotation above are an outer self that is an object, a "thing", that appears perfect, and an inner self that is “degenerating”. So Valerie's more realistic viewpoint than Mitka's is qualified by intimations of corruption.

Allusions to The Picture of Dorian Gray also support the concept of nature, which (like artifice) is represented by Mildred and Valerie. In section II of the story, Mitka states his idealistic view that beautiful women " "are the spirits of nature’” in that " "nature reflects herself in them as she does in ponds or flowers"”. ${ }^{269}$ On one level, this remark ironically contrasts his ideal view of their beauty with the actual artifice that they use to enhance it. On another level, though, he is expressing a truth that he is unaware of: that nature is cruel and remorseless, and these women are indeed reflecting those qualities in their natural wastefulness, destructiveness, and deceit. Throughout the story, Valerie's ruthlessness is suggested in her repeated destruction of flowers, which recalls Henry Wotton's examining a daisy and then pulling it to pieces to accompany a cutting opinion: “' 'Yes; she is a peacock in everything but beauty,' said Lord Henry, pulling the daisy to bits with his long, nervous fingers." ${ }^{270}$ Like the roses associated with Juliet to suggest her vulnerability, those of damaged flowers imply Valerie's power to destroy. In her first conversation alone with Mitka (section II), she eats a geranium head and throws away the stalk. ${ }^{271}$ In the second (section III), she plays with and discards fallen blossoms; ${ }^{272}$ and in her bedroom in section VII is "a big bunch of bruised yellow roses”. ${ }^{273}$ Finally, in her visit to Mitka in Marseilles, she "even took care to see that the petals of her flowers had fallen”274 (section VIII). Valerie expresses this same tendency as follows: “ '[I]f once I've touched a thing I can't let it go until I've tried to break it or to see if it can break me. It's my one principle - snatched from a weary world -,„275 (section VII). Paradoxically, Valerie combines artifice and the predation of nature. At the same time, the flower expresses Mitka's vision of an ideal life married to her ("Life unfolded like a sweet flower as he spoke. He smelled its fragrance, he leaned over it and the dazzling miracle of its beauty \& colour intoxicated him”276 - section VI).

${ }^{269}$ Ibid., p. 40.

${ }^{270}$ Works OW, p. 23.

${ }^{271}$ KM Notebooks, p. 41.

272 Ibid., p. 44-45.

${ }^{273}$ Ibid., p. 52.

${ }^{274}$ Ibid., p. 55.

${ }^{275}$ Ibid., p. 52.

${ }^{276}$ Ibid., p. 51. 
Valerie's predatory nature is also connected to her need for entertainment, which she proposes to achieve by her exploitation of Mitka. This need is similar to Henry Wotton's interest in Dorian primarily as a spectacle, expressed in passages such as:

It was delightful to watch [Dorian]. With his beautiful face, and his beautiful soul, he was a thing to wonder at. It was no matter how it all ended, or was destined to end. He was like one of those gracious figures in a pageant or a play, whose joys seem to be remote from one, but whose sorrows stir one's sense of beauty, and whose wounds are like red roses. ${ }^{277}$

When Mitka first meets Valerie (section I), she foreshadows her role with Mitka by taking the parrot out of its cage and playing with it, emphasising that " 'It amuses me.”,278 In discussing Mitka with Mildred in section III, Valerie makes it clear that a relationship with Mitka would be to relieve her ennui:

"But Mildred I'm so bored bored bored! You know as well as I do I've never been in love with Evershed and he knows it too [...] I'm seeking for a romantic passion ...”

“And Mitka’s to be sacrificed,” said Mildred shrewdly. ${ }^{279}$

In one way, the parrot removed from its cage represents Mitka set free by Valerie from his protection of loneliness (a "relationship" developed in section IV, in which Mitka explains that loneliness has been his protective "shell" ${ }^{280}$ ). The parrot also represents Valerie's consciousness of herself as entrapped animal available to be played with, as she makes clear by her suggestive comments to Mitka in section I, such as " 'Would you like to nurse the pretty parrot?",281

So images of flower and parrot, originating from the Dorian Gray story, link the two main characters through implications of artifice, predation, and play. In fact, all four myths alluded to in this story repeat a similar pattern of predation (usually combined with artifice) but perhaps with different outcomes: in the orginal versions, the Circe/sailors and Wotton/Gray pairs show successful victimisation, whereas the dragon/woman and Kundry/Parsifal pairs show predation that does not succeed, due to spiritual strength. In 'Brave Love', the ironic and fragmented allusions to the myths leave the outcome of Valerie's predation of Mitka uncertain.

${ }^{277}$ Works OW, p. 78.

${ }^{278}$ KM Notebooks, vol. 2, p. 38.

${ }^{279}$ Ibid., p. 43.

${ }^{280}$ Ibid., pp. 46-7.

${ }^{281}$ Ibid., p. 38. 


\section{Setting-derived images}

The myths discussed above mainly relate to one or the other character and that character's viewpoint, although the myths can be fragmented to refer to both. Simultaneously, other techniques are used to connect the two characters, such as the parrot and flower images discussed in the section immediately above.

A further key image is that of the wheel, given explicit meaning by Valerie in the context of freedom and necessity. In section II, Valerie expresses her admiration for Mitka, telling him that he " 'looked really \& truly free”" when he arrived the previous evening, and Mitka answers, “ 'That's quite true [...] Yes, I am.”,282 Valerie says that " 'there is only one thing. To get free \& to keep free”" but uses the image of the wheel (similar to the one in 'Juliet') to describe her more actual reality of necessity: “ 'You get caught in a wheel \& round \& round you go."”283 Moments later, Mitka too gets caught in the wheel as he offers his help (and implicit devotion) to Valerie, who responds with mingled "relief and scorn and amusement" as she recognises that his freedom has been short-lived. The wheel image is connected to the setting via Mrs Farmer's bath chair, suggesting Valerie's perception that necessity rules from babyhood to old age:

“[...] What on earth am I talking like this for. It's such nonsense, such hopeless nonsense," [Valerie] cried desperately. "There's old Mrs Farmer down there going tata in a bath chair. She's seen us. Wave your hand to the baby.”284

Valerie's comment about being caught in a wheel is the only explicit mention of that image, apart from Mitka's following retort, “ 'I don't believe in wheels.”,285 However, association is used to link both these characters to the wheel concept, using terms of wheeling and turning - suggesting a slow but inevitable process of change for both. Valerie's and Mitka's initial attraction to one another is shown in such images in section I. So Valerie "wheeled round on the piano stool, facing them", and she "slowly turned and smiled at Mitka”. ${ }^{286}$ Mitka’s moment of total surrender to Valerie in section VI is marked by the irresistible impulse to " 'turn"”:

"The thing to do," he said, speaking slowly, "is for me to say my goodbye and then to go. Goodbye, just like that. Not turn.” He turned and looked at her \& the words died on his lips. ${ }^{287}$

\footnotetext{
${ }^{282}$ Ibid., p. 42.

283 Ibid., p. 41.

${ }^{284}$ Ibid., p. 42.

${ }^{285}$ Ibid., p. 41.

${ }^{286}$ Both ibid., p. 38.

${ }^{287}$ Ibid., p. 50.
} 
The fact that the turning process also applies to other characters is indicated by Evershed's “ 'You've given me a pretty turn”,288 in the final section, when Valerie rejoins him in Marseilles. His comment suggests that at this point, Valerie is turning the wheel. The final line of the same section uses a similar term as Evershed expresses his relief at Valerie's profession of love for him: “ 'I knew you'd come round, little girl.",289 So the wheel ends the story and implies that Valerie is now being turned on it. This emphasis on the wheel at the story's conclusion (suggesting the wheel of fortune, Buddhist wheel of life, or even the Catherine wheel, on which Christian saints were martyred) acts as a counterstatement to the Christian implications of the allusions to Parsifal, also close to the story's end.

A similar concept to being turned on a wheel is that of drawing and being drawn, which also affects both characters. This concept also links to the sun image, which is common to the setting and two of the myths. Planning her entrapment of Mitka in section III, Valerie comments to Mildred, “' I'll draw him on.”290 She goes on to surmise that “ 'perhaps it's the hot weather's brought things to a crisis with me. I'm seeking for a romantic passion ...”,291 That is, she in her turn is being driven by the sun. The drawing power of the sun is made clearer by the end of the scene in which Mitka and Valerie sit outdoors on Sunday afternoon (section V) ${ }^{292}$. Mitka notices Valerie’s “drawn brows” and cries, “'You're tired, Valerie.”” After her reply “ 'Yes, I believe I am a little. It's the sun”, Mitka "had a sudden vision of himself as an immense giant pulling it out of the sky and smashing it because it shone too warmly on Valerie.” On one level this “vision” is another example of Mitka’s naïve view of himself as mythical hero, but on another it glimpses his perception of control by natural forces.

The hot summer sun is a constant presence throughout the story. During the daytime scenes, references to the heat are obvious, but the sun and its effects are also suggested in the night-time drawing room by Valerie, who reflects the candle-light. ${ }^{293}$ During section VI, Valerie is twice described as "radiant". ${ }^{294}$ Mitka's perception on the same page that “ 'there’s a light shining from every little finger in you like the light

\footnotetext{
${ }^{288}$ Ibid., p. 55.

${ }^{289}$ Ibid., p. 55.

${ }^{290}$ Ibid., p. 43

${ }^{291}$ Ibid., p. 43.

${ }^{292}$ Ibid., p. 48.

${ }^{293}$ Ibid., p. 37.

${ }^{294}$ Ibid., p. 50.
} 
from a saint"” also matches this underlying vision of the sun, and that of the mythical Circe as daughter of the sun. Valerie is Mitka's god or sun, drawing him on, just as she herself is drawn and exhausted. She is both victim and victimiser. So she, although radiant and looking at Mitka "with infinite gentleness and sweetness” is exhausted: "How radiant she was, and yet there was a kind of tired languor in her gestures and her voice.”295

This harmful quality of the sun is supported by images of people being processed as food (a theme further explored in 'Prelude'). The summer heat is consistently shown as evoking body odours and perspiration, as when Mildred in section I tells the two dark young men who are boarders in her house to " 'leave your windows open",. ${ }^{296}$ A link between perspiration and being cooked is made when "the German waiter, white and sweating, handed the steaming food” ${ }^{297}$ at the midday Sunday meal. The waiter has boils in section II, ${ }^{298}$ and the term is used again when Valerie jokes in section III that “ 'I boiled in [my room] last night”, ${ }^{299}$ which suggests food processing and feeding linked to her sexual role with Evershed - perhaps one of mutual exploitation.

Finally, the references to waiters and their function of serving food suggest servility (for example, Valerie’s comment in section III that she looks “ 'like a Spanish waitress in a café chantant!’” ${ }^{300}$ ). Emotional dependence, like financial dependence, means servility and exhaustion. As shown in section VII, it is waiting that has made Mitka tired and ill:

"I have caught a fever on the top of some pleurisy [...] I believe it was anxiousness. It is so long since I have had a letter from you and the waiting and thinking from the first to hear has made me a little tired.” 301

In 'Brave Love', imagery of dirt is used to accompany that of servanthood, such as the German waiter in section I rushing up from "the dirty bowels of the house", 302 his scolding by Mildred in section II because he has boils and probably doesn’t wash, ${ }^{303}$ the "dust of hundreds of [houses]" that Valerie feels "in the hem of my skirt" 304 in

\footnotetext{
${ }^{295}$ Ibid., p. 50.

${ }^{296}$ Ibid., p. 38.

${ }^{297}$ Ibid., p. 47.

${ }^{298}$ Ibid., p. 41.

${ }^{299}$ Ibid., p. 42.

${ }^{300}$ Ibid., p. 40.

${ }^{301}$ Ibid., p. 53.

${ }^{302}$ Ibid., p. 36.

${ }^{303}$ Ibid., p. 41.

${ }^{304}$ Ibid., p. 41.
} 
section II, and the dust, dirt, and slop pail ${ }^{305}$ associated with Mitka’s room (in which he has been “waiting” for Valerie’s letter) in section VIII. The dirt imagery connecting all three characters, together with actual servanthood or association with it (such as between imagery of "waiting” and the "German waiter”) implies that all are actually or metaphorically servants. The servanthood concept is extended to most of the other characters in the story: Mildred runs a boarding-house, Paddy and Evershed earn financially to keep the allegiance of their sexual partners, and Mrs Farmer and Colonel Foster, who are too old to work, are slaves to old age.

(The concept of the "slave", as opposed to the free artist, is one that Mansfield appears to have held to throughout her life as a writer. So she wrote to Murry on 25 May 1921: “[Do you believe] that it’s only the slave (using slave in our mystical sense) who pines for freedom. The free man, the artist, seeks to bind himself.” ${ }^{306}$ A similar note is from the 1911 Murry/Mansfield manifestos: "The journalist himself cannot even dream of freedom, for he is the slave of the unreality of his own making. The artist frees himself by the realities he creates. ${ }^{\text {307 }}$ )

So in spite of their opposite natures and agendas, the two main characters are implied as vulnerable to similar forces, and at least Valerie also exercises them. Whether Mitka is exercising spiritual strength, or being driven by spiritual or other forces, in his resistance to Valerie's agenda in section VI and his floating away from her in section VIII, is left unclear. The wheel and sun images are symbols of the forces that drive the characters, and the flower, parrot, and servant images imply the characters' vulnerability (though the broken flowers also suggest Valerie's destructiveness). A further means of connecting the two characters is by parallel situations.

\footnotetext{
305 Ibid., pp. 64-65.

${ }^{306}$ KM Letters, vol. 4, p. 239.

${ }^{307}$ John Middleton Murry and Katherine Mansfield, 'The Meaning of Rhythm', Rhythm, no. 5 (summer 1912), rpt. in Hanson, p. 23.
} 


\section{Parallels in the final sections}

The parallel situations in the four final sections have the effect of unifying the ending of the story as well as encouraging the reader to explore its ambiguities - suggestions that the characters, or the forces that drive them, are in some way either similar or contrasted.

In sections VI and VIII, Valerie and Mitka are linked by each looking at their own reflection at the crucial moment in which they attain long-awaited evidence of the other's devotion. So in VI: “ 'Ah,' [Valerie] breathed - in the mirror opposite she smiled at the radiant lovely face that smiled at her, \& then she bent over Mitka [...]”308 In section VIII:

There was a piece of mirror on the wall opposite the door. As he raised his eyes he saw himself reflected in it, so transfigured, so mysteriously joyful. Mitka is dead, he thought. Mitka is a saint. ${ }^{309}$

Both these events influence those that follow them in their respective sections.

Valerie's smiling at herself in the mirror suggests her greater allegiance to herself and ironically qualifies her protestations of love for Mitka; Mitka's seeing himself as a saint, and as dead, similarly qualifies his rapture in receiving Valerie's letter (since he is paying more attention to himself than the letter) and sets the direction of his drift towards sleep and possible death, either physical or emotional. The combination of sainthood and death also suggests martyrdom, which could relate to the image of the turning wheel.

Another parallel is that through Mitka's eyes in section VI, Valerie is a saint: “ 'Ah!' he cried, 'how beautiful you are, my love - how marvellously beautiful there's a light shining from every little finger in you like the light from a saint.”,310 This vision recalls Valerie's own view of herself in the mirror and her own "Ah" as she sees it; "every little finger" suggests saintly relics. The idea of sainthood for Valerie, though qualified by her actual unscrupulousness, is still a potential strengthened by the implication, in the story's final line, that she is being turned on a wheel, martyred to her own nature.

Another form of parallel situation in the final sections is the main characters' constantly changing natures. In section VI, in which Mitka and Valerie express love for each other, both characters change from one state to another. Valerie at first has

${ }^{308}$ KM Notebooks, p. 50.

309 Ibid., p. 54.

${ }^{310}$ Ibid., p. 50. 
"a sort of delighted surprise waking in her face"311 as Mitka asserts his (short-lived) independence of her. After his emotional surrender to her, Valerie becomes "radiant”; this repeated word, and Mitka's perception of "light shining” from her, can be read as both sainthood and the radiance of the sun, relating to Circe as daughter of the sun. But this transfiguration is brief: once Mitka has "broke[n] away from her arms", ${ }^{312}$ all these cease, and Valerie sits "quite still with her head bent”. Conversely, during the course of this section, Mitka is transformed from individual asserting his independence of Valerie to dependent small boy and then to “ 'this happy man', 313 who takes over, making all the decisions for himself and her without interest in her viewpoint.

Section VIII repeats some of these changing elements: Mitka's dependence on Valerie as he awaits her letter, his own sense of transfiguration when he receives it, and then his apparent disinterest in the letter itself. In both sections it is implied that the two characters are separately in motion. This is suggested by Mildred's repeated direction to Mitka to "run along”, and his "queer run-away laugh"314 (section VI); by his insistence on leaving Valerie; ${ }^{315}$ and by his floating away in sleep ${ }^{316}$ (section VIII). The final references to Mildred, Mitka, and Valerie involve passive motion with implications of indifference: Mildred “drift[s] out of the room”317 after refusing to hear Mitka’s letter (section VII); Mitka floats away, with Valerie’s letter forgotten $^{318}$ (section VIII); and Valerie is "com[ing] round”" ${ }^{319}$ like the wheel (section IX). (This sense of motion points forward to the fluctuating viewpoints of Beryl and Linda at the end of 'Prelude'.)

Section VII also has parallels with VIII, which further interconnect the two main characters with images of sleep and dream. In VII, half-awake in bed, Valerie is given a letter from Mitka, which he has written in bed and which describes his illness and his hallucinatory dreams of Valerie. Valerie uninterestedly reads the letter, or some of it, before alternating her cynical view of the circumstances with daydreams of visiting Mitka in Marseilles.

\footnotetext{
${ }^{311}$ Ibid., p. 49.

312 Ibid., p. 51.

313 Ibid., p. 50.

${ }^{314}$ Ibid., pp. 49 and 50.

${ }^{315}$ Ibid., p. 51.

${ }^{316}$ Ibid., p. 54.

${ }^{317}$ Ibid., p. 52

${ }^{318}$ Ibid., p. 54.

${ }^{319}$ Ibid., p. 55.
} 
In the immediately following section VIII, the two characters continue to be aligned in their blurring of sleep and waking. Mitka gets out of his sickbed to receive the long-awaited letter from Valerie, delivered by the postman; his exultation and resulting sense of transfiguration blend with his view of his room and merge with memories of childhood and his life at sea; the sea image itself merges with his eventual sleep. Valerie subsequently enters, compares her daydream (from the end of section VII) with her view of the reality, removes her letter, and returns to Evershed.

This blurring of sleeping and waking could imply a similar state of mind in both characters. In section VII, as Valerie is woken by Mildred: “ 'I'm not at all awake yet,' [Valerie] said in a clear unreal voice (children who talk in their sleep speak so).” ${ }^{320}$ This implies that she may never have awakened to the real possibilities of life - a state pointing forward to Harry Kember's sleepwalking appearance in 'At the Bay’. Similarly, Mitka’s perspective in VIII is affected by his illness and exhaustion. The implication could be that both characters are in the same state of sleep and dependence and could perhaps be woken to the realities of life by each other. Within this dreaming state, both are subject to other, parallel (or the same?) forces that carry them away from each other.

In fact, the question at the end of the story is whether either character has become "free” - since this was Valerie’s concern near its beginning: “ “[T]here is only one thing. To get free and to keep free." „321 The implication, in the final line of the story, that Valerie is still turning on the wheel answers the question where she is concerned; but for Mitka, it remains unanswered. Section VIII could be read as portraying Mitka's freedom from the wheel in a renunciation of life in Buddhist or Schopenhauerian terms:

Our best hope for a lasting, though imperfect, release from the tyranny of the will is the saintly renunciation of life ... The Buddhists have got it right, or nearly right, according to Schopenhauer. The ultimate state is ... the nothingness of Nirvana. For Schopenhauer ... the closest to happiness we can come consists in the extinction of the self. ${ }^{322}$

Yet at the same time, Mitka's final vision can also be read as a childish fantasy, which will be ended by either death or his awakening to Valerie's betrayal. However, his deeply qualified vision represents a standard stratagem of Mansfield's, to recur in

\footnotetext{
${ }^{320}$ Ibid., p. 52.

${ }^{321}$ Ibid., p. 42.

322 Jeremy Stangroom and James Garvey, The Great Philosophers (London: Arcturus Publishing, 2005), p. 95.
} 
later stories in such moments as the "insect magnificat"323 of Miss Brill. Nelson Wattie, arguing for an influence of Schopenhauer on Mansfield's fiction, suggests that:

Central to Schopenhauer's thought is the perception that human suffering is inevitable ... Our bodies can, in fact, never escape [the chain of cause and effect], but our minds can do so in moments of mystic or aesthetic contemplation ... Each story of Katherine Mansfield offers the reader an opportunity to share such a moment of liberation. It is less common, however, for characters within the stories to be so privileged, although we might remember ... [for example] Bertha Young's similarly endangered moment of perception in 'Bliss'. ${ }^{324}$

With reference to Mansfield's well-known comment about “a cry against corruption” being one of her two " 'kick offs' in the writing game", ${ }^{325}$ Wattie also argues that "the corruption that causes Katherine Mansfield to cry out is the corruption of the cosmos itself”. ${ }^{326}$ So Mansfield's stance in 'Brave Love' can be read as a philosophical questioning, as in this quotation from a letter of 13 December 1919 to S.S.

Koteliansky:

And those people in England - when one goes away the memory of them is like the memory of clothes hanging in a cupboard. And yet the beauty of life - Koteliansky - the haunting beauty of "the question". ${ }^{327}$

In 'Brave Love', the "gulf to be bridged” is between the oppositions represented by the two main contrasted characters and also between the characters and setting. "Relationship" techniques that interconnect them are those of associating the two characters with contrasting yet ironically fragmented myths of predation, linking the characters by parallel situations, and associating the characters with settingderived images common to both. These techniques encourage the reader to explore and compare the characters' fragmented identities as well as the forces that drive the characters. The implication that the contrasted and fragmented characters are subject to the same kind of driving force, or to parallel forces, also supports the characters' intuitions of the double-sidedness of life. Thus the modernist aim of combining

\footnotetext{
323 "Last night I walked about [...] and lamented there was no God. But I came in and wrote Miss Brill instead, which is my insect magnificat now and always.” KM Letters, vol. 4, p. 109 (to Murry, 13 November 1920).

${ }^{324}$ Nelson Wattie, 'Katherine Mansfield as a Noble Savage: The Cry against Corruption', in The Fine Instrument, ed. Michel and Dupuis, pp. 153-154.

${ }^{325}$ KM Letters, vol. 2, p. 54 (to Murry, 3 February 1918).

${ }^{326}$ Wattie, p. 152.

${ }^{327}$ KM Letters, vol. 3, p. 161.
} 
variety with unity is achieved. Refinements of the same techniques will be used in 'Prelude'. 


\section{Chapter Two: 'Prelude'}

'Prelude' is probably one of the two most discussed works by Katherine Mansfield, the other being 'Bliss'. Interest in 'Prelude' has been ongoing, in recent times attracting sustained attention from feminist commentators. However, the density and length of this most famous of Mansfield's episodic stories allow for further interpretation through the lens of "relationships".

The background to the writing of 'Prelude' has been well documented. Vincent O’Sullivan has described how Mansfield began The Aloe in March 1915, worked on it for a month, and took it up again in February 1916 in memory of her brother, killed in October $1915 .{ }^{328}$ Alpers states that The Aloe was reshaped into 'Prelude' in response to Virginia Woolf's request, in April 1917, for a story for the newly formed Hogarth Press and was published in July 1918. ${ }^{329}$ Mansfield’s satisfaction with the quality of 'Prelude' after completing it is evident from her letter to Dorothy Brett of 11 October 1917, quoted from more fully in the introduction to this thesis.

However, three years later, writing to her husband on 27 November 1920, Mansfield used the ambiguous phrase "a child's story”, which could imply that she considered 'Prelude' to be immature: “[The form of "The Daughters”] is the form of The Prelude BUT written today - not then. The Prelude is a child’s story.”330 Similarly, in a letter to Richard Murry of 12 September 1921, she described 'At the Bay’ as “a continuation of Prelude, but better than Prelude I hope”. 331

Although The Aloe's similarities to 'Prelude' can give it the status of a previous version, the limitations of this thesis do not allow for discussing that version. This thesis will deal with 'Prelude' alone (apart from the occasional reference to The Aloe that is particularly relevant).

As mentioned above, critical commentary about 'Prelude' has been ongoing. Early approaches to Mansfield's work, through the 1930s to 1950s, tended to emphasise its romantic qualities, such as beauty, truth, mood, and purity of language. Commentary in more recent decades, starting with the New Critics and moving through

${ }^{328}$ Vincent O’Sullivan, introduction to Katherine Mansfield, The Aloe, ed. Vincent O’Sullivan (London: Virago Press, 1985), pp. vii-xii.

${ }^{329}$ Alpers, pp. 244, 282.

${ }^{330}$ KM Letters (O and S), vol. 4, p. 123.

${ }^{331}$ Ibid., p. 280. 
symbolist, psychological, feminist, literary impressionist, and post-structuralist approaches, has focused on the story's overtones of sexuality, procreation, identity, and gender politics.

The New Critics recognised Mansfield's use of "relationships”, which they used to emphasise particular themes in the story and to champion Mansfield as practitioner of different literary approaches. So Magalaner states that "the significance of 'Prelude' resides ... in its sometimes subtle, sometimes blatant patterns of association: its repetitions of images and symbols in diverse contexts". ${ }^{332}$ Magalaner follows these patterns to focus on images and themes of sexuality and pregnancy, identity, and fantasy, suggesting that the story is an "annunciation of the birth of [Mansfield's] brother". ${ }^{333}$ Magalaner also sees the "theme of identity" as part of the story's "larger motif of illusion and reality in life"; 334 thus, "particularly in 'Prelude', the real self and the false self are presented side by side" and "the fantasy world of childhood ... is shown to be the world of adults too". 335

O’Sullivan emphasises the "controlling image" of the aloe and its implications to Linda of male sexuality during the daytime and female sexuality at night. ${ }^{336}$ His "notes and approaches" also include his statement that, under the influence of Walter Pater, " $[\mathrm{t}] \mathrm{o}$ catch that flicker, to suggest the texture of that web [that is, of 'that strange, perpetual weaving and unweaving of ourselves ${ }^{337}$ ], rather than to lay down lines which are meant to define or depict life in any larger way, was what Mansfield primarily sought in her own prose”, ${ }^{338}$ In their symbolist approach, Hanson and Gurr state that "Each episode [of 'Prelude'] is played off against the next to form a complex pattern of thematic parallels and contrasts", 339 though this claim is only substantiated in detail through some examples. Hanson and Gurr concentrate on the image of the aloe, which they see as the story's main symbol with the fixed meaning of "the fundamental life-force itself”; only those characters who approach the aloe are considered able to penetrate to the deeper issues of life. ${ }^{340}$ All these commentators try to combine the recognition of associative patterning with the need to identify a central

332 Magalaner, p. 29.

333 Ibid., p. 31.

${ }^{334}$ Ibid., p. 34.

335 Ibid., p. 35.

${ }^{336}$ Vincent O’Sullivan, ‘The Magnetic Chain: Notes and Approaches to K.M.’, Landfall, vol. 29 no. 2 (June 1975), rpt. in Pilditch, p. 150.

${ }^{337}$ Walter Pater, The Renaissance, Studies in Art and Poetry (Fontana, 1961), quoted ibid., p. 139.

338 Ibid., p. 140.

${ }^{339}$ Hanson and Gurr, p. 51.

${ }^{340}$ Ibid., p. 52. 
meaning and a central character. This method can involve singling out whichever patterns support the central meaning being promoted.

Later readings have tended to support psychological, sociological, and feminist interests and assign approval and disapproval of the characters according to the commentator's viewpoint. Many of these readings have focused on the theme of identity. David Dowling suggests Beryl’s “acute schizophrenia”341 (in all three Burnell stories) caused by social pressures to play contradictory roles. Hankin sees 'Prelude' in psychoanalytic terms, concentrating on such themes as family conflict, motherdaughter relationships, sexual anxiety, and identity issues; where the last theme is concerned, Hankin interprets Beryl as portraying the "hopeless inner division" resulting from the "emotional insecurity” shown in Kezia’s childhood; ${ }^{342}$ Hankin argues that Kezia and Beryl portray aspects of Mansfield's character at different ages.

Most recent commentators on 'Prelude' have combined feminism with interests and approaches such as modernism (Fullbrook; Kaplan) and post-structuralism (Smith). Fullbrook examines the juxtapositions between the gender roles of the 'Prelude' characters and their unconscious states, arguing, for example, that Linda, victimised by Stanley, suppresses her knowledge that she hates her husband, rather than taking action to improve her situation, instead keeping the mask of her gender role in place. ${ }^{343}$ Smith also focuses on identity in 'Prelude', interpreting the story in terms of shifts in perception about gender roles. ${ }^{344}$ 'Prelude' does include much material that can justifiably be read in terms of feminist ideology, and some of these commentaries will be referred to in more detail below in discussions of particular parts of the text. However, as O’Sullivan states in a recent article arguing for a wider view of Mansfield's stories:

Since the 1970s, almost everything worth reading on Mansfield has come from ... [the] directions [of feminist and post-colonial studies]. In a broad way, ... the idea of a Mansfield story being read as a literary artefact, as an aesthetic experience, [has been] replaced by examining it as a piece of evidence, as a fragment of endorsement for a view that often existed before the reading began ... We can no longer easily imagine the reading of Mansfield not being monitored from both feminist and post-colonial watchtowers. ${ }^{345}$

\footnotetext{
${ }^{341}$ David Dowling, ‘Aunt Beryl’s Doll’s House’, Landfall, vol. 34 no. 2 (June 1980), p. 152.

${ }^{342}$ Hankin, Confessional Stories, p. 131.

${ }^{343}$ Kate Fullbrook, Katherine Mansfield (Bloomington and Indianapolis: Indiana University Press, 1986), pp. 83-84.

${ }^{344}$ Smith, KM and VW, in the chapter Shifts in 'Prelude' and To the Lighthouse.

345 O’Sullivan, 'What We Mostly Don’t Say about Katherine Mansfield’, pp. 98-99.
} 
Two exceptions to this general rule are van Gunsteren and O’Sullivan, who are interested in technique rather than ideology. Van Gunsteren argues that Mansfield's images are solely "vehicles of psychological revelation", 346 which never relate to outside meanings or truths and are therefore not symbolic (as argued by Hanson and Gurr) but impressionistic. O’Sullivan, in 1984, also argues for impressionism:

Her temperament and reading seem early to place her squarely in the tide of late Impressionism: the drift of experience that asks for vividness, the accuracy of momentary things, "that strange, perpetual weaving and unweaving of ourselves”, as her favourite Walter Pater had put it at the beginning of that tide ... She is after a style that will hold the glancing of intimations, a form that catches rather than sets. By the time she completed Prelude in 1917, she had brought her prose to the point at which some of her contemporaries were then directing poetry - to the order in what appears random, the unity possible in the apparently disparate. ${ }^{347}$

In the final half-sentence of the quotation above, O’Sullivan is hinting at the modernist approach of combining variety of experience with aesthetic unity. This "unity possible in the apparently disparate” could also involve, perhaps, a thematic content within or beyond the "accuracy of momentary things".

Both these commentators note "the sense of isolation” ${ }^{348}$ in Mansfield's work, promoting the widespread assumption that Mansfield's stories express the separate, isolated perspectives of the characters and fallible narrator without any authorial viewpoint. This type of reading is summed up in the following statement about 'Prelude':

Symbols and images are used to illuminate characters' perceptions, with any "meaning” emerging from characters' own evaluation of their inner lives, often charted through variations on the epiphany (or 'glimpse', as Mansfield called these devices). ${ }^{349}$

However, O’Sullivan's 1985 introduction to The Aloe aligns the work with expressionism as well as impressionism:

There are no ideas in The Aloe. Its "whole content", if you like, is there in precise images ... If on one side [Mansfield] is so clearly aligned with Impressionism, on the other she draws close to the Expressionists, with their interpretations of reality by the way pictorial fragments are selected and rearranged. It means that in her hands the short story could become almost pure relation rather than event; perspective as much as subject. ${ }^{350}$

${ }^{346}$ Van Gunsteren, p. 176.

${ }^{347}$ Vincent O’Sullivan, in introduction to KM Letters (O and S), vol. 1, page xiii.

${ }^{348}$ Ibid., p. xiii.

${ }^{349}$ Sarah Sandley, in The Oxford Companion to New Zealand Literature, ed. Roger Robinson and Nelson Wattie (Melbourne: Oxford University Press, 1998), p. 450.

${ }^{350} \mathrm{O}$ 'Sullivan, introduction to The Aloe, pp. xvii-xviii. 
The word "relation" above, which suggests both narration and relationship, hints at "interpretations of reality" that originate from the artist at least as much as from the subject matter or the reader. Here O’Sullivan suggests a similar combination of impressionism and expressionism as that later implied by Smith. ${ }^{351}$

The above outline suggests that two different strands of commentary have been emerging about 'Prelude'. One emphasises readings that support particular ideologies and therefore meanings that tend to be didactic. The other strand of commentary, emphasising technique, sees the importance of 'Prelude' in image, association, and arrangement, without expressing an overarching meaning or authorial ideas. However, these strands show recent signs of overlapping, with the recognition that Mansfield's work includes both impressionist and expressionist techniques; simultaneously, it may combine didactic and mimetic, satiric and lyric elements. This chapter will examine 'Prelude' with the same assumption as in chapter one: that Mansfield's approach to technique was essentially modernist, combining an awareness of diversity with the commitment to artistic unity.

'Prelude', begun (in the form of The Aloe) only weeks after the completion of 'Brave Love', takes further steps forward in the modernist direction signalled in the earlier text. 'Brave Love' is relatively conventional in its love-story plot; whereas the plot of 'Prelude' is more characteristic of modernism in consisting of "non-events". 352 Also, 'Brave Love' conventionally focuses on the two main characters in the love relationship, and the action is viewed from their varying perspectives. In 'Prelude', on the other hand, none of the five main characters clearly appears to be most important, and the action is seen through the different perspectives of them all. In both stories, however, the character viewpoints are unreliable, and 'Prelude' has been discussed as an example of literary impressionism, in which no character's viewpoint expresses a central truth. ${ }^{353}$ The story is also a departure from the conventional in that a child's viewpoint is treated as equally important to that of adults, and this viewpoint both begins and ends the story.

The lack of a conventional plot in 'Prelude' allows more direct contrast between the everyday surface and the forces underlying it, which can appear in any ${ }^{351}$ See the introduction to this thesis, pp. 9-10.

352 “ 'Non-events' are distinctive features in Modernist writing.” Michael Hollington, 'Svevo, Joyce and Modernist Time', in Modernism 1890-1930, ed. Malcolm Bradbury and James McFarlane ( The Harvester Press, 1978), p. 430.

${ }^{353}$ See Van Gunsteren (referred to on p. 70 of this thesis). 
section. Oppositions of status (master/servant, husband/wife, and adult/child) are shown as subject to those forces and can be overturned at any moment. These oppositions are also interconnected through irony.

Another way of merging the apparent oppositions in 'Prelude' is the use of central, linked symbolic processes (the growth and flowering of the aloe, and the decapitation of the duck) with which all the characters are associated. This is a development of the setting-derived images of sun and wheel in 'Brave Love': rather than being kept in the background, these main images in 'Prelude' are brought into the foreground and made central to some of the characters' concerns. These main symbolic processes, as well as parallel scenes and allusions to myth, imply mysterious forces that act on (or reflect) the characters, whatever their status. These forces are characteristic of modernism's concern with “inward states of consciousness, the nihilistic disorder behind ... the ordered surface of life" 354 or "vital energies [beneath the surface of modern life] which [are] wild, primitive and completely merciless". 355 Such forces have already been explored in 'Juliet' and 'Brave Love'. In 'Prelude' more than in the earlier stories, these forces combine positive and negative, emerging most obviously in the "one mysterious movement” that permeates section XI.

Throughout the text, ambiguous events and the characters' questioning and statements about self and existence and what is real and false are used to motivate the reader's own exploration. As with 'Brave Love', such exploration includes questioning whether freedom is possible; the reader is also prompted to discover hidden, surprising aspects of the self. Finally, myth, though far less present than in 'Juliet' or 'Brave Love', is also used in conjunction with questioning about identity.

The following discussion will examine the "relationship" methods used in 'Prelude'. Because the story has no conventional plot, its development is shown better by examining the work section by section than by discussing each type of method separately.

The title, 'Prelude', has often been speculated about. According to Alpers, it was suggested by Murry. ${ }^{356}$ From Magalaner's assertion that “the whole narrative is but prelude to the swelling act of [the baby's] coming”,357 to W.H. New's that the term

\footnotetext{
${ }^{354}$ Roy Strong, The Spirit of Britain: A Narrative History of the Arts (London: Pimlico, 2000), p. 617.

${ }^{355}$ Franz Kuna, ‘The Janus-faced Novel: Conrad, Musil, Kafka, Mann', in Modernism 1890-1930, p. 446.

${ }^{356}$ Alpers, p. 244.

${ }^{357}$ Magalaner, p. 31.
} 
"prelude" suggests preoccupation with anteriority and games, ${ }^{358}$ the title has been related to the author and her brother as individuals and to the social forces shaping "then" in comparison to the "now" of when the story was written. That "now" has to include the First World War, during three years of which the story was shaped and reshaped. At the time of the story's publication, the title 'Prelude' could justifiably have been understood as a prelude to war as well as including associations with music (such as Chopin's preludes) and poetry (such as Wordsworth's The Prelude). Whatever its implications, they are wide enough to suggest autobiographical, social, and artistic dimensions.

\section{Perceptions and questions}

In her review (June 20, 1919) of Mary Olivier: A Life by May Sinclair, Mansfield emphasised her own view that the great writers of fiction (unlike the author discussed in her review) have been explorers whose aim has been to encourage the reader to think:

Entertainment. But the great writers of the past have not been "entertainers". They have been seekers, explorers, thinkers. It has been their aim to reveal a little of the mystery of life. Can one think for one moment of the mystery of life when one is at the mercy of surface impressions? Can one think when one is not only taking part but being snatched at, pulled about, flung here and there, cuffed and kissed, and played with? ${ }^{359}$

In 'Prelude', mysterious events or moments punctuate the text: Kezia’s experience of “IT” and Linda’s of “THEM”; Linda’s and Kezia’s confrontations with the aloe and Kezia's with the killing of the duck; Beryl's and Linda's encounters with moonlight and mirrors, and the perceptions that accompany them. Although commentators have much discussed and variously explained all these events, they continue to be mysterious, provided to motivate the reader's exploration and examination of the text and to suggest possibilities rather than one definite answer.

In 'Prelude', the characters' own questions, statements, and assumptions about the nature of reality also have a similar function, like such questions and statements in 'Juliet' and 'Brave Love'. In 'Prelude', the Samuel-Josephs children's “ 'Ma! She thought it was real”360 (section I) and Kezia's questioning about "Was that really

\footnotetext{
${ }^{358}$ W.H. New, pp. $146-147$.

${ }^{359}$ Novels and Novelists, p. 42.

360 The Complete Stories of Katherine Mansfield (Auckland: Golden Press, 1974), p. 13. All quotations from 'Prelude' are from this edition, hereafter cited as KM Stories.
} 
Lottie?”361 (section II) attune the reader's awareness to the characters' perceptions of what is real and unreal. Assumptions about what is real are emphasised in Linda's thinking in section XI (for example, "How much more real this dream was than that they should go back to the house”362 ) and Beryl's concern in section XII with "her real self” and "her false self”. ${ }^{363}$ So "Was that really Lottie?” prefigures Linda's and Beryl's concerns; and the ironic structure of the text applies the children's uncertainty or assumptions about what is real and unreal to the adults.

Other childish perceptions in the text relate to getting lost and to what is surprising or different. As Lottie and Kezia travel away from the city in section III, "Everything looked different" and in time "they were quite lost". ${ }^{364}$ The sense of getting lost in unfamiliar territory and being surprised are repeated in Lottie's and Kezia's excursions into the garden ${ }^{365}$ (section V and section VI), where Kezia’s plans to surprise her grandmother are overshadowed by her amazement at the aloe; ${ }^{366} \mathrm{a}$ similar train of events is the children's excursion into the paddocks with Pat, where they encounter the duck's decapitation (section IX). The concept of surprise is explicitly related to the adults via Beryl's oil painting in section XI:

Above [the piano] hung an oil painting by Beryl of a large cluster of surprisedlooking clematis. Each flower was the size of a small saucer, with a centre like an astonished eye fringed in black. ${ }^{367}$

Particularly the concepts of unfamiliarity and surprise are repeated in the use of imagery in the story; and the text itself becomes a vehicle of surprise for the reader, who repeatedly finds the familiar becoming strange as it is linked to the unexpected and transformed through play.

The following part of chapter two explores how, in the first seven sections of 'Prelude', “relationships” are used to surprise readers and characters by setting up and undermining expectations about power and status.

\footnotetext{
${ }^{361}$ Ibid., p. 14.

${ }^{362}$ Ibid., p. 53

${ }^{363}$ Ibid., pp. 57 and 59.

${ }^{364}$ Ibid., p. 16.

${ }^{365}$ Ibid., pp. 26 and 32.

${ }^{366}$ Ibid., pp. 33-34.

${ }^{367}$ Ibid., p. 52.
} 


\section{Sections I to VII: Subversions of status}

As suggested in the section above, there is an ironic structure in 'Prelude': status oppositions of adult/child, master/servant, and husband/wife are subject to forces that can overturn them, which involves the ironic interconnections of these opposites in the text.

As outlined in the introduction to this chapter above, recent commentators have tended to see Stanley as upholding the patriarchal system of control, which the women of his family either resist or succumb to in their various ways. For example, Heather Murray reads Mrs Fairfield as supporting the status quo ("She has survived by not thinking, by burying self, by carrying out the mundane chores of life" ${ }^{368}$ ); she reads Linda as having “a streak of cynical nihilism”369 in her view of her future and sees Mansfield’s treatment of women as one of "profound pessimism” since “[in Mansfield's view?] [f]emale freedom is an illusion”. 370

Certainly, on one level, 'Prelude’ does attack the patriarchal system. There are plenty of examples of Stanley’s arrogantly superior attitude, such as the way, in section III, he eats and flirts with Beryl while commanding his tired mother-in-law to run errands; ${ }^{371}$ or his assumptions in section VII that he will organise his family's weekend activities around himself. ${ }^{372}$ Stanley differs from all the other characters in the story in that he controls them financially; but all the other characters also express forms of control and superiority over others, and Stanley himself is shown as vulnerable as the story progresses. In fact, section I of 'Prelude' sets up oppositional pairs that have no direct reference to Stanley at all. These oppositions are typical of the story throughout, but nowhere else in the text than in section I is their contrast so marked, since this section is used to set up expectations that are later undermined.

\footnotetext{
${ }^{368}$ Heather Murray, 'Linda Burnell, Housewife: A Life Sentence for Cowardice?', Women’s Studies Journal, vol. 4 no 2 (1988), p. 36.

${ }^{369}$ Ibid., p. 36.

${ }^{370}$ Ibid., p. 38.

${ }^{371}$ KM Stories, p. 20.

372 Ibid., p. 36.
} 
Section I sets up oppositions between children and adults, the vulnerable and the (apparently) powerful, the individual and the group. It conveys Lottie’s and Kezia's vulnerability to their mother's and neighbours' mockery and laughter. The contrasts between high and low, powerful and vulnerable, laughter and weeping, separate the characters into two groups: Lottie and Kezia opposed to all the rest. The younger children's low stature and vantage point, the fact that there are two of them, their “round solemn eyes”373 (echoed later in the ducks' “round eyes" ${ }^{374}$ ), and their "little round caps with battleship ribbons” (linking with "the little Irish navy”375) anticipate the two ducks grabbed by Pat in section IX. Linda Burnell, on the other hand, in her situation of power as she laughs at her children with eyes closed, seems to anticipate the aloe's cruelty, height, and "blind stem”376 (section VI). Already at this early stage, association with the two central symbols, the aloe and the duck, strengthens oppositions of power and vulnerability.

Other imagery acts as a counterstatement to the separation of these groups. For example, $\mathrm{New}^{377}$ has pointed out images of restriction used throughout the story: the "holdalls, bags, and boxes" that surround Linda and the "buttoned leather cushions" that she leans against can be read as suggesting her sense of confinement. Mrs Samuel Josephs (like the two younger children) is also described in imagery relating to the duck, since she "waddle[s]”. This imagery is part of her grotesqueness as part animal, part object - a human distorted by childbearing. Her obvious enjoyment of the role in spite of its distorting qualities is as disturbing to reader and children alike as Linda's alienation from that role. These implications of restriction already signal a concern similar to that in 'Brave Love': the questioning of whether freedom is possible.

The second part of section I reiterates and strengthens the sense of the children's helplessness set up in the first, though now it is Kezia who seems most vulnerable to the wider group. Made to sit apart from Lottie, who has "swelled" with self-importance at her "success" in the eyes of the Samuel Josephs, Kezia is tricked and then laughed at by the whole group - derision that recalls her mother's.

The section ends with Kezia's tear and her construct of “a dear little sort of a gate” - an image of escape from her entrapped situation. Kezia's transformation of her bread and dripping into an image of freedom by standing it up recalls her mother's

${ }^{373}$ In this chapter, references to the section of 'Prelude' under discussion will not be footnoted.

${ }^{374}$ Ibid., p. 44.

${ }^{375}$ Ibid., p. 45.

${ }^{376}$ Ibid., p. 34.

${ }^{377}$ New, pp. 154-157. 
fantasy of turning her children upside-down. This concept of turning or being turned upside-down, either in fantasy or fact, is a repeated motif in the story. Though in this section at opposite ends of the power spectrum, Linda, the Samuel Josephs, and Kezia experience play that, in fantasy, overturns their circumstances. Kezia's response to the deception, betrayal, and surprise involved in this play process is frail and pathetic yet makes use of the same forces that afflict her. So even at this early stage of the story, the apparently powerful and the vulnerable are making use of the same forces.

Another point of interest here is the probability that the Samuel Josephs are Jewish - a subject generally avoided by commentators since it suggests anti-Semitism on the part of the author. However, the apparent satire based on this family group later rebounds on the Burnells, since Stanley Burnell exhibits similar dominating traits to Stanley Samuel Josephs. Also, the name of Moses in this context of departure to another home recalls the exodus of the Jews, a myth of liberation. This "bounding outline" hints at the ideal of freedom. ${ }^{378}$

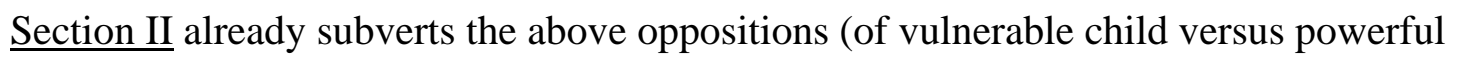
adults or group) in two different ways. One is to suggest Kezia's developing creative identity and thus sense of control; another is to qualify her naïve viewpoint with her intuition of wider realities - an approach balanced in later sections when adults' behaviour and perceptions are ironically likened to those of children.

Alone in "their own house", Kezia has control, and she can take or leave whatever she chooses, although her wandering alone through the deserted house has an element of pathos suggested by the verbs “wandered” and "trailed”. New, in arguing that the text demonstrates how the past limits the future, has discussed section II in terms of its "remnants of the past that [Kezia] finds to take with her as mementoes ... some beads, a needle, a pillbox, and a stay-button”. ${ }^{379}$ Although they can be read as images of restriction and containment, as New asserts, these objects are associated at least as much with the characters who owned them as with Kezia; and it is only the pillbox ("black and shiny outside and red in, holding a blob of cotton wool”) that Kezia is explicitly shown as deciding to keep. Its colours and the white "blob" the pillbox holds suggest a womb and foetus, implications strengthened by Kezia's thought of keeping a bird’s egg inside it.

${ }^{378}$ In 'Prelude', allusion to myths and other works is probably more localised than the allusive parallels in the works explored in chapter one.

${ }^{379}$ New, p. 155. 
Kezia's responses to the three different sets of windows she sees in the empty house give an impression of her isolated development within her family - a development that also has an element of pathos. Her window games merge confinement and escape. Though frames imply constraint, ${ }^{380}$ the first two windows combine a sense of what covers the glass with what lies beyond it. The first window, partly obscured by a Venetian blind, also suggests distance by the implied late afternoon sun throwing shadows through it onto the floor; the bluebottle image reinstates a sense of entrapment. Kezia's look through the coloured glass in the diningroom window suggests the freedom to see the world through different perspectives as well as questioning what is real. The mention of "a little Chinese Lottie" can be read as "a dismissal of things 'Chinese"” that "illustrate[s] the ethnic boundaries of the time” ${ }^{381}$ or a fascination with the distant and exotic that is characteristic of Linda's interest in the Orient (as expressed in section V). ${ }^{382}$

Kezia’s pressing her hands against the pane of the third window, watching "the funny white tops that came on her fingers”, reinforces the sense of constraint and suggests that she is no longer aware of what is beyond the glass. At this point, Kezia is surprised by nightfall and its associated fears: her ebbing sense of control is transformed to a situation of panic-driven movement, an instantaneous change of status. The childish fantasy of "IT" is on one level a direct confrontation with the forces that determine existence: Kezia's experience has overtones of both birth and death.

On one hand, "IT" recalls the use of the same pronoun to mean death in the Garnett translation of War and Peace. The passage describing the death of Prince Andrey is similar to the Mansfield passage in that in both texts, the pronoun "it" is used to suggest a terrifying force about to emerge from behind doors. For example:

Once more It was pressing on the door from without. [Prince Andrey's] last, supernatural efforts are vain, and both leaves of the door are noiselessly opened. It comes in, and it is death. ${ }^{383}$

On the other hand, Kezia's forced exit downstairs and out from the house of her early development can also suggest birth, implied by association with the pillbox/bird's

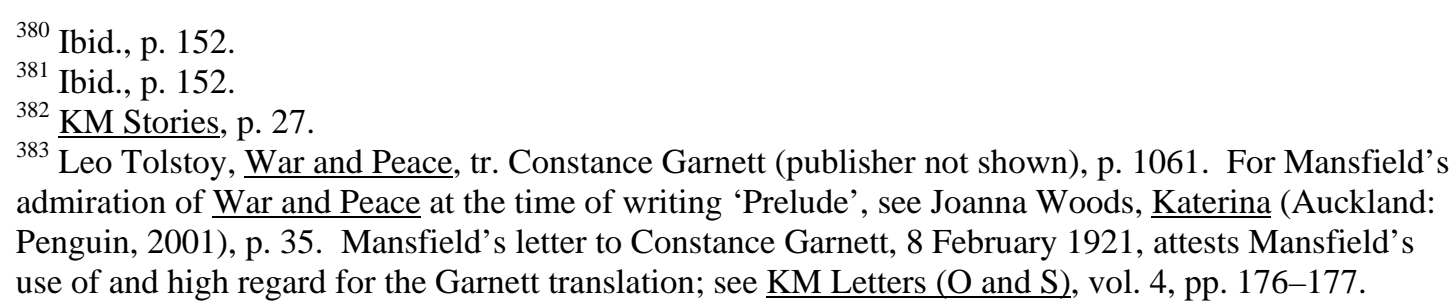


egg combination and by the womblike overtones of the constricting house, an environment that now belongs to Kezia's past. The end of the section, in which the children are wrapped in a shawl and blanket to set out into the unknown, continues the suggestion of birth.

In the first half of section III, the two children, and especially Kezia, are shown in a position of power and freedom, suggested by their height, movement, and ability to see for vast distances, which contrast with the constraint and immobility of the previous sections. Particularly Kezia is in a situation of power, since she knows the storeman as an "old friend". Her memory of buying grapes from the storeman with her grandmother supports her sense of safety. At the same time, the grapevine imagery has wider overtones qualifying Kezia’s experience of the "one beautiful vine” with implications of wider natural processes that she does not yet understand. For example, the storeman's "horn knife” that he had "in his belt” anticipates Pat's tomahawk "stuck [...] in his belt”, with which he will kill the duck ${ }^{384}$ (section IX); the horn knife also anticipates the storeman's explanation that a ram is different from a sheep because it “ 'has horns and runs for you'”. The qualification of Kezia’s sense of freedom is further strengthened by her naïve questions and statements about "rushing animals", which merge with her remembered dreams of animals with swelling heads (and her fears of “IT") and anticipate Linda's lifelong fear of "things that rush at her" 385 (section XI). Feminist commentators have tended to focus on the potential "sexual terrors” implied by Kezia's questions and by her relationship with the storeman. So Smith singles out only one of Kezia's questions to the storeman:

... for Kezia it is a voyage of discovery as she leaves behind the familiar town and goes into territory that for her is unmapped ... The question she puts to the storeman in the darkness is: " "What is the difference between a ram and a sheep?"” (p. 17). His rather evasive response, that a ram has horns and runs at you, and her dislike of the prospect, anticipate her mother's sexual terrors, and Kezia strokes the storeman's sleeve, "it felt hairy” (p. 17), as Linda later strokes the wallpaper and feels the poppy on it "hairy like a gooseberry skin" (p. 27). ${ }^{386}$

However, one of Kezia’s other questions, about whether "stars ever blow about”, suggests the mythical quality of the journey for her; this quality is also conveyed through the journey's imagery of moonlight, starlight, and harbour lights with which the passage opens; through the fact that the storeman "towered beside her big as a ${ }^{384}$ KM Stories, pp. 44 and 46.

385 Ibid., p. 54.

${ }^{386}$ Smith, KM and VW, p. 107. 
giant”; through the background image of the "one beautiful vine” that (suggesting a cathedral) "span[s] and arche[s] over” the storeman's glasshouse; and through her first view of the new house, with its "pillared veranda and balcony all the way round", which "lay stretched upon the green garden like a sleeping beast". In fact, the storeman himself can be read as a Dionysian figure through his association with the grapevine and through the fact that Lottie after dismounting from the wagon is described as "drunken”. So in this half-section, intimations of the mythical and the terrifying qualify each other, merging in the implication of Dionysus, which combines both. Kezia's wakefulness and questioning for much of the journey (contrasted with the sleeping Lottie, she "could not open her eyes wide enough”) emphasise her creative, perceptive identity.

In the second part of section III, the fact that Kezia is allowed to carry the lamp into the house implies that she continues her perceiving role; Hanson and Gurr read the light as "spiritual light” in contrast to "material goods", ${ }^{387}$ and Dowling sees it as revolutionary, a "beam of light revealing the persistent, tragic operations of society". 388 However, this half-section initially reinstates the oppositions of vulnerable child and powerful adult that were set up in section I. Once Kezia enters the house, an oppressive aspect is implied as the "hundreds of parrots [...] on the wall-paper ... persisted in flying past Kezia with her lamp" (linking to her fear of "rushing animals like dogs and parrots” earlier in the section). The sense of oppression is confirmed as the adults in the house, in contrast to the storeman's tenderness with Lottie and Kezia, pay scant attention to them and as the contrasting levels of husband/wife, master/servant, and adult/child become apparent through the conversation. Even Mrs Fairfield seems more concerned with "[p]oor little mother" than with the two most recent arrivals, as if Linda is also a child but still takes precedence.

Gradually, though, this conventional hierarchy is undermined, since the characters' varying responses show that only some uphold it. For example, Beryl plays up to Stanley at first but then, from her lower, near-servanthood level, challenges his authority with an implied "rebuke” and laughter (recalling the derisive laughter in section I). Stanley's alteration in his sense of status, continued as "the chops began to fight the tea in his sensitive stomach", is completed as Linda "drag[s] him down to the

\footnotetext{
${ }^{387}$ Hanson and Gurr, p. 51.

${ }^{388}$ Dowling, p. 157.
} 
side of her long chair”. Also, Kezia pushes the boundaries between adult and child by “drinking tea out of Aunt Beryl's cup”. The status quo implied in section I is shown as unstable, varying from moment to moment.

Different image strands running through this section give a sense of opposing dimensions. One is the barnyard imagery that associates characters with animals: so Beryl has a "long pigtail" and says that her mother has "worked like a horse"; and Stanley "scented a rebuke”, "chaffed”, and "began picking his strong white teeth". This animal imagery links the characters to the "rushing animals" that Kezia mentioned earlier in the section; yet these images can also suggest the exploitation and restriction of domestic animals. Another strand of imagery, depicting water and light, conveys the sense of unfamiliarity and excitement at the new house: so "A strange beautiful excitement seemed to stream from the house in quivering ripples" and "Outside the pool of lamp and firelight the room stretched dark and bare to the hollow windows." The lyrical combination of water and light also conveys a sense of transience, anticipating the actual stream that, later in the text, becomes a site of danger. These images connect the characters' perceptions with the setting, suggesting the same forces active in all.

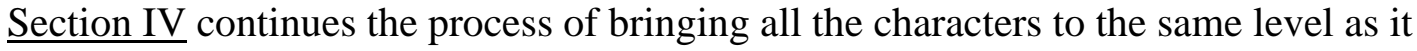
depicts the bedtime rituals of each and their vulnerability to night-time fears, desires, and dreams. The section as a whole is framed by the preparations for sleep of Kezia and her grandmother, connecting youth and age. The section is ended by the comments and laughter of the night birds at the whole family: "more pork" relates to the satirical livestock imagery. Fullbrook has commented:

The voices of nature perfectly mimic the unconscious situation of the Burnells. The varieties of conventional and unconventional ritual performed by the entire group before they sleep is subsumed by the antipodean "more pork" of the wise little owls, echoing Stanley's feat of digestion earlier in the evening, and the general impulse to devour one another prevalent in the family as a whole. ${ }^{389}$

Less cannibalistically, the birds' comments and laughter suggest that the characters are victims of a cosmic joke, since the text will go on to suggest that they are devoured by society and nature as much as by each other.

The section moves, in general, from the youngest members of the household to the eldest, comparing and contrasting the family members' illusions and/or pretensions. ${ }^{389}$ Fullbrook, Katherine Mansfield, p. 72. 
For example, Lottie’s and Kezia's ideals of a strong, protective sexual or religious figure (Kezia’s “Indian brave” and Lottie’s “simple Lizzie”) combine with mix-ups about gender; Beryl's ideal of a lover or husband merges with thoughts of sexuality and financial wealth, as does Linda's actual experience with Stanley in the following passage; and the grandmother's sighs at Kezia’s “ 'I'm waiting for you”” could result from her memory of her husband, who may have said the same thing at bedtime to her. Most of the passages link sexuality with vulnerability to the head and neck: Kezia kisses her grandmother under the chin; Beryl attracts an imaginary lover who "thrusts his head among the bright waxy flowers” he holds; and Stanley draws Linda to him by slipping "his arm under her neck". All these anticipate the key image of the duck's decapitation, which will be used to imply processing by society and biology.

The most striking imagery in the section is given to Beryl, whose acting, fantasising, and self-display in the moonlight are permeated by lyrical images of nature: a pool of moonlight, "two fanning wings", the flowers of the garden, and eaude-nil satin, the first and last of which point towards the stream from which the ducks are taken. Another strand of natural imagery is that of curling, anticipating the grapevine’s “tiny corkscrew tendrils”390 in section VI and suggesting natural development: so Kezia “curled in her grandmother’s soft bed” and "rolled herself into a round”; Lottie and Isabel "lay down back to back, their little behinds just touching”; and Linda asks Stanley to “clasp” her.

An accompanying set of images is that of the characters' assumptions about colonial exploitation: Beryl’s about “Government house” and "the new governor”; Stanley's and Linda's about their rights to acquire land and accrue wealth from it; and Kezia’s about American Indians, dispossessed by the colonial process in decades not long before the time in which 'Prelude' is set. The comments of the birds suggest that all the characters are "more pork" - commodities in the same biological, financial, and social mechanism.

${ }^{390}$ KM Stories, p. 28. 
$\underline{\text { Section V }}$ continues to subvert the implication in section I that it is only adults who have power, and only children who are hurt and betrayed by it. Linda's early-morning dream combines her childhood with her maturity, depicting her as a child (wearing an apron) walking with her father, who laughs at her as the bird she innocently picks up becomes a baby too huge to hold. Her father's “loud, clattering laugh” merges both with the sound of the birds outside (especially recalling the "harsh rapid chatter: 'Haha-ha ... Ha-ha-ha," 391 of a night bird the evening before - section IV) and with the noise of the blind that Stanley inconsiderately wakes her with by rattling it "up to the very top”. So the laughter that Kezia was exposed to in section I is recalled here, suggesting Linda's sense of betrayal by her father, her husband, and the biological forces that compel her to bear children. Linda as child and adult are combined. Even Stanley and their children are combined in the dream image of the huge bird-baby with its “round eyes”, which recall her children's ${ }^{392}$ in section I and anticipate Stanley’s "blue eyes fixed and round in the glass” later in section V.

The weird, sudden transformation in Linda's dream, in which idyll becomes nightmare, is recalled in her waking experience later in the section, in which the familiar becomes strange: items of “the old paraphernalia” from her and Stanley’s previous bedroom begin to “come alive”, suggesting a different, unknown dimension. At that point, another telescoping of adult and child occurs as Linda's irrational fear of “THEM” recalls Kezia's fear of “IT” in section II - a "relationship” that has often been commented on to suggest the similarity of the two characters, which is unknown to both. "THEY", of course, with their mysterious swelling, have often been read as reflecting Linda's fear of childbirth as depicted in her dream. However, Linda's feelings change into their opposite: her fear becomes fascination:

Only she seemed to be listening with her wide open watchful eyes, waiting for someone to come who just did not come, watching for something to happen that just did not happen.

Yet the imagery of "the silence spinning its soft endless web", the fact that "she hardly had to breathe at all”, and Linda's sense of floating suggest that what she is waiting for parallels what happens to the ducks, which is death. The implication of the passage is that, as the objects around her "come alive", she becomes an object, somehow crossing a boundary into their world. So the tendency of this section is to act as a counterstatement to section I, in which Linda appeared so powerful: here she is ${ }^{391}$ Ibid., p. 24.

${ }^{392}$ Ibid., p. 11. 
equivalent to both child and object. The situation of section I (in which she imagined her children as objects) ${ }^{393}$ is reversed, and Linda is vulnerable to her children. Also, Linda's total self-abnegation to "THEM" in this passage ("if she gave herself up and was quiet, more than quiet, silent, motionless”) can be ironically linked with the "beautifully basted resignation" 394 with which the cooked duck lay on the plate (section XI).

Simultaneously, the words "waiting for someone to come who just did not come, watching for something to happen that just did not happen” also describe Beryl's situation of waiting for a suitor, so this passage's implications of vulnerability and of equivalence to both child and object apply to Beryl too. In the case of both Linda and Beryl, these implications of “waiting” recall that, in 'Brave Love', the same word was associated with servanthood; which itself recalls Mansfield's and Murry's distinction between slave and free in their 1912 manifestos, and Mansfield's statement to Brett in 1920 that "the only free people" 395 are artists.

Yet the final part of section V is ambiguous, since Linda's response to THEM may recognise a dimension that is in the last resort mysterious and may not be societal or deathly; the ambiguity helps to leave Linda's identity as a mystery too, since the reader remains uncertain what this self of Linda's is responding to. Reading her passivity at the end of this section as attraction and vulnerability to such a mysterious force is supported by a letter to Mansfield's husband, on 18 October 1920, which describes her own sense of the meaning of the silence (in the context of physical suffering) in terms very similar to Linda's in 'Prelude':

... I have felt very often lately as though the silence had some meaning beyond these signs these intimations. Isn't it possible that if one yielded there is a whole world into which one is received? It is so near and yet I am conscious that I hold myself back from giving myself up to it. What is this something mysterious that waits - that beckons? ${ }^{396}$

\footnotetext{
393 Ibid., p. 12.

${ }^{394}$ Ibid., p. 50.

${ }^{395}$ KM Letters (O and S), vol. 3, p. 262 (to Brett, 26 March 1920).

396 Ibid., vol. 4, p. 75.
} 
Section VI is permeated by imagery of plant growth, beginning with the image of the grapevine and ending with that of the aloe. Within this framework, the development of the family is shown, moving from the past (Mrs Fairfield's memories) to the future (the ambiguous significance of the aloe's future flowering). This plant imagery contrasts with, and yet parallels, the forces of fantasy suggested in the previous section. In the first half of section VI, the transforming process of the grapevine is associated with Linda, Beryl, and Mrs Fairfield in their development through time as well as in the force of their individual perspectives.

The "knotted vine" that "grew" over the lean-to is presented as a transforming force, "com[ing] right through some cracks in the scullery ceiling” and giving the windows of the lean-to "a thick frill of ruffled green"; the words "grew" and "ruffled" also directly echo the description of the bird-baby in Linda's dream ("it ruffled and pouched, it grew bigger and bigger»397). So the forces of fantasy parallel, or are merged with, those of nature. Mrs Fairfield's memory of Beryl as a child also links the grapevine to Linda's dream, because Beryl's childhood experience of picking grapes turns to nightmare, with resultant swelling (as in Linda's dream) and screaming. In both cases the innocent childhood action of harvesting something leads to becoming harvested.

This repeated combination of child and adult in Beryl's experience is supported by the details of Mrs Fairfield’s appearance: her white cap, white apron, "arms [...] bare to the elbow and stained a bright pink", and action of fetching more hot water suggest a midwife. (In The Aloe Mrs Fairfield does act as midwife to Linda when Kezia is born. ${ }^{398}$ ) Associated with Mrs Fairfield's midwife implications, Beryl’s remembered swelling and screaming also ironically anticipate her future in her desired role of wife. Like Linda's dream, this view of Beryl merges childhood development with the procreative role.

The character of Mrs Fairfield has been much debated, with some commentators disparaging her for supporting the patriarchal status quo and others praising her attunement to nature and creativity. In fact, the imagery suggests both: for example, her cap’s similarity to a “jelly mould” anticipates the cooked duck’s being compared to a jelly ${ }^{399}$ (section XI); and her organising everything into "a series of patterns” is similar to Mansfield's own “relationship” techniques in her texts. In fact, ${ }^{397}$ KM Stories, p. 24.

${ }^{398}$ The Aloe, ed. O'Sullivan, p. 9.

399 KM Stories, p. 50. 
Mrs Fairfield's creativity within the limitations of her servant role can be seen as reflecting Mansfield's idea of the true artist, who is "free”, whereas "it's only the slave (using slave in our mystical sense) who pines for freedom”. ${ }^{400}$ Mrs Fairfield's concern for art is also demonstrated by her care, later in the section, for the two Chinese pictures, a response that contrasts with Beryl's disparagement of them and suggests reverence for other art created in circumstances of constraint.

Beryl's advent into the kitchen demonstrates a response to constraint that contrasts with her mother's acceptance of it. Beryl in this half-section is full of spite, anger, and impatience, implied by her hammer, nails, biting her lip, and "digging the stiff brass safety-pins into the red serge curtains". The sharpness of these items and her rapid, impatient movements, including "rush[ing] in", suggest that she is a "rushing animal” driven by forces beyond her control; and the fact that she wants to bury Stanley's tokens of self-display in or near the kitchen seems a response to his wanting to bury her so “very far away from everything”. Beryl’s disparaging attitude to her mother as she looks down on her, "loftily”, from above suggests her own sense of higher status; which is already qualified in advance, as it were, by Beryl's actual similarities in status to Alice, the servant girl. So Beryl, "very flushed, dragging with her two big pictures”, anticipates Alice in section VII, who with her "crimson face" "lunged in with a heavy black iron tray". ${ }^{401}$ Yet Beryl's song later in the section (“How many thousand birds I see / that sing aloud from every tree”) suggests an ideal of freedom; its bird and tree imagery anticipates Linda's moment of freedom at the end of section XI: "Beautiful were the rich dark leaves spangled with light and the round flowers that perch among them like red and white birds." 402

The entrance of Linda, the mistress of the house, further qualifies Beryl's sense of status; and Linda’s waving a knife at Beryl as she asks “ ‘ Beryl, do you want half my gingerbread?'” hints at a mutual antagonism possibly fuelled by half-conscious jealousy about status and Stanley. Linda’s eating gingerbread links to Stanley’s "bushy ginger hair”, ${ }^{403}$ mentioned in the previous section. So Linda's own status is quietly subverted by implications of her appetite for something that Stanley offers her, whether physical or financial. (Linda's liking for gingerbread is further hinted at in section VIII,

\footnotetext{
${ }^{400}$ KM Letters (O and S), vol. 4, p. 239 (to Murry, 25 May 1921).

401 KM Stories, p. 39.

402 Ibid., p. 55.

${ }^{403}$ Ibid., p. 25.
} 
when Pip and Rags bring "a batch of our gingerbread for Aunt Linda” ${ }^{404}$ ) So this liking for gingerbread suggests a hidden aspect to Linda; just as the previous section has also described Linda's hidden fantasy life, which is also unknown to the other members of her family. Both of these suggest her own responses to constraint, another of which is the comfort she derives from her mother.

In this half-section, the three women are depicted in ways that qualify each other and suggest different aspects of themselves. However, all three are linked, some more and some less directly, to the framing image of the grapevine, which (similarly to the one in section $\mathrm{III}^{405}$ ) suggests a single, enveloping process. Like the more developed image of the aloe in the next section, the grapevine frame ironically qualifies the characters' varying sense of status and links them to the setting and to the cyclic (and also mythic, Dionysian ${ }^{406}$ ) world of natural processes. The imagery of this half-section is also part of the lead-up to the first appearance of the aloe.

The second half of section VI explores implications of Kezia's developing creative freedom by juxtaposing and connecting them with the constraints of the women in the house in the first half of the section and with the aloe at the end. As in the vignette 'In the Botanical Gardens', this garden is separated into a dark, primitive side and a brightly flowered artificial side, which it reconnects by Kezia’s exploration of both, by the fact that each is described as "a tangle", and by the flowers full of insects found in both. In fact, each side has hints of danger, since the multitude of roses in the flowering side must have thorns, recalling the sharp implements associated with Beryl and Linda in the previous half-section. Although Kezia's exploration of the two sides suggests a sense of freedom that contrasts with the confinement of the adults in the house, her experience also suggests the adults' constraints. As New has noted, the dusty "box borders” recall the dusty frames of Stanley’s pictures; ${ }^{407}$ similarly, "Kezia bent down to look and sneezed and rubbed her nose” echoes Beryl's “ 'I’ve been poking into that cupboard under the stairs and now something keeps tickling my nose." "New reads this half-section to suggest that "the boxing of the future already limits it". 408

\footnotetext{
${ }^{404}$ Ibid., p. 42.

${ }^{405}$ Ibid., p. 16.

${ }^{406}$ See p. 80 of this discussion.

${ }^{407}$ New, p. 155.

${ }^{408}$ Ibid., p. 155.
} 
However, the description of the garden's two sides is framed by mention of the orchard, through which Kezia passes to get to and from the garden. The two similar yet opposing ideas of her being " 'tossed by a bull'” and rolling "over and over into the thick flowery orchard grass” portray her as subject to forces of desired or undesired change (similar to the wheel imagery in 'Juliet' and 'Brave Love'). In Kezia's case, these forces lead to creativity as a natural result, like fruit falling in the orchard into which Kezia rolls. Kezia's wanting to surprise her grandmother aligns her creative impulse with other surprises, pleasant or unpleasant, that nature prepares, such as the red ant surprising Beryl in the first half of the section. Kezia wishes to select from and combine the flowers in unexpected patterns, like those her grandmother makes, and in this way Mrs Fairfield is a midwife to Kezia’s creativity. Kezia is still planning these surprises as she is "scrambling up the grass on her slippery shoes" - a phrase that anticipates the ducks" "flapping and scrambling up the bank" 409 towards the decapitation event in section IX. Kezia’s creative identity can later be read as both confirmed (by the aloe's flowering) and annulled (by its impersonal, towering cruelty and ugliness as an all-inclusive symbol of life itself).

Kezia's natural impulse to astonish is ironically counteracted by her own surprise at encountering the aloe:

Whatever could it be? She had never seen anything like it before. She stood and stared. And then she saw her mother coming down the path. "Mother, what is it?" asked Kezia.

Kezia's questions about what the aloe is and whether it flowers, and Linda's answers to them, parallel the reader's questions and answers, since the meaning of this symbol has been much debated. Commentators have recognised that this encounter with the aloe is at the centre of the story and the only point at which Linda and Kezia communicate. They generally see its meanings as relating to the generational (through Kezia's eyes) and the procreative (through Linda's). The future flowering has been interpreted as, for example, that of sexuality, ${ }^{410}$ of procreativity, ${ }^{411}$ or as a promise of life itself flowering for Kezia ${ }^{412}$ or for Linda. ${ }^{413}$

The aloe is a symbol that combines oppositions and so can be seen as representing life itself; it is also an expanding symbol, taking on further meaning as the ${ }^{409}$ KM Stories, p. 45.

${ }^{410}$ Summarised in Andrew Gurr, 'Katherine Mansfield: The Question of Perspectives in Commonwealth Literature', Kunapipi, vol. 6 no. 2 (1984), rpt. in Pilditch, pp. 204-205.

${ }^{411}$ Magalaner, p. 30.

${ }^{412}$ Gurr, p. 205.

${ }^{413}$ Murray, 'Linda Burnell, Housewife’, p. 34. 
story progresses. As commentators have noted, it stands between the two sides of the garden. The aloe recalls aspects of both sides: Linda's idea that the aloe "might have had claws instead of roots" recalls the "tree roots ... like the marks of big fowls' feet"; the old leaves of the aloe, "split and broken" or lying "flat and withered on the ground" recall the fallen rose petals; the "cruel leaves" link to the likely thorns of the roses; and the possible flowering relates to the flowers on both sides of the garden.

At the same time, the aloe's similarity to the people in the house and garden of section VI links the section's two halves. Its “thorny leaves” recall Beryl’s spitefulness; its towering height parallels Linda's, Beryl's, ${ }^{414}$ and Stanley's si5 sense of status, seen here in Linda's "smil[ing] down at" Kezia; its "blind stem” is seen in Linda's "half shut[ting] her eyes"; and the older leaves that "turned back" recall earlier generations, represented by Mrs Fairfield. The fact that the aloe "seemed to be hiding something” is similar to the characters in Linda's turning her head away from the mirror $^{416}$ (section V) and in Beryl’s acting a carefree part to her sister in section VI but dropping that part when reaching another room; the aloe's "hiding something" can also suggest the concealment of pregnancy and anticipates the theme of the buried self. And as commentators have tended to agree, the “fleshy stem” suggests Stanley's sexuality. ${ }^{417}$ So the aloe links to the past, the present, and the future, in which its flowering is located; and this future flowering could align both with Linda's childbearing (especially of the hoped-for son) and with Kezia’s flowering as artist, as suggested in her creative impulses. A further future characteristic of the aloe is that, if it is an agave (as discussed on pages 90-91 below), it will die after flowering - which has implications for both Linda and Kezia.

The aloe's appearance in the centre of the story also links the story's first and second half, pointing forward to further meanings later in the text. The characters' sense of their different levels of status is ironically counteracted by the fact that all of them are likened to this same symbol. In general, like other combinations of birth, sexuality, and death in the story, the aloe symbolises a process in which all three are represented. (The other processes or symbols associated with birth, sexuality, and death are the grapevine image in sections III and VI and the death of the duck in section IX.)

\footnotetext{
${ }^{414}$ As in "she supposed, loftily": KM Stories, p. 30.

${ }^{415}$ As expressed in section III, ibid., p. 20.

${ }^{416}$ KM Stories, p. 28.

${ }_{417}$ Gurr, pp. 204-205.
} 
The aloe also has mythical connotations. Commentators have pointed out the aloe's resemblance to the tree of knowledge; for example, Gurr agrees that the aloe is "a phallic tree of knowledge". ${ }^{418}$ Its location in the middle of the garden (between its two halves and in the middle of the drive) does recall the "tree of the knowledge of good and evil", "which is in the midst of the garden". 419 Of this tree, God says, "Ye shall not eat of it, neither shall ye touch it, lest ye die"; whereas the serpent says, "For God doth know that in the day ye eat thereof, then your eyes shall be opened, and ye shall be as gods, knowing good and evil”. ${ }^{420}$ The concept of eyes being opened links to the motif of wide-open eyes used in 'Prelude', especially the association of flowers with surprised eyes, as in Beryl's oil painting of “a large cluster of surprised-looking clematis" (section XI). ${ }^{421}$

A further myth-related implication of the aloe could be located behind its name and imply a further aspect of Linda. Linda's answers to her daughter's questions - that the plant is an aloe and flowers once every hundred years - could be regarded as questionable, just as Mrs Fairfield's statement, earlier in the section, that grapes need Australian sun to ripen is also questionable (since she herself has bought grapes grown in Wellington ${ }^{422}$ ). Andrew Gurr has discussed whether what is described here as an aloe could actually be an agave:

The agave americana, which is still to be found in the Botanical Gardens in Tinakori Road, Wellington, ... exactly fits the description in 'Prelude' in every detail except for the central stem, which should appear only immediately before the plant flowers and dies. The stem which Mansfield described in "Prelude" is either that of an agave about to burst into its unique flowering, or the spike of an aloe, which stands for year after year between flowerings, somehow transplanted by Mansfield's peculiar botany into the rosette of an agave. ${ }^{423}$

Gurr concludes that the aloe symbol in 'Prelude' is not intended to exactly reproduce a memory of a particular plant but to suggest "the daunting fears and pains of a lifetime, lived for a brief moment of flowering”. ${ }^{424}$ Another possibility for the aloe symbol is that it is indeed intended to represent an agave about to flower, since Linda's idea that it flowers once every hundred years suggests that it could be the "century plant”, a common term for the Agave americana; another term for this plant is the "American

418 Gurr, p. 205.

${ }^{419}$ Genesis 2 v. 9 and Genesis 3 v. 3.

${ }^{420}$ Genesis 3, vv. 3 and 5.

${ }^{421}$ KM Stories, p. 52.

422 Ibid., section III, p. 15.

423 Gurr, p. 203.

${ }^{424}$ Gurr, p. 205. 
aloe”, so Linda could be thinking of it by that name. ${ }^{425}$ Gurr has not taken the further step of linking this symbol to the mythical Agave, a woman who, in the frenzy of group Dionysian ritual, kills her own adult son (in the belief that he is a wild boar) by pulling off his head; her two sisters, who accompany her, each pull off one of their nephew's hands. This horrific myth, which is recounted at the end of the story 'Pentheus and Bacchus' in Ovid's Metamorphoses, ${ }^{426}$ can be read as background to the decapitation of the duck in section IX; here, it could anticipate that Linda (associated with Agave because Linda particularly identifies with the aloe) will one day participate in blindly murdering (in a metaphorical sense) the son she has not yet borne. The implication of this myth is the first of a darker series of images used satirically in the third quarter of 'Prelude' to connect the characters' personal responses to the text's implications of a wider social vision.

Section VII, which continues with the satirical approach begun in section VI, shows Stanley, Linda, and Beryl in turn each enjoying a sense of power and status that is sooner or later undercut. Stanley's rapid motion and impulse buying at the beginning of the section are an implicit contrast to the situation of the women of his household, who, like the aloe described at the end of section VI, are "becalmed" 427 in the sense that their freedom is restricted. However, Stanley's sense of adult identity and control (which depends on his being able to pick and choose whatever he likes to take with him, like Kezia in section $\mathrm{II}^{428}$ ) is subverted by child-related imagery. Pat's tucking Stanley's feet up recalls Lottie's and Kezia’s feet being tucked up by the storeman ${ }^{429}$ (section II) and Kezia being tucked into bed by her grandmother ${ }^{430}$ (section IV), so that the association gives Stanley the child role and Pat that of the adult. Pat "sitting up there” is higher than his master and has control of the buggy just as the storeman controlled the journey in section III and "towered beside [Kezia] big as a giant”431 (section II). Pat's later application of the brake, and Stanley's nervous reaction, is a

\footnotetext{
425 "Century plant: a plant, Agave americana, flowering once in many years ... also called American aloe." Concise Oxford Dictionary, $8^{\text {th }}$ ed. (Oxford: Clarendon Press, 1990), p. 182.

${ }^{426}$ Ovid, Metamorphoses, trans. A. D. Melville (Oxford: Oxford University Press, 1986), pp. 72-73. The variety of prose and verse translations of this work available before 1915 make it more likely that, in 'Prelude', any allusions to this work are via motifs and/or events rather than phrases, so for this reason a modern translation has been used.

${ }^{427}$ KM Stories, p. 34.

${ }_{428}$ Ibid., p. 14.

${ }^{429}$ Ibid., p. 15.

${ }^{430}$ Ibid., p. 21.

${ }^{431}$ Ibid., p. 16.
} 
reminder of Stanley's actual lack of mastery, which leads to the "sort of panic" he experiences on approaching home: his panic recalls Kezia’s in section II. ${ }^{432}$

Stanley's sense of control and mastery is also undercut by phrasal echoes, satirically intended, that connect his appreciation of people with his enjoyment of food. These overtones suggest that for Stanley there is not much difference between the two, which supports Fullbrook's idea that Stanley represents the male as "the devourer of life” ${ }^{433}$ - a role that, however, parallels Linda's as Agave. Stanley’s “First-rate!” and “a first-rate chap” with regard to Pat recall Stanley’s “Tip-top meat, isn’t it?”434 in section III. Similarly, Stanley’s mention of "three tip-top cows", with its echo of "firstrate chap", raises the question of whether the women at the house are equivalent in Stanley's mind to his cows - just as Pat's question “ 'Did she [the grey mare] satisfy yer, sir?'” suggests Stanley’s previous night with Linda. Stanley's enjoyment of the cherries he eats has overtones of human bodies ("so plump and cold, without a spot or a bruise on them"), especially when he compares two of them to "a perfect little pair of Siamese twins”. A similar effect occurs later when Stanley compares the cooked duck to an infant (section XI). ${ }^{435}$ A savagely satiric effect, as of a Cronos devouring his children, emerges.

Stanley’s sense of ownership, implied by "his own house”, recurs with "his Saturday afternoons and his Sundays”, for which he is planning his family's activities as well as his own. But with this sense of apparent mastery comes the beginning of its simultaneous unravelling: for example, thoughts of attending church bring associations with “the Sharpness of Death” (Mansfield's italics). The panic with which Stanley arrives at home is accompanied by sunset, which marks his own loss of power and the ascendancy of his wife's (with the later image of the rising moon).

Smith points out the similarity of Stanley’s arrival to that of Lottie and Kezia the previous night: "They are not sure of a welcome; the verandah, a threshold, is an area of anxiety for them as it is for their father."436 Linda's discreet distancing tactics as she cuts short his embrace and mildly mocks his gifts of pineapple, oysters, and cherries opposes Stanley's capture of herself ("he could hardly stop himself dashing up the steps and catching her in his arms") and symbolic production and devouring of their children - which the oysters (with overtones of fertility) and cherries (which he ${ }^{432}$ Ibid., p. 15.

${ }^{433}$ Fullbrook, Katherine Mansfield, pp. 74-75.

${ }^{434}$ KM Stories, p. 19.

435 Ibid., p. 50.

${ }^{436}$ Smith, KM and VW, p. 108. 
saw as "Siamese twins") might imply. The pineapple also suggests devouring of children because it is a slang term for a hand-grenade, ${ }^{437}$ the weapon that killed Mansfield's brother in October 1915. The hand-grenade of the First World War, the British Mills Bomb, was first used in the trench warfare of 1915 and had an "easily gripped pineapple shape”. 438 The “case of pine-apples”439 sent by Queen Victoria in the children's game in section VIII to cure a father's cold supports this possible link, as does the date when Mansfield wrote the relevant section of The Aloe. According to O’Sullivan, Mansfield "had written only to the end of the dance scene in Chapter II" of The Aloe by the end of April 1915 and did not return to the story until February 1916, a few months after her brother's death. ${ }^{440}$

Linda now takes control, leading Stanley first to the nursery and then to their bedroom, where she again keeps him at a distance; she avoids the dining room, in which Beryl has established a romantic atmosphere. Stanley’s feelings that he is "a perfect fool to feel as happy as this” and "so confoundedly happy” are already qualified by hints of his own foolishness and confusion. The references to the dew, coldness, and distance with which this part of section VII ends suggest Linda's own kind of power, one of remoteness, which is itself overwhelmed as Linda anticipates and fears being "strangely discovered in a flood of cold light” - which could be her selfdiscovery in section XI.

The final part of this section has fascinated commentators, who have speculated about Beryl's identity problems. Beryl's sense of power and identity, dependent on her outward appearance and hopes of romance, is ironically qualified by images that anticipate the fate of the duck: her white dress with black spots on it anticipates the white duck with blood on its feathers; and her phrase that she would (in the role of an admirer) be "rather struck" if she looked in and saw herself anticipates the striking of the tomahawk ${ }^{441}$ (section IX). The word “dressed”, ${ }^{442}$ which Alice uses to describe herself in section $\mathrm{X}$ (following the killing of the duck in section IX), reinforces the link between dressed poultry and costuming for a role, suggesting that both Beryl and Alice are victims of social processing for sexual and servant purposes.

\footnotetext{
${ }^{437}$ See definition for "pineapple”, Collins English Dictionary, $6^{\text {th }}$ ed. (Glasgow: HarperCollins, 2003).

438 The Macmillan Family Encyclopedia, vol. 9 (UK: Macmillan London, 1983), p. 358.

439 KM Stories, p. 40.

${ }_{440}$ O’Sullivan, ed., The Aloe, pp. ix and xii. Note that the year "1915” at the top of p. xii is a misprint for “1916”, since Mansfield could not have "addressed her dead brother” in February 1915.

${ }^{441}$ KM Stories, p. 46.

442 Ibid., p. 47.
} 
Beryl's sense of status is threatened by the appearance of Alice, from whom Beryl is as concerned to distance herself as Linda was from Stanley earlier in the section. Beryl's secret fantasy life is also exposed to Alice, who takes the part of comic moon as well as poultry at this point and so parodies Linda's fear of discovery by moonlight:

Beryl flung up her head and began to sing again:

"Even the moon is aweary ..."

But there came a loud bang at the door. The servant girl's crimson face popped through.

"Please, Miss Beryl, I’ve got to come and lay."

The similarity of actual status between Beryl and the "servant girl" has been well documented. Beryl's enthralment by "her pale shadow" at the end of the section reinstates her sense of identity, which anticipates the white ducks swimming with their reflections. The setting up and subversion of Beryl's pretensions is characteristic of the reversals of status in these first seven sections.

\section{Sections VIII to XI: “This whole process of becoming the duck”}

In her letter of 11 October 1917, quoted from more fully in the introduction to this thesis, ${ }^{443}$ Mansfield discusses her method with reference to the duck in 'Prelude':

When I write about ducks I swear that I am a white duck with a round eye, floating in a pond fringed with yellow blobs and taking an occasional dart at the other duck with the round eye, which floats upside down beneath me. In fact this whole process of becoming the duck (what Lawrence would, perhaps, call this "consummation with the duck ...”) is so thrilling that I can hardly breathe, only to think about it. ${ }^{444}$

Although this passage describes Mansfield's process of literary creation, she may also have had in mind, when referring to "this whole process of becoming the duck", the process that the duck signifies in 'Prelude', a significance that makes it "more duck" than it could "ever possibly be" ${ }^{445}$ in real life. Sections VIII and IX of the story are those that most fully explore the process of social and biological enslavement and impairment symbolised by the capture and death of the white duck.

Section VIII introduces this theme more explicitly than in previous sections (which have only hinted at it) by exploring, through the medium of children's games, the sense of identity based on ownership - concepts of owning and being owned.

${ }^{443}$ Pp. 7-8.

${ }^{444}$ KM Letters (O and S), vol. 1, p. 330.

445 Ibid., p. 330. 
Section IX follows the theme of ownership to its logical conclusion, that of social and biological exploitation. In sections IX and XI, the duck's decapitation for the dinner table is the symbol of that exploitation. Similarly to the key symbol of the aloe, that of the duck expands to take on a variety of implications, and its association with a number of characters well before and after section IX signals its importance in the text. (This technique is a development from the use of association in 'Juliet' and 'Brave Love', where the wheel image was linked to characters by phrases such as "down down down” ${ }^{446}$ in 'Juliet' and by the verb "turn” 447 in 'Brave Love'.) So terms used to describe Beryl at the end of section VII ("in a white muslin dress with black spots on it”, “rather struck”, “flung up her head”, "looked at her pale shadow”448) connects her sense of a romantic role with the life and death of the white duck.

Commentators on section VIII have recognised that the children do not conform to reader expectations of innocence and inexperience. Fullbrook states that:

The children, especially together, are in fact brutal parodies of the adults. The exception is Kezia, the most important single figure in the story, and the adults all function as teachers and potential teachers for the child's still open mind. ${ }^{449}$

Smith also argues for Kezia’s difference from the other children, pointing out that Kezia, in resisting “ 'playing ladies", ${ }^{450}$ in section VII, is:

engaged in sibling battles, and particularly in resisting the domination of her older sister Isabel who wants Kezia to conform to her gender role, and to her junior place in the family. ${ }^{451}$

New sees the children's games in section VIII as already participating in "adult social games" of sexuality, gender, and class and as hinting at childhood sexual curiosity. ${ }^{452}$ As well as having social implications, sections VIII as well as IX corroborate Toby Zinman's observation that “[t]he child's world is the perfect demonstration of the blurring of the distinctions between illusion and reality". 453

Section VIII certainly does refer to social games, controls, and hierarchies, and as such it implies, through the perspectives of the children, a view of social confusions

${ }^{446}$ KM Notebooks, vol. 1, p. 64.

447 Ibid., vol. 2, p. 50.

${ }^{448}$ KM Stories, p. 39.

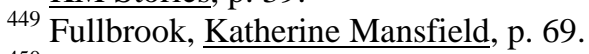

${ }^{450}$ KM Stories, p. 43.

451 Smith, KM and VW, p. 97.

${ }^{452}$ New, pp. 152-153.

${ }^{453}$ Toby Zinman, “'The Snail under the Leaf”: Katherine Mansfield’s Ironic Vision’ (USA: Temple University, 1973), pp. 221-222. (Dissertation) 
that also affect the adults. The first part of the section, in which Lottie, Kezia, and Isabel role-play a “luncheon party”, shows the children in 'Prelude' blurring the boundaries between different kinds of possession in a similar way to Stanley's confusion between his human, animal, and food possessions in section VII. The children's use of the verb "have” suggests that offspring (or dolls) and servants are equally kinds of possession: “ 'I have had another baby since I saw you last””; “ 'I’ve only had [the servant] two days””; “ 'Mrs Samuel Josephs had [a lady-help]’”. Possessive adjectives with nouns (“my twins”, “your husband”, “your new servant”, and so on) further suggest that the children's sense of identity is based on ownership that blurs the boundaries between animate (children) and inanimate (dolls). The children's dispute about whether a servant has enough status to be introduced recalls Beryl's determination in the previous section to keep Alice at a distance socially ${ }^{454}$ (section VII).

In this role-play, Kezia is the only participant whose sense of self is different, resting as it does in her creativity: like Mrs Fairfield in section VI, she focuses on the creative possibilities, not the social restrictions, of her servant role. In her letter from Mansfield to Brett dated 26 March 1920, Mansfield outlines her belief that artists are “the only free people”, thus enabled and duty bound (possibly through clearer vision than that of others) to make discoveries:

Why do you feel that you must make your discovery and that I must make mine? That just because we are artists and the only free people we are obedient to some law? There's the mystery! ${ }^{455}$

So sections VIII and IX juxtapose the implications of social and biological processing with the development of Kezia's creative vision, culminating in her contrasting view of the duck's decapitation to that of the other children and her protest against it.

When Pip and Rags appear, “They had a mongrel dog” has the same overtones of possessing and treating a living being as if it were an object, as in the "luncheon party” passage. Their dog, Snooker, is obviously at the bottom of the Pip-RagsSnooker hierarchy and, in the treatment of his head to which his owners subject him, he is a precursor to the duck in the following section. Commentators have neglected Snooker, but he has an important function in the story. The boys' torture of their animal in attempts to transform it into a socially approved product ("a fighting dog”) symbolises the conditioning implied in this section; and Snooker's almost total ${ }^{454}$ KM Stories, p. 39.

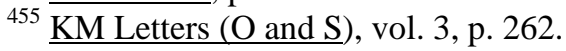


passivity in spite of his suffering qualifies Kezia’s image of “ 'rushing animals like dogs”" 456 (section III) and Linda’s of “my Newfoundland dog” who was sometimes "really frightening”457 (section XI). Snooker is docile, slinking, silent, and pathetically attached to his masters; yet Snooker aligns with aspects of Stanley. Snooker has "pale blue eyes” (Stanley’s are blue ${ }^{458}$ - section V); and Snooker's name suggests Stanley’s club. Linda's response to Snooker (“[Snooker] wanted to go into the house [from the front veranda] but wasn't allowed to because Aunt Linda hated decent dogs”) recalls Linda's rather cool welcome of Stanley on that same veranda the evening before ${ }^{459}$ (section VII) and anticipates her later thoughts that "[Stanley] was the soul of truth and decency” but that "she hated him" ${ }^{460}$ (section XI). Finally, Linda's affection for Stanley is expressed by her attention to his ears, ${ }^{461}$ which is similar to the boys' training of Snooker's ears. This implication of a vulnerable inner Stanley suggests the secret effects of being owned. Ironically, the image of the dog ill-treated by its boy owners is used to suggest the vulnerable inner self of a man. Pip’s calling Snooker "sir", and the fact that "Rags" is a typical name for a dog, ${ }^{462}$ support this connection.

Similarly, the girls' dolls are another example of being owned that is ironically related to the adult Beryl and Linda. Rags' "shameful” adoration of dolls is an ideal of tenderness qualified by its attraction to a mere object. Both Rags and Isabel seem to consider that dolls are high in status and in some way real. Similarly, the games that Isabel suggests at the end of the section are an extension of playing with dolls, with the roles of patients and children corresponding to the controllable, passive doll parts, and Isabel and Pip taking the controlling roles of parents, doctor, and nurse. So games with dogs and dolls are transferred to life roles of controlling and being controlled, similar to Linda's and Beryl's doll-like passivity of “waiting for someone to come who just did not come"463 (section V). Beryl waits for someone to fall in love with her physical appearance and frequent changes of clothes; ${ }^{464}$ Linda lies in bed, becoming "quiet, silent, motionless” ${ }^{465}$ like an object; and Stanley’s pathetic, doglike aspect of himself has already been suggested. (In one of Mansfield's letters to her husband, 23 and 24

${ }^{456}$ KM Stories, p. 17.

457 Ibid., p. 54.

${ }^{458}$ Ibid., p. 25.

${ }^{459}$ Ibid., p. 37.

${ }^{460}$ Ibid., pp. 53 and 54.

${ }^{461}$ Ibid., pp. 23 and 37.

${ }^{462}$ The fact that "Rags" is a typical name for a dog was suggested by my supervisor, Harry Ricketts.

463 Ibid., p. 28.

${ }^{464}$ Ibid., p. 39.

${ }^{465}$ Ibid., p. 28. 
May 1918, she refers to herself as a "poupée malade” [sick doll] in disparaging terms, since she is afraid that her illness is costing him too much:

As it is my illness has cost you an incredible number of armchairs and stair carpets and corner cupboards [...] Well, work as much as you like without overtiring your darling self, but work for the Heron [their intended home] but not for the poupée malade -$)^{466}$

Section VIII, then, portrays a process of conditioning that children and adults respond to by different combinations of role-play and resistance, as Kezia, for example, resists Isabel's choice of games but complies with the ill-treatment of Snooker, or as Linda is alternately cool and submissive to Stanley. The image of the bandaged “fighting dog”, which ends section VIII, suggests both war-inflicted wounds and impaired inner self and points forward to the decapitation of the duck, the drastic conclusion of the role-playing and conditioning processes.

${ }^{466}$ KM Letters (O and S), vol. 2, p. 188. 


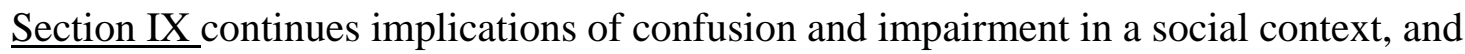
like section VIII it relates childhood to adult experience.

Where commentators have discussed this section, they have recognised its importance to the meaning of the story as a whole. For example, Hanson and Gurr state that:

the duck scene ... represents, in the worst possible light, what [Stanley] is doing to Linda and Beryl - he is "destroying" them by forcing Linda into unwanted childbearing, and by moving Beryl away from the town where she might find her longed-for suitor. ${ }^{467}$

Fullbrook expands convincingly on this view that the scene represents male domination:

The children's excitement at their inclusion in an adult "rite" of death is important ... they recognise power when they see it and respond with horrible glee ... The scene is a primal fall from innocence, and it is also a scene in which a male parent-figure initiates the children into slaughter. In 'Prelude' this is the core of masculine gender. The male is the devourer of life, the killer, and Pat's act is completed as male ritual later in the story where we see Stanley - associated with knives like the butcher in Kezia's nightmare in 'The Little Girl' - carving the same duck with professional manly pleasure. Kezia is only recalled from her terror through the evidence of Pat's likeness to women. ${ }^{468}$

Commentators have also linked the word "lid", with which Pat calls the ducks, to the top of the cream jar (at the end of the story) to suggest social restrictions; ${ }^{469}$ the top of the cream jar placed on the toy cat's ear, like the handkerchief over Snooker's ears, can also be read to suggest the related concept of social impairment.

When Pat first appears at the beginning of the section, the echo of the bedtime myths from section IV suggests the trust with which Kezia regards him. His "little tomahawk that winked in the sun” recalls Kezia's wished-for "Indian brave” in section IV; ${ }^{470}$ and Pat's holding out his hands to the children, his words " 'Come on now'”, and the phrase "He loved little children" recall the "Gentle Jesus meek anmile" 471 (who suffers “a little chile” to “come to [him]”) of Lottie's prayer. Pat's smiling at the children and coaxing them, however, has implications of trickery (as with Stanley Samuel Josephs' smiling at Kezia ${ }^{472}$ in section I and Pip’s enjoyment of foxing ${ }^{473}$ from section VIII) and anticipate Pat's coaxing of the ducks.

${ }^{467}$ Hanson and Gurr, p. 53.

${ }^{468}$ Fullbrook, Katherine Mansfield, pp. 74-75.

${ }^{469}$ New, p. 157; Fullbrook, p. 84.

${ }^{470}$ KM Stories, p. 21.

${ }^{471}$ Ibid., p. 22.

${ }^{472}$ Ibid., p. 13. 
The children's lack of clarity about what awaits them is shown in their comments. Pat's affirmative answer to Kezia's initial question “ 'Is it a real duck's head?'” is what decides her to accept his invitation, and the others follow. Her interest in what is "real" contrasts with the games and dolls of the previous section. (This concern with what is “real” matches Murry’s and Mansfield's emphasis on the reality of art in their 1912 manifestos: for example, "The journalist ... is the slave of the unreality of his own making. The artist frees himself by the realities he creates.” ${ }^{474}$ ) $\mathrm{New}^{475}$ has observed that the children are led across several boundaries to the ducks' habitat. These boundaries are also associated with abrupt movements down and up (down through the orchard, down a steep bank, and up the other side), anticipating similarly abrupt changes experienced by the ducks later. What the children see first in this setting is a picture of idyllic beauty:

Up and down [the ducks] swam, preening their dazzling breasts, and other ducks with the same dazzling breasts and yellow bills swam upside down with them.

This description suggests completeness, harmony, and also the childish blurring of boundaries between the real and unreal, since the reflections also appear to be actual “other ducks”. The scene has associations with the Burnells’ own habitat: the ducks have "made themselves at home" as the family have in their new house, and the pools themselves recall the water imagery often used to describe the characters and their new environment (for example, Beryl in a "pool of moonlight" 476 in section IV and the "big soft bubble of light on the ceiling” ${ }^{477}$ in section VII). Further, the ducks' "upside down” reflections recall other situations, such as Linda's notion that her children should stand on their heads ${ }^{478}$ in section I, Beryl's fascination with her reflection ${ }^{479}$ in section VII, and Pip's boast that he can walk on his head ${ }^{480}$ in section VIII. The children's (and adults') uncertainty about boundaries between real and unreal, identity and role, gives this image of the ducks and their upside-down reflections a further implication of distorted viewpoints. Mansfield's description of writing about ducks in

\footnotetext{
${ }^{473}$ Ibid., p. 42.

474 John Middleton Murry and Katherine Mansfield, rpt. in Hanson, ed., p. 23.

475 New, p. 153.

${ }^{476}$ KM Stories, p. 22.

477 Ibid., p. 38.

${ }^{478}$ Ibid., pp. 11-12.

${ }^{479}$ Ibid., pp. 39-40.

${ }^{480}$ Ibid., p. 43.
} 
her letter to Brett can also be read as suggesting that 'Prelude' is targeting the unreality of distorted perceptions:

When I write about ducks I swear that I am a white duck with a round eye ... taking an occasional dart at the other duck with the round eye, which floats upside down beneath me. ${ }^{481}$

Pat's description of the ducks as " 'the little Irish navy"” recalls the previous section's implications of social organisations and war. Pat himself is given ironic associations with the authority of kingship: he will show the children " 'how the kings of Ireland chop the head off a duck"”; his hat has a "broken crown"; and the walking but headless duck will be the "crowning wonder". Pat's "lazy" demeanour as he tempts the ducks up the bank from the stream recalls his persuasive behaviour with the children; but this relaxed attitude gives way to swift, violent actions as he grabs two ducks and decapitates one. The suddenness of the change from attraction to attack recalls other such contrasts throughout the story, as in Stanley Samuel Josephs' trickery of Kezia ${ }^{482}$ in section I, Linda’s dream of childhood to childbirth ${ }^{483}$ in section V, and Beryl's being attacked by the red ant while picking grapes ${ }^{484}$ in section VI. In all of these, attraction or harvest turns into being duped or harvested. The duck's decapitation (in the context of earlier overtones of war) has implications of death in wartime as well as of the physical aspects of sexuality ("Up spurted the blood"); in addition, the sentence "[Pip] nearly sobbed with delight when Pat gave the white lump into his arms" has overtones of birth and so ironically contrasts with Stanley's own longing for a son, whom he also has the propensity, as later wartime father, to metaphorically devour.

As implied in section VIII, Kezia is able to see differently to the rest. The other children's, and Pat's, emphases on looking at what's happening to the headless duck (Lottie’s “Look, Kezia, look”, Pat’s “Watch it!”, and Pip’s “Do you see that?”) contrast with and yet reflect the duck's inability to see, since very different ways of seeing are implied. Kezia's contrasting recognition of horror highlights how the reader should view the scene, using clues to interpret it more rationally.

As mentioned in the discussion of section VI above, section IX can be read as alluding to Agave's decapitation of her adult son, described in the story 'Pentheus and Bacchus' in Ovid's Metamorphoses. The two scenes contain similar elements of group ${ }^{481} \mathrm{KM}$ Letters (O and S), vol. 1, p. 330.

482 KM Stories, p. 13.

483 Ibid., p. 24.

${ }^{484}$ Ibid., p. 29. 
frenzy, decapitation, bloody hands, and radically different ways of seeing, which is particularly tragic in that the only person in the Ovid text who sees rationally and begs his mother and aunts to look is Pentheus, the victim:

... With no hands left to stretch

Out to his mother, "Look, mother!" he cried, And showed the severed stumps. And at the sight

Agave howled and tossed her head and hair, Her streaming hair, and tore his head right off, And as her bloody fingers clutched it, cried "Hurrah for victory! The triumph’s mine!"

As in section IX of 'Prelude', questionable ability to see ironically contradicts pleas or invitations to look.

After Kezia's initial question to Pat about whether the duck's head will be real, she is never mentioned again throughout the scene until near the end, whereas all the other children reacting to the duck's death are mentioned by name. This suggests that Kezia doesn't share the others' frenzy but is a shocked observer of their uncharacteristic behaviour ("Even Isabel leaped about ... Even Lottie, frightened little Lottie, began to laugh" - laughter that recalls that of the powerful in sections I, III, and IV). When Kezia does act, she "suddenly rushed at Pat and flung her arms round his legs and butted her head as hard as she could against his knees.” The language recalls her fear of rams and her statement that " 'I often dream that animals rush at me ... and while they are rushing, their heads swell e-enormous'”. ${ }^{486}$ She has reversed her role to become predatory, a “rushing animal”, repeating the suddenness of Pat's actions and his grabbing of the duck's legs. This aspect of Kezia is one possible interpretation of her identity.

Kezia's experience with Pat that ends the section has both spiritual and “animal” connotations. Pat's tenderness as he comforts Kezia contrasts with his violence to the duck, recalling the double-sidedness of experience and identity that was characteristic in 'Brave Love'. His actions of affirmation and love now restate the aspect of Pat that initially inspired trust in the children and recalled Lottie's garbled version of "Gentle Jesus meek and mild" in section IV. ${ }^{487}$ Fullbrook, arguing that "[T]he male is the devourer of life, the killer", also recognises this sense of the mythical in the passage, as Kezia "assumes the position of suppliant before the man

\footnotetext{
${ }^{485}$ Melville, trans., Metamorphoses, p. 72 (ll. 711-731).

${ }^{486}$ KM Stories, p. 17.

487 Ibid., p. 22.
} 
who has demonstrated his power of imposing death in an ordinary yet godlike display of authority." 488

Kezia's intuition of what the duck's beheading means can be read as being affirmed by Pat, who in contrast to his social and biological implications as killer now takes on overtones of knowing Kezia's deepest self. So the suggestions of the Christian church as controlling social force, as in Isabel's game of “playing ladies”489 (section VIII), are qualified by overtones of Christlike understanding of true identity. As Mansfield was later to state in a letter to Brett (29 August 1921):

It seems to me that there is a great change come over the world since people like US believed in God. God is now gone for all of us [...] But we must feel that we are known that our hearts are known as God knew us. Therefore Love today between "lovers" has to be not only human, but divine today. ${ }^{490}$

At the same time, Kezia’s experience with Pat recalls and anticipates examples of adult sexual love, with overtones of the self as object. “[Kezia] pressed her face into a bone in [Pat's] shoulder and clasped her arms round his neck” recalls Stanley embracing Linda in section VII: “[A]gain he put his arms round her and pressed her head into his shoulder." 491 Pat's affirming "There’s the grand little girl” anticipates Beryl’s fantasised comment from an admirer, "[Y]ou really are a lovely little thing”,492 (section XII), which affirms Beryl as sexual object only. So Kezia’s experience with Pat combines the contrasting intuitions of impersonal forces that impair identity and personal yet divine love that affirms it. The character of Pat represents both sides.

Pat's gold earrings, which Fullbrook sees as “evidence of [his] likeness to women”, ${ }^{493}$ can also be read as an image of totality (similar to the wheel image in 'Juliet' and 'Brave Love'), which attracts Kezia’s gaze slowly upwards. This experience anticipates Linda's similar moment of acceptance at the end of section XI, where the "round flowers" and their emphasised combination of red and white (the colours of the white duck and its blood) also suggest totality:

She had been walking with her head bent, looking at nothing. Now she looked up and about her. They were standing by the red and white camellia trees. Beautiful were the rich dark leaves spangled with light and the round flowers that perch among them like red and white birds. ${ }^{494}$

\footnotetext{
${ }^{488}$ Fullbrook, Katherine Mansfield, p. 74.

${ }^{489}$ KM Stories, p. 43.

490 KM Letters (O and S), vol. 4, p. 270.

491 KM Stories, p. 38.

492 Ibid., p. 58.

493 Fullbrook, Katherine Mansfield, p. 75.

${ }^{494}$ KM Stories, p. 55.
} 
(In a letter from Mansfield to Murry, 14 October 1922, Mansfield connects the circle image with vulnerability to the oppositions of circumstance:

I know just what you mean. It is as though one were the sport of circumstance - one is, indeed. Now happy, now unhappy, now fearful, now confident, just as the pendulum swings [...] So there one is - involved beyond words, feeling the next minute I may be bowled over or struck all of a heap. I know nothing.

This is to me a very terrible state of affairs. Because it's the cause of all the unhappiness (the secret, profound unhappiness) in my life. But I mean to escape and try to live differently. It isn't easy. But is the other state easy? And I do believe with all my being that if one can break through the circle, one finds "my burden is light."

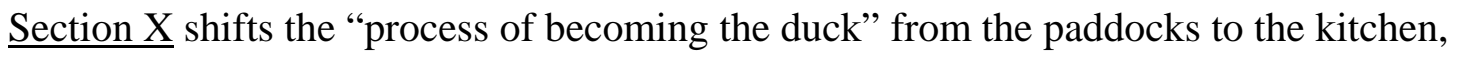
showing how that process works in Alice and Beryl. Alice takes the main role here since she is the lowest person in the household hierarchy and is connected most obviously and comically (in section XI) with the duck as social product. ${ }^{496}$ Her role has implications for Beryl as well, as commentators have been aware, and also for Linda.

The section begins by apparently contrasting the "warm, tidy kitchen” with the drama and messiness of the previous section. However, associations with the duck episode soon suggest that the same processes of social processing lie beneath the quiet surface. First, Alice describes herself as “ 'dressed”, a term that can relate to poultry as well as clothing. Her servant uniform is constricting in its heat and discomfort, and New has pointed out that the clock's tick, the rattle of the kettle lid, and the tapping blind also suggest constriction and limitation. ${ }^{497}$ Further, imagery of “water-cress sandwiches [...] a lump of butter on the table, a barracouta loaf, and the cresses tumbled in a white cloth" [my italics] includes terms used in or evoking the previous scene, suggesting that the kitchen is as dangerous a place as the paddock and the stream.

Alice's dream book imagery, in its bizarre mingling of sudden transformations of birth, death, financial acquisition, and falling "from great height”, revisits the violent events and personal and social implications of the previous section. Beryl's sudden arrival and Alice's reaction of hiding the dream book and dropping the knife recall the relationship of predator and prey: sudden attack, responded to by dropping (as Linda

${ }^{495}$ KM Letters (Murry), p. 255.

${ }^{496}$ KM Stories, p. 50.

497 New, p. 157. 
drops the baby into her apron in section $\mathrm{V}^{498}$ or Pip drops the duck in $\mathrm{IX}^{499}$ ) or concealment, like Kezia at the end of section I. ${ }^{500}$ Beryl's comments, which are all to do with the confused conviction that appearance reflects value, imply that the "shabby”, “ugly”, “common” qualities of the previous day's tea tray are an outcome of the same qualities in Alice; but Beryl's implications display the superficiality of her own values. Beryl’s “firm handling” of Alice suggests food preparation, as if Beryl were the servant and Alice the duck. And Beryl too is like the duck looking at its reflection: she makes Alice "feel low" to convince herself of her own "great height", yet (as commentators have been aware) Alice’s status implies Beryl's.

Alice’s reaction to Beryl’s “firm handling” is to create "an imaginary Alice”; and even though Alice is pleased by this version of herself, the actual words of her “thrust” are an echo of Beryl’s implied opinion: “ 'I may be only a common servant girl as doesn't know how to play the guitar, but ...’”. The fact that she never expresses her "thrust" out loud anticipates the never expressed, aloe-related, "sharp and defined"501 feelings with which Linda would like to surprise Stanley (section XI). So this section portrays the formation of self-image on the adult level, as it was suggested on the child level (in terms of objects) in the previous section. The duck sitting above its reflection is a confusion of high and low status, reality and appearance, clarity and distortion. Beryl's confusion about the status of her real self in relation to her false self is explicitly mentioned in The Aloe: "It was her other self, whose slave or whose mistress she was which? who had written that letter."502

The final lines of the section, Beryl's words in the dining room about a dress she wants to remodel, recall the reference at the beginning of the section to Alice's being “ 'dressed”"; and the band of black velvet over the shoulders suggests a yoke of servitude. Later references to this dress show that it is white with red on the shoulders, an association with the decapitated duck.

\footnotetext{
${ }^{498}$ KM Stories, p. 24.

499 Ibid., p. 46.

${ }^{500}$ Ibid., p. 13.

${ }^{501}$ Ibid., p. 54.

${ }^{502}$ The Aloe, ed. O’Sullivan, p. 74.
} 
The first part of section $\mathrm{XI}^{503}$ has been much noted by commentators, who have argued that Stanley's role of carver in this passage anticipates that of sexual predator later in the section; for example, Fullbrook points out the "professional manly pleasure"504 with which Stanley carves the duck. Though such commentary is consistent with the harshness of the satire associated with Stanley, this passage emphasises relationships between the processing of the duck and all the characters, with wider social implications as well. Here, Alice's appearance is explicitly compared to that of the basted poultry, and Stanley compares the duck, as "the first of the home products", with children as objects of parental conditioning (which hints at his own as well):

"My father would say [...] this must have been one of those birds whose mother played to it in infancy upon the German flute. And the sweet strains of the dulcet instrument acted with such effect upon the infant mind ... Have some more, Beryl?”

As in section VII, Stanley's musings refect back on him by suggesting a father devouring his children, and the mention of "the German flute" (given the First World War context in which 'Prelude' was written) includes Germany in the context of social conditioning. The passage has other "relationships" with the duck: the phrase that it "lay, in beautifully basted resignation, on a blue dish" is echoed shortly afterwards in the description of Linda, who "lay in a rocking-chair, her arms above her head". The term "a very superior jelly” links back to Isabel as "very superior" 505 (section I), to Mrs Samuel Josephs' "big jelly of a face”,506 (section I), and to Mrs Fairfield’s “high cap shaped like a jelly mould”507 (section VII). Even Stanley shares the duck's vulnerability, since the phrase "[he] ran his eye along the edge of the carving knife" is ambiguous, suggesting that he is carving himself. So as well as their children, the adult family members at dinner, eating the duck, are suggested as consumable products, like the "more pork" 508 at the end of section IV. The rest of section XI, and section XII, go on to further explore questions of reality and identity in the characters of Linda and Beryl (as well as of Stanley and Kezia).

${ }^{503}$ KM Stories, p. 50 to the first paragraph of p. 51.

504 Fullbrook, Katherine Mansfield, p. 75.

${ }^{505}$ KM Stories, p. 11.

${ }_{506}$ Ibid., p. 12.

${ }^{507}$ Ibid., p. 29.

${ }^{508}$ Ibid., p. 23. 


\section{Section XI continued: “One mysterious movement”}

The final pages of 'Prelude' bring the work to a conclusion and so must be "all compact of richness". ${ }^{509}$ These two sections are particularly interesting in that (as in the concluding sections of 'Brave Love') they allow the characters' minds to rove from one perspective to another, implicitly raising the question of whether any can be seen as most corresponding to reality. When commenting on the passages of section XI, critics have tended to overlook that movement, arguing instead for isolating and maintaining particular moments in the characters' thoughts, as if, for example, "Sex, cash, and death will create 'whole fleets of aloes', spiked emblems of hatred binding the woman whose mask will remain in place"; 510 whereas what seems to be depicted in 'Prelude' is a fluidity of elements that ironically qualify each other, both through changing processes and contrasting backgrounds. This fluidity confirms the "weaving and unweaving of ourselves" 511 that O'Sullivan suggests is characteristic of Mansfield's prose:

... that flickering of mood and atmosphere which, in the majority of the stories, prevents any feeling or perspective from lasting more than a short time in the narrative, or more than a few paragraphs in the text. ${ }^{512}$

In the drawing room scene, forces are implied that underlie the ordinary domestic surface. Linda, lying in her chair, "her arms above her head, rocking to and fro” recalls both the duck lying on its plate and the mechanical motion with which the live ducks swam "[u]p and down”" ${ }^{13}$ on the water (section IX). Beryl's removal of the light puts herself and Stanley into centre stage and Linda into the position of observer. Though only some of the perceptions in this scene are explicitly Linda's, her separateness from the other two characters recall other situations of separateness and vulnerability, such as when Linda is terrified of “THEM" and Kezia of "IT", and when Kezia observes the duck scene. Such precedents give a sense of imminent danger, a sense reinforced by (possibly Linda's) imagined warning to the moths, “ 'Fly out before it is too late’” and the "astonished” flowers of Beryl's painting of clematis. That awareness recalls Linda’s and Kezia’s perceptions of frightening

\footnotetext{
509 " [A]t the end, at the moment when the harvest is to be gathered - ah, then - at that final moment which should be all compact of richness [...]”: Novels and Novelists, p. 227.

${ }^{510}$ Fullbrook, Katherine Mansfield, p. 85.

${ }^{511}$ O’Sullivan, 'The Magnetic Chain', p. 139.

512 Ibid., p. 139.

${ }^{513}$ KM Stories, p. 45.
} 
transmutations between living and non-living, as when objects "come alive" in section $\mathrm{V}$, or when the headless, walking duck is neither alive nor dead.

What Linda sees in the scene in front of her is mysterious forces that involve pairs. It is Linda who comments to herself about the "one mysterious movement" set up by the rhythms of the game, a view that is continued in Beryl's or Linda's view of the cribbage pegs as two people pursuing each other around the game board. The "two little people” on the cribbage board are an example of the concept of pairs combined with that "mysterious movement". Linda's mention of "those two" playing their game is echoed in the other pairs in the passage, such as "two big moths" and "two kings". The implication of a circular movement is conveyed by the repeated word "round", which connects different parts of the scene and culminates in the flight of the moths: "Round her throat she wore an unfamiliar velvet ribbon”; “cribbage pegs ... turning round the sharp corner"; "round and round the circle of lamplight"; "Round and round they flew". (This repetition recalls the "down down down" ${ }^{514}$ relating to the wheel symbol in 'Juliet'.) The scene permeates living and non-living with the same motion, recalling Linda's fears of “this coming alive of things” 515 (section V) - a process in which the familiar becomes unfamiliar, as Beryl's “unfamiliar velvet ribbon ... changed her somehow - altered the shape of her face”. Possibly there is the suggestion that a role reversal could take place here, with Beryl becoming more important to Stanley than her sister (similarly to the potential role reversals between the female protagonists in “The Tiredness of Rosabel” [1908] and “A Cup of Tea” [1922]).

Also, the concept of a game being played recalls other games during the story, moving from Linda’s, Kezia’s, and the Samuel Josephs’ reversing their circumstances in fantasy in section I through to the children's (social) games in section VIII and anticipating the tennis games and Kezia's toppling toy cat in section XII. Many of these involve reversals, reflections, and objects subjected to forces. As New has pointed out, always in 'Prelude' "some kind of game happens"; New argues that "the games the characters play ... are [always] the agencies of social training”. 516 However, the fact that the duck's decapitation, presented as an entertainment for children, has overtones of birth, death, and sexuality as well as social impairment or exploitation links the concept of games to wider levels than just the social. The "one

\footnotetext{
${ }^{514}$ KM Notebooks, vol. 1, p. 64.

515 KM Stories, p. 27.

516 New, p. 148.
} 
mysterious movement” emanating from the cribbage game (recalling the ducks swimming around the pond) is extended through all dimensions.

Throughout this passage, Linda has been the observer of the action, like Kezia in section IX. ${ }^{517}$ Linda's sense of danger is suggested in her thoughts of warning to the circling moths: “'Fly away before it is too late. Fly out again’”. As Kezia did in section IX, Linda suddenly breaks out of the position of observer, perhaps heeding her own warning to the moths.

The few lines in which Linda is described as entering the nocturnal garden scene introduce it by linking that scene to earlier ones:

The moon that Lottie and Kezia had seen from the storeman's wagon was full, and the house, the garden, the old woman and Linda - all were bathed in dazzling light.

"I have been looking at the aloe," said Mrs Fairfield. "I believe it is going to flower this year. Look at the top there. Are those buds, or is it only an effect of light?”

The first three lines remind the reader of the children's night journey with the storeman (the first part of section III) as well as of Linda's anticipation that "the moon had risen - that she was being strangely discovered in a flood of cold light”518 (section VI). Also, Mrs Fairfield's observation about the aloe recalls Linda's and Kezia's encounter with the aloe at the end of section VI. The following half-section has elements of all three in that Linda's fantasised journey on the aloe as ship parallels the children's night journey and portrays Linda's self-discovery. This half-section also questions whether this self-discovery is one of birth or death.

Linda's feeling that the aloe is coming towards them and that she could depart on it subjects the aloe to a to-and-fro movement like the one she has seemed to perceive inside the house. The lights in the early part of section III, especially the "moon [that] hung over the harbour" and the mention of the Picton boat coming in "all hung with bright beads”, 519 anticipates Linda's view of the aloe as a ship coming towards her, on the oars of which "bright moonlight hung ... like water". Similarly, the following passage from section III is linked to section XI:

${ }^{517}$ KM Stories, pp. 45-46.

${ }_{518}$ Ibid., pp. 38-39.

${ }^{519}$ Ibid., p. 16. 
Now everything familiar was left behind. Now the big dray rattled into unknown country, along new roads with high clay banks on either side, up steep, steep hills, down into bushy valleys, through wide shallow rivers. ${ }^{520}$

The corresponding passage in section XI (page 53) is: "Now the oars fell striking quickly, quickly. They rowed far away over the top of the garden trees, the paddocks and the dark bush beyond.”

Though there are no exact verbal echoes except the initial word "Now", the concept in both passages is that "everything familiar was left behind" as the travellers in their ship and dray move "far away", "beyond” a progression of localities. Both passages convey a sense of freedom after the interior scenes that preceded them, and they are juxtaposed in that one is real and experienced by a child entering life, and the other is the fantasy of an adult facing the possibility of her imminent death. The connection of the two journeys not only suggests the unity in the disparate (child and adult, life and death, reality and fantasy) but also projects a future in which the adult children too will be subjected to that movement (implied by the aloe as boat) to other shores. So the "one mysterious movement" permeates past and future.

Linda's fantasised journey also relates to the duck scene. The start of that journey, when she is "caught up out of the cold water" and when "the oars fell striking quickly, quickly”, recalls the ducks’ leaving the stream, their being "seized”, and the rapid downward movement of the tomahawk. ${ }^{521}$ The experience of the aloe is merged with the experience of the ducks, connecting the two symbols and the themes of capture and escape, life and death. The sublime and the horrific approaches qualify each other, combining all into the "one mysterious movement" that Linda was aware of in the house and found extended in the cyclic movement of the moon and her and her mother's movement (as a pair) around the garden. The implication of that allpervasive movement goes beyond the personal and social: it recalls the unity of impersonal forces and mythical affirmation of identity in the character of Pat; it also recalls the wheel of necessity suggested in 'Juliet' and 'Brave Love'. That allpervasive movement accompanies Linda's progress of self-discovery as she and her mother walk around the garden in a movement that finally returns them to the house.

Within the frame of the “one mysterious movement”, Kezia’s discussion with the storeman about "rushing animals" in section III anticipates, in section XI, Linda's

${ }^{520}$ Ibid., p. 17.

${ }^{521}$ Ibid., pp. 45-46. 
fears and hatred of Stanley, of childbirth, and of death - encapsulated in the sentence "She had always hated things that rush at her, from a child". ${ }^{522}$ The passage in which Linda encounters her feelings about Stanley has been much discussed, with commentators agreeing on Stanley's role of sexual predator and on Linda's responses of hatred, illness, and longing to escape. Stanley has been seen only in negative terms, and earlier negative readings of Linda (for example, her "unwillingness to create or to work with the harvest of offspring”, ${ }^{523}$ ) have given way to positive readings of Linda as resisting the male threat; for example, Smith, in discussing shifts in perception of gender role in 'Prelude', sees Linda as

appropriating the aloe, which at first represented masculine dominance, and making it her ship; she casts herself as a kind of Flying Dutchman who is seeking to avoid rather than find a mate. ${ }^{524}$

Certainly the nature of Linda's feelings about Stanley is explicit and clear, giving the impression that her aloe journey is one of recognition and insight. Linda's thought processes are associated with aloe imagery: "at the sight of [the long sharp thorns] her heart grew hard”; "She knew him through and through”; “There were all her feelings for him, sharp and defined”. Her thoughts are also associated with suggestions of insight: "Yes, yes, it was true"; "It had never been so plain to her as it was at this moment.” These connections, recalling the combined imagery of eyes and flowers in the previous half-section (the "surprised-looking clematis") suggest that the flowering of the aloe parallels Linda's insight as well as her desired journey away from Stanley.

However, Linda's viewpoint is qualified by terms recalling the confusion between living and non-living, ownership and identity, and real and non-real from sections VIII and IX. So Linda in this section sees Stanley as "my Newfoundland dog”, which recalls the ill-treatment of Snooker as possession. The dog associations (continuing to "as though he were going to leap at the moon for her") also merge with implications of objects: "she had always hated things that rush at her, from a child." The ambiguity in this last sentence suggests that the hated "things that rush at her" include her children, whom she also, consciously, thinks of as "three great lumps" (recalling her section I phrase "a lump of a child" ${ }^{\text {"25}}$ ). At the same time, it is the aloe

${ }^{522}$ Ibid., p. 54.

${ }^{523}$ Magalaner, p. 38.

${ }^{524}$ Smith, KM and VW, p. 100.

${ }^{525} \underline{\text { KM Stories, p. } 11 .}$ 
(which could also be described as a thing) that Linda is most drawn to in this section: "I like that aloe. I like it more than anything here."

This attraction to and, indeed, identification with the aloe ("at the thought of [the long sharp thorns] her heart grew hard”) accompanies Linda’s withdrawal from people: "Linda snatched her hand from [her?] mother's arm” recalls Lottie in section IX after the killing of the duck: "When Isabel went up to Lottie, Lottie snatched away." "526 Linda's insight that "she hated [Stanley]" could therefore be enjoyable to her, parallel with the enjoyment of the group when seeing the duck killed. The possible identification of Linda with Agave in section VI could also subvert the emphasis on the clarity of Linda's insight here, since Agave's delusive view of her son as a wild boar is comically diminished in Linda's view of Stanley as a dog.

However, Linda’s experience also resembles Kezia's insight that the decapitation is horrific. The times "when [Linda] had just not screamed at the top of her voice: 'You are killing me!'” recall Kezia’s actual protest “ 'Put head back! ...' she screamed” ${ }^{27}$ (section IX). Also matching Linda’s diminishment of Stanley to an animal, her phrase "He longed to serve her” is a pun twice over, with meanings reminiscent of Stanley's carving the duck as well as of animal copulation, suggesting Stanley's own diminishment of Linda to food and animal status.

So the question of whether Linda's insights about both Stanley and herself are true or deceptive is left to the reader - a question prompted by Linda's repetition of the words "real” and "really" in this passage. Similarly, Linda's aloe journey also combines overtones of birth and death: the fact that she "particularly liked the long sharp thorns” recalls Stanley's quotation about "the Sharpness of Death”" 228 (section VII); and her posture of folding her arms and bending her head, "looking at nothing”, suggests the foetal position, that of a child in the process of being born. The process she is undergoing implies both, or one becoming the other. This combination of birth and death can pose the question of "where death ends and resurrection begins" as Mansfield has it in a letter to Dorothy Brett, 9 October 1922:

Life is a mystery. We can never get over that. Is it a series of deaths and series of killings? It is that too. But who shall say where death ends and resurrection begins. That's what one must do. Give it, the idea of resurrection the power that death would like to have. Be born again and born again faster than we die

${ }^{529}$ KM Letters (Murry), vol. 2, p. 253. 
Although until now she has been "looking at nothing”, Linda now looks “up and about her": "Beautiful were the rich dark leaves spangled with light and the round flowers that perch among them like red and white birds.” This image, generally neglected by critics, is one of completeness, combining light with darkness and using roundness as a symbol of totality; it suggests a moment of acceptance. The moment recalls Kezia's surprise when looking up and seeing Pat's earrings ${ }^{530}$ (section IX). This resemblance suggests that Linda has been through an experience of equal intensity to Kezia's on that occasion (and Mrs Fairfield's question about whether Linda is trembling recalls Rags' "shivering all over” after the decapitation ${ }^{531}$ ); the resemblance also implies that Linda is surprised by the contrast of the camellias' beauty with the negativity of her hatred and cynicism.

Linda's movement away from that moment of hatred is completed by selfforgetfulness. The crumpled verbena that Linda holds out to her mother in a gesture of reconnection can be read as suggesting sacrifice, since "verbena” comes from a Latin word meaning "sacred bough used by the priest in religious acts”. ${ }^{532}$ (Different definitions of "verbena" relate the word to Christian and pagan tradition: the common verbena was called "herb-of-the-cross", traditionally used to stanch Christ's wounds after the crucifixion; it is also associated with Roman, Greek, and Druid rituals.) Mrs Fairfield's reaction to the scent (“'Delicious”") is a food-related response, recalling the alignment of Linda to the cooked duck earlier in the section as she lay in the rocking chair, so Linda's gesture and her mother's response connect sublime and satiric. C.K. Stead's comment on Linda in 'At the Bay' can also apply to Linda in section XI of 'Prelude':

In 'At the Bay' Linda Burnell comes to accept the negative elements in the relations of the sexes and to affirm the whole process, even by implication the early death she seems to feel threatening her as a consequence of repeated child-bearing. ${ }^{533}$

Linda's recognition of the beauty of the trees and their round flowers suggests her acquiescence with the cyclic, resulting in sacrifice. The cyclic also involves Kezia, since her eventual movement “just away” as an adult will return her (via this story) to

${ }^{530}$ KM Stories, p. 47.

531 Ibid., p. 46.

532 Collins English Dictionary, $6^{\text {th }}$ ed., p. 1783.

533 C.K. Stead, 'Katherine Mansfield: The Art of the "Fiction”, The New Review, London (September 1977); rpt. in C.K. Stead, In the Glass Case (Auckland: Auckland University Press and Oxford University Press, 1981), p. 46. 
her origins; both Kezia and 'Prelude’ are “home products”, as is Kezia’s brother, unborn in the story.

Mansfield's own philosophy of acceptance, probably only consciously formulated later than in 'Prelude', is stated in her “confession” of 13 December 1920:

I do not want to die without leaving a record of my belief that suffering can be overcome. For I do believe it. What must one do? There is no question of what Jack calls passing beyond it: this is false. One must submit. Do not resist. Take it. Be overwhelmed. Accept it fully - make it part of Life [...] As in the physical world so in the spiritual world - pain does not last for ever. $^{534}$

Mrs Fairfield's answer to Linda's question about what her mother has been thinking of demonstrates the difference yet similarity of her thoughts to Linda's. The difference reinforces the concept of two people involved in the same circular movement but unable to communicate. The similarity, however, is in Mrs Fairfield's preoccupation with "home products" which, though on a very different level, have also been the subject of Linda's thoughts and were first mentioned (by Stanley and in a satiric context) at the beginning of the section. Mrs Fairfield's emphasis on the desirability of such products ironically reinforces the point Linda has reached - having possibly travelled through her hatred to arrive (perhaps only briefly) at a resignation to sacrifice. The theme of "home products" now leads to further questioning of what those home products are.

${ }^{534}$ KM Notebooks, vol. 2, pp. 201-202. 


\section{The buried self}

In section XII, the focus has moved from wider implications of the "one mysterious movement”, including sacrifice and harvest, to the present moment of the character, author, and reader and what should be done in that present moment. The concept of the buried self is similar to what Mansfield referred to as "the secret self we all have" when discussing 'At the Bay'. ${ }^{535}$ In this section of 'Prelude', the implied theme of hidden, multiple selves now becomes explicit.

Mansfield’s journal note, dating from some time after March 1916, about her treatment of Beryl in this section is well known:

What is it that I'm getting at? It is really Beryl's 'Sosie' [double]. The fact that for a long time now, she really hasn't been even able to control her second self: its [sic] her second self who now controls her. There was [a] kind of radiant being who wasn't either spiteful or malicious [...] Had she banished this being or had it really got simply tired and left her. I want to get at all this through her just as I got at Linda through Linda. To suddenly merge her into herself. ${ }^{536}$

In discussing the character of Beryl in this section, commentators have emphasised psychological and feminist messages. Magalaner stresses Beryl's "problem of identity” and sees her as "powerless to bring the two parts of her being, the girl and the mask, together"; the identity theme is seen as part of a "larger motif of illusion and reality in life which permeates 'Prelude', ${ }^{537}$ Later commentators have tended to follow this lead, attributing Beryl's problem to society in general and male domination in particular. Dowling sees Beryl's "acute schizophrenia” as the result of trying to "maintain several impostures at once": clandestine sexual activities (explicit only in the later Burnell stories) as well as the role of a candidate for a high society marriage. ${ }^{538}$ Feminist writers see Beryl as a victim of her own illusions; for example:

She constantly succumbs to the temptation of picturing herself ... as the passive heroine of an Edwardian Mills and Boon romance, who can emerge in her true colours only through the eyes of Mr Right. ${ }^{539}$

Hankin, approaching 'Prelude’ from a Freudian viewpoint, considers that Beryl is Mansfield's “confessional” version of herself as a teenager just as Kezia portrays Mansfield as a child, and therefore that Kezia and Beryl are the same person. ${ }^{540}$ As

${ }^{535}$ KM Letters (O and S), vol. 4, p. 278 (letter to Brett, 12 September 1921).

536 KM Notebooks, vol. 2, p. 27.

${ }_{537}$ Magalaner, p. 34.

538 Dowling, p. 152.

539 Anne Else, 'The Insipid Doctrine: Joining the Resistance in New Zealand', Women’s Studies Journal (December 1988), p. 45.

${ }^{540}$ Hankin, Confessional Stories, p. 131. 
they have with Linda, commentators have tended to consider particular aspects of Beryl as fixed; they have tended to overlook the multi-layered qualifications and questionings of the character and the ways in which Beryl's character relates to that of Linda, which helps to add dimension to both characters.

Beryl's letter to Nan Pym is full of ironies that reflect, in a minor key, Linda's experience in the previous section; in fact, her letter presents a side of herself just as hatred of Stanley represents one aspect of Linda. Beryl's complaining about Stanley in her letter parallels Linda's thoughts of hating Stanley; and Beryl's opinion of her letter (“She felt all those things, but she didn't really feel them like that”) could just as well be used by Linda to sum up her thoughts of Stanley.

Yet, in contrast with the intensity of Linda's experience, Beryl's letter appears slight and superficial; and, like Beryl's judgments of Alice in section X, the letter's disparagements are in terms of basing value on appearance. Beryl’s letter also includes flippant references to social death and burial; this fear of social death parallels Linda's fear of actual, physical death in the previous section. So Beryl feels that she is "buried, my dear. Buried isn't the word" and that "It's a sad ending for poor little B." Similarly, the word "rot" is associated with Beryl ("What rot. What nonsense. It wasn't her nature at all” and [section VI] “ 'One may as well rot here as anywhere else, ${ }^{541}$ ). So the Beryl of the letter already feels that on some level, she has died; and indeed her letter's "voice ... high, gushing, with something bitter in the sound" resembles the spurting blood of the decapitated duck ${ }^{542}$ (section IX). These suggestions of death recall the implications of sacrificial death in the previous section.

However, the comparison of Beryl's and Linda's situations is ironic, since Beryl is expecting liberation through marriage, whereas marriage means capture and sacrifice to Linda. This irony implies that Beryl's loss of her "real self” is a consequence of fixation on marriage: because Beryl is "always acting a part” to attract male attention, Beryl’s “real self” is undeveloped and possibly dying; and Linda, "Mysterious as ever" to Beryl, may also have either lost her real self or have it reborn in a form of hatred. Though Linda doesn't think in terms of true and false selves, her actions (of role-playing what Stanley wants to hear ${ }^{543}$, for example [section IV], or turning her head away when she passes the mirror ${ }^{544}$ [section V]) suggest that she too

${ }^{541}$ KM Stories, p. 31.

542 Ibid., p. 46.

543 Ibid., p. 23.

${ }^{544}$ Ibid., p. 28. 
is "hiding something", as she feels that the aloe is ${ }^{545}$ (section VI). In fact, the idea of the aloe's "hiding something” relates not only to Linda's possible pregnancy but also to the hidden selves of the characters, which may be in the process of being born or dying - as the process through which Linda passed in section XI suggested both. (This theme is similar to that in 'The Daughters of the Late Colonel', of which Mansfield commented in a letter to William Gerhardi [23 June 1921] that at the end "my two flowerless ones ... died as truly as Father was dead”, ${ }^{546}$ )

Beryl's efforts to grapple with her "real self" and "false self", which the language suggests she must have been aware of before this scene, imply that (like Kezia's uncertainty about which is "really Lottie"547 in section II) Beryl is uncertain which is which. Beryl is convinced that the false self has written her letter's “twaddle”, but the letter's satiric depiction of "Stanley’s men from the club” has an element of similarity to the narrator's duck imagery. Those men have "toes that turn in rather - so conspicuous when you are walking about a court in white shoes” (of course, playing tennis, they are wearing white); and they are intended for slaughter ("In fact, two are promised as a great treat to-day"). It gradually becomes apparent through the letter that Beryl is expecting to play tennis with such men from the club on that same day, for which purpose she also is wearing white. Finally, Beryl's red-trimmed, blackyoked white satin dress with which the letter ends seems to associate her too with the ducks as social product.

Beryl's turning to her mirrored reflection instead demonstrates the same assumption as in her letter to Nan - that attractive physical appearance determines value. Her confusion between identity and appearance is expressed in her complacent itemising of her physical features in terms of ownership ("Her face”, "Her eyes”, "her best feature", and so on), with the self-satisfied comment that "she was so awfully critical of herself”. As Else has mentioned, Beryl's loss of individuality is signalled as her own voice is "lost in" that of her imagined admirer. ${ }^{548}$ Her view of herself is ironically associated with the duck and its death, in terms of her white clothing, ready for playing tennis, and of the motif of her head being dragged back.

Beryl's recognition that she is "back again, playing the same old game" suggests that she has been in this situation often before, a situation aligned with the

545 Ibid., p. 34.

${ }^{546}$ KM Letters (O and S), vol. 3, p. 249.

${ }^{547}$ KM Stories, p. 14.

${ }^{548}$ Else, p. 45. 
social and mechanical role of playing tennis. She now decides that the false self is the one that is "always acting a part", but as in section IV, the artifice of Beryl's acting is connected with the allure of nature. ${ }^{549}$ Beryl's drive to fascinate is expressed in terms of light and the loftiness of the aloe. "She even kept it up for Stanley's benefit” and ”It’s marvellous how you keep it up” relate to "there sprang up a tall stout stem" 550 (section VI); and her eyes, eyebrows, and hair reflect the light like the aloe buds, which have seemed to Mrs Fairfield "an effect of light” 551 (section XI). So Beryl’s flowering sexuality and the artifice that enhances it are as much aloe-related as is Linda's hatred. Thus the two final sections can be read as paralleled, contrasting Linda's fear of sex (or fear of childbearing) with Beryl’s longing for sex and marriage but blindly ignoring such aspects as how childbearing will affect her "tiny waist". Through the voice of an imagined admirer, this sexual side of Beryl's self is emphasised as "really" no more than an object: “' 'Yes, my dear, there is no doubt about it, you really are a lovely little thing.'”

Beryl's reaction to the recognition that she is "False - false as ever ... False even when she was alone with herself, now" is to drop "down to one side of her bed" in a position that she later calls "kneeling in that idiotic way". The similarity to prayer in this physical position (though Beryl is not literally praying) is supported yet qualified by the precedent of Lottie's comically distorted bedside prayer ${ }^{552}$ in section IV; the fact that Beryl "buried her face in her arms" can be read positively or negatively, since it impairs her physical but enables her inward sight (and continues the emphasis on the burial of this character). The similarity to prayer is also suggested by the preceding expletive "God” (“Oh, God, there she was, back again, playing the same old game”) and by the penitential, confessional nature of her recognition ('I know that I'm silly and spiteful and vain ... How despicable! Despicable!”). So Beryl’s glimpse of a more true identity has overtones of prayer, similarly to the end of section IX, where Kezia's protesting rush at Pat, followed by his affirmation of her inmost self, recalls in a qualified way the "Suffer me to come to thee" ${ }^{, 53}$ of Lottie's prayer. In fact, Lottie's prayer anticipates both Kezia's and Beryl's qualified approaches to true identity.

If Beryl's process of self-discovery is similar to prayer, she is not praying to God but arriving briefly at a concept of self and life as "rich and mysterious and good”. ${ }^{549}$ KM Stories, p. 22.

550 Ibid., p. 34.

551 Ibid., p. 52.

552 Ibid., p. 22.

${ }^{553}$ Ibid., p. 22. 
The "unsubstantial" combination of light and shadow of which this sense of self and life is made up ("She saw the real Beryl - a shadow ... a shadow. Faint and unsubstantial she shone”) contrasts with being a merely physical "thing”; it also recalls Linda's sense of a life that combines both light and darkness, expressed in the camellia trees ("Beautiful were the rich dark leaves spangled with light and the round flowers that perch among them like red and white birds" 554 - section XI). Beryl's moment of recognition is what everything has been leading up to, just as Linda's moment with the camellias is the crucial point. The idea of Beryl's buried self is succeeded by the potential for the renewal or resurrection of an insubstantial "real self”. However, the other two possible selves (the "voice of the letter” and the physical appearance) also have aspects of reality about them, since the "voice" has aspects of the duck, and the physical self has aspects of the aloe. This possible "real self" is the least substantial, the most ideal, of the three.

As “[a]t the sound of the magic word 'man', Beryl snaps back to attention, once more on display", 555 so, similarly to Linda in the garden, she returns to her starting point. Beryl's rapid movement through the door, implied as continuing downstairs, recalls Kezia's (also rapid) downstairs movement at the end of section II, pursued by forces beyond her control that are both imagined and real; just as Linda, appearing in the kitchen in section VI, is implied to have escaped downstairs from “THEM”. All these movements are part of the wider, cyclic totality.

In a letter to S. S. Koteliansky of August 2 1922, Mansfield referred to her concept of "slave" and "free" in a way that provides a further gloss on Beryl's experience:

The born slave cannot become a free man. He can only become free-er. I have refused to believe that for years, and yet I am certain it is true, it is even a law of life. But it is equally true that hidden in the slave there are the makings of the free man. ${ }^{556}$

As Mrs Fairfield has the last word in section XI, Kezia has it in section XII. Kezia’s entrance follows directly on, and answers, Beryl’s final question (not given in quotation marks in the text, as if it merged with the author's own question about herself) “And was there ever a time when I did not have a false self?” Kezia’s entrance could suggest that childhood is a time of purity and truth, with no "false self"; but her "very dirty calico cat” implies otherwise - it could signify her own "false self”. Calico ${ }^{554}$ Ibid., p. 55.

${ }^{555}$ Else, p. 45.

${ }^{556}$ KM Letters (Murry), vol. 2, p. 234. 
is defined as "a white or unbleached cotton fabric with no printed design", ${ }^{557}$ which associates the toy cat with the white duck and with Beryl's white clothing. This object, carried under Kezia's arm and then impaired with a cream jar over its ear, recalls the dirty Snooker, who "stank abominably", bandaged over his ears ${ }^{558}$ (section VIII) and the two ducks carried by Pat, one under each $\operatorname{arm}^{559}$ (section IX). The toy cat could therefore represent the corruption, impairment, and capture examined in earlier sections. As mentioned above in this thesis with reference to 'Brave Love', Nelson Wattie has argued that "the corruption that causes Katherine Mansfield to cry out is the corruption of the cosmos itself”, 560

Kezia's directive to her toy cat to " 'Now look at yourself"” can be read as addressed to the reader as well as parodying Beryl’s fascination by her reflection. That directive is immediately qualified by the complex, multidimensional background that suggests the difficulty, and perhaps impossibility, of doing so: the images of the tumbling cat, the rolling lid, and Kezia’s being "hot all over” like the cooked duck reiterate aspects of the "one mysterious movement" to which characters, author, and reader are subject. However, the rolling lid has also been read as an image of vulnerability of the impairing social codes themselves: Fullbrook has related the top of the cream jar to Pat's call to the ducks, “ 'Lid. Lid-lid-lid-lid”, with the suggestion that the top represents "established cultural codes” ${ }^{561}$ that could one day break for Kezia.

Kezia’s directive recalls her similarly brief, similarly closing imperative to “ 'Put head back!'” in section IX - impossible to carry out in the case of the duck, but perhaps possible in the context of human, socially imposed impairment. That Mansfield believed self-regeneration to be possible is evident from a letter to Koteliansky of 4 November 1921, containing the statement “... for a long time I have been trying to 'squeeze the slave out of my soul'." (Here Mansfield was quoting Chekhov's description of a fictional character overcoming their own insincerity caused by impairment by social codes. ${ }^{562}$ ) So a didactic strand in Mansfield’s work cannot be ruled out. Shortly before 'Prelude’ was published, Mansfield wrote to Murry on 5 June 1918:

${ }^{557}$ Collins English Dictionary, $6^{\text {th }}$ ed., p. 240.

558 KM Stories, pp. 42 and 44.

559 Ibid., p. 45.

${ }^{560}$ Wattie, p. 152.

${ }^{561}$ Fullbrook, Katherine Mansfield, p. 84.

${ }^{562}$ Ibid., vol. 4, p. 312; see also note 1 on the same page. 
I explained to [Anne Drey] last night what I meant by religion. I feel awfully like a preacher sometimes - I really have a gospel - this seemed rather to startle her. $^{563}$

The two final sections question whether there is a real self separate from the drives to procreation, gain, and social acceptance, or whether this real self is simply a myth. This implicit questioning is partly directed at the social institution of marriage. Linda's mysterious self, possibly buried through marriage (she is as "Mysterious as ever” to Beryl), is paralleled with Beryl's buried self that (she feels) can only be discovered by marriage. The final sections therefore include the implicit question whether the focus on being and staying married is "death to a woman’s personality" 564 (as expressed in 'Juliet'). In 'Brave Love', the question of marriage is also central, since it represents a major difference of opinion between the two main characters. (Mansfield's greatly varying responses to marriage as an ideal and a bourgeois tradition are suggested by Alpers, who describes her as “divided ... about this bourgeois joy"565.) The theme of the buried self in 'Prelude' is not only related to female characters: Stanley too has a buried self. A concealed aspect of Stanley, implying how marriage affects him, is suggested in the pathetic Snooker (impaired by those he is devoted to); the effect of Stanley's work is expressed in a burial image: "Ah, it was splendid to live in the country - to get right out of that hole of a town once the office was closed". ${ }^{566}$. Stanley is as inwardly damaged by social institutions as any other character in the story.

Burial as a theme, however, goes beyond the social to wider implied dimensions in 'Prelude'. This theme is implicitly connected with germination and growth, seen in 'Prelude' in the pervasive plant imagery. The story's many images of confinement anticipate the theme of burial and imply potential for birth or death, for example, in section II, where Kezia's escape from the abandoned house suggests both, and in section VII, where Kezia's exploration of the garden implies the birthing of creativity, paralleled by the flowering of the aloe. This view permeates an individual life with birth and death events, incorporated in the "one mysterious movement" envisioned by Linda. So the characters' actions, imbued by an up and down movement from level to level and by changes of viewpoint about themselves and existence, both play out against the background and relate to the natural processes implied or depicted ${ }^{563}$ KM Letters (O and S), vol. 2, p. 219.

564 KM Notebooks, vol. 1, p. 58.

565 Alpers, pp. 277-278.

${ }^{566}$ KM Stories, p. 35. 
in the background: confinement, birth, growth, self-defence, flowering, harvest, death, and burial. The treatment of these processes has elements of satire as well as of the philosophical, psychological, mystical, and lyrical. These cyclic processes, ending in 'Prelude' with moments of exploration and decision, question whether the burial of the self (the author's and reader's as well as the characters') is a death or a potential for rebirth. This implied question is more explicit in observations in a letter of Mansfield's to Ottoline Morrell (c. 20 April 1919):

It has been a miracle to watch the roots \& bulbs buried by M. last October burst out of their little graves and put on beauty [...] Oh this spring [...] Each year I think - this year I shall not feel it so keenly - but I feel it more - Why are human beings the only ones who do not put forth fresh buds - exquisite flowers and leaves [...] We have all been wintry far too long $-{ }^{567}$

Further, this implied question can be extended to physical death, to Beryl's questioning whether an "unsubstantial”, "real” self might exist "for ever" ("Shall I ever be that Beryl for ever?”). Answers to this question are suggested in Linda's dreamed night journey on the aloe, which combines implications of physical death (recalling the duck scene) with movement into new beginnings (recalling Lottie’s and Kezia’s actual night journey with its mythic overtones).

In summary, 'Prelude' is a densely multi-layered text that both sets up and subverts the conventional status quo of child subordinate to adult, servant subject to master, and female vulnerable to male. The story's initial emphasis on conventional hierarchy is variously subverted by comic, tragic, and satiric role reversals, associations with plant and animal imagery, and the use of central symbols to which all the characters are connected. The text's shape comes from its gradual unfolding into wider dimensions: the first six sections suggest the individual characters' development, connecting them all to the aloe at the end of section VI; sections VII to IX have a more satirical emphasis, culminating in the killing and processing of the duck as representing social exploitation, with which again all the characters are associated; and the two final sections are more mystical in tone, suggesting the characters' isolated personal responses to their glimpses of their predicament. Throughout, the characters' assumptions about their conventional roles are contrasted with implications of the unexpected. The text becomes a vehicle for ambiguity, questioning, surprise, and playful transformation. Opposites meet: overtones of birth and death are merged in the ${ }^{567}$ KM Letters (O and S), vol. 2, p. 313. 
same events, the experience of the duck and of the aloe interrelate, and images of reversal suggest that anything at any time can become its opposite. In the final analysis, all becomes part of the "one mysterious movement" that permeates the end of the text, and imagery of the buried self is part of that movement in its potential for death or rebirth. 


\section{Conclusion}

'Juliet', ‘Brave Love', and 'Prelude’ demonstrate Katherine Mansfield’s constant acceptance of the challenge of the "gulf to be bridged" to "reveal a little of the mystery of life”. Each of these works sets up orthodox oppositions, such as between conventional and unconventional ('Juliet'), naïve and cynical ('Brave Love’), and master and servant ('Prelude'); each work then subverts those oppositions through irony. Instead of the standard values associated with such institutions as family, the art world, church, and marriage, these values are quietly mocked, and other values and realities emerge. All the characters, on whichever side of the oppositional divide they belong, are linked to symbols of vulnerability (such as the rose in 'Juliet' and the duck in 'Prelude') and of the biological, social, and psychological forces that shape them (such as the wheel image in 'Juliet' and 'Brave Love', more subtly suggested in the “one mysterious movement” in 'Prelude'). Within this multidimensional context, myths are used, from explicitly in 'Juliet' to sparingly in 'Prelude', to suggest fragmented, contrasting potentialities of identity; in 'Prelude', the presence of hidden aspects of the self (with overtones ranging from the satirical to the spiritual) is revealed through association. The questioning of identity and experience, linked to those wider dimensions through symbol, myth, and association, further leads by implication to questioning the nature of existence itself, for example, as Beryl's intuitions of her "real self” and "false self” oppose overtones of spiritual self and socially shaped consumer product.

This reading of Mansfield's work, then, agrees with commentaries that emphasise the binary or fluid in her work and recognise its combination of impressionist and expressionist techniques. Mansfield’s approach, both multidimensional and questioning, was to break down and reunite. This modernist method was to take nothing on trust but, conversely, to question and qualify every level by provocative, surprising interconnections between them. As Mansfield wrote to Murry (8 November 1920): “Always examine both sides. In my house both sides is buttered."568

${ }^{568}$ KM Letters (O and S), vol. 4, p. 103. 


\section{Bibliography}

\section{Primary sources: Katherine Mansfield}

The Aloe, ed. and intr. Vincent O’Sullivan. London: Virago Press, 1985.

The Collected Letters of Katherine Mansfield, vol. 1-4, ed. Vincent O'Sullivan and Margaret Scott. Oxford: Clarendon Press, 1984, 1987, 1993, and 1996 respectively.

The Complete Stories of Katherine Mansfield. Auckland: Golden Press, 1974.

'In the Botanical Gardens', by Julian Mark (pseud.). Native Companion (2 December 1907). Rpt.in Katherine Mansfield: New Zealand Stories, selected by Vincent O’Sullivan. Oxford University Press New Zealand, 1997.

The Katherine Mansfield Notebooks, vol.1 and 2, ed. Margaret Scott. Canterbury: Lincoln University Press; and Wellington: Daphne Brasell Associates, 1997.

The Letters of Katherine Mansfield, vol.1 and 2, ed. J. Middleton Murry. London: Constable, 1928.

'The Meaning of Rhythm', by John Middleton Murry and Katherine Mansfield. Rhythm, no. 5 (1912). Rpt. in Hanson, The Critical Works of Katherine Mansfield, p. 22.

Novels and Novelists by Katherine Mansfield, ed. J. Middleton Murry. London: Constable, 1930.

\section{Primary sources: Other}

Bergson, Henri. Time and Free Will, 1889; first English version 1910. Quoted in Katherine Mansfield: A Literary Life by Angela Smith. Hampshire, UK, and New York: Palgrave, 2000, p. 10.

Eliot, T.S. (1923). Quoted in The Oxford Illustrated History of English Literature, ed. Pat Rogers. Oxford and New York: Oxford University Press, 1987.

Homer. The Odyssey of Homer, trans. William Cowper.. London: Dent; first published in this edition 1910.

Ovid. Metamorphoses, trans. A.D. Melville. Oxford: Oxford University Press, 1986.

Pater, Walter. 'Coleridge’s Writings'. Westminster Review, 1866. Rpt. in Walter Pater: Essays on Literature and Art, ed. Jennifer Uglow. London: Dent; Totowa, N.J.: Rowman and Littlefield, 1973. 
Pater, Walter. The Renaissance, Studies in Art and Poetry. Fontana, 1961. Quoted in 'The Magnetic Chain: Notes and Approaches to K.M.' by Vincent O’Sullivan. Landfall, vol. 29 no. 2 (June 1975). Rpt.in The Critical Response to Katherine Mansfield, ed. Jan Pilditch. Westport, Connecticut; London: Greenwood Press, 1996.

Shelley, Percy Bysshe. 'The Triumph of Life'. In The Selected Poetry and Prose of

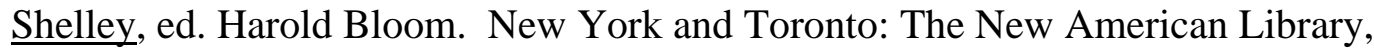
1966.

Tennyson, Alfred. 'The Lotos-Eaters'. In Poems of Tennyson. London: Thomas Nelson and Sons, n.d.

Tolstoy, Leo. War and Peace, trans. Constance Garnett. Publisher and date not shown.

Wagner, Richard. Parsifal: Ein Bühnenweihefestspiel: Vollständiger Klavierauszug. Mainz: B. Schott’s Söhne, 1902.

Wagner, Richard. Parsifal [libretto], trans. Peter Basset. Included with the Parsifal programme for 17 and 19 March 2006, Michael Fowler Centre, Wellington.

Wilde, Oscar. The Picture of Dorian Gray. In The Works of Oscar Wilde, ed. Dr Timothy Gaynor. Twickenham, UK: Senate, 1997.

\section{Criticism and biography: Katherine Mansfield}

Alpers, Antony. The Life of Katherine Mansfield. London: Jonathan Cape, 1980

Arvidson, Ken. 'Katherine Mansfield and a Way of Seeing'. Katherine Mansfield Stories and Pictures. Department of English, The University of Waikato Occasional Paper no. 2, 2003, pp. 7-14.

Baldeshwiler, Eileen. 'Katherine Mansfield's Theory of Fiction'. Studies in Short Fiction, vol.7 no.3 (Summer 1970), pp. 421-432.

Bateson, F.W. and Shahevitch, B. 'Katherine Mansfield’s “The Fly”: A Critical Exercise'. Essays in Criticism, vol. 12 (January 1962), pp. 39-53. Rpt. in The Critical Response to Katherine Mansfield, ed. Jan Pilditch. Westport, Connecticut; London: Greenwood Press, 1996, p. 86.

Daly, Saralyn. Katherine Mansfield. New York: Twayne Publishers, 1965.

Dowling, David. 'Aunt Beryl’s Doll’s House’. Landfall, vol. 34 no. 2 (June 1980), pp. 148-158.

Else, Anne. 'The Insipid Doctrine: Joining the Resistance in New Zealand'. Women's Studies Journal (December 1988), pp. 41-47. 
Fullbrook, Kate. Katherine Mansfield. Bloomington and Indianapolis: Indiana University Press, 1986.

Fullbrook, Kate. 'Katherine Mansfield: Subjection and Authority'. The Fine Instrument: Essays on Katherine Mansfield, ed. Paulette Michel and Michel Dupuis. Sydney: Dangeroo Press, 1989, pp. 61-50.

Gurr, Andrew. 'Katherine Mansfield: The Question of Perspectives in Commonwealth Literature’. Kunapipi, vol. 6 no. 2 (1984). Rpt.in The Critical Response to Katherine Mansfield, ed. Jan Pilditch. Westport, Connecticut; London: Greenwood Press, 1996.

Hankin, Cherry. 'Fantasy and the Sense of an Ending in the Work of Katherine Mansfield’. Modern Fiction Studies, vol. 24 no. 3 (autumn 1978), p. 465-474.

Hankin, Cherry A. Katherine Mansfield and Her Confessional Stories. London: Macmillan, 1983.

Hanson, Clare, ed. The Critical Writings of Katherine Mansfield. New York: St Martin’s Press, 1987.

Hanson, Clare and Gurr, Andrew. Katherine Mansfield. London: Macmillan, 1981.

Kaplan, Sydney Janet. Katherine Mansfield and the Origins of Modernist Fiction. Ithaca and London: Cornell University Press, 1991.

Magalaner, Marvin. The Fiction of Katherine Mansfield. Carbondale and Edwardsville: Southern Illinois University Press; Feffer and Simons, 1971.

Murray, Heather. 'Linda Burnell, Housewife: A Life Sentence for Cowardice?'. Women’s Studies Journal, vol. 4 no 2 (1988), pp. 32-39.

New, W.H. Reading Mansfield and Metaphors of Form. Montreal: McGill-Queen's University Press, 1999.

O’Sullivan, Vincent. 'The Magnetic Chain: Notes and Approaches to K.M.' . Landfall, vol. 29 no. 2 (June 1975). Rpt. in The Critical Response to Katherine Mansfield, ed. Jan Pilditch. Westport, Connecticut; London: Greenwood Press, 1996.

O’Sullivan, Vincent. 'What We Mostly Don't Say about Katherine Mansfield'. Katherine Mansfield's Men: Perspectives from the 2004 Katherine Mansfield Birthplace Lecture Series, ed. Charles Ferrall and Jane Stafford. Wellington: Katherine Mansfield Birthplace Society in association with Steele Roberts Publishers, 2004.

Sandley, Sara. 'Prelude’ entry. In The Oxford Companion to New Zealand Literature, ed. Roger Robinson and Nelson Wattie. Melbourne: Oxford University Press, 1998. 
Scott, Margaret. 'The Unpublished Manuscripts of Katherine Mansfield'. The Turnbull Library Record (March 1970), p. 5.

Simon, Irène. 'Irony in the Short Stories of Katherine Mansfield'. The Fine Instrument: Essays on Katherine Mansfield, ed. Paulette Michel and Michel Dupuis. Sydney: Dangeroo Press, 1989, pp. 97-105.

Smith, Angela. Katherine Mansfield: A Literary Life. Hampshire, UK, and New York: Palgrave, 2000.

Smith, Angela. 'Katherine Mansfield and Rhythm'. Journal of New Zealand Literature, vol. 21 (2003), pp. 102-121.

Smith, Angela. Katherine Mansfield and Virginia Woolf: A Public of Two. Oxford: Clarendon Press, 1999.

Stafford, Jane and Williams, Mark. Maoriland: New Zealand Literature 1872-1914. Wellington: Victoria University Press, 2006.

Stead, C.K. 'Katherine Mansfield: The Art of the "Fiction”'. The New Review, London (September 1977). Rpt. in In the Glass Case by C.K. Stead. Auckland: Auckland University Press and Oxford University Press, 1981.

Tomalin, Claire. Katherine Mansfield: A Secret Life. London: Viking, 1987.

Van Gunsteren, Julia. Katherine Mansfield and Literary Impressionism.

Amsterdam-Atlanta: Editions Rodopi, 1991.

Wattie, Nelson. 'Katherine Mansfield as a Noble Savage: The Cry against

Corruption'. In The Fine Instrument: Essays on Katherine Mansfield, ed. Paulette Michel and Michel Dupuis. Sydney: Dangeroo Press, 1989, pp. 149-156.

Woods, Joanna. Katerina. Auckland: Penguin, 2001.

Zinman, Toby. “ “The Snail under the Leaf”: Katherine Mansfield’s Ironic Vision’ [Dissertation]. USA: Temple University, 1973.

\section{General reference}

Abrams, M.H. A Glossary of Literary Terms, $7^{\text {th }}$ ed. Cornell University: Harcourt Brace, 1999.

Collins English Dictionary, $6^{\text {th }}$ ed. Glasgow: HarperCollins, 2003.

Concise Oxford Dictionary, $8^{\text {th }}$ ed. Oxford: Clarendon Press, 1990.

Gibson, Robert. 'Guardians of the Grail: Keeping Parsifal for Bayreuth'. Parsifal programme for 17 and 19 March 2006, Michael Fowler Centre, Wellington. 
Harewood, the Earl of, ed. and rev. Kobbé's Complete Opera Book London: Putnam, 1969.

Hollander, John. The Figure of Echo: A Mode of Allusion in Milton and After. University of California Press, 1981.

Hollington, Michael. 'Svevo, Joyce and Modernist Time'. Modernism 1890-1930, ed. Malcolm Bradbury and James McFarlane. The Harvester Press, 1978.

Kuna, Franz. 'The Janus-faced Novel: Conrad, Musil, Kafka, Mann’. Modernism 1890-1930, ed. Malcolm Bradbury and James McFarlane. The Harvester Press, 1978.

The Macmillan Family Encyclopedia, vol. 9. UK: Macmillan London, 1983.

Rogers, Pat, ed. The Oxford Illustrated History of English Literature. Oxford and New York: Oxford University Press, 1987

Stangroom, Jeremy and Garvey, James. The Great Philosophers. London: Arcturus Publishing, 2005.

Strong, Roy. The Spirit of Britain: A Narrative History of the Arts. London: Pimlico, 2000. 


\section{Appendices:}

Texts of 'In the Botanical Gardens', 'Juliet', and 'Brave Love' 


\section{Appendix 1: Text of 'In the Botanical Gardens'}

Source: Katherine Mansfield: New Zealand Stories, selected by Vincent O’Sullivan. Auckland: Oxford University Press New Zealand, 1997, pp. 18-20. Reproduced by permission of Oxford University Press. 


\section{In the Botanical Gardens}

They are such a subtle combination of the artificial and the natural - that is, partly, the secret of their charm.

From the entrance gate down the broad central walk, with the orthodox banality of carpet bedding on either side, stroll men and women and children - a great many children, who call to each other lustily, and jump up and down on the green wooden seats. They seem as meaningless, as lacking in individuality, as the little figures in an impressionist landscape.

Above the carpet bedding, on one hand, there is a green hedge, and above the hedge a long row of cabbage trees. I stare up at them, and suddenly the green hedge is a stave, and the cabbage trees, now high, now low, have become an arrangement of notes - a curious, pattering, native melody.

In the enclosure the spring flowers are almost too beautiful - a great stretch of foam-like cowslips. As I bend over them, the air is heavy and sweet with their scent, like hay and new milk and 
the kisses of children, and, further on, a sunlit wonder of chiming daffodils.

Before me two great rhododendron bushes. Against the dark, broad leaves the blossoms rise, flame-like, tremulous in the still air, and the pearl rose loving-cup of a magnolia hangs delicately on the grey bough.

Everywhere there are clusters of china blue pansies, a mist of forget-me-nots, a tangle of anemones. Strange that these anemones - scarlet, and amethyst, and purple - vibrant with colour, always appear to me a trifle dangerous, sinister, seductive, but poisonous.

And, leaving the enclosure, I pass a little gully, filled with tree ferns, and lit with pale virgin lamps of arum lilies.

I turn from the smooth swept paths, and climb up a steep track, where the knotted tree roots have seared a rude pattern in the yellow clay. And suddenly, it disappears - all the pretty, carefully tended surface of gravel and sward and blossom, and there is bush, silent and splendid. On the green moss, on the brown earth, a wide splashing of yellow sunlight. And everywhere that strange indefinable scent. As I breathe it, it seems to absorb, to become part of me - and I am old with the age of centuries, strong with the strength of savagery.

Somewhere I hear the soft rhythmic flowing of water, and I follow the path down and down until 1 come to a little stream idly, dreamily floating past. I fling myself down, and put my hands in the water. An inexplicable, persistent feeling seizes me that I must become one with it all. Remembrance has gone this is the Lotus Land - the green trees stir languorously, sleepily - there is the silver sound of a bird's call. Bending down, I drink a little of the water, Oh! is it magic? Shall I, looking intently, see vague forms lurking in the shadow staring at me malevolently, wildly, the thief of their birthright? Shall I, down the hillside, through the bush, ever in the shadow, see a great 
company moving towards me, their faces averted, wreathed with green garlands, passing, passing, following the little stream in silence until it is sucked into the wide sea...

There is a sudden, restless movement, a pressure of the trees - they sway against one another - it is like the sound of weeping ...

I pass down the central walk towards the entrance gates. The men and women and children are crowding the pathway, looking reverently, admiringly, at the carpet bedding, spelling aloud the Latin names of the flowers.

Here is laughter and movement and bright sunlight — but behind me - is it near, or miles and miles away? - the bush lies hidden in the shadow. 


\section{Appendix 2: Text of 'Juliet'}

Source: The Katherine Mansfield Notebooks, vol. 1, edited by Margaret Scott.

Canterbury: Lincoln University Press; and Wellington: Daphne Brasell Associates Ltd, 1997, pp. 48-69. Reproduced by permission of Dunmore Press (current publishers of the notebooks). 


\section{Notebook 1}

$[\text { Notebook I, qMS-1242] }]^{3.3}$

Chap I. October i4th

Rough [Notes]

Chap II. The birth of the flame

Chap III. The God

Chap IV

I8.V. 06.

Chapter I

October I4th.

Juliet sat in front of the mirror brushing her hair. Her face was thoughtful and her hands trembled perceptibly. Suddenly she bent forward and stared at her own reflexion. Her hair, parted in the middle, fell in long straight masses of pale gold to her waist. Her forehead was high \& square \& very white, while there was an unusual fullness over her brows. Her eyes were a peculiar colour, almost approaching green, her nose very straight $\&$ fine, and her mouth was full of sensitive curves - the underlip decidedly too full for regular beauty. Her face was square in outline and her skin very white. The impression which

\footnotetext{
${ }^{33 .} \mathrm{KM}$ 's first piece of sustained (albeit autobiographical) fiction, usually referred to as 'Juliet', occurs in this notebook, interspersed throughout with other material. To facilitate reading, the scattered pieces of 'Juliet' have here been assembled, not into a continuous narrative but into the sequence of parts in the order in which they were written.

KM was still at school in London, aged 17, when she began 'Juliet', and eight or nine months later she abandoned it. It could fairly be described as 'Notes towards a novel' as it consists of a series of discomnected episodes (one assumes that the situations which appealed to her most were the ones she tackled first), and these are not written in the order that the chronology of the final narrative would demand. Nevertheless it is possible to piece together the main outline of a story, and to perceive the weaving in of themes which were to remain central to her for the rest of her life.

My own first transcription of 'Juliet' was published in Thie Tumbll Library Record in March 1970, and was, alas, imperfect. More time and work have enabled me to improve it.

In the original transcription I tagged each section with a letter of the alphabet for ease of reference. These tags are repeated here because they have now become part of the critical record. The pages of the notebook were numbered by Murry and the page numbers of each 'Juliet' piece are here supplied to convey an ider of the size of the notebook and the distribution of the 'Juliet' pieces within it.

There are inconsistencies and obscurities in the text which have, of course, been retained. $\mathrm{Mr}$ Wilberforce becomes Mr Night; David was once nearly written as Caesar (the name by which KM called Tom Trowell to whom she had long been romantically attached); Vere becomes Pearl; Juliet is at first the second of four children and later seems to be the youngest of three.
} 
it caused was not by any means strictly beautiful. When in repose it conveyed an idea of extreme thoughtfulness - her mouth drooped slightly at the corners, her eyes were shadowed, but her expression was magnetic, her personality charged with vitality. She looked a dreamer, but her dreams were big with life - -

But Juliet noticed none of these characteristics. Since her very early days she had cultivated the habit of conversing very intimately with the Mirror face. Her childhood had been lonely, the dream-face her only confidante. She was the second in a family of four. The eldest girl, Margaret, was now seventeen, Juliet was fourteen, and then two babies, Mary \& Henry, aged seven \& six respectively. The Mother was a slight pale little woman. She had been delicate \& ailing before her marriage and she never could forget it. Margaret \& she looked after the babies - and Mr Wilberforce, ${ }^{34}$ a tall grey-bearded man with prominent blue eyes, large ungainly hands, and inclining to stoutness. He was a general merchant, director of several companies, chairman of several societies, thoroughly commonplace \& commercial. The greater part of his life had been spent in New Zealand \& all the children had been born there.

Juliet was the odd man out of the family - the ugly duckling. She had lived in a world of her own, created her own people, read anything \& everything which came to hand, was possessed with a violent temper, and completely lacked placidity. She was dominated by her moods which swept through her and in number were legion. She had been, as yet, utterly idle at school, drifted through her classes, picked up a quantity of heterogeneous knowledge - and all the pleading \& protestations of her teachers could not induce her to learn that which did not appeal to her. She criticised everybody and everything with which she came into contact, \& wrapped herself in a fierce white reserve. 'I have four passions' she once wrote in an old diary 'Nature, people, Mystery, and - the fourth no man can number.' Of late she had quarrelled frequently with the entire family, through pure lack of anything definite to occupy her thoughts. She had no defined paths ahead, no goal to reach \& she felt compelled to vent her energy upon somebody, and that somebody was her family.

The large bedroom where she sat looked very dim and dark. There was a small fire in the grate and a big rocking chair before it, but these were the two positive luxuries which the room boasted of. Pictures were conspicuous by their absence, and all these little familiar things which make the sum total of so many girls'bedrooms found no place here. A long unvarnished bookshelf was nailed above the bed \& a most miscellaneous collection of volumes found a resting place there. A glass of red roses stood on the dressing table and all her party clothes were carefully laid out on a chair. She dressed very deliberately in her white muslin frock - open at the neck \& showing her full round throat - and tied her broad silk sash. Her hair hung in two great braids, unadorned

\footnotetext{
${ }^{34} \mathrm{KM}$ 's friend on whom the hero of this story, David, was based was Thomas Wilberforce Trowell. This exemplifies again her tendency to choose uames she was already fomiliar with-or variations of them-for her not quite fictional characters.
} 


\section{0/ Notebook 1}

with combs or ribbon. She put up her hands \& patted the smooth heavy folds. Juliet's hands were as distinctive as any part of her. They were large, and exquisitely modelled. The fingers were not very long, and blunted at the tops, but no amount of work could change their beauty. She gesticulated a great deal \& had a habit of sitting always nursing one knee, her fingers interlocked.

Before leaving her room she crossed over to the window. Outside a great pine tree was outlined against the night sky, and the sea, stretching far in the distance, called to her - 'Juliet, Juliet." $\mathrm{O}$ night'she cried, leaning far out and turning her face up to the stars, 'O adorable night.' - - -

Then she picked up her long cloak and ran lightly downstairs. In the hall her Mother and Father were waiting, $\mathrm{Mr}$ Wilberforce wrapping up his throat in a great silk handkerchief with all that care \& precision so common to perfectly healthy men who imagine they wrestle with weak constitutions.

'We shall drop you at Mrs Cecil's on the way, Juliet' said her Mother, carefully drawing on her long evening gloves, 'and then at ten o'clock you can call for us at Mrs Black's. And we shall come back together. You can wait in the hall if we're not ready. It's only a musical party.' The girl replied, and the three walked out of the house, down the broad stone steps, and into the long moonlit road. In the presence of so many stars and so many trees Juliet utterly forgot all the petty grievances of the day. She walked along beside her parents and 'let it all sink in' as she expressed.

'Do be careful of your clothes, child' the Mother said, as MrWilberforce held the gate open for her, 'and don't be late.' Then they left her. In front of her was the brilliantly lighted house. Sounds of merriment came to her, uproarious laughter, shrieks of excitement. And for two hours she played as vigorously as the rest of them, inwardly rebelling and very satisfied when the clock pointed to five minutes to ten. The 'party'stood and watched her from the door - cried to her not to be afraid, to remember 'Ghosts in the Garden', but she laughed \& holding her coat tightly round her, ran the whole length of the way.

On the doorstep of Mrs Black's she paused to recover breath, and a faint, a very faint wave of Music was wafted to her. The drawing room seemed extraordinarily bright after the night outside. She was a little confused at first. The maid had said that they were all at supper, and she was to wait there. She went over to the table \& bent over a bowl of flowers, but a sound of a chair being pushed back in the corner caused her to look up, startled. A boy of very much her own age was watching her curiously. He stood beside a great lamp \& the light fell full on his face and his profusion of red-brown hair. Very pale he was with a dreaming cxquisite face \& a striking suggestion of confidence \& Power in every feature. Juliet felt a great wave of colour spread over her face and neck. They stood staring into each other's eyes. Then he walked up to the table where she stood, a faint smile playing round his lips. "If you are fond of flowers there are roses just outside the window' he said, 'and you can reach out your hands \& touch them. The scent is perfect. Come \& see.'

Side by side they crossed over to the wide opened window, \& both leant 
out. O, the late roses below them - thousands there seemed to Juliet.

She touched one, then another with her hands - they were all wet with dew. 'Heavy with tears'she said, looking up at the boy. He nodded appreciatively. 'Will you tell me your name?' Juliet - and yours?' David. I am a musician \& have been playing tonight - a 'cellist you know. I am going to Europe next year.'I too, but not for music - to complete my education, you know.'Do you want to go away?' YYes - and no. I long for fresh experiences, new places, but I shall miss the things that I love here.'Do you like nights Juliet'. His face was transfigured. 'I feel like a chrysalis in the daytime, compared to my feelings after sunset. For instance I should never have met you as I have if I hadn't just come in from the stars. They make me all music. Sometimes I think that if I could be alone long enough I should hear the Music of the Spheres. Think of what would burst from those thousands of golden throats.' I have heard so little music' said Juliet sadly. 'There are so few opportunities. And a 'cello - I have never heard a 'cello.' David's face was full of compassion \& yet joy. 'Then I shall be the first to show you what can be' he said. He stooped down \& broke a great flower off the branches \& gave it to her. She fastened it in her dress, and then the sound of the guests returning from the supper room put an end to their conversation. Soon after, they left. Juliet purposely avoided saying 'goodnight' to David. She felt as though she could not, but she was conscious of his eyes watching her as she left the room.

The walk home was silent. Margaret was awaiting their arrival and immediately began telling Mrs Wilberforce how 'used up the babies seemed. 'Henry has certainly a nasty little cough'she said, '\& Mary looked so pasty.' 'Well, we shall all leave town in a couple of days'Mrs Wilberforce said. 'Tomorrow that young boy is coming here to play, and Father has asked a number of men.'Juliet bade them goodnight \& fled to her own room. Her heart was beating furiously - she could hardly repress a feeling of the most intense joy that bade her cry out. She sat on the side of her bed staring at the darkness, her breath coming quickly. Sleep was impossible. The whole world had changed \& he was coming again tomorrow night, \& she should hear him play. She crept into bed and lay still, thinking. A curious sensation stole over her - as though she was drifting in a great fiery sea of thoughts, \& every thought was sweet.

When she pulled up the blind next morning the trees outside were being tossed to and fro, and the sea lashed into fury by a wild Southerly gale. Juliet shuddered. The wind always hurt her, unsettled her. It was a Saturday, so there was no thought of school. She wandered about all the morning, and in the afternoon put on her reefer coat \& tam-o'-shanter and went for a walk up the hills that spread like a great wall behind the little town. The wind blew fiercer than ever. She held on to bushes and strong tufts of grass, and climbed rapidly, rejoicing in the strength that it required. Down in a hollow where the gorse spread like a thick green mantle she paused to recover breath. The utter loneliness of it filled her with pleasure. She stood perfectly still, letting the wind blow cold \& strong in her face and loosen her hair. The sky was dull 


\section{2/ Notebook I}

\& grey, and vague thoughts swept through her - of the Future, of her leaving this little island \& going so far away, of all that she knew and loved, all that she wished to be. 'O I wish I was a poet' she cried, spreading out her arms. 'I wish I could interpret this atmosphere, this influence.'She found a little bird fluttering near in a bush, its wing broken by the storm - and held it close to her, overcome with a feeling of tenderness. 'I am so strong'she said, 'and the strong are never hurt. It is always the weak who are pained.' (Foolish child! April 1908.)

She walked home more slowly. Now that the excitement of climbing had left her she felt tired \& depressed. Clouds of dust whirled up the road - dry particles of sand stung her face. She longed for the evening to come, yet almost dreaded it.

When tea was over Juliet went back to her room, tried to read \& failed, and walked up and down - nine steps one way - nine steps another. The feeling soothed her. She heard the front door bell ring and knew that the guests had arrived, but she stayed there till Margaret sought her out \& brought her down with great indignation. The room seemed full of people, but Juliet was not shy. She held her head a little higher than usual \& an expression of almost indifference came into her face. David stood by the piano unfastening his music case. She shook hands with him and shot him a keen quick glance of recognition. Then she curled herself up in a corner of the sofa \& watched the people with amusement \& interest. She liked to listen to little pieces of conversation, create her idea of their lives.

There was the usual amount of very second rate singing concerning Swallows and "Had I Known". Margaret played several nondescript pieces on the piano - \& at last David's turn came. Juliet watched him with great pleasure \& curiosity. A bright spot came into her cheeks, her eyes wide opened - but when he drew his bow across the strings her whole soul woke and lived for the first time in her life. She became utterly absorbed in the music. The room faded, the people faded. She saw only his sensitive inspired face, felt only the rapture that held her fast, that clung to her and hid her in its folds, as impenetrable and pure as the mists from the sea - - -

Suddenly the music ceased, the tears poured down her face \& she came back to reality - - - She put her handkerchief to her eyes and when she looked round became aware of the amused glances of the company, and heard the steady, almost prophetic sounding voice of David's Father: "That child is a born musician."

The rest of the evening passed she knew not how. Something had come to life in Juliet's soul \& it shone in her transfigured face. For that night she was brilliantly beautiful - not with the beauty of a child, but the charm of a woman seemed to emanate from her. David was conscious of this, conscious too that he had never played before as he was playing. They avoided each other strangely, but $\mathrm{Mr}$ Wilberforce praised the boy and said 'You might come \& give my little daughter a few lessons, \& see if she has any talent.' She never forgot their leave-taking. The wind was furious, and she stood on 
the verandah and saw David turn round \& smile at her before he passed out of sight. $[(\mathrm{A}) \mathrm{PP} 3-23]^{3.3}$

'Know anything about these times that we have had - but whenever you come to see us in London - I - I shall feel so utterly different.'David looked at her. 'Yet now you would not have it otherwise, Juliet. A secret is a glorious thing.' She gave him both her hands. 'Goodbye, my friend'she said. 'I promise to write to you - often - often.' He suddenly caught his breath. 'You would not kiss me . . Juliet', he said hoarsely. But she shook her head, and a moment later the beach was deserted \& the sea crept up \& washed away their footmarks from that place. $\quad[(\mathrm{B}) \mathrm{P} 23]$

\section{Chapter III}

It was the close of a dark day - London was shrouded in fog. The streets were wet and the long line of lampposts shone like dim ghosts of themselves. A four-wheeler, laden with luggage, stopped at the door of an eminently respectable house. $\quad[(c)$ P24]

Juliet stumbled up the stairs - somehow she reached the door and let herself in and locked it again. Then she groped her way into the sitting room. The fire had gone out - she did not notice it. The wind had blown over the roses on the table, \& they lay in a crushed heap on the carpet. The room was flooded in the cold light of the moon. She stood gazing at it all, then a long shudder went through her and she fell heavily on to the floor. She was conscious as she lay there. Why didn't I strike my head on the fender, she thought - I'm not hurt a bit. I shall have to get up again and then it will be day. She shivered incessantly from head to foot, and a wheel began to go round \& round \& round in her head. 'Down \& down \& down \& down \& down'said the wheel as it whirred, 'down \& down \& down \& down \& down.' Then it assumed gigantic proportions, and she clung to it and it dragged her round. Round \& round \& round \& round \& round in a great pit of darkness - and she fell.

It was certainly a very successful dinner party. Caesar was never so gay, so

$[(D) P 29-30]$ irresponsible, so full of boyish spirits. He stood on his chair with a glass of the I/ 3 claret in his hand \& made interminable speeches till Rudolph seized him by the coat \& dragged hin to earth. And then the four of them sat round the fire and smoked, \& laughed, \& finally grew serious. Rudolph seized his fiddle \& played the Serenade Melancholique, and then they left Caesar. Their feelings overcame them - "it was the claret" said Rudolph sighing heavily. "Gott sei dank" said Caesar. [ $\quad$ [ 30$]$

\footnotetext{
${ }^{35}$ The pages of the notebook were numbered by Murry and the page numbers of each 'Juliet' piece are here supplied to convey an idea of the size of the notebook and the distribution of these pieces within it. The other interspersed material, written at the same time, is presented here after 'Juliet', with page numbers indicating its placement in the notebook. I have also repeated here the alphabetical identification I gave to each of the sections in the original transcription because they have since been used in other people's critical discussions.
} 


\section{4/ Notebook 1}

The Shudder of the Trees.

$<$ Juliet and Diana>

I an a lover of London Town.

"Keys with the caretaker." The street looked cheap. Juliet looked at it with tired eyes - dingy, forlorn, certainly this would be very near her standard. She found the caretaker $\&$ he conducted her up five flights of stairs. "Certainly not here" thought Juliet with an uneasy feeling that her legs might consider themselves as separate from her body \& refuse to advance. And then "Nonsense, perhaps it must be here." There was a passage and leading from it three rooms - one large 'living' room and a small bedroom and a minute kitchen. She looked round, noticed that the window had wide low ledges, that in the recess at either side of the fireplace there [was] a wide washed [white-washed?] cupboard doing up with a button. "O - I like it" she said, nodding seriously - and the rent was decidedly within her limit. [(E) PS2]

Das Geheimnis.

It happened when I was young but unconscious of Youth.

And dark crept into the room. Juliet, lying back in her chair, saw the sky a pale soft yellow, watched the steady outpouring of smoke from the chimneys opposite. A faint breath, like a sigh from the passing day, stirred the window curtains and blew on to her face. Sounds floated up to her - . - intensely individual yet blending into the great Chorale of Twilight. An extraordinary weakness stole over her. 'She was dying softly softly'like the day. Her arms hung straight on either side of her chair, her hair fell back among the cushions, her lips slightly parted.

- - The horror of the long white day. She could not endure another. Here in this twilight, shaking off her great chains of Commerce, London shone, mystical, dreamlike. And Juliet too felt like a dream. She was floating, floating in the veil-like pale sky. Yesterday had never been, today had never been, tomorrow was not. This struggle for bread, this starvation of Art. How could she expect to keep art with her in the ugliness of her rooms, in the sordidness of her surroundings. Listlessly she raised her head \& looked round. But the room was full of cool emptiness - nothing was apparent, everything suggestive and full of charm. "You will stay with me a little longer, while I can offer you this Magic hour" whispered -

The sky changed. Only a narrow strip of the pale yellow remained \& above a thin blue on which the darkness of night sky was partially hidden. Patches of rich golden light shone in the houses. She felt her fatigue, her doubt, her regrets, slip off from her tired heart. "O - O", she said, "How weak I am. How I ought to be full of strength, \& rejoicing all the day. Relations at the other end of the world who have, thank Heaven, cast me off and my wish fulfilled. I'm alone in the heart of London, working \& living - . -"Then another thought came - she shook her head \& frowned, but a great wave of bitter [...] memories broke over her \& drowned all else - . - Where was he now. What was he doing. How did he live - married, single, rich, poor nothing was known. She shook from head to foot with pain and anger with 
herself. Were those five years to haunt her always - would she never be strong enough to stand absolutely alone. Should the first thought at waking always be "Who knows" \& the last thought at night "Perhaps tomorrow." She moved restlessly. "I say I am independent - I am utterly dependent. I say I am masculine - no-one could be more feminine. I say I am complete - I am hopelessly incomplete." Try as she would she knew that it was hopeless to attempt to change. "I must just put up with it" she said aloud.

Suddenly she listened. Someone was mounting the stairs quickly, lightly. She glanced at the clock, it was just half past eight. The steps came nearer. Outside her door they stopped. There was a momentary pause, then a knock, sharp, imperative. She sprang to her feet, and something within her seemed to spring to birth \& laugh. She sprang to her feet, lit a small jet of gas, then opened the door wide. In the passage a man leaned against the wall, the intense black of his coat against the white wall, the broad sweep of his hat. Then he put out his hand. Terror seized her. "David" she whispered - she could scarcely articulate. Her mouth was parched. She leaned against the door for support. "David". "I have found you now" he said, seizing both her hands $<\&$ dragging her into the room \& over to the light, his pale face full of a great peace. $>$ (Nonsense) $\quad[(\mathrm{F}) \mathrm{pP} 53-56]$

The Man.

When she reached the long tree-lined avenue, the rain had ceased and great splashes of sunlight lay across the road. As she neared the house she stopped \& repeated the Dorian Grey. Her heart was beating almost unbearably. She pressed her hand against her hot face. "This is gloriously unconventional" said Juliet, "but I wish I was less frightened."

Walter opened the door. "Ha - you've come at last" he said, his voice full of intense hospitality. "Come along into the smoking room - second door to the right." She pushed aside the heavy purple portière. The room was full of gloom but vivid yellow curtains hung straight $\&$ fine before the three windows. Tall wrought-iron candle-sticks stood in the corners - the dead whiteness of the candles suddenly brought back a memory of Saint Gudule at dusk and Juliet caught her breath. There were prints of beautiful women on the walls, \& the graceful figure of a girl holding a <great> shell in her exquisite arms stood on a table. There was a long low couch upholstered in dull purple, and quaint low chairs in the same colour. The room was full of the odour of chrysanthemums. ${ }^{36}$ The blossoms were arranged in high glasses on the mantel shelf - - -

"I am afraid" said Walter, closing the door and speaking slightly apologetically, "it's not very - . - "

"Please I like it" Juliet said, smiling at him \& pulling off her long gloves. He pulled up a great armchair for her, then seating him[self] opposite so that

${ }^{36}$ This passage from 'Come along into the smoking room' to the odour of chrysanthemums appenred, slightly reworked, in a story called 'The Education of Audrey' published in The Evening Post. Wellington, 13 January 1909 . 


\section{6/ Notebook 1}

he might watch her face - "Now tell me all about yourself." How revoltingly hearty his voice sounds, thought Juliet - - - She paused, then "There's not very much to tell."

"How about those complications."

"O they're quite gone, thank you. I - I took your advice."

"That's fine. That's fine. I knew you would my dear girl, I always said you had the grit in you."

$\mathrm{O}$, the fearful paternal conceit.

"I - - I finally made up my mind to put an end to them. It was hard, you know - but - I have wished to thank you ever since."

"O that's alright, and as you grow older \& see more cases of that very thing, you will realise better than you can now how right I was. Drifting is so dangerous."

"Yes - - you made me feel that."

"And don't you feel more comfortable in yourself. Of course you miss something."

"Yes I really do - intensely."

"Yes, naturally, but now the leaving [tearing?] part of the whole business is over, aren't you really very pleased?"

"Yes, I think I am." She sat very still \& suddenly smiled slightly. "You have changed" said Walter. His voice had curiously altered. [(G) pP63-65]

"We've told Father all about it, Juliet" ${ }^{37}$ said Margaret. "And Father's fearfully angry" Mary added. Juliet slipped the Byron down in the front of her sailor blouse. She had no definite idea of what she had been reading but her head was full of strange unreasonable impulses. She was feeling slightly sorry for her absence of self control in that it incurred a long interview with her Father, and in all probability some degrading issue - no jam for a week, or to go to bed at seven o'clock until she apologised. She walked slowly to the house, up the broad stone steps, into the wide hall, and knocked at the morning room door. $[(\mathrm{H})]$

At two o'clock in the afternoon Juliet had thrown a heavy book at her eldest sister Margaret, and a bottle of ink at her elder sister Mary. At six in the evening she was summoned to the morning room to explain these offences. After her two wholly successful acts of violence she had retired to a sloping lawn at the extreme end of the garden where she lay down comfortably \& read Don Juan - - -

Margaret \& Mary, still smarting from the shock to their sensitive little systems,

${ }^{37} \mathrm{On}$ the page preceding this passage KM has listed chapter headings and names of characters in the story. The chapter headings are: 'i. Ruming away. B. night-meeting. ii. Sea chapter. iii. London. iv. College Influence. v. Vere, vi. Parents. vii. Project. viii. Fulfilment. ix. Truth \& Illness. x. Marriage. xi, Vere \& T. xii. Death.'

The characters listed on this page who actually appear in the story are: Juliet Night, David Méjin, 'Margaret +', 'Mary +', Pearl Saffron. Those who make no appenrance are: 'Mrs Dale mother-in-law to', Mr Dale, Mr Philip Dale, Mr Donald. Crossed out are: Kathie Schonfeld, Mark \& David, Dr Cayton. 
had rather rejoiced in the search for her, and more especially in the knowledge that $\mathrm{Mr}$ Night was pacing up \& down, up and down. They were both virtuous enough to take a keen enjoyment in the punishment of others. [(I) P72] "Juliet - Juliet please sit still. You walked round \& round this room till my pen is describing a hopeless \& idiotic circle. I must get this off tonight, and I can't if you will be so restless."

There was a note of intense annoyance in Vere's voice. She looked up from the sheets of foolscap arranged in neat piles before her. The afternoon had closed in - Pearl ${ }^{38}$ was writing by candlclight. Juliet had drawn down the blinds. The rain in the street hurt her. She had arranged all the odd books in a neat line on the mantelpiece. She had twice pulled the tablecloth straight, and then flung herself in a chair, tried to read \& failed, tried to write \& torn up the paper, sighed, tossed her hair out of her eyes, \& finally started walking up \& down the room, swiftly, quietly - - - She had a headache, felt tired, nervous - and longed to burst out crying.

For days the rain had been falling steadily monotonously over London until it seemed to be suffocating her, beating into her brain. She had slept very little at night and her face [was a] little worn and set. AtVere's remark she stopped walking and said "I - I beg your pardon. I did not quite realise what I was doing." she said.

Vere laid down her pen \& pushed back her chair. "Got a mood?"

"Yes" said Juliet, "it's the very Devil. While it lasts I think it is going to be eternal \& I'm contemplating suicide."

"It's sure to be something physical. Why don't you sleep better Juliet. Are you - you're not ... repenting?" 3 "

"Good Heavens, no. The truth is, my dear girl, well I hardly like to own it to myself even, you understand. Bernard Shaw would be gratified."

"You feel sexual."

"Horribly. And in need of a physical shock or violence - perhaps a good smacking would be beneficial."

"Don't laugh so much at yourself, Juliet. I'm sorry dear - you look wretchedly ill."

"It's the candlelight. Also I am in need of exercise. I shall go out, I think, for a walk, despite the fact that I shall become physically, mentally \& psychically damped." "Do, dear."

"I feel a need of a big grey sky, and a long line of lights. Also a confused noise of traffic and the sense of many people - you know?"

"Yes, I understand, but I loathe the rain. It makes me irritable. I hate the slashing effect that it has - and it makes me "fussy'."

Juliet went over to Vere \& suddenly kissed her.

\footnotetext{
${ }^{38}$ Originally written as 'Vere' and subsequently altered to 'Pearl'.

${ }^{399}$ In my first transcription of 'Juliet', published in The Turnhull Library Record, I misread this word as 'expecting' and so missed the significance of KM's awareness of the possibility of regret at having cut oneself off from one's family, long before she herself experienced this.
} 


\section{8/ Notebook 1}

"Think my dear" she said, one hand on Vere's shoulder, "if it had not happened I should be in the middle of Summer. Saturday night - helping the family to entertain a few friends to dinner perhaps, or hearing Father first snore \& then yawn and finally tell me all he had for lunch, and all that everybody else had for lunch. The Evening would come to an end at ten o'clock with lemon \& soda which Mother would refuse to drink because quotation of course - it was so 'windy'. O Lord! Instead - I earn at least f., I.O.O a week, I live with the best friend that anyone could wish for in London and I am free! Voilà, by enumerating all these excellent fors \& againsts I feel better, and inclined to kiss you again."

"Our friendship is unique" said Vere, folding her arms \& staring at the light. "Nothing could separate us, Juliet. All the comforts of matrimony with none of its encumbrances, hein?"

"My word yes! As it is we are both individuals. We both ask from the other personal privacy, \& we can be silent for hours when the desire seizes us."

"Think of a man always with you. A woman cannot be wholly natural with a man - there is always a feeling that she must take care that she doesn't let him go."

"A perpetual strain."

"Also I should inevitably want to fly very high if I was certain that my wings were clipped."

"Ugh" said Juliet, going over to the wardrobe \& reaching for her coat \& hat, "I loathe the very principle of matrimony. It must end in failure, \& it is death to a woman's personality. She must drop the theme \& begin to start playing the accompaniment. For me there is no attraction."

Vere suddenly laughed. "I was thinking of your past affaire de coeur with David Méjin," she said.

"Please don't" cried Juliet. "To think of it makes me feel overwhelmingly sick. When I think how he filled, swayed my whole life, how I worshipped him only I did. How jealous I was of him! I kept the very envelopes of his letters for years, \& he - to say the least - raised his hat \& passed on.." "What would you do if you met him now?"

"Broadly speaking - do as I had been done by. I should simply bow."

"I don't know that I would do that ...."

"Well", she drew on her gloves, "I shall take the plunge dear, \& bring you back a brown loaf for supper. There is something aesthetic in the substance of a brown loaf."

Once out in the streets Juliet walked very fast, her head bent. She was thinking, thinking. How absurd everything was. How small she was. She walked along Holborn and into Oxford Street. The restaurants were full of light, and the sound of laughter seemed to be in the air. $<$ A curious helplessness took possession of her - an inability to speak or to stop walking.

Half way down Oxford Street she suddenly heard a hoarse cry in the street. There had been an accident. In an instant there had sprung up scores of people who were all hurrying forward. Juliet ran with them. As she neared the place she heard "'E's done for, poor feller. 'E caught 'im fair on the leg." 
"Hit 'is head too - 'e was in the hansom." $>\quad[(\mathrm{J})$ PP73-77]

(Let us linger no longer over these things. They are really very touching.)

David \& Pearl were married as soon as I [ie they] reasonably could be after Juliet's death, and a year \& a half later, when a girl child was born, they both decided she should be christened after 'poor Juliet'. Pearl gave up smoking cigarettes \& published a little volume which she called "Mother Thought" ... somehow the title does not seem intensely original. Also, when they realised the possibility of another extension to their family they bought a nice little house near Cricklewood, and David achieved no small measure of success with his gardening.

Rudolf did not return to England after his tour in Italy but went further afield to Spain \& Portugal. So he knew nothing of Juliet's death until a long time had passed - - MrThring, the porter at No 65, gave him a most full, true \& particular account. In the Autumn season he brought out a very charming little morceau "Souvenir de Juliet" It create quite a quiver[?] at the London concerts. $<$ So much so that he rearranged it for violoncello to be played with muted strings. $>$ It was reported on highest authority that the original MS was stained with tears - . . -

(Let us linger no longer over these things. They are really very touching.)

The Triumph of Rudolph.

Juliet dressed with great care that afternoon. She had on a thin white muslin frock with a square-cut yolk [sic] \& short sleeves tied with ribbons. She brushed out her long hair, \& then braided it round her head. Pearl, sitting huddled upon the lounge, smoking \& read[ing] Zola's Paris, laughed. "How do I look" said Juliet anxiously, slipping on a long coat \& then taking a rapid survey of her two possible hats. "Entirely irresistable my dear. Wear the black one - it's so ingenuous-looking" said Pearl - - -

"I want to make a really good impression. I've been looking hideous lately I know - because I've been worried about the play - but now that it's actually finished I shall grow a big conceit in myself. Do you know, Pearl" she added, with mock gravity, "I never realised that Summer was here until today." "Well run along or you'll be late dear. Kiss me first. Somehow I feel as though I should like to take opium this afternoon."

Juliet put her arms around her ... "Dearest \& best" she said, \& blushed on saying it, "I should like to be staying with you but duty calls - you understand." "Of course ... of course - by the way I shan't be in until after eleven - I'm going to a Promenade." "Very well, I shall be waiting for you perhaps crushed to death by the criticism of David." "Who knows" said Pearl, shrugging her shoulders.

On her way to Canton Mansions Juliet bought 2 pink roses \& tucked them into her belt. Also she felt that the sunshine had got into her brain - - - 


\section{0/ Notebook 1}

It was sparkling \& golden \& enchanting like champagne. She hugged her roll of MS as she mounted the stairs \& then knocked quickly. Her heart was beating $\&$ she felt that her cheeks were crimson. She stood waiting for several seconds \& then knocked again. Rudolf opened the door \& swept her an extravagant bow.

"Bon jour, Mdlle" he cried in his mocking voice.

"Is David in" asked Juliet.

"He received your telegram Mdlle \& a thousand apologies but asks me to amuse you for just thirty minutes as he has so important an engagement. It is just thirty minutes, Mdlle, and I am sorry for you - - -"

Juliet felt intensely annoyed. How could David have done such a thing, knowing as he did that she hated the very sight of Rudolf. Also for some inexplicable reason she felt afraid of him - he was so utterly at his ease, so lightly contemptuous, so recklessly impertinent. She stood by the table in the middle of the room, frowning slightly, \& Rudolf leaned against the mantelpiece - and laughed. Then she turned to him.

"It is very kind of you to offer to entertain me. If I can sit here \& read through my work I shall be quite happy, thank you" she said. On no account must she allow Rudolf to guess that her heart was beating violently, that she had to hold her hands under her long cloak so that he could not see how they were trembling. She drew up a chair \& sat down.

"Dieu, Dieu, how hot it is" called Rudolf. "That coat is impossible Mdlle. Here - let me take it. Stand up - Voilà ... \& your hat. Is it not heavy - il faut souffrir - no, that cannot apply to you."

Juliet stood up \& allowed him to take her coat \& hat. She could not trust herself to speak to him. He is a fiend, she thought, a perfect fiend. How can he look at me like that. She did not know exactly what to do, and then suddenly thought - how idiotic I am. Really I am rude. Perhaps he is trying to be kind - \& fancy being afraid of anyone.

Perhaps if I really can talk to him alone for 30 minutes we shall understand each other in the future. Perhaps - yes $-I$ am sure that is why David has arranged this. She looked up \& smiled suddenly.

"Après tout, I shall talk" she said - "Do you think I am rude."

"Not at all - perhaps you, if I might venture to say it, do not disguise your feelings very well, Mdlle." Rudolf sat down opposite to her, \& leaning his elbows on the table watched her face - -

"Tenez" he said, "let us revive recollections. It is a charming thing that I love to do - - My favourite word in the whole language is 'Souvenir', Mdlle."

"The first time I saw you" Juliet answered severely, "I heard you whisper to David 'but she is a curiosity', and I never forgave you. It sounded as though I edited the Family Herald."

"No. no, you misunderstood me. I was interested. You were so different from anyone else \& you had known those tea coffee \& cocoa creatures that we have seen - \& also you did not like me. I saw it in your eyes."

"Did you expect me to. Did all the tea coffee \& cocoa creatures "cast down their golden crowns'straightway." 
"Ah, you do not know the life of the musician" said Rudolf, sighing deeply \& casting his eyes heavenward.

Juliet laughed \& said "Don't be affected. I don't like you, to tell you the truth - you're forward, at least you appear so, and I feel that you despise me. I hate that! I like you professionally, not personally."

She suddenly jumped up \& looked at herself in the little glass that hung over the mantelpiece.

"How my hair looks" she said, giving it a little pat all over. "Is it alright now?" she appealed to him.

"Adorable" said Rudolf, "\& the little white dress \& the two pink roses \& the little black shoes - \& the ribbon."

"Please stop" said Juliet. She was afraid again. Why would he not understand when she was joking \& when she was serious? It is his voice that is so abominable, she thought. His voice \& his eyes.

Rudolf tossed back his hair \& opened the piano. He began playing the overture to Tannhäuser, heavily \& magnificently.

"Ah Mdlle" he said, raising his voice, "you do not understand me. We can never be friends, I fear. There are too many obstacles. You are too conventional."

"I am - " interrupted Juliet.

"Yes you are more conventional than a child from a convent school. Also you never allow your feelings to run away with you - you have no core of sensation."

"I haven't" cried Juliet.

"No you haven't. Also you are a bad actress \& I am a wonderful reader of charactère." He had come to the end of the Pilgrim's Song \& began playing it again. His tone was almost brutal. "It is the heritage from your parents" he said. "You have fought against it, but voilà there it is, always conquering you. You are afraid of everything \& you suspect everybody. Dieu! how afraid you are."

"I am not" said Juliet, shaking her head - but the colour rushed into her cheeks.

He started the Venus Motif. "Here am I" he said "reckless, a lover of all that you have desired to love, because my mother was a Danseuse and my father an artist. Also there was no marriage - -" He ceased speaking but the music filled the room. He repeated the wonderfulVenus call. "Ah, it is divine" he said. "That is whar you should be, Juliet. What - how am I for Tannhäuser."

The music was flooding Juliet's soul now. The room faded. She heard her hot heavy impassioned voice above the storm of emotion - - -

"Stop, stop" she said, feeling as though some spell was being cast over her. She shook from head to foot with anger \& horror.

"Listen again" said Rudolf. It was a Chopin nocturne this time. "Live this life, Juliet. Did Chopin fear to satisfy the cravings of his nature, his natural desires. No, that is how [?] he is so great. Why do you push away just that which you need, because of convention. Why do you dwarf your nature, spoil your life. 


\section{2/ Notebook 1}

If you were a man you would be a teetotaller \& then a Revivalist. You are the most beautiful girl I have ever seen - no don't interrupt - I shall never speak like this again. I shall go away tonight. But you are, Juliet. It is not regular beauty - it is fascination - some fearful attraction when you choose to appear fascinating. Yet you are a little tinnide, and you know nothing - absolutely nothing. You are blind, \& far worse, you are deaf to all that is most worth living for."

Juliet sprang to her feet. "I shall not listen to you" she said, the tears starting to her eyes. "I shall go home now, this instant. How dare you speak like this Rudolf - how dare you. I am suffocated. Where did you put my coat \& hat!" Her eyes were blazing.

Rudolf suddenly sprang up from the music stool \& caught her by the arm. "It is not for nothing that I have such a tone" he said, speaking hoarsely. His face was mad with passion, white with desire.

"Leave me alone" said Juliet. She raised her eyes to his face, \& his expression caused her to suddenly cease struggling \& look up at him dumbly, her lips parted, terror in her eyes.

"You adorable creature" whispered Rudolf, his face close to hers. "You adorable creature - you shall not go now - -" She felt the room sway \& heave. She felt that she was going to faint. "Rudolf, Rudolf" she said, \& Rudolf's answer was "at last." [(L) PP78-86]

It was eleven o'clock when David ${ }^{40}$ entered the sitting room. He found Rudolf <clad in his pyjamas $>$ at the piano composing. "Be quiet mon ami" he cried, "listen a moment." David stood still. Rudolf played madly, wildly, fiercely - the Music that was coursing through his brain seemed to intoxicate him. "It is my masterpiece" he shouted, closing the piano \& falling on to David's neck.

"It was my masterpiece."

"What the Devil has come over you" cried David, bringing out of his pocket the program of the evening Promenade. "I'm still full of Wagner, \& behold I find he is here incarnate in my room."

"Yes, yes" said Rudolf, pulling David's handkerchief out of his pocket and applying it to his eyes. "I am Wagner - I'm at the top of the whole world, \& it is rather strange. Rejoice with me" he said, <running his hands through his hair.>

David lighted a cigarette \& stood with his hands clasped behind his back. "Are you drunk?" he said thoughtfully. "Oui, oui, drunk I am - with the wine of Life, mon ami - . -"

"Well go and be drunk somewhere else. I've got an infernal headache \& I want to smoke in peace."

"Ah excuse, mon cher" said Rudolf, laying his strong hand on David's arm.

"I shall be like a sucking baby[?] if you will be kind. Where have you been."

"I took Pearl to the Promenade."

"Bon Dieu me garde!" ejaculated Rudolf. David turned to him sharply.

\footnotetext{
4h'David' was written after 'Caes' had been firnly scored out with three strokes.
} 
"Why not?" he said, "why not? What do you mean. We talked about Juliet the whole time."

"Did you take Pearl home."

"Yes. I didn't stay - Juliet was asleep on the sofa - - - \& it was so late.

Anyone been here?"

"Not a soul" cried Rudolf airily, waving his hands to express boundless emptiness \& vast solitude - - -

"I suppose the rose leaves floated through the window" said David, stooping to pick up some pink petals.

"They were once a buttonhole" said Rudolf, "but it died \& I threw it out of the window."

"That is a lie" was the answer. His voice was very quiet. "Juliet's been here,

I know it. The remains of these blossoms[?] she was wearing ten minutes ago.

Besides, I knew it the moment I came in." Rudolf grew suddenly confused \& silent. Then he shrugged his shoulders." "It is true" he said. "She left you this MS. I can't think why I invented that sweet little tale - . ." "Ah thanks" said David, taking the roll of paper from the table. "I can't think why you did either - you two fight like cat \& dog." Rudolf frowned. "She hates me" he said. "She is impudent. This afternoon she insulted me. She is the only woman who has ever insulted me." "So you were ashamed to tell" queried David. "I wish that she hated me. It is an abominable position - - - I feel as though I ought to love her - to me she is an angel, she has always been an angel - but I do not. She is too like me. I understand her too well. We are both too moody, we both feel too much the same about everything. That is what I feel and so she does not attract me - do you understand?" "Perfectly - but Pearl?"4z David paused, then "Need I tell you? I cannot help myself. I am madly in love with Pearl. ${ }^{+3}$ She is so inexplicable, so reckless, so unlike me - I cannot understand her. I cannot think how she feels about me. It attracts me - - \& she challenges me. The Lord only knows how all this will end" he added.

And the winter came again. The rooms in Carbury Avenue began to look cold $\&$ cheerless.

"Don't for Heaven's sake start fires" said Pearl, "they stop me working strenuously - also the price of coal." So they kept the screen in front of the fireplace and resolutely refused to think of the long sweet drowsy evenings that might have been theirs. Juliet was sleeping badly again.

"I dream so much" she told Pearl. "Every night terrible dreams - all about when I was little \& about people I'd quite forgotten - \& then I wake \& try not to sleep again - it is so heart-breaking." She had become intensely pale $\&$ the shadows were always under her eyes now. "You ought to feel more, \& think less" Pearl would answer. "Write something stupendous, create a colossal scheme \& then it will cure you." "Ideas keep coming to me - it is not for lack

\footnotetext{
${ }^{41}$ This last phrase begins $\mathrm{p} 88 \mathrm{a}$ at the top of which $\mathrm{KM}$ has written 'Trowell'.

${ }^{42}$ See note 38 .

${ }^{4.3}$ See note 38 .
} 


\section{4/ Notebook 1}

of ideas that I have not written, but somehow that last play seemed to have stolen so much of my vitality."

They were both sitting in the half dark, talking thus, when Pearl suddenly looked at the clock \& cried "Good Heavens - I must fly - I'm due for a sitting at half past six \& it's nearly that now."

She went. Juliet listened to the sound of her steps going down down down, then along the corridor \& then lost. She folded her hands in front of her \& suddenly the tears poured down her face - - -

I wonder why I am crying, she thought - am I sad - am I am I. She crept over to the lounge \& lay down, her head buried in the cushions. She was assailed with the most extraordinary thoughts. They seemed to be floating towards her, vast \& terrible. I feel as though I was on a great river, she thought, \& the rocks were all closing around me - coming towards me to sink me - and now \& again Rudolf's face came before her - the broad low brow, the great sweep of hair, the fire of the eyes, the eager curve of his mouth almost just a trifle mocking but also concerned, just a trifle concerned.

She saw the strong supple hands, hands such as Aubrey Beardsley would have given an Artist. It is Rudolf, \& Rudolf \& Rudolf she said to herself. Then suddenly a fierce thought sprang to birth in her brain - - - Did he ever think that there might be consequences to his act? Did he ever for one moment dream that Nature might cry to the world what was so hidden, so buried? Terror took possession of her. "O no, not that" she said, "never, never that. That would be diabolical \& the world isn't diabolical - at least it can't be. Nothing would exist if it was." But if - if - then if she were certain she ${ }^{4+}$

$[(\mathrm{N})$ ppgo-gIA $]$

"How you've changed"45 he said, half whispering. "Mightn't it have been better if you had just followed your destiny. For girls like Pearl it is of course different - she is made differently, Juliet, but - your guarded life. Perhaps by this time you would be - . -"

"Please be quiet" said Juliet. The tears were choking her now - the hopeless tragedy. $\mathrm{O}$, yes, he was a fool, this David - why did she love him?

"But am I not right?" he went on, almost tenderly. She shook her head.

"I have made my own bed - no, no I don't mean that. I adore this life, I worship it - it has been Heaven!" But she over acted her part. Suddenly he caught one of her hands.

"Listen" he said. "Listen. Go back, dear. We shall all help you, we have spoken so much of you lately. You are so changed - it is not right - you are wasting your life. And you have been dear \& sweet to me always. How we change, Juliet. When we first knew each other, both so young, so full of quaint romantic impossibilities - but those two children are dead now \& we are man \& woman - all is different. You made a mistake - for the sake of your old view, Juliet, try \& go back. We shall both help you - . - Pearl \& I - . -"

\footnotetext{
${ }^{44}$ The passage which once followed, whether one page or more, was torn out prior to the numbering of the remaining pages.

${ }^{45}$ This sentence is preceded by 'her fears', which followed from a page now torn out.
} 
Juliet looked up into [his] face. How very very heavy she had grown. She could hardly hold up her head now - - - It is quite extraordinary like a dead body, she thought. All the six undertakers couldn't lift her now. How curious - two Davids - how strange - two huge gigantic Davids - both of them thundering "Pearl \& I - - - "What colossal Davids. She must run away \& tell Grannie. She started to her feet - - - \& fell - - - [(o) pp92-93]

Day \& night the rain fell. The sky would never be light again, it seemed. The little bedroom was <full of bottles \& $>$ always dark but it did not matter - as Pearl told David, Juliet did not need light now. <They nursed her together now $>$

When the doctor had first come \& told Pearl how it was with Juliet the girl was dismayed \& horror stricken. She went into the sitting room where David was waiting. "David" she said "this is awful - I had not the slightest idea that Juliet - "

"What is the matter" he said.

"O our poor Juliet. She has been shockingly treated - you know - you understand?"

"I'll not believe you" said David.

"It is perfectly true. David she is going to die."

"I'll not believe you."

"It is true. Come in and see her - she cannot know - . -"

They went back to her room. The doctor left as they entered, promising to come again next morning. Also he would send a nurse immediately. Juliet lay straight \& still, her face twisted with horror They stood \& watched her. David suddenly stroked her hand - - -

"Rudolf" she cried piteously, pleadingly - \& then both of them knew.

Day \& night the rain fell \& at last one afternoon the end came. $<$ The nurse had gone out for a few moments. Pearl \& David stood by the bed.> Juliet came back painfully. She was groping the dark, trying to feel her way along. Out of the dark two voices came.

"It cannot be long now."

"But it is for the best. If she had lived what could have happened."

"I begin to believe there must be a merciful God."

"I, too."

She opened her eyes \& saw the two beside her.

"Ought I to join your hands \& say bless you" she whispered.

Suddenly she raised herself - "O - O I want to live" she screamed, but Death put his hand over her mouth. [(P) PP93A-95]

Juliet looked round her room curiously. So this was where she was to spend the next three years - three years. It did not look inviting. She noticed two texts ornamented with foxgloves \& robins - - - \& decided that they must come down. The three large windows looked out upon the Mews below - the houses built all round in a square. She wondered who would share this sanctum. Some English girl, stiff \& sporting, who would torture the walls with 


\section{6/ Notebook 1}

pictures of dogs \& keep a hockey stick in the corner. Heaven forbid, she thought. She sat down by the side of the bed \& pulled off her long gloves. How strange \& dim the light was.

She was alone in London - glotious thought. Three years of study before her. And then all Life to plunge into. The others were actually gone now. She was to meet total strangers. She could be just as she liked - they had never known her before. $\mathrm{O}$, what a comfort it was to know that every minute sent The Others further away from her! I suppose I am preposterously unnatural, she thought, \& smiled.

Then the porter brought in her two large boxes, and behind him Miss Mackay hovered \& told Juliet she must have everything unpacked before teatime - it was quite one of the old customs. Did the glory of England rest upon old customs? She rather fancied it did. When to start overcoats \& when to stop fires, hard boiled eggs for Sunday supper, and cold lunches. She knelt down on the floor and unstrapped her luggage. From the pocket of her suitcase she drew out David's picture \& looked at it seriously, then bent forward \& kissed it.

"Here we are, dear" she said aloud. "Boy of mine, I feel that life is beginning write now." 4 "

When the old custom had been sustained \& she had undressed she suddenly longed to write just a few lines of her impressions. So she slipped into her kimono \& drew out her notebook.

"If I could retain my solitude" she wrote, "I should be profoundly happy. The knowledge that sooner or later I shall be hampered with desirable acquaintances takes away much of the glamour. The great thing to do is to start as I mean to continue - never for one moment to be other than myself as I long to be, as I never yet have been except with David." She laid down her pen \& began braiding her hair in two thick braids. There was a knock at the door and immediately afterwards Miss Mackay entered with a tall thin girl beside her.

"My dear" the old lady said, "Juliet", positive Maternity in her tone, "this is your roommate, Pearl Saffron - new like yourself so I hope you will be friends." [(Q) PP95A-97A]

Because she was the youngest she expected the most. She had vague notions that it was always, would always be the third who was the favourite of the Gods. the fairy tales that she devoured voraciously during her childhood helped to stimulate the thought. [ [ R $\mathrm{P} 98]$

Juliet passed a sleepless night. ${ }^{47}$ She lay still in the darkness staring at the dim outline of the roofs outside the window, thinking, thinking. Each moment her brain seemed more awake. If I do once go back, she thought, all will be over. It is stagnation, desolation that stares [me] in the face. I shall be lonely. I shall be thousands of miles from all that I care for \& once I get there I can't come back. I can't do it. If they choose to behave like devils they must be treated as

\footnotetext{
${ }^{45} \mathrm{KM}$ probably meant 'right now' but the word is clearly 'write' as she has it.

${ }^{47}$ At the top of this page KM wrote and crossed out 'Ake Ake Aroha'.
} 
such. On one hand lay the mode bohème - alluring, knowledge-bringing, full of work and sensation, full of impulse, pulsating with the cry of Youth Youth Youth. Pearl with her pale eager face and smiling ripe mouth, crying to Juliet "Here I am - here we both are. Trust me dear, live with me. You and I to reach for things together, you and I to live and prove our new Philosophy."

On the other hand lay the Suitable Appropriate Existence. The days full of perpetual Society functions, the hours full of clothes discussions - the waste of life. The stifling atmosphere would kill me, she thought. The days - weeks months - years of it all. Her father, with his successful characteristic respectable face, crying "Now is the time. What have I got for my money. Come along deck yourself out, show the world that you are expensive. Now is the time for me to sit still and have my slippers brought for me. You are behaving badly. You must learn to realise that the silken cords of parental authority are very tight ropes indeed. I want no erratic spasmodic daughter. I demand a sane healthy-minded girl - <close the shutters upon your lopsided ambitions>. It is quite time for you to put up the shutters upon this period." In the darkness Juliet smiled at the last expression. It was so exactly like him an undeniable trade atmosphere.

Towards dawn she slipped out of bed, wrapped herself round in the quilt, and began pacing up and down. Her face was burning with excitement. It has been so easy to speak of taking the plunge when two years of student life lay definitely before me, but now that the moment has arrived, the water looked very cold. All their arguments passed sharply across her brain - a neat selection of platitudes, altruisms, aphorisms. Will they wear - will they hold good, she thought, and then cried "Yes, yes - I have the Key in my hands. Shall I unlock the door and get through \& then shut it again, bang it again with all the old Life outside - \& Pearl \& I alone at last."

She sat down at the table \& took up her pen, then wrote rapidly "Pearl I am coming. Understand I answer now for good \& for all. I don't know why I have hesitated so long. Ought I to be grateful to you for taking me - - - I don't think I am, dear, because I would do exactly the same if the circumstances were reversed. You realise that I want to find out what everything is worth - \& you too, my friend. What has held me back from coming has been I think principally the thought that we are not to be together for a week or a month or a year even, but for all times. It is rather immense \& requires consideration. So to bed. I am lonely. J."

When the seven o'clock dressing bell rang [Juliet] woke to the full consciousness of a nervous headache. She knew from experience that it was of no earthly use to attempt to do anything except succumb \& lie still. So she slipped into her kimono \& went along the stone passage to Miss Grimwood's bedroom. That lady on a seat before the glass tastefully decorated[?] her head with her three soft switches, \& when Juliet came in she enmeshed herself in a salmon pink fascinator ${ }^{48}$ with no small measure of confusion \& embarrassment. "I arn afraid I shall have to stay in bed all day" said Juliet. Then in answer to numerous significant inquiries \& nods - "No, nothing, thank you. Merely a

\footnotetext{
${ }^{48}$ A fascinator was a lace or crocheted head covering for women.
} 


\section{8/ Notebook 1}

headache. Meals - no thank you. Yes, tea perhaps, if I might have it very strong. If I can just lie still. $O$, no, quite unnecessary - I shall take some phenacetin. If I might be left alone. Overwork - $\mathrm{O}$, by no means. They are quite a common occurrence."

Then she went back to her room \& pulled down the blinds \& crept into bed.

The hours pulsed slowly on. After an immeasurable length of time she saw Pearl standing beside her, tall \& grave in her black frock with a white feather boa round her throat.

"This is good" said Juliet sitting up with her hands clasped round her knees. "What is the time."

"Just four" Pearl smiled. "How do you feel."

"Rather damnable."

"Can you talk."

"My dear yes. I feel better for the sight of you. Give me that pink carnation you're wearing, \& sit on the bed here."

"I got your letter this afternoon, Juliet, by the two o'clock post, \& came straightway to your room, my dear."

They suddenly held each other's hand.

"To the devil with my relations" said Juliet.

"To the Devil with our Past Life" said Pearl. "All the way here I have been quoting Oscar's 'Relations are a very tedious set of people'. You know, it has been like a charm." ${ }^{\prime 4} \quad[($ s) PPIO6A-IIOA $]$

\section{Chapter I}

Behind the house the hills rose in a great sweep of melancholy grandeur. Before it lay the wide restless ocean. Juliet dreamed. She stood at the foot of a great bush-covered hill. It towered above her, and she had a curious sensation that it was alive and filled with antagonism towards her. On the very crown of the hill the sunlight lay, sheer golden. Juliet began to slowly climb. At first she followed a narrow sheep track for a short time, then lost sight of it \& clung to brambles and trees, sometimes finding a firm foothold, sometimes stumbling or sinking ankle deep into a mass of rotting leaves. This will take me a terribly long time, she thought. Then a hand grasped hers and someone pulled her swiftly and carefully over the fallen tree trunks, across the narrow streams. She was out of the bush now. A long stretch of short grass was before her. The unseen guide disappeared.

Juliet resolutely walked on. The hill seemed to increase to an enormous size, the patch of sunlight at the top grew more intense, the air became full of sound. She was conscious of many people near her, of voices raised in anger or alarm. I must try \& not look to the right or to the left, she thought, but only at the sunlight. Then she entered the bush again. The trees crowded round her, menacing, terrible. The fern trees waved their long green branches. They are like arms, thought Juliet. She walked faster, then began running, and suddenly tripped over a long thick supplejack ${ }^{50}$ and fell.

\footnotetext{
${ }^{49}$ After this pencil written section KM subsequently wrote, in ink, 'I can wait no longer'.

${ }^{50}$ Supplejack: Ripogonum scandens, a mame for various climbing and twining shrubs with tough pliable stems found in tropical and (as here) subtropical forests.
} 
For some inexplicable reason she began to cry - loudly, like a little child - and made no attempt to get up. Then someone caught her by the shoulders and put her on her feet again and brushed the earth and twigs from her dress. She walked on, sobbing a little, and full of despair. On and on, until a river rushed across her path. Now it is all over; she thought. I shall have to stay on this side. She sat down on a flat rock and began throwing little pebbles into the water, and each pebble as it fell floated on the top of the water until there was a great bridge of the pebbles, and she walked across to the other side quite safely.

Now she found a road - a dusty much used road - and suddenly a great fog swept over all the land. Again she heard the sound of many voices, and suddenly in the darkness someone struck her in the face. A feeling of intolerable shame seized her - she ran faster \& faster, and when the fog drew away it reminded her of the man at the circus. When he lifted the handkerchief off the flowerpot something beautiful was there. She was very near the end of the journey. Just a few more steps. But how heavy she had become! She could hardly walk. She was too tired to look for the sunlight - she only saw the dust on the road. So few more steps and then she could rest and feel that all the trouble was behind her. Her steps grew slower \& slower - she seented hardly to be moving.

Suddenly a gust of cold air blew on to her face. She looked up. She stood on the summit of the mountain. There was no sunlight, no sound, nothing. ${ }^{51}$ Only the fierce wind that beat upon her face she could hardly stand against. She stretched her arms to cling to something - and fell.

$[(\mathrm{T}) \operatorname{PPIII}-\mathrm{II} 4]$ 


\section{Appendix 3: Text of 'Brave Love’}

Source: The Katherine Mansfield Notebooks, vol. 2, edited by Margaret Scott. Canterbury: Lincoln University Press; and Wellington: Daphne Brasell Associates Ltd, 1997, pp. 35-55. Reproduced by permission of Dunmore Press (current publishers of the notebooks). 


\section{Unbound Papers}

$[\mathrm{NL}]$

\section{BRAVE LOVE ${ }^{3 *}$}

I.

As Mitka turned into Wyndham Square he heard a beautiful clock strike ten. The sound seemed to come from far away, from high up in the air. Mitka stopped to listen and to look up and about him. It was a warm, still night. The sky was studded with big stars and moonlight lay on the white houses and on the trees and little lawns of the square. Some of the houses had pink and white awnings spread over the balconies. The windows of all of them were filled with boxes of flowering plants, and through the open, lighted windows there came the sound of voices and laughter. Under the warm, white light the place looked strangely gay and lovely, but not quite real. It was like a place in a dream with a dream's aloofness and security in its own unreality. But then, thought Mitka walking on in the steps of his sharp shadow, the land is always like a dream to me. I shall long all my life to live on the land and while I am longing my life will pass in little ships and big ships...

As he came to number " 34 " he heard the sound of a piano and then Mildred West's voice floated to him. "It is all in vain - I implore thee." Ah, thought Mitka, she is singing to my brother. My brother is there - my darling

${ }^{38}$ 'Brave Love' is, strictly, outside the scope of this edition in that it is a complete story and it has been published. However, its history puts it in a special category. KM refers to it in a diary entry for 12 January tors where she says, 'Actually finished the story Brave Love and I don't know what to think of it even now. Read it to Jack who was also puzzled. Violent headache but rather happy.' Murry's footnote to this is, 'Of this story only the opening pages survive.' In fact the story was in Ida Baker's possession and when she sold it to a dealer he allowed her to keep a racher primitive photocopy of it. She gave this to me in 1971 and my transcription of it was published in Landfall, the New Zealand Literary Quarterly, in March 1972. That version-full of gaps and hesitancies - was picked up and republished, once in Germany (in German translation), once in Japan, and once in New Zealand where a reprine by Golden Press of Constable's Collected Stories tacked this one on to the end. The Oxford University Press The Stories of Katherine Mansficld: Defuitive Edition omits 'Brave Love' on the grounds that it is 'a tedious, confusing story never published by $\mathrm{KM}^{\prime}$.

The manuscript of the story eventually came to light in the Newberry Library where I was able to work on it and produce a more complete and accurate transcription than that published in Landfall in 1972. It can hardly be denied that the story is, on the surface, tedious and confusing, but it nevertheless has its own importance and should be studied. It would seem, then, that this, the better of the only two transcriptions of this story so far, should find a place in this edition. 


\section{6/ Unbound Papers}

Paddy! And he ran up the steps and gave the bell a pull that sent the German waiter rushing up from the dirty bowels of the house. Before Mitka had time to ask for his brother he heard Mildred's voice from the drawing room landing. "Who is there? Hans, who is it?" Mitka ran into the hall past the German waiter and shouted gaily, "It is I, Mitka."

"Mitka!" Mildred sounded very pleased. She came rustling down the stairs. "Really Mitka!" and into the hall. "Where have you come from?" She put her bare scented arms round his neck and kissed him and then held him away from her. "Let me look at you." Which meant at the same time "You may look at me, I am as lovely as ever." She wore a black dress and no ornaments except a pair of black pearl ear rings and a black rose dropping from her pale coloured hair. Her red lips and her beautiful painted eyes smiled at Mitka and he recognised the perfume that always clung about his brother the perfume like sweet dry wood. "Heavens, child, how brown you are! You are brown as a nut," said Mildred. She put her hand under his chin and tilted his face. "Grown a moustache, too. But I can't quite believe in it, Mitka. You look as young as ever."

He crinkled up his eyes. "Ah, you are going to push fun at me again," he said. "But I do not mind now. Since I leave here - for three years nobody is pulling my leg. I am quite forgetting how it feels."

"Come up to the drawing room," she said, laughing at him. "You speak worse English than ever. Come up to the drawing room. Paddy is there.

He'll be amazed at seeing you."

Mitka hesitated. "Couldn't I see him in some more private spot first," he suggested. But Mildred was firm. "No, you're not to be let off. We'd love to see you kiss Paddy. There is no one to be afraid of. Come along," and she took his hand and ran upstairs with him crying "Paddy, Paddy, guess who's here? Look who I've brought you."

For the moment Mitka forgot everything but his beautiful tall brother, all black and white, moving across the room to him. Tears started to his eyes. He ran and embraced Paddy and squeezed his arms.

"Why didn't you let me know, little one," said Paddy, almost as touched as Mitka. "Ah," he said, "I wanted to be a surprise for you. If I come back so suddenly it's as though I'm never quite gone."

"Listen to him." Mildred put her arm round his shoulder and pinched his ear. "Now you must be a little gentleman and say 'Good evening' to Mother and be introduced to your audience."

The drawing room was just as he had remembered it - all pink and white, with lamp shades like swollen roses and dozens of photographs in silver frames. Old Mrs Farmer, Mildred's mother, sat in her accustomed corner, with a ravel of wool and needles on her lap and just as before the little table beside her holding the parrot's cage, covered in a red and white check cloth.

She looked withered and trembling as he bent over her tiny yellow hand.

"Well now!" she quavered. "Well, well, well! I know you, young man, I know you," and peeped up slyly at him out of her puzzled eyes. "Miss Valerie Brandon," and Mitka bowed to a tall girl who stood at the grand 
piano, playing chords with the soft pedal down. She was wrapped in a gauze scarf and her neck and hair were steeped in candlelight. "Colonel Foster" an old man at the fire place, his feet towards the empty grate, and his plump, purplish hands, folded over his round stomach. "And these are my two boys." Mildred pointed, mocking, to two very dark young men playing cards in a corner. They grinned at Mitka, shuffled their feet, half rose, then subsided. "That's all over." Mildred gave an affected sigh, put her hand in Paddy's waistcoat pocket and took out his cigarette case. "Sit down on the sofa and hold Paddy's hand." She stood by the tall lamp looking down at them and each time she blew the smoke from her lips she lifted her head and seemed to offer to them her milky throat and breast.

"First thing of all," said Mitka, watching her in his naive admiring way, "I must deeply apologise for my clothes. But you know, being so seldom on land I have not got an evening dress. I know - it's a shocking confession."

"We'll forgive you," laughed Mildred. "It's a very nice blue serge dress, anyhow. Where have you come from? How long are you staying?"

"I came from Alexandria," he said, "and I am staying five days. Then I go to Marseilles, and," he shrugged, "Alexandria again. Back and forward, you know, all the time." "And have you had any wonderful adventures?" teased Mildred.

"Oh, no," said Mitka simply. "It's very quiet at sea, you know."

He rubbed his hands together. "Very quiet indeed." In the little pause they heard the soft muffled chords from the piano and the sound of the parrot walking over the roof of his cage.

"Stay with us, won't you," said Paddy. "Stay the five days here. There's an extra bed in my room that you can have."

"What! May I really - Oh, Paddy how sweet of you." Mitka longed to embrace him again. He wondered if Paddy had really changed or if it was only the people and the English room that made him feel so far away and so foreign.

"I'll lend you a nightdress for tonight," said Mildred. A snigger came from the dark young men in the corner and the hop-hop-hop of the ivory cribbage pegs. But nobody paid any attention. The Colonel was asleep, his baggy chin settled in his collar, Mrs Farmer's little eyes flew from Mildred to the brothers and back to Mildred, her face screwed tight in the effort to hear what they were saying, and Valerie Brandon sat down on the piano stool and began to play as softly as ever - she was all wrapped up in a gold net of quivering candle light.

"Oh," said Mitka, "how glad I am to be here. How beautiful it is.

How full of peace." He smiled at Mildred \& Paddy. "You're easily satisfied, my son," said she and made a little grimace.

"He's young," shrilled Mrs Farmer, suddenly. "Let him be, Mildred. He'll learn soon enough. He's young." Her lace cap trembled to her talking and she clicked open a large black fan and beat the air with it. "Dear me, Mother," drawled Mildred. "We are a-going it tonight, aren't we?" Mitka saw Paddy frown and heard him whisper, "Let her alone, Mildred." "Well, she's got no 


\section{8/ Unbound Papers}

right to interfere." Mildred shrugged her shoulders as Mrs Farmer gathered up and burst out again. "You wait, young man," she said. "You just wait a bit before you're so pleased with the outside of the glass." Mitka felt very uncomfortable. What a fool I am, he thought. My silly happiness always makes a scene. Now Paddy will be cross with me. I know he will.

But Paddy, as if he read Mitka's thoughts and wanted to reassure him, put his hand on Mitka's knee and said kindly, "So here's my little brother again." Mildred leaned back in her chair and smoked with half shut eyes. "Oh, Val," she drawled, "do stop that melancholy stuff. You're melting all my bones, darling. Do stop." Mitka looked over at the piano. The girl stopped playing. She folded herself in her white gauze scarf and wheeled round on the piano stool, facing them. "Very well," she said, "I'll stop. I've been crying myself for the last half hour." As she spoke she smiled faintly, her head a little on one side. She looked very slim and young perched on the little stool. She had black hair and long grey eyes. "I wonder," she said, still mocking, "if the parrot's asleep." She slipped off the stool with a little rustle of silk and went over to the cage and raised the cloth. "Polly - Polly -" she called and the parrot answered, copying her low voice. "Polly, Polly."

"Valerie, don't. He'll pull you to pieces," protested Mildred. But the girl opened the cage and put her hand in and drew it out with the red and grey parrot on her finger. Crouching back on her heels she held the bird up in her hand and stroked it and raised its wings. "Does he hate his silly old cage," she said, "and does the silly old light make him blink?" The parrot walked up her arm on to her shoulder and flapped its wings. "There, I told you so. He'll ruin your scarf," said Mildred. "No, he won't," saidValerie Brandon, "and I rather like the feeling of his sharp old claws in my shoulder. It amuses me," she added slowly and slowly turned and smiled at Mitka, who sat quite still watching the curious girl. "Would you like to nurse the pretty parrot?" she asked.

"Oh, Val, don't be a little fool."

"Who'd like to dandle our pretty Poll?" and she laughed and bit her under lip. "Oh, shut up," said Mildred. But Valerie did not take her eyes off Mitka. The room and the lamps and the people all faded before the girl with the parrot who looked and looked at him so strangely that his heart shivered. "Pretty Polly," she mocked, coaxing the parrot.

"He'll muss her in a minute," shrieked Mrs Farmer with infinite relish. "It's your bed-time, Mother," said Mildred. "Come along." Paddy took out his watch. "I'm going too, and so is Mitka." Mildred nodded. "I'll wake the old C. and toddle him off. Now, boys," she said to the two dark young gentlemen, "off with you. And leave your windows open." Valerie put back the parrot and dropped the check cloth. She stood smiling, her finger on her lips as though she were listening to something going on inside the cage until Mildred went up and put her arm round her. "Come up to my room and let's have a drink - the four of us," she said.

The rooms on the top floor of the house belonged to Mildred and 
Paddy. When the two brothers entered she was sitting on the side of the bed in a blue silk kimono embroidered in white wings. Valerie Brandon was beside her and they were smiling at each other. On a little table stood a bottle of wine and four glasses. "In honour of Mitka," said Mildred. "Open it, Paddy." For some silly reason Mitka felt shy. He could hardly bear to look at the two women and at the room which seemed so full of an unknown Mildred. Her slippers and her dress lay on a couch. A powder puff was on the table with the glasses, the big, soft bed was half turned down. "I'll tell you something," said Mildred. "Mitka feels shy. Don't you? You're rather frightened, aren't you, Mitka? You think we're improper."

"Don't tease him," said Paddy. "You're horrid tonight, Mildred."

"Am I?" said Mildred, and as he handed her a glass she put her fingers round his. "Am I really, Paddy?"

"Well - no - not really." and Mitka heard the strange laugh of content that Paddy had for his woman. By slow degrees and scarcely knowing why he avoided her and yet wanted to look, Mitka glanced at Valerie. She was looking at him again but now her eyes were changed. She only looked kind and sweet and gentle and she seemed to be saying "Don't be shy. We're only playing." She drank her wine in tiny sips, and he drank from his glass when she did and felt quite free and gay again.

Suddenly there was a sound of steps on the stairs. Someone whistled. "That's Evershed home," said Mildred lightly, looking at Valerie. The girl put down her glass.

"Bon soir, mes amis," she said.

"Who's Evershed?" asked Mitka.

\section{II}

When Mitka came down to breakfast next morning there was nobody in the dining room except Mildred and old Colonel Foster. The Colonel sat in the sunny window with a copy of the morning Post spread across his knees, but Mildred was just pouring out her tea.

"Hallo, you nice child to wait for me," she said.

"Why, has everybody gone?" asked Mitka.

"Yes, thank the Lord. Breakfast is a baleful time in this house. The boys have to be off to the office early and Paddy has to go to the city. Later Evershed wants things specially cooked \& -" she nodded in the direction of the window " - has to be fed with a spoon, nearly. I wait till they're gone \& then feed in peace. Help yourself, dear. Did you sleep alright?"

"Like tops," said Mitka.

"Good," said Mildred absently. She looked tired and pale. "Don't stare at me, my child," she said. "I always look a rag in the mornings. I loathe mornings - especially ones like these - indecently bright, when the sun changes into a housepainter."

Mitka looked at her anxiously. "I think you must be suffering from a nerve," he said. "Really, frankly, the morning is lovely, but you do not feel strong enough to dress yourself up in it like you do the night." 


\section{0/ Unbound Papers}

"What do you mean?"

"Like this," said Mitka. "When I see you at night I always think this woman she wears the night as though it were her covering. She smells of it and her eyes are full of it and her voice has a thrill ... you know how exciting the night is, and how unknown. That is how you look too. I told Paddy that in bed last night $\&$ he said yes - I was right. He said he had never lost that feeling of you too. Well," he shrugged his shoulders \& crinkled his eyes at her, "you ought to wear the daytime in the same way. You know I have an idea that women, beautiful women, are the spirits of nature in that way. I mean that nature reflects herself in them as she does in ponds or flowers."

As Mildred listened to him she laughed. "How absurd you are," said she, but grace flowed back in her gestures and her smile and she looked very sweetly at Mitka. "Mitka, tell me something."

"What?"

"Have you ever been in love?"

"This is no place for me," said a voice at the door and Valerie Brandon strolled to the table \& leaned her hands on it. "Good morning," said she, and leaning forward she kissed Mildred's hair.

"Good morning. How interesting you look in that white dress with the black lace shawl."

"Don't I" she said. "Like a Spanish waitress in a cafe chantant! Isn't it hot. Hot already." She sat down at the table and put her hands up to her cheeks. "Can I get you some breakfast?" said Mitka politely.

She shook her head. "No, I don't eat it. What on earth were you talking about, Mildred, with Mr -" she hesitated " - Mr Mitka over the toast and bacon - the difference between Love and passion, or should women be as free as men? I don't know what I didn't hear as I came in."

"No." Mildred pushed back her chair. "Got a cigarette, Mitka? Thank you. They smell delicious. They're the sort you had before."

"Give me one too," said Valerie and she took the case from Mildred.

"I was having a good look at him in the morning light," went on Mildred.

"And I thought there is really something awfully attractive about Mitka.

I mean, although he does look young in spite of the moustache, he looks as though extraordinary things might happen to him. Don't you think ..."

"I'm not sure," said Valerie, considering him seriously.

Mitka looked up at her \& smiled. "Ah," he said, "Mildred is pulling my leg again. She loves to tease me. Really her opinion is this is not a bad little fellow. I put up with him for a few days."

"I expect you're right," answered Valerie. "Here! What am I doing?

I'm pinching your cigarette case."

"Go and smoke up in the drawing room," said Mildred. "I must get all this cleared away. Go on both of you." She went to the door and called, "Hans, Hans."

"Madame," said the German waiter appearing from nowhere with a thick bandage round his neck. 
"What is the matter now?" said Mildred in a disgusted voice. "More boils again, Hans. Ugh! How dreadful you look."

"Come along," said Valerie.

"Ah, Madame, please to excuse," mumbled the German waiter.

"No I won't excuse you Hans. I'm sure it's because you don't wash."

She scolded him in a hard angry voice that Valerie and Mitka heard all the way up the stairs.

"No one could stand this room in the daytime," said Valerie. "Come on to the balcony." There she unfolded a canvas chair and lay back, one arm behind her head. Mitka sat on a little stool, smoking. They were quiet. Then Valerie spoke. "I like being with you," she said. "You make me feel so good. No, I'm not joking. I mean it quite seriously. You can't think" - she snapped off a geranium from the balcony rail and bit the stalk - "what a relief you are, how rare it is to see someone like you who isn't either false or - ugly."

Mitka opened his eyes very wide. "Are you really not making jokes?" he said. "No of course I'm not." She sounded quite cross, \& began to bite the head of the flower. "Why should I bother to? But if you only knew what the whole crowd of us was like - my heavens you'd welcome someone like yourself for a change. It's not that we're bad or wicked," she said, throwing away the geranium stalk, "but we're ever so dull - so out of the way of real life."

"What does that last mean?" asked Mitka softly.

"We're not alive," she said. "Ugh! What a houseful we are! What a crew! You can't imagine," she turned to Mitka again \& smiled, "how absurd you looked in the drawing room last night with Mrs Farmer \& the Colonel \& the 2 South Americans \& Mildred \& I. I shall never forget the way you ran in with your eyes dancing - nor the way you looked round \& said "How beautiful it is here'. I nearly screamed!"

"But," said Mitka in a puzzled voice, "what's the matter with the house? Isn't it like other houses?"

"Oh, I suppose so," she said. "Like heaps of others suppose. Yes, I'm sure it is. I can feel the dust of hundreds of them in the hem of my skirt."

"But why do you stay here if you hate it so," asked Mitka, more and more astonished.

"Ah,"Valerie laughed, that's quite a different story. Ask me another. Yes, why do I? I wonder - " and she got up out of her chair \& leant against the rail looking down at Mitka. "After all, it's rather an easy question. Why does anyone do anything. Because they can't help it, I suppose. You get caught in a wheel \& round \& round you go."

"I don't think that," said Mitka. "I don't believe in wheels. If you really look yourself in the open face and say what you want to do you can do it.

Otherwise, why not jump off the balcony? What's the good of anything else." "Do you really think that people can do what they like" asked Valerie slowly. "Oh dear, I'm afraid Mildred's right in calling you young. I believed it once \& acted on it, too. That really was funny." 


\section{2/ Unbound Papers}

Mitka said wisely, "That depends, doesn't it, on what you want to do." "No," she said, "there is only one thing. To get free \& to keep free. Oh well, she said, bitterly, I see myself doing it. But that's what I noticed about you, I think. You looked really \& truly free."

Mitka nodded. "That's quite true," he said. "Yes, I am."

"But supposing," she began, \& then stopped. "Oh dear, what's the good. What on earth am I talking like this for. It's such nonsense, such hopeless nonsense," she cried desperately. "There's old Mrs Farmer down there going tata in a bath chair. She's seen us. Wave your hand to the baby."

"Don't," cried Mitka in a troubled voice. "Please, please don't. You make me dreadfully sad." He took the ends of her scarf \& fingered them while he talked, his head bent. "I cannot bear to think of anyone being so dreadfully unhappy. Perhaps I am, as you say, young - a 'silly boy'- but I would do anything in my power to help you. Believe me - I would." If he had looked up he would have been amazed to see her face. There was such a strange mingling of relief and scorn and amusement painted upon it. But he did not look up.

"Then be my friend," she said in a low, reflecting voice. "I don't know why but immediately I saw you I wanted you for my friend. I knew that somehow or other you could help me infinitely - infinitely - \& that I - in a way - don't misunderstand me - had been waiting for your help. Be my friend, my -" her voice dropped, "- my secret friend. Will you?"

Ah God, what bliss is this! thought Mitka. At last someone is asking for the gift of my friendship. I who have never had a friend, who have never had anyone to wholly love. He took her hand kissed it eagerly, humbly. "I will be yours to my heart," he said.

III

"Val. Are you there. Can I come in?"

"Yes do. I'm manicuring. What's the time, Mildred."

"About half past three. Paddy's just rung up from the city. He wants me to go for a run into the country with him. He's hired a motor."

"Dear me, what extravagance," said Valerie putting a little dab of red on each nail.

"Isn't it, my dear. I think it's for Mitka chiefly. Will you make a fourth? We'll be back for dinner."

"Yes, I'd like to," said Valerie slowly.

"You \& Evershed aren't going out this evening are you" asked Mildred.

The girl shook her head. "No, not that I know of. Yes, I'd like to come.

What time?"

"Well, he's starting now. He'll be here in about half an hour, I suppose. You'd better get dressed. I know the hours it takes you. How frightfully hot it is still. You lucky little creature, I believe you've got the coolest room in the house." "Well I boiled in it last night," said Valerie \&, looking up from her polishing, she and Mildred burst out laughing.

"What do you think of Mitka" asked Mildred. "Here, lend me those things. I'll have a go at my hands while you get dressed." 
"He's a nice little boy," said Valerie lightly.

"Yes, isn't he. Paddy's devoted to him. He's amusing too - don't you think?"

"Yes, he is rather."

"You've made an extraordinary impression on him," said Mildred.

"I have? Oh rot!"

"My dear, it's perfectly true. I watched him at lunch today. He couldn't keep his eyes off you."

"You'll be pairing off the Colonel with your dear Mother next," said Valerie, powdering her neck and arms.

"Not a bad idea either. But I'm quite serious about Mitka. I'd tell you anything."

"Oh well, what does it matter. He'll be gone in five days. I'll draw him on,

I've half a mind to. What shall I wear. I never have a rag to put on.

I'm frightfully wild with Evershed."

"That's all very well," said Mildred. "But you're a fool to talk like that.

Where on earth would you be without Evershed? I don't say he is particularly fascinating but he's worth any amount of money \& he's mad about you and he's awfully decent - and talk about spoiling you! Don't you quarrel with your luck, my dear. Eversheds don't grow on trees."

"But Mildred I'm so bored bored bored! You know as well as I do I've never been in love with Evershed \& he knows it too. That's what keeps him so keen on me I suppose. But - perhaps it's the hot weather's brought things to a crisis with me. l'm seeking for a romantic passion..."

"And Mitka's to be sacrificed," said Mildred shrewdly.

"Merci Madame." Valerie made a little face. "Ie n'aime pas les petits bébés."

"I don't believe you. But you won't listen to me."

"Yes I will, darling." Valerie kissed Mildred very lightly on the eyelids.

"I always listen to you, especially when you wear that blue veil and look like

a Parisian madonna."

"Oh get along with you."

"Catch hold of his coat, Paddy. Don't let him stand on the seat," said Mildred. "Mitka, you ought to be ashamed of yourself. People will say you've never been in a motor before. Just look at him, Valerie."

Do what he would Mitka could not stop smiling. He did not mind Mildred teasing him. Nobody could upset his happiness. He sat very still beside Paddy. He felt rather than saw his friend opposite to him, her little gloved hands clasped in her lap. This wonderful change in a few hours, he thought. Who am I? Am I the same man who came here last night? I am not at all the same. I belong to someone - the woman who sits opposite to me has asked me to be her - her secret friend. Now when I am at sea I shall always have someone to talk to in my thoughts \& to look at the stars with me \& to share my sadness.

But I cannot be sad like that any more - I can have that precious lovely feeling. Wherever I go my friend is thinking perhaps of me, \& whenever I come back there is she to come to. I will come running up from my ship. One thing I must learn - how to make her happy. And then one day she will say, you did this for me Mitka. You gave me this joy. Yes Valerie, this will happen, believe 


\section{4/ Unbound Papers}

me it will. He said her name over so often in his heart that he felt certain she must hear. But she sat quiet, her eyes half closed, the faint breeze fluttering her long purple veil. Mildred, too, lay back, smiling, soothed by the air and the quick movement to sleepy delight.

"Don't they look lovely," said Mitka to Paddy.

Paddy nodded. "Yes, lovely." He leant across put his hand over Mildred's. "Are you happy Dredy" he said. I know why he does that, thought Mitka. $\mathrm{He}$ is longing for her to look at him a moment. And he was glad for his brother when Mildred pressed his hand \& smiled at him. They were in the country flying down the silvered dusty lanes, past fields \& fields of hay. The scent of it was in the air like honey. I feel a little drunk, thought Mitka. I wonder is this country really what I see? If so it is the most beautiful They drew up at some big iron gates.

"Where are we Paddy."

"It's a place to have tea."

Although he was really so brave and made long speeches to her in his heart and called her by her name, Mitka felt shy of his friend. She seemed to keep him away from her, to join with Mildred in teasing him like a little boy. Quite quite different to the girl of the morning. The afternoon might have been a failure if Mildred had not teased him so much.

"Now's your chance," she said, when tea was over. "Take Valerie away into the garden \& lose yourselves. You'll never get such a chance again - she's dying of sentiment."

"Very well," saidValerie. "Come along Mitka. We won't be long. We'll come back for you two here." And he was actually walking with her out of sight of the others down little paths with flowers on either side. They came to a lawn hedged round with holly. A tree covered with yellow flowers grew in one corner. Valerie walked over the grass \& sat down under the tree. "Wasn't I clever to take Mildred at her word," she said.

"Wonderfully." Mitka lay down beside her, his face propped in his hands. Flecks of sun \& shadow fell on her from the tree \& she took up some of the little bell-like flowers that had fallen in the grass \& poured them from one hand to the other.

"And now," said Mitka, "you will tell me all about you, won't you. You see, ever since this morning I keep having trembles facing only five days. That is like a clock in me - five days, five days, \& then I am gone. Well I must know a lot of you. I can't know enough in five days of a friend, can I?"

"Too much," she said, pouring the flowers through her fingers.

"Please not to laugh," said Mitka seriously.

She bit her lip \& glanced at him, sideways. "Well, what do you want me to tell you."

"All," he said eagerly. "As much as possible."

She shook her head. "You'll be sorry."

"No I won't. I can't be. I can only be glad. Oh, please begin - so little time."

Then she was silent \& let the flowers fall in her lap \& picked them up again

\& shut them in her hands. "There's nothing to tell you, Mitka," she said. 
His heart gave a great thud when she spoke his name. "First time you ever call me by my name is under this tree," he said, and he stared up into the bright branches of this yellow wonder. "Ah, but please please be good to me. Tell me about you."

"What do you want to know?" she said. "You ask me - and I promise to answer." He had to be satisfied with that.

When she had told him, \& she told him little enough and all toned down and made fair in the telling, he lay still in the grass \& did not look at her. Very slowly he felt his heart beat close to the ground. "And you hate him," he whispered.

"I can't bear him," Valerie shivered.

Mitka put out his hand \& stroked her little shoe. "Oh my poor friend, my poor friend," he said. "How terribly brave you are. But surely, surely," he said, "there's some place that you can get away."

She shook her head. "There isn't any. It's not possible. Don't you think if there had been I'd have thought of it by now?"

"To hold you in his power like that. My God!" cried Mitka sitting up \& clenching his fists. "What a devil this man must be."

She bent her head. "What makes it so terrible is that he - he -"

"Oh," said Mitka. "Yes, I understand. OhValerie - my friend. How am

I going to free you? How am I going to make you happy?"

She shook her head \& looked at him with her long grey eyes.

"How wonderful you are - how simply marvellous," said Mitka, "and you really are my friend."

"Really." She put a check on his eagerness. "But Mitka you must understand that I have to be careful. We must be secret friends. We mustn't let the world touch us. When you think I am changed \& cold you must realize that I have to be like that."

"Once you have explained," he said, "of course I shall never not understand you - and -" he smiled timidly. "Believe me dear friend, we will find out a way."

She brushed the petals off her lap \& stood up, looking away from him.

"And you don't - despise me," she said.

"I hold you," he said, "like God." They walked back slowly through the shadowy garden. "Is it peculiar in friendship," said Mitka, "for me to tell you how beautiful you are, to voice out loud the way you walk $\&$ lift your little head, then snile with your eyes \& - all those things?"

\section{IV}

On the following evening when Paddy went up to his room to dress for dinner he found his little brother sitting on the side of the bed - in the dark. As he switched on the light Mitka rolled over with his arm across his eyes. "What's up? What are you doing?" asked Paddy curiously. "Is something the matter, Mitka?"

"No," said a muffled voice. "Only the sudden light, Paddy. It makes me blink." But Paddy was not satisfied. He stooped down and picked up Mitka's 


\section{6/ Unbound Papers}

handerchief from the floor, raised his eyebrows as he felt it, and sat down beside him. It was like old times to come upon Mitka like that - like the days that Paddy never had time or desire to recall except when he saw his little brother. What a child he is, thought Paddy - \& Mitka, as though he had heard his words, said, "Yes Paddy, I'm not ashamed before you. I've been crying." He sat up \& caught hold of Paddy's arm. "But not because I am sad," he stammered. "No, that's not why. It's because I hate someone so - so fiercely. I have been crying with rage!"

"I thought you were going to say just the opposite," said Paddy. "I thought, Mitka, you were crying because you were in love. Sure not?"

"Oh no," said Mitka - his lips quivering - "not a bit - not in the way you mean. I couldn't be. No, I've been crying in despair, Paddy, in such awful rage. Ah" - he put up his hands \& clutched his head - "terrible, terrible!"

"You won't tell me who it is you hate" \& Paddy added to himself: of course I know.

"No," Mitka shook his head. "I can't do that. Don't ask me. But Paddy - the sweet and the bitter are such an awful mixture in Life, aren't they? I almost think it would be better if you couldn't have both at the same time - if you had all bitter or all sweet. It would be much more bearable - \& juster, I think. Yes really." He looked up at Paddy through his tumbled black hair. "It's so impossible," he said, "to be torn by your head \& your feet at the same time you can't move either way. Tonight," he said, "I don't think God is cruel or merciful or loving - I think he's really silly, Paddy, \& a silly God is a horrible one to have. I would like to throw up my hands at him and say what an old fool you are - you imbecile! I suppose you - never - feel like that!"

Paddy shook his head. "Never, Mitka. I'm too hard. I'm too busy thinking about myself to worry over God. You see, little brother," said Paddy, \& he put his arm round Mitka's shoulders, "you're really in an unfortunate position you've never grown a shell. Now to be able to go through Life you've got to have one, and a thick one too. Everything that touches you makes a mark hurts you - or delights you, and as Life isn't all sweet as you say you're bound to be hurt as well as delighted. Now I'm nearly all shell, Mitka. I couldn't keep open heart for the world like you do. I want to be powerful - that is, rich and loved by one woman - and I just fight for those two things on the quiet \& keep myself guarded against everything that can get in the way of them. So Life's pretty simple for me. But for you," he said, "oh Mitka, you're like a naked baby on a battlefield."

Mitka rubbed his cheek on Paddy's sleeve. "No," he said, "you're not quite right. I'll tell you how it is with me. All my life, ever since I can remember, Paddy, I've had what you call a shell - it's been loneliness. Things have hurt and delighted me, that's true, but never really badly because I've not been near them. I've kept quite by myself - lonely, Paddy. Then you see, the life I chose to go to sea - I chose because it expressed my lonely feelings better than any other. Not that I didn't hate and loathe this thing that covered me up - in a way I did. But in another way, if you can understand me, it was the most precious thing I could have. You know, although I've known such a lot of 
people I've never had any friends because - except for laughing \& joking and being on acquaintance terms - I can't understand people, properly. People are too complicated for me \& I don't feel at all complicated. I feel - just one thing or another thing as I used to when I was a little boy, that's all." "And now," said Paddy, "you're not lonely any more, is that it?" "In a way - yes, I suppose so." "And you hate the person who's done this to you?"

"Oh my God no," said Mitka quickly. "How could I? No, no, it's not that." "Oh Mitka," laughed Paddy, "if I sit here any longer with you a long white beard will flow over my chest. You make me feel hundreds of years old. I think I'd better shut you up in a box \& take you back to your ship again."

\section{$\mathrm{V}$}

And then came Sunday. Mitka remembered the Sundays at Wyndham Square the untidy idle morning, and then the great dinner at half past one with everybody at the table and then the sleepy hush that fell on the house till tea time. He used to think it a very amusing day. But somehow that Sunday was not today. The dinner was the same, from half past one to half past two - they sat at the long clean table while the German waiter, white \& sweating, handed the steaming food. Old Mrs Farmer in a high white cap with a coloured silk butterfly on it pecked at her food just as she used to. The Colonel's shaking hands, the whispering of the South American boys, \& Mildred's clear ringing laughter jarred his nerves. What is the matter with me he thought. Why is it all so ugly. And Valerie Brandon sat, proud and mocking by Evershed's side. Mildred would not leave him alone.

"Oh Mitka, you do make me laugh today. I can't keep a serious face when I look at you. What's the matter Paddy, have you been scolding him."

Paddy would not stop her. "Mitka your face is as long as - a double bass. Isn't it, Evershed."

"He is in love," cackled old Mrs Farmer, spilling custard down her black silk bodice. "That's the only reason young people get the dumps."

"Clever mother," mocked Mildred. "Look what a piggy mess you're making of yourself, too."

"You wait," said old Mrs Farmer. It was her everlasting retort. "Just you wait." It was her only defence and she seemed to scent a triumph in it. She munched it over and over in her old mouth - "You wait. Just wait, my lady, that's all." Is this going on for ever, thought Mitka desperately. But it was over at last, and by and by as on those former amusing Sundays the house grew quiet. What am I going to do now? He went up to Paddy's room but Mildred was there. He peeped into the drawing room - the old people were going to sleep - and on the balcony Evershed and the South American boys were reading out bits from the Sunday papers. There is no place for me, thought Mitka. His heart said, "Where is she, where is Valerie?" Yes, he was miserable, and tired too. He wanted to lean up against things. I'd like to sit on these stairs with my head against the wall, he thought. Then I could be sure of ...

He heard her door open and the soft rustle of her silk skirts. She came down the stairs with a pink parasol \& a book in her hands. 


\section{8/ Unbound Papers}

"What are you doing," she said.

"I'm not quite certain."

"I'm going into the Square to read. Would you like to come." And so they walked out of the house in the hot afternoon sun into the Square. Valerie sat down on a little green bench shaded with her pink parasol. "You haven't got a hat," she said. "Isn't it too hot."

"Oh no, not for me," said Mitka, screwing up his eyes at the sun. "I have a very thick head."

She smiled at him. "You do say funny things."

"Do I" he said anxiously. "You mean silly things."

"No, no, no. I mean funny - and charming - things. I shouldn't like you to talk any other way ... What was the matter with you at dinner today?"

"Ah," began Mitka. "Let me think back. It's such a long way away now, I've forgotten it ... Yes, I remember. I don't know. I felt just miserable."

"But why," she insisted, "why."

"I think perhaps a little piece of your hatred of the house dropped in my heart. And at the same time - there was something else."

"What," said her low kind voice. "Tell me Mitka."

"I'm such a disgusting doubter," he said. "Ever since we walked in that garden I have wanted to ask you again - are you still my friend. You haven't changed? I know you haven't. I hate myself for wanting to hear - \& yet when I see you with other people - though I understand why you must be different, I get a sort of fright all the same, \& I think: She has forgotten you. It was all a dream! And then I feel I must run to you and ask you \& beg you to say it over \& over, 'No, not changed - just the same - I am your friend, Mitka.' I won't always be such a fool," said Mitka. "But perhaps it is the newness that makes it so awfully sweet and terrible at the same time. Please don't be offended with me."

"I'm not," she said. "But Mitka -" (what a heavenly name I have, he thought) "- you are content with my friendship, aren't you. I mean if I felt I had made you sad -"

"Oh my God, no. Oh Valerie - if only I could tell you - how all life is changed for ever." She did not seem quite content with his answer. She frowned a little $\&$ half shut her eyes as though she were puzzled a little. "But here's another thing," he said, not noticing. "I'm terrified when I think of the letters I want to write to you - you will write to me, often, often."

"Often," she promised, shortly.

"You'll really tell me things."

"Of course I shall."

He moved restlessly. "I go on Tuesday - on Tuesday morning," said Mitka.

"For how long," she asked absently, fingering her rings.

"For - you lied," cried Mitka, catching sight of her drawn brows. "You're tired, Valerie."

"Yes, I believe I am a little. It's the sun." And Mitka had a sudden vision of himself as an immense giant pulling it out of the sky and smashing it because it shone too warmly on Valerie. 
That evening was like the first evening. They were all in the drawing room - except Evershed - \&Valerie was at the piano again. But Mitka sat alone in a corner and watched, tired \& happy. Sometimes as she played she looked across at him. "I am your friend," said her grey eyes - until Evershed came into the drawing room \& leant over the piano talking to her in a low voice. Her head was bent. Mitka heard her voice, then saw her look up \& smile at Evershed \& shrug her shoulders. From his corner Mitka watched the two. All this is nothing, he said to himself. She is your friend. She told you so today. All this does not matter - not at all really. It's nothing to do with you and with her. You are going away on Tuesday \& then you need not ever see her with other people. Your thoughts can be quite alone with her. He scolded \& comforted his heart, but all to no purpose. His heart began to cry and cry and then to sink in despair in his little shaking body.

\section{VI}

"And so you're going to leave us today," said Mildred. "I don't think you're a very nice boy, Mitka. What were you doing all yesterday. You must have gone out after breakfast - \& when did you come in."

"I walked," said Mitka. "I came to a sudden conclusion early in the morning \& walked all over London."

"What on earth for?"

"To see it. It isn't anything though. Old webs with no spiders," he said, smiling at her.

"Oh well," said Mildred, "a Mother's blessing. Run along. I must dress.

I shan't see you again, shall I?" She had been having breakfast in bed \& she had called to Mitka to come \& say goodbye.

"No, I suppose not."

"Run along and say goodbye to your little sweetheart," said Mildred.

He had packed his leather bag. He took it downstairs put it in the hall $\&$ then went up again to the drawing room. He knew Valerie would be there. She sat on the sofa with her hands in her lap. The blinds were down \& the drawing room was very cool \& dark. Mitka shut the door \& went up to her \& stood like a little boy about to say a lesson.

"So you're going," said Valerie.

"Aren't you going to ask me what I did all yesterday" he said in a husky voice. "Well, I tell you. I made up my mind to say to you: no, please don't write me letters. No, please take back this friendship. I don't want it. I am very sorry." Valerie opened her eyes at him. "Why," she whispered, watching him keenly, with a sort of delighted surprise waking in her face.

"Because -" he shrugged his shoulders "- I haven't a reason," he said in a low voice. "I haven't a reason at all - except I am not what you thought I was really, and I am a fraud."

"Mitka."

He went over to the piano \& leant against it away from her.

"Mitka, if you've changed \& you don't want me any longer - if I'm to lose my 


\section{0/ Unbound Papers}

friend," she said, "well," she gave a little breathless laugh, "I can't help that, can I - I can't plead for you, can I, Mitka. But I do think that I've got the right to know why - you are - breaking our secret."

He shook his head quickly. "no - I can't tell you. No good asking. The thing to do," he said, speaking slowly, "is for me to say my goodbye and then to go. Goodbye, just like that. Not turn." He turned and looked at her \& the words died on his lips. She sat very quiet, her eyes upon him. He could see her little breast rising and falling $\&$ he could see her hands half hidden in the black lace shawl. Slowly she seemed to grow and fill the world as he watched her. What did anything else matter. What was anything? Nothing but her remained. "It's no good," he cried sharply. "I can't. I can't tell you," \& he stumbled forward \& sat beside [her] \& put his head in her lap. "I love you, love you, love - "

"Ah," she breathed - in the mirror opposite she smiled at the radiant lovely face that smiled at her, \& then she bent over Mitka and laid her hand lightly, lightly on his dark head. "Mitka, are you sure?"

He raised his head and looked up at her, frightened and desperate. His eyes were full of tears and his mouth was set hard. He could not speak - only nod his head; his breath came in shaking sobs.

"Don't," she said tenderly. With infinite gentleness and sweetness she looked at Mitka. "I love you too," whispered Valerie.

"What is that you have said" he stammered. "Say it again. Quickly, quickly." "I love you too."

He seized her hands and kissed them over and over, the backs of her hands, the palms of her hands - each little finger, never taking his eyes off her face. He said in awe \& wonder, "You love me," and again, holding her hand against his heart, "You love me!"

She nodded. Smiles flew over her lips. How radiant she was, and yet there was a kind of tired languor in her gestures and her voice. "Oh, for a long time. Didn't you ... really know?"

"If God had appeared to me \& told me I should not have believed him. How could I believe that this world could hold such a heaven." He gave a queer run-away laugh. "I'm not dreaming, am I? This is I, Mitka, \& you are Valerie - and you have said you love me." Suddenly he put his arms around her. She leaned to him and they kissed each other. In that long kiss Mitka gave himself and his brave love and his hopes and all his being into the keeping of Valerie. "Forgive me," he said. "Forgive me."

"Why" she whispered, looking at him in ecstasy - \& yet she was calm \& he trembled violently.

"I am so unworthy \& I am so weak. I can hardly bear my joy. What have I done to be this happy man. Ah!" he cried, "how beautiful you are, my love how marvellously beautiful - there's a light shining from every little finger in you like the light from a saint. Valerie, Valerie." She lay among the cushions and smiled at him. He bent over her. "And you will be my wife."

Came a tiny pause - long enough for a throb of surprise in Valerie's bosom. Then she said, "Yes, your wife, Mitka." 
He made as if to kiss her again then he drew away \& clasped his hands together. "No, no!" he said in a strained voice. "Don't let me. Help me, Valerie. Don't let me kiss you too much. If I do I shall go mad and I shall not be able to leave you - and we have to part now. Yes yes we must - if only to come together again, dearest. I must leave you soon."

"So soon as that?" she whispered - and she put her arms round him \& drew him to her and pressed his head on her breast. "Forget everything," she whispered, "everything except that we love each other my dearest, my dearest."

He broke away from her arms. "That's just what I can't do," he stammered. "Don't you understand." And he got up \& walked quickly up and down the room. "I am lost if I do that. You see this sudden joy, and you, so sweet to me, \& my thoughts on fire, and all the future to be settled in just this breath of time - suddenly, you understand. My angel," said Mitka, "my beloved soul, I have to leave you, and we must wait for our caresses and for our happiness until I come back quickly, as quickly as I can, \& take you away \& we are married. Now," he said, "we have to decide everything, to make our plans." He stopped in front of her \& took her hands \& began kissing them again. "Already, Valerie, my head is full of plans. I can even see our house already, and our child." She sat quite still with her head bent. "Listen to me, my darling - " and he began to talk and to arrange \& plot and settle these marvellous happenings. He was going now to Alexandria to get money. Then he would go to Marseilles. He had friends there. He could get something to do in Marseilles. In the meantime he would borrow enough money for them both \& she would come to him there. That was the best. They would start a new life together, far away from everybody, from everything. Now Evershed \& his threats did not matter. Nothing \& nobody could touch or harm them.

Life unfolded like a sweet flower as he spoke. He smelled its fragrance, he leaned over it and the dazzling miracle of its beauty \& colour intoxicated him - he spoke on and on, for years it seemed to the listening Valerie - who never moved or looked up, whose hands lay in his without warmth or pressure. Just once when he knelt by her and said "Ah Valerie, our life together, our children" a little smile crooked her lips \& she raised her eyebrows faintly. Otherwise she gave no sign.

\section{VII}

One morning a few weeks later Mildred walked into Valerie's room. The young girl was in bed and asleep. Mildred stood looking down upon her and wondering in a vague way how or why Valerie kept her childishness of appearance. She lay on her back; the sleeves of her nightgown had fallen back leaving her arms bare to the shoulders. Long curls of black hair lay on either side of her cheeks, her eyelashes and brows cast a faint shadow, her lips were parted to her gentle breathing. Yes, she's lovely! thought Mildred. Good Lord how innocent she looks. I expect she's as passionate a little devil as they make them. Mildred drew the curtains from the window butValerie did not stir. 


\section{2/ Unbound Papers}

On the dressing table lay her scarf, long white gloves, a fan, and a big bunch of bruised yellow roses. The room was littered and disordered with her clothes and toilet jars, but Mildred realized this untidiness as something careless and fascinating, a part of Valerie. Yes, if I were a man I'd be in love with this little minx, too. She's so certain of herself and so utterly careless, and yet she keeps her secret. Yes, she's cold and passionate. With her thumb and finger Mildred flicked the envelope she held in her hand, glanced at the writing and postage mark, and made a little grimace. Valerie sighed, flung out her arms, half rolled over and sat up, shaking her head.

"I'm not at all awake yet," she said in a clear unreal voice (children who talk in their sleep speak so).

"Well, its high time you were," said Mildred. "Its after eleven o'clock. There's a letter for you," and she gave it to Valerie.

"You're an angel," said Valerie, just glancing at the letter. "We didn't get in until four. Went to one of those idiotic clubs." She smiled. "Ah, come and sit down a tiny minute by me," she coaxed. Mildred sat down and Valerie put her arms round her.

"So its still going on, is it?" asked Mildred, running her finger up one of Valerie's curls.

"What? You mean these pathetic effusions?" said Valerie.

"Mm. I was in your room the other day when the housemaid was turning it round \& she pulled dozens from behind the white paper frill of the fireplace. I knew they were from the same - the poor child uses such funny paper. Do you read them?"

But Valerie did not answer. Instead she said, "Well what am I to do? I can't stop him. I've written and told him its hopeless until I'm tired. Its all very well for you to laugh, but its boring - and so stupid. There's something humiliating in a boy's letters. Gaucherie can be rather delightful when you're with a person - charming eyes, a baby mouth, silky hair can carry it off. But by letter - oh dear no. What are you laughing at."

"You. I am laughing at you troubling to play for me. I know perfectly well you're up to some game with Mitka. I'd love to know what it is. He's a queer little creature. I am sure that if you had told him to stop writing he wouldn't write. He's too proud \& too sensitive to do that. Well I don't believe you've told him. But then you're not in love with him, so why keep him on the hop?"

Valerie lay down in bed, threw the letter up in the air and caught it again. "Bother me," she said lightly, "I don't know. But if once I've touched a thing I can't let it go until l've tried to break it or to see if it can break me. Its my one principle - snatched from a weary world - "Then she sat up $\&$ tore open the letter. The envelope slipped off the sheet on to the floor. There were pages \& pages of fine careful writing. "Like to hear?" she said, making a face at Mildred. But Mildred moved away from the bed.

"No, no. I loathe hearing things being killed - \& babies cry worse than pigs. Bon appétit, you little witch." She drifted out of the room. 


\section{Dearest of all}

Do not be frightened. I am writing to you in my bed. I have caught a fever of some kind on the top of some pleurisy and therefore I am not well. Excuse my stupidity. What a fool I am. I believe it was anxiousness. It is so long since I have had a letter from you \& the waiting and thinking from the first to hear has made me a little tired. There have been so many things to do and I am not the man of affairs that Paddy is. But people have been angels. That is because I love you. I have carried you in my heart wherever I went \& I do not believe a person has seen me - it is you they have seen in my looks, and it is for you they have been kind. As I told you last week, my father has sent me the money. Everything is ready \& waiting for you. I am staying here until you come $\&$ we find where you should wish to live. Of course where I am now would not do for you, but for me it is all right, and it saves me money. Besides, everywhere is heaven with you in my heart. In the first days of my illness the room was so full of you I stretched out my arms to it like a child does to a garden. I know there is a good reason why you don't write. I know I must not try you - \& you are wise - but still I am so stupid, every time the postman sounds in the street I rush to the staircase \& my heart beats up. Lying here among all other steps I know his now. Even if I lie asleep my heart hears them and wakes me \& I run out of bed. Come, my darling. Everything waits for you. Come soon. It will not be hard. I know you are very delicate \& fine, but do not be afraid. Such foolishness to write but my head burns. Valerie, Valerie. I kiss your little feet. I implore them to bring you quickly to me. I adore you.

However, I shall burn it, she thought. She got out of bed \& dropped this letter too behind the white paper frill in the fireplace. Yes, she was really curious, and the idea of Marseilles was exciting, decidedly. Of course she had never meant to go. Not really, but just for a time. And she saw herself in a white room overlooking a garden of pink waxy flowers that reached down to the sea. Mitka was with her, lying on his back with his eyes closed, very flushed, his ears \& lips very pink. Yes, he'd look just like that. He'd be an awfully charming lover - after my commercial bulldog. But you couldn't live up to [it], my child, she said, staring at herself in the glass. Because, you see, my lady, that's what's the matter with you. Her lips smiled gaily, but her eyes said Yes, that is true you're too clever to be found out, but you'd kill him, you know you would and oh what complications! But Marseilles. Well - and maybe I can buy white carnations from a dark musky-smelling flower seller who could not keep his eyes off her whiteness. You're a perfect little thing being loving to this boy, she scolded herself, or you're degenerating - choose which one you like the better. I am sure he has [...]

\section{VIII}

Again he heard the sound of those footsteps. Again he rushed to the door, opened it and hung over the iron stair rail. They were coming up the stairs, 


\section{4/ Unbound Papers}

they were quite near. Again he made that tremendous effort to speak above the throbbing of his heart. "Anything for me?" Oh my God - what had happened? The postman looked up at him, grinned, came up further, dipped into his satchel and Mitka bent and took the letter through the bars.

"V'là M'sieu'," said the postman, passing the letter into the trembling hands as though it were bread he carried.

But Mitka did not answer. He straightened up \& holding the stair rail he went slowly, slowly back into his room, shut the door, leant against it, the letter pressed to his heart. There was a piece of mirror on the wall opposite the door. As he raised his eyes he saw himself reflected in it, so transfigured, so mysteriously joyful. Mitka is dead, he thought. Mitka is a saint. For a long time he stood there. And a strange thing happened. He forgot all about the letter that lay on his heart. With wondering eyes he looked at his little room. A funny little room under the roof of a huge building. In one corner stood a bed covered with a red quilt patterned with yellow flowers. In another an iron wash-stand. A table stood in the middle with a chair pushed against it. His luggage was piled against a wall. On a shelf by the bed there were bottles bottles of all colours. A pencil ray of sun shining on these bottles made them wonderfully beautiful. Over the window hung a battered blind but it did not keep the sun out. The sun shone in rays and big soft spots of gold light on the floor \& walls. Tenderly, he smiled at the room and walked to the table \& sat down by it. Yes, I lived here, said Mitka. He tapped with the letter on the dusty table. It's rather nice, he said dreamily. The blind lifted and tapped to a little breeze. Through the window there came the sound of long-drawn cries and lazy shouting. AAAI drawled a voice, and then EEEEEE - just the same sound their old gardener made with his tongue when he chased a swarm of bees. AAAI came in lazy shouts - and then the old gardener answered, angry and bustling. He wanted very much to get up from his chair and look out of the window but no, his body would not move. It was no use trying. He sat still. He felt very peaceful, almost as if he were at sea again. Yes, his little room with the spots of sun and beautiful bottles floated in the sea, and those were the voices of sailors. Why do I feel so frail? Yes, I know. It is because I have not been to sleep such a long time - and at the thought he began to breathe slowly but not too profoundly because a deep breath moved a knife that had fallen into the bottom of his lung. But it was good even to breathe like that. How long was it since he had been to sleep? Well, he could not remember. Perhaps he had not been to sleep for years. Now he could move. He got up from the table and lifted his arms above his head, and walking carefully so as not to step upon the quivering spots of lovely light that danced on the floor he reached the bed and lay down, pressing his head into the pillow. Away floated Mitka in the room in the roof. Away he floated. AAAA-iiii came fainter \& fainter now and the sun danced on Valerie's letter.

That was how she found him. An African servant with a slop pail had met her at the bottom of the stairs, had struggled in front of her up the five flights, the stinking pail still in her hand. Valerie opened the door \& came in quite quietly. But when she saw Mitka lying on the bed she ran over to him - 
terribly frightened for a moment. No - nothing like that had happened. He was only sound asleep, his face covered with beads of sweat, lying on his back, his lips and his ears very pink. Had she dreamed this. But not this disgusting dreadful room, not this vile house, that awful African woman, the smells. So this was where he expected her to come - it was to this place. She looked at the flowers she carried - white carnations bought from a muskysmelling flower seller. She held them to her face. She saw the red \& blue bottles, the ugly blobs of sun spilling through the broken blind - and then she saw on the dusty table her unopened letter to him. Her presence of mind never deserted her a moment. Deliberately \& making no attempt to hush her steps she walked across to the table, picked up her letter. She even took care to see the petals of her flowers had fallen. I loathe the cheap properties of tragedy, thought Valerie, shutting the door after her.

\section{IX}

Evershed was waiting in the room of the hotel, striding up \& down, his face dark red, his eyes immense \& glazed. When she opened the door he started violently. "Where in God's hell have you been" said Evershed. "You've given me a pretty turn. Here I go out for a jiffy to get some cigarettes \& come back to find this - this bloody little note Back in an hour's time. Look here, Valerie, you can't do that sort of thing you know. It's - it's not cricket. It's - it's a damnable trick to play on a man." He was trembling all over \& wiping his eyelids \& his moustache with a folded handkerchief. "What did you do it for? Why didn't you tell me? Did you want to buy something? What was it?" She looked at him in amazement, a childish smile on her lips. "You poor old boy, I never dreamed you'd feel like that. I merely thought while you were away I'd like to go for a walk after that train. I'd got a headache. And I felt cross. I wanted air \& I wanted to walk off my black monkey. Did I really give you a fright." She put up her hands to untie her veil. "You're joking." "Joking!" He gave a great sigh of relief \& flopped on to the bed. "I never thought a man could be such a fool about a woman. I nearly howled. I was half mad, Valerie. Everything you could imagine rushed into my brain. Why, I thought you'd done it on purpose. Brought me here and then skeedaddled - no not quite as bad as that, but I - well it's no good going over it again. Was that really all. You weren't chippy with me or anything. I thought you seemed a bit quiet in the train. Thunder!" said Evershed, "that was a nasty scare."

"On the contrary," said Valerie. She had taken off her hat. She lifted her hair off her face \& went over to him \& perched on his knee looking up at him with a strange wistful smile. She put her hands on his hot cheeks. "I believe I'm really falling in love with you," she whispered.

"Valerie, my Queen," said Evershed. "I knew you'd come round, little girl." 